\title{
VIOLÊNCIA SEXUAL CONTRA CRIANÇAS E ADOLESCENTES MEDIADA PELA TECNOLOGIA DA INFORMAÇÃO E COMUNICAÇÃO: ELEMENTOS PARA A PREVENÇÃO VITIMAL
}

Tese apresentada à Banca Examinadora da Faculdade de Direito da Universidade de São Paulo, como exigência parcial para obtenção do título de Doutorado em Direito, sob a orientação do Professor Associado Alvino Augusto de Sá.

Faculdade de Direito da Universidade de São Paulo

São Paulo - 2012 
VIOLÊNCIA SEXUAL CONTRA CRIANÇAS E ADOLESCENTES MEDIADA PELA TECNOLOGIA DA INFORMAÇÃO E COMUNICAÇÃO: ELEMENTOS PARA A PREVENÇÃO VITIMAL

MARIA EMILIA ACCIOLI NOBRE BRETAN

DATA $/ 2012$

BANCA EXAMINADORA

$1^{\circ}$ Examinador(a)

Orientador Professor Associado Alvino Augusto de Sá

$2^{\circ}$ Examinador(a)

$3^{\circ}$ Examinador(a)

$4^{\circ}$ Examinador(a)

$5^{\circ}$ Examinador(a) 
El viento

Cuatro años cumplía Diego López y aquella mañana le brincaba en el pecho la alegría, la alegría era una pulga saltando sobre una rana saltando sobre un canguro saltando sobre un resorte, mientras las calles volaban al viento y el viento batía las ventanas. Y Diego abrazó a su abuela Gloria y en secreto, al oído, le ordenó:

- Vamos a entrar en el viento.

Y la arrancó de la casa.

(Eduardo Galeano. Bocas del Tiempo, 2004.) 
Às crianças e aos adolescentes.

(Que tenhamos a coragem de segurar em suas mãos; e que,

compartilhando de sua alegria,

possamos, juntos, entrar no vento!) 


\section{AGRADECIMENTOS}

Uma tese não se faz sozinha. Uma tese não se faz sozinho.

Quero agradecer às inúmeras pessoas que fazem parte de tantas partes da minha vida, e sem as quais este trabalho jamais seria possível. Aproveito para falar um pouquinho delas, e delas comigo, aqui:

Aos meus pais, Isaura e Onivaldo: só o que posso esperar é ser digna de todo o amor e de tudo de melhor que me dedicaram, ensinaram, demonstraram, fizeram. Obrigada, por tudo, sempre.

Ao meu irmão, Pedro(linus), obrigada pelo apoio, por sua amizade e pelo exemplo de perseverança que você é, para mim.

Vanessa Agapejev, Mario Rui, Fabiana Coimbra (Bibs), Silvia Losacco, Anita Gabriela, Bruno Shimizu, Mari Chammas, Dani Costa, Fernanda (Cranci), Paulo Ferraz, Natália Fujita, Dimitri Brandi: é um privilégio enorme ter vocês na minha vida. Não tenho palavras para agradecer a amizade e o apoio de vocês.

Aos amigos e amigas com quem compartilho ambientes e interesses diversos, meu agradecimento pelas horas sempre deliciosas de conversas e aprendizados, e por todas as broncas que me deram pela minha ausência. Com isso, me fazem perceber o quanto eu sou querida.

Aos colegas da pós-graduação, co-orientandos, e coordenadores do GDUCC/GETCrim, o meu agradecimento por manterem viva a prática interventiva no cárcere e por compartilharem, comigo, as angústias e delícias da vida acadêmica.

Aos docentes e estudantes da FACAMP, agradeço o constante exercício prático da dialética, e a energia compartilhada ao longo desses 4 anos.

Suzanne, Chris, Michéal, Taryn, Rebeccah, Vanessa, Renee e Nancy, do IICRD: obrigada por confiarem em mim! Compartilhar sonhos e ideais com vocês é um privilégio pelo qual sou grata a cada dia! 
(Suzanne, Chris, Michéal, Taryn, Rebeccah, Vanessa, Renee and Nancy, from IICRD: thank you for trusting in me! I'm privileged to share dreams and ideals with you, and for that I'm grateful each and every day!)

Ao Benedito dos Santos, minha profunda admiração e agradecimento pela oportunidade de trabalho conjunto e aprendizado na CPP; à Patrícia Guisordi, sou grata pela energia contagiante e pelo apoio imprescindível na coordenação.

A todos os parceiros e parceiras da CPP com quem tive a oportunidade de conviver, em especial às crianças e adolescentes envolvidos no projeto, obrigada por me ensinarem, sempre, e por compartilharem comigo o sonho de um mundo mais justo.

Pelo balanço de corpo e de alma, e pela sensibilidade, força, leveza e beleza que espalham pelo mundo, sou profundamente grata ao Pedro Prado e à Andrea Prior.

Às amigas e amigos do Espaço Rasa: compartilhar a energia do Odissi com vocês é muito especial!

Aos amigos e amigas que compartilham comigo redes sociais e fóruns on-line, agradeço as palavras de incentivo nos momentos difíceis e a companhia durante dias e noites na frente da telinha. A rede pode ser virtual, mas o apoio que me deram foi muito real.

À Fabiana Coimbra, à Alessandra Coelho, ao Ivan Carotti e ao Roberto Júnior deixo um agradecimento especial pela ajuda em diversos momentos desta jornada. Eu não teria conseguido sem o apoio e a amizade de vocês. Obrigada!

À Dinah Borges e à Silvia Losacco agradeço a leitura atenta do trabalho, e as importantes considerações e alertas que me fizeram.

Ao Daniel Aurélio sou profundamente grata pelo apoio fundamental durante todo o processo, pela leitura crítica da pesquisa e pelas inúmeras e estimulantes trocas de ideias, que começaram mesmo antes do início da redação, e que me obrigaram, constantemente, a refletir sobre o caminho percorrido.

À Viviane Fontoura e ao sonhalista Paulo Lima, minha gratidão pela revisão das traduções do resumo! 
Aos Professores Martha de Toledo Machado e Sérgio Salomão Shecaira: agradeço o necessário e preciso olhar crítico durante a qualificação e as preciosas sugestões para a elaboração desta pesquisa.

Deixo para o final, não por ser menos importante, mas exatamente pelo contrário, o agradecimento ao meu orientador, Professor Alvino Augusto de Sá. Antes de tudo, sou-lhe grata por ter-me recebido com generosidade no programa de pós-graduação (e lá se vão 7 anos!), talvez sem ter a dimensão da importância que tal gesto teve na minha vida, naquele momento e dali por diante. Também agradeço a paciência e os puxões de orelha durante a cuidadosa orientação! Obrigada, Professor, pelo privilégio de desfrutar de sua convivência e de absorver um pouco de sua sabedoria, acumulada em uma instigante e inspiradora vivência da teoria e da prática. Obrigada por se permitir (e, com isso, nos permitir) a reinvenção, com a humildade de quem tem curiosidade científica e profundas convicções mas, ao mesmo tempo, sabe que é possível e necessário mudar. 


\section{LISTA DE SIGLAS E ABREVIATURAS}

ABMP - Associação Brasileira de Magistrados, Promotores de Justiça e Defensores Públicos da Infância e Juventude

AIC - Instituto Australiano de Criminologia (Australian Institute of Criminology)

ANCED - Associação Nacional dos Centros de Defesa da Criança e do Adolescente

CEDECA - Centro de Defesa de Direitos da Criança e do Adolescente

CF 88 - Constituição da República Federativa do Brasil de 1988

CGI - Comitê Gestor da Internet no Brasil

CIDC - Convenção Internacional sobre os Direitos da Criança

CONANDA - Conselho Nacional dos Direitos da Criança e do Adolescente

CPP - Parceria para a Proteção da Criança e do Adolescente (Child Protection Partnership)

ECA - Estatuto da Criança e do Adolescente (Lei no 8.069, de 13 de Julho de 1990)

GDUCC - Grupo de Diálogo Universidade, Cárcere e Comunidade

GETCrim - Grupo de Estudos sobre Temas de Criminologia

IBCCrim - Instituto Brasileiro de Ciências Criminais

IICRD - Instituto Internacional para os Direitos e Desenvolvimento da Criança e do Adolescente (International Institute for Child Rights and Development)

NCA - Núcleo de Estudos e Pesquisas sobre a Criança e o Adolescente do Programa de Pós-Graduação em Serviço Social da PUC/SP

ONG - Organização Não Governamental

ONU - Organização das Nações Unidas

PUC/SP - Pontifícia Universidade Católica de São Paulo

PNUD - Programa das Nações Unidas para o Desenvolvimento

SGD - Sistema de Garantia de Direitos da Criança e do Adolescente

SINASE - Sistema Nacional Sócio Educativo

TIC - Tecnologia da Informação e Comunicação

UNESCO - Organização das Nações Unidas para a Educação, a Ciência e a Cultura

UNICEF - Fundo das Nações Unidas para a Infância

USP - Universidade de São Paulo 


\section{RESUMO}

A Tecnologia da Informação e Comunicação (TIC) é parte elementar da revolução tecnológica sem precedentes que caracteriza a "sociedade em rede" (Castells) e que vem acompanhada de transformações sociais, culturais e econômicas em diversos níveis. Ao mesmo tempo em que apresenta inegáveis benefícios, como a comunicação sem fronteiras, a revolução tecnológica nos coloca desafios também globais. Dentre esses, se encontra a violência sexual contra crianças e adolescentes, multifacetada, global e interconectada. Com o uso da TIC cada vez mais disseminado dentre as crianças e adolescentes brasileiras, os riscos de aliciamento e abuso sexual on-line, agrupados na pesquisa na categoria de violência sexual mediada pela TIC, atingem a todas; porém, crianças e adolescentes pertencentes às classes sociais mais baixas são as mais vulneráveis. Aos riscos reais somam-se a sensação de insegurança e o clamor por punição evocado por grande parte da sociedade e estimulado pela mídia. Sob a denominação de luta contra a "pedofilia na internet" prevalecem no Brasil, medidas de ordem punitiva, como criação de novos tipos penais e aumento de penas. A dinâmica da violência sexual mediada pela TIC, porém, indica o papel essencial que as vítimas desempenham para o sucesso do aliciamento ou do abuso on-line; no entanto, as políticas nacionais de inclusão digital não têm sido acompanhadas pelos necessários investimentos em estratégias de prevenção vitimal. A presente pesquisa, portanto, sistematiza, de forma interdisciplinar, elementos que possam subsidiar estratégias de prevenção vitimal de violência sexual contra crianças e adolescentes mediada pela TIC. Parte de uma perspectiva dos direitos humanos de crianças e adolescentes (com foco nos direitos à participação e ao desenvolvimento) conectada a uma vitimologia que, integrada à criminologia, política criminal e dogmática jurídico-penal (Baratta, Anyiar de Castro), situa-se no paradigma das inter(relações) sociais (Pires) e considera crianças e adolescentes como sujeitos de direitos, mas também se preocupa com as percepções sociais a respeito do "crime" e do "criminoso", razão pela qual é também realizado um estudo das modalidades de violência sexual e de sua atual conformação na lei penal brasileira, com foco na violência sexual mediada pela TIC. A proposta integradora dos elementos estudados parte de um modelo de prevenção multissetorial baseado na ecologia social, com foco no empoderamento de crianças e adolescentes para, em nível de prevenção primária, estimular a adoção de atitudes de prevenção e de auto-cuidado, e, em nível comunitário e social, informar estratégias de prevenção integradas e medidas de prevenção secundária e terciária.

\section{PALAVRAS-CHAVE}

Criança e adolescente; violência sexual; tecnologia da informação e comunicação; prevenção vitimal; vitimologia; direito da criança e do adolescente. 


\section{ABSTRACT}

The Information and Communication Technology (ICT) is an elementary part of the unprecedented technological revolution that characterizes the "network society" (Castells) and that is accompanied by social, cultural and economic changes at various levels. At the same time it has undeniable benefits, such as communication without borders, the technological revolution also poses global challenges. Among these lies the multifaceted, global and interconnected sexual violence against children and adolescents. With the increasingly widespread use of ICT among Brazilian children and adolescents, the risks of the sexual abuse and grooming online (grouped here within the category of sexual violence mediated by ICT), affect all, but children and adolescents belonging to lower social classes are the most vulnerable. The real risks are increased by feelings of insecurity and the urge for punishment evoked by much of society and encouraged by the media. In the name of fighting against "pedophilia on the Internet", punitive measures are prevalent in Brazil, such as the creation of new crimes and increase of criminal penalties. Whyle the dynamics of the sexual violence mediated by ICT points to the essential role that victims play in the success of deception or abuse online, national policies of digital inclusion have not been accompanied by adequate investments in strategies of victimal prevention. This research, therefore, systematizes interdisciplinary elements that may support strategies of victimal prevention of sexual violence against children and adolescents mediated by ICT. The perspective adopted is the one of children's rights as human rights (focusing on the rights to participation and development) connected to a victimology (Baratta, Anyiar de Castro) that is integrated with criminology, criminal policy and criminal law, within the paradigm of social inter(relations) (Pires). The proposal, therefore, considers children and adolescents as subjects of rights, but also concerns the social perceptions about the "crime" and "criminal", reason why a study of the forms of sexual violence and its current conformation in the Brazilian criminal law is also carried out, focused in sexual violence mediated by ICT. A review of national and international victimological qualitative and quantitative surveys is included. These elements are integrated based on a multisectoral prevention model (social ecology), focusing on the empowerment of children and adolescents, at the level of primary prevention, to encourage the adoption of prevention attitudes and self-care, and, at community and social levels, to inform prevention strategies and integrated measures of secondary and tertiary prevention.

KEY-WORDS: Children; sexual violence; Information and Communication Technology; victimal prevention; victimology; child's rights. 


\section{RIASSUNTO}

La Tecnologia dell'Informazione e della Comunicazione (ICT) è una parte elementare della rivoluzione tecnologica senza precedenti che caratterizza la cosiddetta "società in rete" (Castells) ed è accompagnata dai cambiamenti sociali, culturali ed economici a vari livelli. Anche se ha dei vantaggi innegabili, come la comunicazione senza frontiere, la rivoluzione tecnologica pone anche sfide globali, come la violenza sessuale contro i bambini e gli adolescenti, multiforme, globale e interconnesso. Con l'uso della ICT sempre più diffuso tra i bambini e gli adolescenti brasiliani, i rischi di abuso sessuale e adescamento online, raggruppati qui sotto la categoria di violenza sessuale mediata dalle ICT, minacciano tutti, ma i bambini e gli adolescenti appartenenti a classi sociali più basse sono i più vulnerabili. Ai rischi reali vengono aggiunti sentimenti di insicurezza e il grido di punizione evocata dalla gran parte della società e incoraggiato dai media. Sotto il nome di "combattere la pedofilia su Internet" misure punitive sono prevalenti in Brasile, come la creazione di nuovi reati e sanzioni maggiori. Le dinamiche di violenza sessuale mediate dalle ICT, tuttavia, indicano il ruolo essenziale che le vittime giocano per il successo dell'abuso o adescamento online; tuttavia, le politiche nazionali di inclusione digitale non sono state accompagnate da adeguati investimenti negli strategie di prevenzione vittimale. Questa ricerca, dunque, sistematizza elementi interdisciplinari in grado di supportare le strategie di prevenzione delle vittime della violenza sessuale contro i bambini e gli adolescenti mediata dalle ICT. Parte della prospettiva dei diritti umani dei bambini e degli adolescenti (che si concentra sui diritti alla partecipazione e allo sviluppo) collegati ad una vittimologia integrata nella criminologia, politica criminale e dogmatica giuridico-penale (Baratta, Anyiar de Castro), si trova nel paradigma delle inter-(relazioni) sociali (Pires) e considera i bambini e gli adolescenti come soggetti di diritto. Si preoccupa, anche, con le percezioni sociali circa il "crimine" e il "criminale", il che giustifica uno studio sulle forme di violenza sessuale e la sua conformazione attuale nel diritto penale brasiliano. Presenta anche una revisione delle indagini quantitativa e qualitativa sulla vittimizzazione, nel livello nazionale ed internazionale. Gli elementi sono integrati da un modello di prevenzione multisettoriale basato sull'ecologia sociale, puntando sulla responsabilizzazione dei bambini e degli adolescenti a livello di prevenzione primaria, favorendo l'adozione di atteggiamenti di prevenzione e cura di sé, e informando le strategie di prevenzione nei livelli comunitari e sociali e misure integrate di prevenzione secondaria e terziaria.

PAROLE-CHIAVE: Bambini; violenza sessuale; Tecnologia dell'Informazione e della Comunicazione; prevenzione vittimale; vittimologia; diritto dei bambini. 


\section{Sumário}

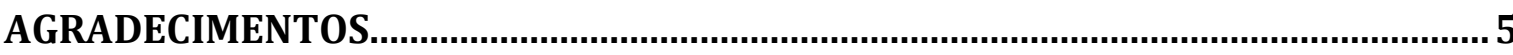

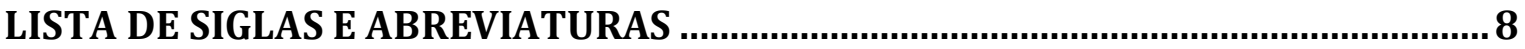

APRESENTAÇÃO

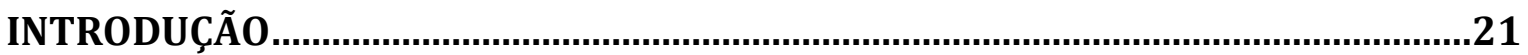

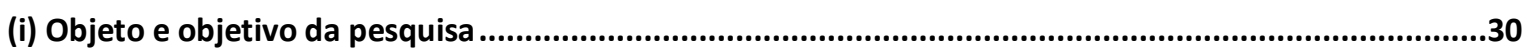

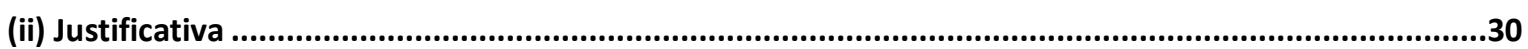

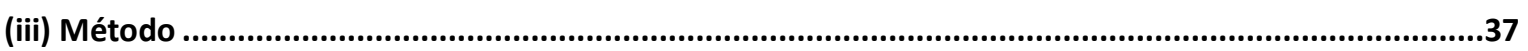

PARTE I. CRIANÇAS E ADOLESCENTES, A SOCIEDADE EM REDE E A TECNOLOGIA DE INFORMAÇÃO E COMUNICAÇÃO: RISCOS E BENEFÍCIOS....................................40

\section{CAPÍTULO 1. CRIANÇAS E ADOLESCENTES E A (CONTRADITÓRIA) SOCIEDADE

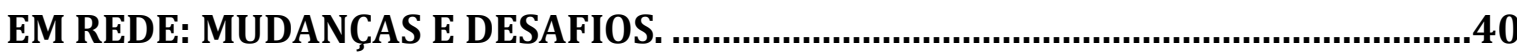

1.1. A sociedade em rede: comunicação, cultura e economia na era da informação. ................................42

1.1.1. Sociedade em rede: comunicação e sociabilidade. ..............................................................43

1.1.2. Sociedade em rede: mudanças estruturais em curso..........................................................51

1.1.3. Sociedade em rede: capitalismo informacional e violência contra crianças e adolescentes ...........53

1.2. Infâncias e Adolescências na sociedade em rede. ...........................................................................55

1.2.1. Infâncias e adolescências na sociedade em rede: cultura e valores na realidade brasileira............56

1.2.2. Infâncias e adolescências na sociedade em rede: cultura e práticas sociais on-line.......................63

1.2.3. Infâncias e adolescências na sociedade em rede: sexualidade e TIC ........................................67

1.3 Crianças, adolescentes e o uso da TIC no Brasil: contextualização quantitativa e qualitativa .............74

\section{CAPÍTULO 2 - VIOLÊNCIA SEXUAL CONTRA CRIANÇAS E ADOLESCENTES}

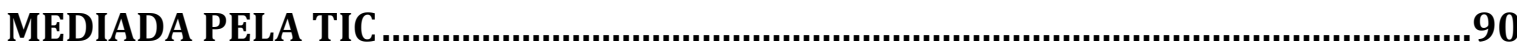

2.1. Violência sexual contra crianças e adolescentes: conceitos-chave................................................92

2.1.1. Violência, abuso e exploração sexual contra crianças e adolescentes .......................................93

2.1.2. Atores envolvidos na (com a) violência sexual contra crianças e adolescentes.....................129

2.2. Violência sexual contra crianças e adolescentes mediada pela TIC: abuso sexual on-line e aliciamento

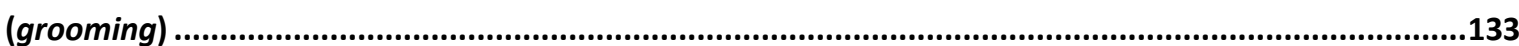

2.2.1. Pesquisas de vitimização e estatísticas oficiais .................................................................134

2.2.2. Abuso sexual on-Line, aliciamento (grooming) e violência sexual mediada pela TIC: definições ..138

2.2.3. Aliciamento (grooming) e abuso sexual on-line: dinâmicas.....................................................143

2.2.4. Aliciamento (grooming) e abuso sexual on-line: tipos penais. ................................................146 
2.2.5. Os danos efetivos e potenciais às crianças e adolescentes decorrentes da violência sexual mediada pela TIC

PARTE II - DIREITO DA CRIANÇA E DO ADOLESCENTE: PARTICIPAÇÃO E DESENVOLVIMENTO

\section{CAPÍTULO 3: INFÂNCIA, ADOLESCÊNCIA E PARTICIPAÇÃO: O DIREITO DE SER} CRIANÇA E DE SER ADOLESCENTE.

3.1. A participação de crianças e adolescentes na esfera jurídica internacional e nacional. .164

3.2. Participação de crianças e adolescentes e (é) protagonismo juvenil (?) .176

3.3. Participação de crianças e adolescentes nas políticas públicas .186

CAPÍTULO 4. INFÂNCIA, ADOLESCÊNCIA E DESENVOLVIMENTO: O DIREITO DE SER CRIANÇA E DE SER ADOLESCENTE.

4.1. O desenvolvimento de crianças e adolescentes na esfera jurídica internacional e nacional.

4.2. Crianças e adolescentes, sujeitos em desenvolvimento: caracterização biopsicossocial.

PARTE III - VITIMOLOGIA, CIÊNCIAS CRIMINAIS INTEGRADAS E PREVENÇÃO VITIMAL DA VIOLÊNCIA SEXUAL CONTRA CRIANÇAS E ADOLESCENTES MEDIADA PELA TIC.

\section{CAPÍTULO 5 -VITIMOLOGIA, CRIMINOLOGIA, POLÍTICA CRIMINAL E DIREITOS HUMANOS: PREVENÇÃO VITIMAL CENTRADA NA CRIANÇA E NO ADOLESCENTE}

5.2. Vitimologia, Criminologia, Política Criminal e Direitos Humanos: paradigmas para a prevenção vitimal.

5.4. Vitimização enquanto processo: coparticipação de crianças e adolescentes na dinâmica da violência sexual mediada pela TIC.

5.5. Prevenção Vitimal no âmbito da Vitimologia integrada aos Direitos Humanos e no paradigma das (inter)-relações sociais.

5.5.1. Multissetorialidade: Modelo da Ecologia Social dos Direitos da Criança e do Adolescente e Sistema

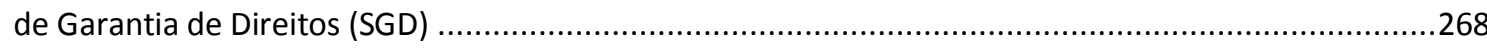

5.5.2. Fatores de risco (vulnerabilidade) e fatores de proteção ........................................................279 


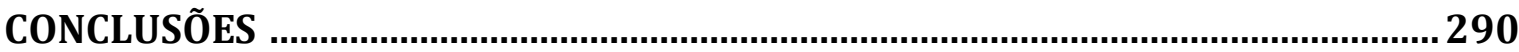

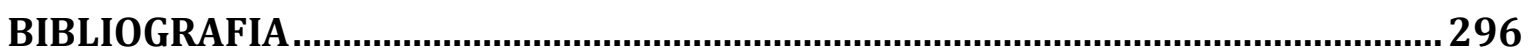

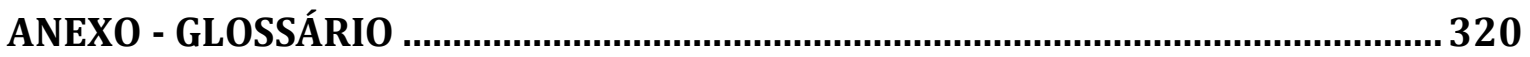




\section{APRESENTAÇÃO}

Considero sempre importante, antes de introduzir o leitor ao texto técnico, situar a pesquisa dentro da minha trajetória profissional (técnica/acadêmica). Ademais, creio que os temas que escolhemos dizem, no mais das vezes, um pouco sobre quem somos.

Este trabalho pontua o final de um ciclo que se iniciou em 2004. Minha trajetória na área da infância e juventude iniciou-se alguns anos após o término do bacharelado. Apesar de sempre ter me interessado pelas questões dessa área, somente após a graduação, quando buscava um tema adequado para o mestrado, uma feliz sincronicidade levou-me, em 2004, à PUC/SP e ao Núcleo de Estudos e Pesquisas sobre a Criança e o Adolescente do Programa de Pós-Graduação em Serviço Social (NCA), coordenado pelas Professoras Myrian Veras Baptista e Silvia Losacco. A formação recebida no NCA, não só acadêmica, mas também política, e os contatos profissionais ali iniciados foram, sem dúvida alguma, os desencadeadores do desenrolar de minha trajetória neste campo de pesquisa e de ação. Junto com esses pesquisadores, fundei uma associação em 2005, onde realizei meus primeiros trabalhos como "oficineira" e subcoordenadora de projetos, aprendi (na prática) como se estabelece e se gere uma ONG, e contei com preciosos interlocutores durante o mestrado, que defendi em 2008.

Foi a partir desses contatos que me tornei, inicialmente, assistente do Professor Paulo Afonso Garrido de Paula e, posteriormente, da Professora Martha de Toledo Machado, na disciplina de Direito da Criança e do Adolescente que ministram na graduação em Direito da PUC/SP. Esta oportunidade ímpar me proporcionou a formação dogmática na temática, que aliei à formação interdisciplinar que obtive no NCA e, ainda, nos créditos cursados durante o mestrado em outras unidades da USP, como o Instituto de Psicologia e a Faculdade de Filosofia, Letras e Ciências Humanas.

Durante o mestrado, no qual fui generosamente recebida pelo Professor Alvino Augusto de Sá, foram muitos e intensos os aprendizados: aprendi a aprender, a pensar, a questionar, a aceitar críticas, a lecionar, a trabalhar em grupo, e formei parcerias, inicialmente de trabalho, que viraram depois grandes e importantes amizades. As 
atividades desenvolvidas juntos aos grupos GDUCC e GETCrim ${ }^{1}$, e a oportunidade de aprender e partilhar das reflexões do Professor Alvino em diversas ocasiões foram fundamentais para a minha formação profissional e acadêmica; esta formação me possibilitou, mais adiante, por exemplo, assumir a desafiadora tarefa de elaborar um Manual de Tratamento Penitenciário em Direitos Humanos para o Sistema Penitenciário Federal/DEPEN/MJ (Departamento Penitenciário Nacional/Ministério da Justiça), em consultoria que foi financiada pelo PNUD (Programa das Nações Unidas para o Desenvolvimento), oportunidade de levar para a prática o pensamento crítico e as ideias de meu orientador e de seus inspiradores.

No início do doutorado, em 2009, os caminhos percorridos indicavam a continuidade da pesquisa na área anteriormente estudada: responsabilidade penal juvenil. As disciplinas cursadas para completar os créditos necessários não foram escolhidas por estarem diretamente ligadas à temática, mas me ajudariam a refletir a respeito. $\mathrm{Na}$ Faculdade de Direito da USP (Departamento de Direito Penal), cursei as disciplinas dogmáticas Temas Fundamentais de Direito Penal e Direito Penal e Religião oferecidas pelo Professor Miguel Reale Jr e pela Professora Dra. Janaína Paschoal. O ambiente de livre debate acadêmico proporcionado foi muito salutar; pude estudar e refletir a respeito de temáticas atuais e relevantes da dogmática jurídico-penal.

Já no Instituto de Psicologia, estudei e entusiasmei-me com a Psicologia do Desenvolvimento Moral, estudando Piaget, Kolhberg, Gilligan e outros, na disciplina conduzida pelo Prof. Yves de La Taille, que empolgou não só a mim, mas a todos os alunos, regulares e ouvintes. A escolha foi acertada, pois parte da presente pesquisa se

\footnotetext{
${ }^{1}$ O GDUCC (Grupo de Diálogo Universidade Comunidade e Cárcere) é um grupo de intervenção no cárcere idealizado, fundado e coordenado pelo Prof. Alvino Augusto de Sá (hoje co-coordenado também pelo Professor Sérgio Salomão Shecaira), do qual fui co-fundadora, junto com Ana Gabriela Mendes Braga, também aluna da pós-graduação; fomos também as primeiras coordenadoras adjuntas deste grupo e do GETCrim (Grupo de Estudos sobre Temas de Criminologia), ambos trabalhos voluntários desenvolvidos durante os três anos de mestrado e formalmente vinculados ao Departamento de Direito Penal, Medicina Forense e Criminologia da FDUSP. Atualmente, o GDUCC é uma atividade de extensão oficial da FDUSP, voltada a alunos de graduação, atua em três penitenciárias do Estado de São Paulo e tem o apoio da Secretaria de Administração Penitenciária do Estado de São Paulo e da Vara das Execuções Criminais da Comarca de Guarulhos, onde se localizam duas das Penitenciárias onde o grupo atua. Estou afastada das funções diretas de coordenação dos dois grupos desde 2009, mas ainda mantenho um forte vínculo com suas propostas e faço eventuais participações. Meu interesse maior, no momento, é no estabelecimento de um sistema de monitoramento e avaliação participativo das atividades do GDUCC.
} 
assenta sobre as bases da Psicologia do Desenvolvimento e sobre as próprias produções do Professor Yves de La Taille e de outros pesquisadores da disciplina.

Mais adiante, busquei descobrir afinal, o que era a "crítica" da "Criminologia crítica"; senti necessidade de conhecer as fontes em que beberam Alessandro Baratta e Eugênio Raul Zaffaroni. Assim, me deparei com a dura e, ao mesmo tempo, prazerosa, tarefa de estudar Adorno, Marcuse, Horkheimer, Honneth e outros grandes pensadores da antiga e atual escola de Frankfurt, guiada pelos Professores Pedro Fernando da Silva e Luís Galeão da Silva, em duas disciplinas de Teoria Crítica na Psicologia, sob duas óticas distintas, o que me proporcionou interessantes e desafiadores exercícios do pensar ${ }^{2}$.

$\mathrm{Na}$ fase de conclusão dos créditos, e já no momento de definir o tema e preparar o texto para a qualificação, iniciei o meu trabalho como Coordenadora do Programa CPP Parceria para a Proteção da Criança e Adolescente (Child Protection Partnership), contratada pelo IICRD - Instituto Internacional para os Direitos e Desenvolvimento da Criança e do Adolescente (International Institute for Child Rights and Development), uma organização não governamental baseada na Universidade de Victoria, British Columbia, Canadá.

“A Parceria para a Proteção da Criança e do Adolescente (CPP) é uma colaboração internacional e intersetorial de organizações para a proteção de crianças e adolescentes contra a exploração sexual infantojuvenil facilitada pela rápida e global expansão da tecnologia da informação e comunicação (TIC). Por meio de conhecimento, ferramentas e treinamentos, a CPP usa os benefícios da tecnologia para apoiar soluções que atendam as realidades das crianças e adolescentes no Brasil e nas outras localidades onde a CPP é implementada. O objetivo da CPP é reduzir e, onde possível, eliminar, a exploração sexual de crianças e adolescentes facilitada pela TIC, construindo a partir das boas práticas e da tecnologia, nos setores público e privado."3

\footnotetext{
${ }^{2}$ Embora o presente trabalho não incorpore diretamente conteúdos desses autores da Teoria Crítica, as leituras realizadas e as discussões em sala, nas duas disciplinas dedicadas ao tema, tiveram inegável valor nos caminhos de elaboração desta pesquisa.

${ }^{3}$ CURRIE, Vanessa. Relatório do Círculo dos Direitos - CPP Brasil: Exploração Sexual Infantojuvenil facilitada pela TIC: uma Análise a Partir das Realidades Vividas de Crianças e Adolescentes. Tradução: Viviane Fontoura; Coordenação e Revisão Técnica da edição brasileira: Maria Emilia Accioli Nobre Bretan. Victoria/BC: International Institute for Child Rights and Development, 2011 (no prelo; versão em inglês
} 
O diferencial da CPP, além do foco em uma parcela muito específica do tema complexo e delicado que é a violência sexual, é sua metodologia, denominada Círculo dos Direitos, que promove a real participação de crianças e adolescentes, empoderando-as ${ }^{4}$ e fazendo com que suas vozes e realidades vividas cheguem aos atores do Sistema de Garantia de Direitos (Família, Estado, Sociedade), em especial aos formuladores de políticas públicas nas três esferas de governo.

Apesar de um dos eixos de atuação da CPP ser o denominado "Law Enforcement", com parcerias estabelecidas com a Polícia Federal e Polícia Militar do Estado de São Paulo para apoiar uma série de projetos, o que mais me chamou a atenção na temática não foram as medidas de cunho repressivo e os investimentos em treinamento de pessoal e desenvolvimento de mecanismos de denúncia e investigação de redes internacionais produtoras de pornografia infantil e tráfico de crianças. Sobre estas questões, aliás, certamente muitos e bons pesquisadores debruçar-se-ão nos próximos anos. Foram os bons resultados ${ }^{5}$ atingidos no projeto, por meio de sua metodologia, que me proporcionaram a oportunidade de pensar a respeito da prevenção criminal com foco que até então nunca tinha chamado a minha atenção: o da vítima. Naturalmente, e desde o início, fez-se presente a ideia de um estudo com aportes teóricos da vitimologia, uma área relativamente nova para mim.

A assunção do cargo de Gestora do Programa CPP, que veio carregada de novas responsabilidades, a partir de Janeiro de 2011, mostrou que a opção pela pesquisa sobre o

disponível em http://childprotectionpartnership.org/resources/recommended/child-led-solutions/exploringict-enabled-child-sexual-exploitation-through-li); p.11-12.

4 Apesar de o verbo "empoderar" e o substantivo "empoderamento" não existirem na língua culta brasileira (são anglicismos, traduzidos dos termos "empowerment" e "to empower"), já há alguns anos têm sido amplamente utilizados em diversos setores sociais, em especial em práticas e documentos de ONGs nacionais e internacionais; optei por utilizá-los neste trabalho por considerá-los adequados para a temática em questão. A wikipedia define empoderamento como "dar às pessoas o poder, a liberdade e a informação que lhes permitem tomar decisões e participar ativamente da organização". Nota-se, portanto, que o significado do termo empoderamento vai além de "fortalecimento" ou "capacitação", pois empoderar implica em um conjunto de fatores, incluindo a promoção de (auto)confiança e de autonomia. O dicionário Aulete registra o termo "empoderar-se" com o significado de "apoderar-se; apossar-se", termos que não traduzem todos os conceitos embutidos no original "empowerment".

${ }^{5}$ Para resultados da CPP no Brasil, cf. CURRIE, Vanessa. Op cit. O Círculo dos Direitos é uma metodologia de pesquisa-ação, de modo que pouco se pode falar em resultados "quantitativos", exceto de forma indireta (esfera de influência). O que se verificou ao longo do processo, porém, foi a inegável capacidade de promover a participação de crianças e adolescentes na prevenção, além da promoção de diálogos importantes entre diversos setores do Sistema de Garantia de Direitos, de modo inclusivo. Estas iniciativas resultaram, por exemplo, no desenvolvimento de um jogo de prevenção on-line para crianças. A ideia foi dada pelas próprias crianças participantes do projeto durante uma reunião com adultos de diversas organizações parceiras, que buscavam identificar lacunas no desenvolvimento de currículo para a prevenção. 
tema foi acertada. Ainda mais imersa na temática, cotidianamente, seria muito difícil 'mudar a sintonia' para pensar sobre outras questões. Intensa energia psíquica e dedicação eram necessárias para desenvolver as duas difíceis tarefas: a pesquisa do doutorado (que exigia concentração, foco, crítica, tempo) e a gestão do programa (que envolvia responsabilidades diversificadas, com diferentes graus de complexidade).

Pesquisar o tema com que se trabalha proporciona reflexão sobre a própria prática, e, inegavelmente, a oportunidade de torná-la uma prática melhor. Este foi um dos maiores desafios, e as observações feitas pelos examinadores na banca de qualificação deixaram claro o quanto era importante o distanciamento para que esta reflexão fosse, de fato, crítica e pudesse contribuir para algo novo. Ao mesmo tempo, como o IICRD - instituto que executa o projeto - é ligado a uma universidade, constituído por pesquisadores e profissionais de campo (muitos desempenhando as duas funções), seus programas e projetos são sempre pensados a partir da perspectiva teórico-prática. Assim, algumas das reflexões centrais para este trabalho foram disparadas a partir destas perspectivas, que fundamentam a própria existência e atuação do IICRD, notadamente as ligadas ao Direito da Criança e do Adolescente. Busquei, assim, conjugar esses novos saberes com os saberes que já vinha estudando, há alguns anos, no âmbito das Ciências Criminais.

O presente trabalho representa, assim, a convergência de alguns dos temas pelos quais me interesso desde a graduação e de outros, que me chamaram a atenção posteriormente: as Ciências Criminais, os Direitos Humanos, e, dentro deles, o Direito da Criança e do Adolescente e a Psicologia. Por fim, apesar de não me considerar uma verdadeira geek $^{6}$, gosto de tecnologia e da internet, sendo a TIC um dos eixos centrais desta pesquisa.

$\mathrm{Na}$ base do meu interesse por todos esses temas está a crença no ser humano e em seu potencial para mudar e se reinventar. Neste trabalho, esta crença se traduz na perspectiva de oferecermos para crianças e adolescentes um ambiente saudável e seguro, em que possam se desenvolver exercitando seus direitos de forma plena e usufruindo do melhor que a tecnologia (em última instância, a ciência) possa oferecer para enriquecer

\footnotetext{
${ }^{6}$ Termo (gíria), em inglês, utilizado para fazer referência aos aficionados por tecnologia, que estão sempre a par das últimas novidades e utilizam os programas e equipamentos mais atualizados.
} 
suas vidas. Espero, com as reflexões ora apresentadas, ter sido capaz de contribuir para essa construção. 


\title{
INTRODUÇÃO
}

Em agosto de 2010, um popular site brasileiro publicou o seguinte artigo (do qual destaco um trecho) em sua página sobre tecnologia:

\begin{abstract}
"Logo depois do lançamento do iPad, enquanto adultos comentavam extasiados o fato de a Apple ter criado um tablet com tela sensível ao toque, uma garotinha de dois anos e meio fez sucesso no Youtube pela naturalidade com que interagia com o novo gadget (o objeto de desejo/2010 entre os fãs de tecnologia). A menina do vídeo e aquele seu sobrinho de seis anos que já usa o Messenger são exemplos de como a tecnologia conquista seus usuários cada vez mais cedo - apesar de, muitas vezes, as crianças não estarem preparadas para os riscos que ela traz. Ou seja: os pequenos podem aprender a usar computadores e gadgets sozinhos, mas eles ainda precisam de (muita) orientação sobre como utilizar essas ferramentas da forma correta."
\end{abstract}

Se em 2010, quando foi publicada a reportagem, a cena acima descrita causava espanto, crianças como a garotinha de dois anos de idade que interage com um equipamento por meio de uma tela sensível ao toque, hoje, já não podem mais ser consideradas exceção ${ }^{8}$.

Chamados de nativos digitais ${ }^{9}$, à primeira vista, essas parecem ser as crianças e os adolescentes nos quais se foca a presente pesquisa. De fato, como indica a própria reportagem, os pais e educadores dessas crianças e adolescentes têm demonstrado preocupação com a segurança de seus filhos ao utilizar a tecnologia, especialmente quando se trata de protegê-los da ameaça dos "pedófilos". A mídia também comparece, engrossando o coro contra a "pedofilia"10, pedindo punições mais severas e divulgando com interesse e estardalhaço o desbaratamento de organizações internacionais de produção

\footnotetext{
${ }^{7}$ IKEDA, Ana. Autodidatas da tecnologia, crianças ignoram bê-á-bá da segurança online. UOL Tecnologia. 02/08/2010. Disponível em http://tecnologia.uol.com.br/seguranca/ultimas-noticias/2010/08/02/autodidatasda-tecnologia-criancas-ignoram-be-a-ba-da-seguranca-online.jhtm, consulta em 04/10/2011.

${ }^{8}$ Aliás, até mesmo animais (por exemplo, um gato) já foram filmados interagindo com tablets, estimulados por programas especialmente criados para atrair sua atenção.

${ }^{9}$ Crianças e adolescentes que têm acesso à tecnologia desde bebês. Para explicação mais detalhada do termo, confira o Capítulo 1.

${ }^{10}$ O uso dos termos "pedófilo" e "pedofilia" entre aspas é proposital. Uma breve discussão a respeito desses e de outros termos, e de sua utilização estigmatizante será feita no Capítulo 2.
} 
e distribuição de pornografia infantil, contribuindo para a criação de um clima de tensão social a respeito da questão.

Não se pode dizer que o medo de ter seu filho aliciado por meio de chats, redes sociais e outras Tecnologias da Informação e Comunicação (TIC) não seja justificável e não corresponda a uma realidade. $\mathrm{O}$ aliciamento de crianças e adolescentes on-line e o abuso sexual on-line são reais. Ao mesmo tempo, também é certo que o temor transmitido pela mídia cria uma sensação de insegurança que, em geral, não corresponde ao tamanho do risco ${ }^{11}$.

O que as pesquisas indicam, porém, é que, por uma série de razões, o risco de aliciamento e abuso sexual on-line parece ${ }^{12}$ ser menor justamente para os nativos digitais; ironicamente, são estas as crianças e adolescentes representados na reportagem referida e em muitas outras.

De fato, como se verá ao longo deste trabalho, o uso da tecnologia já está disseminado dentre as crianças e adolescentes brasileiras. E uma parcela considerável - e cada vez maior - dessas crianças e adolescentes é de classes sociais baixas. Essas crianças usam a tecnologia com pouca informação a respeito dos riscos que apresenta e a respeito de como preveni-los, como reagir diante de uma situação que lhes cause desconforto ou medo, ou a quem pedir ajuda. Esses fatores, entre outros, aumentam sua vulnerabilidade.

Independente da classe social, todos estes meninos e meninas ${ }^{13}$ nasceram em uma sociedade globalizada e informatizada, chamada pelo sociólogo Manuel CASTELLS de sociedade em rede ${ }^{14}$. A sociedade em rede se desenvolve junto com o rápido desenvolvimento da TIC, e a internet é a tecnologia que representa esta sociedade de maneira mais emblemática. A internet, rede de redes, derruba fronteiras e permite, entre

\footnotetext{
${ }^{11}$ Para uma breve contextualização a respeito da questão do medo do crime e do risco, cf Capítulo 5.

12 Ainda não há estatísticas a respeito; as pesquisas consultadas, referidas ao longo deste trabalho, demonstram que pais de nativos digitais também são usuários de tecnologia e, portanto, sabem orientar melhor os seus filhos quanto ao uso seguro.

${ }^{13}$ Os termos "menino(s)" e "menina(s)" são usados, ao longo deste trabalho, para identificar crianças e adolescentes, respectivamente, dos sexos masculino e feminino. Não houve preocupação em tematizar questões de gênero e de orientação sexual na presente tese, já que essas temáticas ampliariam os limites do objeto. Quanto à definição de criança e adolescente, adota-se aqui a contida no artigo $2^{\circ}$ do ECA: "Considera-se criança, para os efeitos desta Lei, a pessoa até doze anos de idade incompletos, e adolescente aquela entre doze e dezoito anos de idade".

${ }^{14}$ CASTELLS, Manuel. A Era da Informação: economia, sociedade e cultura, vol. 1 (A Sociedade em rede). $14^{\mathrm{a}}$ reimpressão. São Paulo: Paz e Terra, 1999.
} 
outras coisas, conexões nunca antes imagináveis e comunicações em tempo real em qualquer ponto do mundo com pessoas conhecidas ou desconhecidas.

Ao mesmo tempo em que, imersas nesse mundo, aprendem a utilizar computadores, celulares e outros aparelhos de informação e comunicação cada vez mais cedo, usufruindo dos benefícios da TIC, crianças e adolescentes da chamada geração digital expõem-se aos riscos desse uso precoce contínuo, que incluem desde problemas oftalmológicos devidos à falta de estímulo ao nervo óptico para enxergar de longe (miopia induzida pelo excesso do uso do computador) até problemas de depressão e isolamento social.

Porém, enquanto os mencionados riscos do uso contínuo tendem a atingir primordialmente a parcela mais conectada desses jovens usuários, são as crianças mais pobres e menos conectadas que estão mais expostas aos riscos que aqui definimos como violência sexual mediada pela TIC, que inclui o aliciamento para fins de abuso, exploração sexual e tráfico internacional de seres humanos e o abuso sexual on-line. ${ }^{15}$

Por sua condição peculiar de pessoa em desenvolvimento, que, em geral, os torna mais vulneráveis que os adultos, crianças e adolescentes podem não ser capazes de identificar esses riscos ao utilizar a tecnologia ou, identificando-os, podem subestimar a sua intensidade ou superestimar a própria capacidade de evitar possíveis consequências de comportamentos de risco.

No caso especial dos adolescentes, devem ser consideradas, ainda, as naturais experimentações que fazem parte do desenvolvimento saudável da sexualidade, que ganha força a partir da puberdade ${ }^{16}$.

Além dessas peculiaridades, crianças e adolescentes de classes sociais mais baixas vivenciam outros elementos complicadores, que os tornam ainda mais vulneráveis, como a falta de orientação dos pais e educadores e a falta de informação e acesso sobre a quem recorrer caso algo aconteça.

\footnotetext{
${ }^{15}$ Para o conceito de violência sexual mediada pela TIC adotado neste trabalho, cf Capítulo 2.

${ }^{16} \mathrm{Cf}$, a respeito, Capítulo 4.
} 
Ao risco real soma-se a sensação de insegurança e o clamor por punição evocado por grande parte da sociedade e estimulado pela mídia. Alguns setores do Estado (com destaque para o poder legislativo) e movimentos da sociedade civil captam esses temores e fazem da "luta contra a pedofilia na internet" a sua bandeira ${ }^{17}$.

De fato, a proteção de crianças e adolescentes contra a exploração sexual é unânime entre movimentos sociais: não há quem não se choque e sensibilize diante da violação de uma criança ou de um bebê ou de cenas de crianças circulando entre clientes de hotéis ou bares "especializados em turismo sexual".

O que se verifica, porém, no Brasil, em termos de políticas públicas (inclusive política criminal) para o enfrentamento da delicada questão da violência sexual mediada pela TIC é a prevalência de um movimento que Maria Lúcia KARAM denominou de esquerda punitiva ${ }^{18}$, que predomina entre as entidades de defesa de direitos da criança, combinado com um fortíssimo movimento de Lei e Ordem, em constante expansão, que tem como representantes de peso Deputados e Senadores que não hesitam em defender, ao mesmo tempo, duas bandeiras (que, apenas aparentemente, são) completamente contraditórias: a proteção de crianças e adolescentes contra a "pedofilia na internet" e a redução da maioridade penal.

Se o governo brasileiro tem investido, nos últimos anos, em políticas nacionais de inclusão digital ${ }^{19}$, elas não têm sido acompanhadas pelos necessários investimentos em

${ }^{17}$ Cf., a respeito, Capítulo 5.

${ }^{18}$ KARAM, Maria Lúcia. A esquerda punitiva. Discursos Sediciosos: crime, direito e sociedade, Rio de Janeiro, v. 1, n. 1, p.79-92, 1996.

${ }^{19}$ Faço referência, por exemplo, ao programa UCA (Um Computador por Aluno), que "tem como objetivo ser um projeto Educacional utilizando tecnologia, inclusão digital e adensamento da cadeia produtiva comercial no Brasil". Segundo o site oficial do Programa, "em Janeiro de 2010 o consórcio CCE/DIGIBRAS/METASYS foi dado como vencedor do pregão $\mathrm{n}^{\circ}$ 107/2008 para o fornecimento de 150.000 laptops educacionais a aproximadamente 300 escolas públicas já selecionadas nos estados e municípios. Cada escola receberá os laptops para alunos e professores, infraestrutura para acesso à internet, capacitação de gestores e professores no uso da tecnologia. Seis municípios serão atendidos como UCA Total, onde todas as escolas serão atendidas pelo projeto." (fonte: http://www.uca.gov.br/institucional/projeto.jsp, consulta em 15.03.2012). Ainda a título de exemplo, foi lançado em 2008 o Programa Banda Larga nas Escolas (PBLE), que tem como objetivo "conectar todas as escolas públicas urbanas à internet, rede mundial de computadores, por meio de tecnologias que propiciem qualidade, velocidade e serviços para incrementar o ensino público no País", sendo que (...) "as operadoras autorizadas trocam a obrigação de instalarem postos de serviços telefônicos (PST) nos municípios pela instalação de infraestrutura de rede para suporte a conexão à internet em alta velocidade em todos os municípios brasileiros e conexão de todas as escolas públicas urbanas com manutenção dos serviços sem ônus até o ano de 2025". (Fonte: Portal do MEC, Secretaria de Educação à Distância, disponível em 
políticas/programas/projetos/ações de prevenção, com o intuito de educar crianças e adolescentes para práticas seguras de uso da tecnologia.

As ações até agora tomadas em nível de política têm sido tão somente a realização de investigações, como a CPI da Pedofilia do Senado e a edição, apressada e sem o amplo e necessário debate público, de legislação penal repressora. Não há critérios mínimos claramente estabelecidos para o desenvolvimento de estratégias de prevenção de violência sexual mediada pela TIC e os programas/projetos/ações desenvolvidos desde o Plano Nacional de 2002 até o momento constituem-se em ações isoladas, desencadeadas principalmente por organizações não governamentais, que não têm uniformidade quanto a premissas e objetivos, em muitos casos contribuindo para o reforço de uma ideologia do medo do crime, ao invés de promover o uso seguro da tecnologia e incentivar a criação de redes de solidariedade aproveitando as próprias tecnologias e as redes sociais.

Apesar desse movimento, as características do que aqui se está chamando de violência sexual contra crianças e adolescentes mediada pela TIC, deixam clara a necessidade de uma política de prevenção primordialmente focada na vítima (melhor dizendo, nas vítimas potenciais), também denominada prevenção vitimal.

A dinâmica das condutas de violência sexual mediada pela TIC indica o papel essencial que as vítimas desempenham para que o autor tenha sucesso em seu objetivo de aliciar ou abusar sexualmente da criança ou adolescente do outro lado da tela.

É necessário, portanto, desviar o tradicional foco de estudos de prevenção - do "criminoso", "delinquente", "pedófilo" - para a criança ou o adolescente que se encontra em situação de vulnerabilidade.

A partir de uma perspectiva de prevenção vitimal, estratégias (políticas/programas/projetos/ações) de enfrentamento da violência sexual mediada pela TIC devem se basear em princípios e diretrizes interdisciplinares, notadamente dos direitos humanos de crianças e adolescentes e da vitimologia de caráter humanista e integrada às demais ciências criminais, com o objetivo de promover a participação ativa e solidária de crianças e adolescentes na identificação de riscos e na busca de soluções. Esses critérios 
devem considerar a realidade em que estão inseridas crianças, adolescentes, suas famílias, escola e sociedade hoje, os usos que crianças fazem da tecnologia, os riscos e benefícios que apresentam.

As características da sociedade em que hoje vivemos, marcada pela expansão rápida da tecnologia, que vem acompanhada de novas formas de sociabilidade, pelo declínio do patriarcalismo e novos modos de organização familiar, economia global, capitalismo informacional, tampouco podem ser excluídas da equação.

A abordagem interdisciplinar se faz necessária pela própria característica da temática, que requer apreciações que partam do mundo da criança, do adolescente e de seus direitos, abrangendo, ainda, os atores do Sistema de Garantia de Direitos da Criança e do Adolescente (SGD) responsáveis pelo cuidado desses sujeitos em desenvolvimento (a escola, a família e a comunidade), e que considerem, também, os efeitos que estratégias de prevenção exercem sobre as percepções sociais a respeito do "crime" e do "criminoso".

Cabem, ainda, alguns esclarecimentos para melhor delimitar os contornos da pesquisa.

Não se encontrará, aqui, uma apresentação de "histórico" sobre a temática central ou sobre seus subtemas, como é tradicional nas teses e dissertações produzidas na área do Direito. A uma, porque se trata, em parte, de tema atualíssimo (a história da internet e demais tecnologias hoje abrigadas na expressão "tecnologia da informação e comunicação" - TIC - não tem mais que 50 anos; o mesmo não se pode dizer da violência sexual contra crianças e adolescentes, que sempre existiu, embora antes não tivesse nome e nem merecesse tanto destaque); a duas, porque muitos outros pesquisadores já apresentaram a história da violência sexual contra crianças ou a história do nascimento da internet e da era da informação de modo aprofundado, razão pela qual são referenciados neste trabalho. Assim, eventual digressão histórica é feita quando necessária para a contextualização ou discussão do tema em questão.

É preciso, ainda, salientar que o foco desta pesquisa não é a política criminal de prevenção de delitos relacionada ao autor de crime, entendida tanto como política de conscientização da população, intervenção precoce junto a grupos considerados de risco ou intervenções a posteriori (identificadas com as teorias da pena e, em última instância, 
com a própria função do Direito Penal). Por esta razão, não se faz um exame aprofundado dos delitos, de seus autores identificados ou potenciais, das motivações ou causas do delito, da política de penas etc, seja sob a perspectiva dogmática, seja sob a perspectiva criminológica ou político-criminal.

Apesar de realizado no âmbito de um programa de pós-graduação em Direito, este trabalho também não se propõe a examinar os crimes do ponto de vista vitimodogmático. Assim, não são discutidas a fundo categorias como bem-jurídico penal, e tampouco são examinadas a fundo as opções valorativas consubstanciadas na lei. Também não é objetivo deste trabalho apresentar propostas de construção ou interpretação legislativa, características da dogmática.

Não se ignora que as Ciências Criminais constituem um todo que, apesar de composto de partes distintas e com escopos e metodologias bastante específicos, deve ser pensado, formulado e executado de modo integrado. Porém, abordar em profundidade todos estes aspectos requereria uma dedicação e aquisição de saberes que não são realizáveis no âmbito de um trabalho individual e limitado no tempo, como é o caso da presente tese. Mais ainda porque outro ramo do saber jurídico, que é o Direito da Criança e do Adolescente, vem acrescentado às bases teóricas utilizadas neste trabalho.

Assim, aspectos que se relacionam com o tema do trabalho, mas que não são diretamente pertinentes a ele, como discussões a respeito da criminalização ou não de determinadas condutas, ou mesmo debates aprofundados a respeito da consequência da participação da vítima na formulação das figuras típicas ou na sua aplicação aos casos concretos, não são realizados neste trabalho, por não constituírem seu objeto principal.

Espera-se que as questões suscitadas possam despertar outras reflexões, mais aprofundadas, sobre cada uma dessas temáticas específicas; além disso, almeja-se que os elementos desenvolvidos sejam, também, úteis aos profissionais do Sistema de Garantias de Direitos da Criança e do Adolescente (SGD), em todos os níveis, que enfrentam, cotidianamente, as angústias sobre como encaminhar as questões delicadas que dizem respeito à proteção de crianças e adolescentes, subsidiando a criação de estratégias para o enfrentamento da violência sexual mediada pela TIC. 
Para os fins deste trabalho, por Tecnologia da Comunicação e Informação (TIC) entende-se a "expressão geral que inclui qualquer aparelho de comunicação ou sua utilização, abrangendo rádio, televisão, telefones celulares, computadores, equipamentos (hardware) e programas (software) de rede e sistemas de satélite, bem como os diversos serviços e aplicações nos quais são utilizados, como videoconferências, bate-papo on-line, educação à distância etc" ${ }^{\text {20 }}$.

O enfoque vitimológico, apesar de apresentado ao final, perpassa todo o trabalho; buscou-se construir a pesquisa, preferencialmente, a partir de outras pesquisas que tenham foco na criança/adolescente e/ou que tenham buscado ouvir as vozes de crianças e adolescentes a respeito de suas próprias realidades.

A pesquisa é apresentada em três partes. Na Parte I, organizada em dois capítulos, apresenta-se um quadro breve da sociedade pós-moderna, caracterizada a partir dos estudos do sociólogo Manuel CASTELLS, com foco, especialmente, nas transformações geradas pela revolução da TIC, nas novas formas de sociabilidade atreladas ao uso da TIC e na relação entre violência contra crianças e adolescentes e as transformações econômicas na sociedade em rede. Apresentam-se os desafios e oportunidades que as novas TIC trazem para a vida de crianças, e a interação de suas condições de vida off-line com a sua vivência on-line. Valores, usos e costumes de crianças e adolescentes, semelhanças e diferenças entre classes e realidades sociais diferentes são enfocados, dentro das limitações a que se restringe este trabalho. É feita, ainda, uma revisão de pesquisas com dados qualitativos e quantitativos a respeito dos usos da TIC por crianças e adolescentes no Brasil.

Ainda na Parte I, Capítulo 2, são sistematizados, de forma interdisciplinar, conceitos-chave para a compreensão das múltiplas e integradas facetas do que se entender por violência sexual contra crianças e adolescentes e, mais especificamente, do que se entende aqui por violência sexual mediada pela TIC, delimitando-se mais o foco do

\footnotetext{
${ }^{20}$ A definição ora utilizada pretende ser de rápida compreensão; não se ignora, porém, que a expressão TIC se relaciona a um novo paradigma tecnológico e, portanto, contém em si mais que meras exemplificações de tipos de tecnologias. Para uma elaboração um pouco mais detalhada a respeito, cf Capítulo 1.

CURRIE, Vanessa. Série de Manuais do Círculo dos Direitos da CPP: Planejamento Reflexivo para Mudança Social. Tradução: Viviane Fontoura; Coordenação e Revisão Técnica da edição brasileira: Maria Emilia Accioli Nobre Bretan. Victoria/BC: International Institute for Child Rights and Development, 2011. (no prelo); p.154.
} 
trabalho. Os conceitos de violência, abuso e exploração sexual e as definições de autores de violência sexual são estudados a partir da perspectiva jurídica (nacional e internacional, com apoio, especialmente nos estudos de MACHADO), à qual são incorporados aportes de outros saberes (ciências sociais e psicologia) para a sua compreensão. A violência sexual mediada pela TIC é caracterizada não somente a partir do enfoque jurídico-penal (e de seu tratamento no direito brasileiro), mas também inclui dados de pesquisas de vitimização feitas com crianças e adolescentes, e uma descrição da dinâmica do aliciamento e abuso sexual on-line entre o adulto e a criança/adolescente.

Na Parte II, o foco passa para os direitos de crianças e adolescentes, dentro da perspectiva dos Direitos Humanos. O Capítulo 3 concentra-se no estudo do direito à participação, ainda negligenciado no Brasil tanto no campo teórico quanto na prática. Parte-se dos documentos internacionais de direitos e, posteriormente, investiga-se a interpretação que a ele tem sido dada na doutrina jurídica nacional. Além disso, examinam-se a concepção como protagonismo juvenil (COSTA) e identificam-se práticas exitosas de participação de crianças e adolescentes no Brasil.

Um estudo interdisciplinar do direito ao desenvolvimento é realizado no Capítulo 4, a partir de documentos nacionais e internacionais, tanto do ponto de vista jurídico quanto a partir dos aportes teóricos da psicanálise (FREUD e WINNICOTT, especialmente) e da psicologia do desenvolvimento (PIAGET, LA TAILLE). A estreita conexão entre o desenvolvimento e a participação é apresentada, sendo que os estudos são diferenciados em criança e adolescentes.

Na Parte III, é realizado um estudo a respeito da perspectiva vitimológica que, integrada com os Direitos Humanos, com a Criminologia, a Política Criminal e a Dogmática, adote uma visão de crianças e adolescentes como sujeitos de direitos e rompa com os estereótipos comumente atribuídos não só a estes sujeitos, mas também ao "pedófilo" (aqui chamado de ator envolvido na (com a) violência sexual contra crianças e adolescentes). Identifico a visão a respeito de crianças e adolescentes ligada às doutrinas tutelares de menores, ainda hoje presente no discurso jurídico-penal e, até recentemente, também na literatura vitimológica e no meio social, que se reflete nas medidas políticocriminais prevalentemente repressoras que têm sido adotadas para o enfrentamento da violência sexual mediada pela TIC. Promovo um diálogo entre a Criminologia e 
Vitimologia críticas de BARATTA e ANYIAR DE CASTRO e o paradigma das (inter-) relações sociais proposto por PIRES, a partir da interpretação de SÁ, advogando por uma perspectiva vitimológica integradora.

Apresenta-se a seguir um modelo de intervenção que se considera adequado para a elaboração de estratégias de prevenção vitimal, ligado à psicologia do desenvolvimento, identificando suas principais características e a sua pertinência com a questão da prevenção da violência sexual mediada pela TIC. Identifica-se também uma lacuna, propondo-se a inserção consciente de uma reflexão a respeito do medo do crime, no sentido de aproximar a proposta interventiva do paradigma vitimo-criminológico identificado anteriormente; ao final, apresentam-se sucintamente os três níveis de prevenção vitimal (primária, secundária e terciária).

$\mathrm{Na}$ Conclusão, busca-se a integração entre as três partes do trabalho, sistematizando-os de modo a indicar os elementos que, na presente proposta, devem ser contemplados na elaboração de estratégias de prevenção vitimal de violência sexual contra crianças e adolescentes mediada pela TIC.

\section{(i) Objeto e objetivo da pesquisa}

Objeto: prevenção vitimal da violência sexual contra crianças e adolescentes mediada pela Tecnologia de Informação e Comunicação (TIC).

Objetivo: identificar elementos teórico-práticos interdisciplinares que possam subsidiar estratégias (políticas/programas/projetos/medidas) de prevenção vitimal da violência sexual contra crianças e adolescentes mediada pela Tecnologia de Informação e Comunicação

\section{(ii) Justificativa}

Em novembro de 2008, entre os dias 25 e 28, realizou-se no Rio de Janeiro o III Congresso Mundial de Enfrentamento da Exploração Sexual de Crianças e Adolescentes, com a participação maciça de governos, organizações intergovernamentais, organizações 
não-governamentais, instituições de direitos humanos, ouvidores, setor privado, operadores do direito, líderes religiosos, parlamentares, pesquisadores e acadêmicos, sociedade civil e crianças e adolescentes.

Como parte do Tema 1 - Formas de Exploração Sexual Comercial e Seus Novos Cenários foram realizadas as seguintes oficinas específicas no eixo pornografia infanto juvenil na internet ${ }^{21}$, com a participação de crianças e adolescentes ${ }^{22}$ :

- $\quad$ Interação no âmbito virtual e seu impacto na proteção de crianças e adolescentes;

- $\quad$ Vulnerabilidade, resiliência e respostas terapêuticas em relação à vitimização no âmbito virtual;

- Análise e coleta de dados relativos ao abuso sexual dentro e fora da internet;

- $\quad$ Identificação das vítimas e apoio;

- $\quad$ Prevenção e educação para a auto-proteção da criança e do adolescente [destaquei]

Dentre outras recomendações realizadas por este grupo de trabalho ${ }^{23}$, a autoproteção de crianças e adolescentes aparece em destaque, merecendo a seguinte recomendação (in verbis):

"É fundamental a implementação de programas de sensibilização para educar as crianças e pais sobre os riscos potenciais associados ao uso de novas tecnologias. O estímulo

${ }^{21}$ Cada painel teve suas discussões pautadas em eixos estratégicos. Para o tema 1 - Formas de Exploração Sexual Comercial e Seus Novos Cenários, os eixos apontados foram:

- tráfico interno e internacional;

- pornografia infanto-juvenil na internet;

- exploração sexual de crianças e adolescentes no turismo;

- exploração sexual de crianças e adolescentes em situação de prostituição. (Anais do III Congresso Mundial de Enfrentamento da Exploração Sexual de Crianças e Adolescentes do III Congresso Mundial de Enfrentamento da Exploração Sexual de Crianças e Adolescentes Rio de Janeiro, 2008. Disponível em http://portal.mj.gov.br/sedh/Anais-IIICM.pdf, download em 20/12/2012; p. 16.)

22 Anais do III Congresso... p. 17.

${ }^{23}$ Constam, ainda, deste Grupo de Trabalho, recomendações a respeito da necessidade de avanços legislativos (complicado por conta do desenvolvimento contínuo da tecnologia); aprimoramento da cooperação entre países; ferramentas eficazes para a coleta e análise de informações de abuso sexual online, criação de unidades nacionais especializadas para investigação, assim como para o atendimento de vítimas e serviços de assistência aos infratores; treinamento de agentes da Lei; necessidade de maior informação ao público em sites e redes sociais a respeito dos riscos ou criação de sistema de bloqueio de informações; necessidade de melhoria dos filtros de material pornográfico na Internet e de prioridade no desenvolvimento e implementação de safelines e hotlines e procedimentos de denúncias seguras e simples; proibição de criação, distribuição e visualização de imagens e materiais relacionados a abusos contra crianças em todos os países; treinamento e advocacy. O escopo da maior parte dessas recomendações, todavia, foge do objeto desta pesquisa, razão pela qual não serão objeto de análise. Anais do III Congresso Mundial... p. 50-51. 
à utilização segura das novas tecnologias e comportamentos de auto-proteção deve ser introduzido em todos os currículos nas escolas, juntamente com uma formação adequada dos professores" ${ }^{24}$.

A participação de crianças e adolescentes também mereceu destaque durante o Congresso, tendo sido, aliás, um de seus diferenciais. Dentre as recomendações do grupo que trabalhou sobre esta temática se encontram a necessidade de "promoção da participação significativa e ética das crianças" e da importância da promoção "da institucionalização da sua participação a partir de uma abordagem baseada em direitos"; a necessidade de estabelecimento, pelos governos, de "estratégias claras sobre a forma como pretendem promover o direito das crianças à participação, incluindo o fornecimento de informações e de estruturas protetivas para crianças, o envolvimento de crianças no processo de decisão (como na formulação de políticas, mas também no desenvolvimento de programas de reabilitação para sobreviventes de exploração sexual)"; com o "uso de ferramentas específicas que permitam e promovam a participação autônoma das crianças e adolescentes na construção de políticas públicas"25.

A Declaração do Rio de Janeiro para Prevenir e Eliminar a Exploração Sexual de Crianças e Adolescentes ${ }^{26}$, documento resultante do Congresso, deixa clara, no Preâmbulo, a preocupação com a temática: "Expressamos preocupação com a continuidade dos elevados níveis de exploração sexual de crianças e adolescentes em Estados de todas as regiões, com o aumento de determinadas formas de exploração sexual de crianças e adolescentes, em particular por meio do abuso da Internet e de tecnologias novas e em desenvolvimento, e como resultado da crescente mobilidade de violadores em viagens e no turismo". [destaquei]

Outra preocupação apresentada no Preâmbulo da Declaração é com a falta de informação baseada em conhecimentos atualizados e na "riqueza das experiências de campo nas áreas da prevenção e proteção de crianças, cumprimento da lei e apoio a

\footnotetext{
${ }^{24}$ Anais do III Congresso... p. 53.

${ }^{25}$ Idem, p.54 55.

${ }^{26}$ Idem, anexo III, p. 65.
} 
vitima", assim como com a "insuficiência de trocas proativas de experiências e de lições aprendidas" (item 22).

A Declaração recomenda ainda a realização de pesquisas a respeito de “(...) novas manifestações de exploração sexual, incluindo mudanças de modalidades, atores, mecanismos e locais utilizados; (...) a natureza e o impacto da interação social virtual entre crianças e seu potencial para prevenir a exploração sexual de crianças $e$ adolescentes e a proteção destes em contextos culturais e sociais diversos (...)”. [destaquei]

Desde a elaboração do Plano Nacional de Enfrentamento da Violência Sexual Infanto-Juvenil, em 2002, o foco da política nacional de enfrentamento tem sido o atendimento de crianças e adolescentes vítimas de abuso e exploração sexual. Diversas medidas têm sido tomadas neste sentido, dentre outras, medidas de atendimento, como a oitiva humanizada de crianças e adolescentes vítimas de violência sexual (chamada de "depoimento especial" ou "depoimento sem dano") e a implementação do Disque Denúncia (Disque 100) e de recepção de denúncias on-line pela Polícia Federal (http://denuncia.pf.gov.br/).

Programas preventivos também têm sido desenvolvidos, como a divulgação de informações de proteção por meio de cartilhas, gibis e outros meios, publicados on-line e em papel, para diversos públicos-alvo. Cursos, capacitações e oficinas têm sido desenvolvidos por Organizações Não Governamentais (ONGs) nacionais e internacionais como Safernet, Childhood Brasil e IICRD.

No processo de revisão do Plano Nacional de Enfrentamento da Violência Sexual Infanto-Juvenil deixou-se claro que há uma carência de um debate aprofundado para definir conceitos e métodos que orientem o trabalho de prevenção à violência sexual, com ênfase no "empoderamento de crianças e adolescentes, para que possam conhecer, defender e exercer de forma segura e protegida a sua sexualidade", sendo um desafio "vencer a visão adultocêntrica"27.

${ }^{27}$ O processo de revisão do Plano Nacional: Relatório de Acompanhamento 2007-2008. Brasília, 2008; p. 11. 
A revisão do Plano incorporou, ainda, a previsão de outras medidas para o enfrentamento da violência sexual contra crianças e adolescentes facilitada pela Tecnologia da Informação e Comunicação (TIC). Há, portanto, ao menos por parte dos atores do Sistema de Garantia de Direitos (SGD), uma intenção de estabelecer uma política coerente para o enfrentamento da questão.

Por outro lado, o punitivismo ainda tem seu espaço garantido, o que pode ser observado por um rápido exame do relatório final da CPI da Pedofilia ${ }^{28}$ : a maior parte das recomendações consiste em medidas punitivas ou de investigação e persecução penal que vão de incremento de penas e condições mais duras de cumprimento de penas para "pedófilos"29 à sugestão de maior aparelhamento de polícias.

A demanda para providências de medidas repressivas é mundial. Tratados e Acordos assinados nos últimos dez anos têm clamado aos signatários que estabeleçam leis e regras (de caráter penal, civil e administrativo) para a prevenção e repressão da pornografia infantil. Alguns desses documentos são o Protocolo Facultativo à Convenção sobre os Direitos da Criança referente à Venda de Crianças, à Prostituição infantil e à Pornografia Infantil, das Nações Unidas (ratificado por 129 Estados, em 15 de novembro de 2008) a Convenção $n^{\circ}$ 182, da Organização Internacional do Trabalho (OIT), adotada em 1999, a Declaração e Agenda para Ação de Estocolmo (The Stockholm Agenda for Action against Commercial Sexual Exploitation of Children, 1996) e o Compromisso de Yokohama (Yokohama Global Commitment), sem falar nos documentos e recomendações produzidos pelo Conselho da Europa, como a Convenção sobre Cibercrime (Convention on Cybercrime) de Budapeste, também conhecida como Convenção de Budapeste (em vigor a partir de 2004) e as Diretrizes para Cooperação entre Provedores de Internet e Agentes da Lei contra o Cybercrime (Guidelines for the Cooperation between Law Enforcement and Internet Services Providers Against Cybercrime), adotadas em 2008 pelo Conselho da Europa.

\footnotetext{
${ }^{28}$ BRASIL. SENADO FEDERAL. CPI da Pedofilia na Internet. Relatório final. Brasília, Senado Federal, 2010. Disponível em http://www.senado.gov.br/atividade/materia/getPDF.asp?t=85380\&tp=1. Download em 17/12/2010.

${ }^{29}$ Este e outros termos utilizados para se referir a autores de violência sexual contra crianças e adolescentes foram objeto de análise no Capítulo 2, supra.
} 
Por exemplo, a Declaração do Rio de Janeiro para Prevenir e Eliminar a Exploração Sexual de Crianças e Adolescentes, já mencionada, recomenda a "adoção de medidas legislativas por mais Estados para fortalecer a proteção de crianças contra a exploração sexual, de acordo com obrigações internacionais, incluindo a promulgação de provisões legais para proteção de crianças vítimas de exploração sexual durante os processos de investigação criminal e julgamento de possíveis violadores, levando em consideração as Diretrizes das Nações Unidas sobre Justiça em Assuntos que Envolvam Crianças Vítimas e Testemunhas de Crimes ${ }^{30}$ ".

Dentre as observações e recomendações oriundas dos Grupos de Trabalho, a respeito da proteção de crianças e adolescentes no espaço cibernético ${ }^{31}$, constam recomendações a respeito da necessidade de avanços legislativos (complicado por conta do desenvolvimento contínuo da tecnologia); aprimoramento da cooperação entre países; ferramentas eficazes para a coleta e análise de informações de abuso sexual on-line; criação de unidades nacionais especializadas para o atendimento de vítimas e serviços de assistência aos infratores; treinamento de agentes da Lei; necessidade de maior informação ao público em sites e redes sociais a respeito dos riscos ou criação de sistema de bloqueio de informações etc.

Em meio às demandas por repressão, todavia, há demanda clara por prevenção, como aponta o Grupo de Trabalho supra citado, com relação à temática Autoproteção de crianças e adolescentes: há a necessidade de "implementação de programas de sensibilização para educar as crianças e pais sobre os riscos potenciais associados ao uso de novas tecnologias. O estímulo à utilização segura das novas tecnologias e comportamentos de autoproteção deve ser introduzido em todos os currículos nas escolas, juntamente com uma formação adequada dos professores"

A literatura estrangeira ${ }^{32}$ pesquisada também indica a necessidade da adoção de estratégias de prevenção com foco nas vítimas e também em seus familiares.

\footnotetext{
${ }^{30}$ Anais do III Congresso... Anexo III, p. 66

${ }^{31}$ Idem, p. 25.

${ }^{32}$ Cf, a respeito, SANZ MULAS, Nieves. Pornografia en internet. Revista Penal, Barcelona, n. 23, p.181202, jan. 2009; revisões bibliográficas densas realizadas apontam para a necessidade de mais estudos ligados à prevenção: CHOO, Kim-Kwang Raymond. Online child grooming: a literature review on the misuse of social networking sites for grooming children for sexual offences. Australian Institute of Criminology, 2009.
} 
"Iniciativas de educação amplas e focadas, que envolvem tanto as meninas quanto suas famílias nas localidades onde as meninas podem acessar seu mundo virtual, seriam um primeiro passo bastante positivo. Tais oportunidades de aprendizado poderiam desmistificar um pouco do mundo on-line para os pais, e ao mesmo tempo fornecer informações-chave para as meninas, abrindo um canal de comunicação bem-vindo entre as meninas e seus pais, que pode ser acessado sem medo de rejeição ou repreensão". ${ }^{33}$

Como se vê, a relevância da temática é inegável e há uma demanda social e dos formuladores de políticas públicas pelos estudos e pesquisas a respeito. A produção brasileira, todavia, ainda é incipiente, em especial nas ciências criminais, conforme se comprovou durante as pesquisas realizadas ao longo da presente pesquisa.

Nota-se a necessidade não só do fomento de medidas preventivas, num país cuja tradição é a política punitiva e repressora que, sabe-se, pouco faz no sentido de evitar a vitimização, atuando somente quando o mal já foi causado, mas também da sistematização de elementos teóricos para subsidiar o desenvolvimento de estratégias de prevenção.

É neste cenário que a presente pesquisa se justifica, pretendendo-se contribuir para a constituição de um corpo de saberes a respeito da violência sexual contra crianças $e$ adolescentes mediada pela TIC, propondo uma visão integrada da prevenção vitimal e do direito da criança e do adolescente.

Espera-se, ainda, que os elementos pesquisados possam subsidiar a elaboração de estratégias concretas de prevenção vitimal para o enfrentamento da violência sexual mediada pela TIC, de modo a contribuir para uma efetiva maior proteção de crianças e adolescentes face a esses desafios.

Disponível em http://aic.gov.au/crime_types/cybercrime/prevention.aspx; Youth Safety on a Living Internet: Report of the Online Safety and Technology Working Group. 2010, p. 66. Disponível em: http://www.ntia.doc.gov/reports/2010/OSTWG_Final_Report_060410.pdf; Enhancing Child Safety \& Online Technologies: Final Report of the Internet Safety Technical Task Force to the Multi-State Working Group on Social Networking of State Attorneys General of the United States," the Berkman Center for Internet \& Society at Harvard University, December 31, 2008.

${ }^{33}$ PLAN INTERNATIONAL. Because I Am A Girl: the State of the World's Girls 2010. Digital and Urban Frontiers: Girls in a Changing Landscape. London: Plan International, 2010, (tradutor nd), disponível em http://www.plan.org.br/publicacoes/download/adolescentes_brasileiras_mundo_digital.pdf; p. 133. 


\section{(iii) Método}

Para realizar os objetivos do presente trabalho, foi realizada revisão de literatura nacional e internacional a respeito dos seguintes temas: crimes sexuais contra criança e adolescente praticados por meio da tecnologia (pornografia infantil, abuso sexual on-line, aliciamento on-line entre outros); criminologia (especialmente a questão da figura do "pedófilo" e todo o estigma que o cerca); política criminal; prevenção criminal (especialmente prevenção vitimal); delitos sexuais e delitos cibernéticos; vitimologia (com foco nas vítimas de crimes sexuais e nas vítimas criança e adolescente); direitos humanos da criança e do adolescente na ordem internacional e interna - Convenção Internacional sobre os Direitos da Criança, Constituição Federal de 88 e Estatuto da Criança e do Adolescente; psicologia do desenvolvimento; psicanálise e ciências sociais.

A pesquisa foi realizada tanto presencialmente quanto on-line, em bibliotecas de universidades nacionais localizadas na cidade de São Paulo (como USP e PUC) e internacionais, quando o acervo se encontrava disponível on-line, bibliotecas especializadas (como a do Instituto Brasileiro de Ciências Criminais - IBCCrim). Além disso, material foi coletado em sites confiáveis na internet, como bancos de dados de trabalhos acadêmicos (como Scielo), sites de organismos internacionais - ONU, UNICEF etc - e sites específicos de institutos brasileiros e estrangeiros. Algumas obras de referência também foram adquiridas ou já eram parte de meu acervo.

Não há muita produção científica nacional a respeito da temática principal deste trabalho, em especial em publicações especializadas em direito penal e criminologia. $\mathrm{Na}$ pesquisa realizada no Brasil, foram localizados alguns materiais sobre bullying e cyberbullying, além de artigos sobre a vitimização de crianças e adolescentes no caso de crimes sexuais. Apesar da identificação, com relativa facilidade, de material a respeito de prevenção de abuso e exploração sexual de crianças e adolescentes e de prevenção criminal, escasso material científico foi localizado a respeito da prevenção da violência on-line e sobre prevenção vitimal. Em geral, os trabalhos acadêmicos em ciências criminais que foram localizados a respeito da violência sexual na internet abordam somente a "pedofilia", os "pedófilos" e a discussão a respeito da responsabilização de abusadores e de pessoas físicas que mantêm ou trocam conteúdo de pornografia infantojuvenil na rede mundial de computadores. 
Foram identificadas, também, monografias de jovens graduandos, o que parece indicar que o tema está despertando o interesse de jovens - pouco mais velhos do que as crianças e adolescentes sujeitos deste estudo. São trabalhos recentes, defendidos entre 2008 e 2011, o que indica que esta é uma preocupação crescente dos jovens pesquisadores, que conhecem o problema de perto e querem refletir sobre ele.

Com relativa facilidade encontra-se literatura técnica a respeito do tema violência sexual e TIC (muitas vezes inserido dentro de tema mais amplos, como dicas gerais de navegação segura, que vão além dos riscos da violência sexual) sob a forma de cartilhas, guias ou relatórios de projetos/programas. Vale dizer que, se alguns desses materiais expressam clichês e lugares comuns, reforçando a ideologia punitivista da lei e da ordem que costuma cercar a temática da violência sexual, é preciso salientar que uma parte não desprezível dos acadêmicos que estudam as questões da infância e juventude no Brasil compõem, direta ou indiretamente, o corpo técnico, consultivo ou diretivo de órgãos de formulação de políticas públicas para a infância e juventude, como o Conanda, e de organizações não governamentais de relevância na mesma área, como o Unicef. Isso explica, em parte, o fato de que as fontes de consulta do presente trabalho se constituem, em grande parte, de publicações dessas organizações governamentais ou não governamentais, documentos estes que, ao mesmo tempo em que são facilmente acessíveis para o público leigo (não acadêmico), constituem-se em material confiável para consulta, já que desenvolvidos pelos mesmos profissionais que têm realizado pesquisa acadêmica a respeito, como, por exemplo, é o caso de Benedito Rodrigues DOS SANTOS, consultor do Unicef, professor da Universidade Católica de Brasília e respeitado pesquisador da área, com doutorado e pós-doutorados em reconhecidas universidades estadunidenses, como Universidade Johns Hopkins e Universidade da Califórnia em Los Angeles.

Em outros países, especialmente nos anglo-saxões, como Estados Unidos, Inglaterra, Canadá e Austrália já há produção científica bem mais intensa, seja sobre a temática específica da violência sexual mediada pela TIC, seja sobre temas mais amplos, como a relação das crianças e adolescentes com a tecnologia. Um exemplo é o projeto interdisciplinar de pesquisa da Universidade de Harvard, denominado Digital Natives (Nativos Digitais) (http://cyber.law.harvard.edu/research/youthandmedia/digitalnatives), em colaboração com a Universidade de St Gallen, na Suíça, que pesquisa as práticas dos adolescentes no mundo digital e as intersecções dessas práticas com a educação e a lei. O 
projeto é composto por advogados, etnógrafos, sociólogos, especialistas em mídia, educadores e psicólogos especializados na interação humanos-computadores. O projeto busca "nutrir e proteger as possibilidades criativas, educacionais e revolucionárias das interações dos jovens no espaço digital e, ao mesmo tempo, responder às sérias preocupações que acompanham a vivência on-line".

O Instituto Australiano de Criminologia (Australian Institute of Criminology) também disponibiliza por meio de seu website (www.aic.gov.au) uma série de artigos produzidos por diversas instituições ao redor do mundo, razão pela qual foram coletados materiais ali; especialmente, foi utilizado um extenso e detalhado documento de revisão de literatura internacional a respeito do aliciamento on-line.

A produção acadêmica desses países é acompanhada por uma clara preocupação com a prevenção - tanto por parte de instituições do terceiro setor dedicadas à questão (como o inglês The Child Exploitation and On-line Protection Centre - CEOP http://ceop.police.uk/), quanto pelo governo (em nível nacional e regional - União Europeia); esta preocupação se reflete em campanhas e materiais educativos e informativos para diversos públicos-alvo, inclusive (e principalmente) adolescentes.

O tema estudado demandava a perspectiva interdisciplinar, necessária para, integrando saberes, oferecer uma vista panorâmica capaz de indicar caminhos para a ação. Adotada esta perspectiva, o que se propõe é a articulação das complexas apreciações teóricas relativas aos subtemas em que se divide o objeto principal, buscando-se "cobrir" os principais aspectos do problema.

Para estruturar a pesquisa, teórica, foi utilizado método dedutivo. Buscou-se a identificação de categorias de análise amplas que, posteriormente, são divididas em categorias pormenorizadas e abordadas de forma interdisciplinar. A interdisciplinaridade é a tônica, de modo que se buscou extrair, do material pesquisado, categorias que permitissem o diálogo entre saberes diversos.

O trabalho foi desenvolvido integralmente no Brasil sem o custeio de agências de fomento ou disponibilidade de tempo exclusivamente dedicado à pesquisa. 


\section{Parte I. Crianças e adolescentes, a sociedade em rede e a Tecnologia de Informação e Comunicação: riscos e benefícios.}

\section{Capítulo 1. Crianças e adolescentes e a (contraditória) sociedade em rede: mudanças e desafios.}

O que significa ser criança e ser adolescente na sociedade de hoje? Como são as vivências desses sujeitos no mundo globalizado e interconectado? Quais aspectos os diferenciam ou os aproximam dos jovens de gerações anteriores? Como se relacionam com as mídias e tecnologias, e qual o papel que a tecnologia da informação e comunicação (TIC) tem nas vidas desses sujeitos em desenvolvimento? Quais são os benefícios e os riscos inerentes às essas novas ferramentas?

Estas e outras perguntas mobilizam as atenções não apenas de pais e educadores, mas também de sociólogos, antropólogos, psicólogos, pesquisadores e operadores do direito.

Antes de nos debruçarmos sobre o objeto de estudo deste trabalho, considero necessário caracterizar o que é ser criança e ser adolescente na "sociedade em rede", que o sociólogo Manuel CASTELLS utiliza para se referir à sociedade atual ${ }^{34}$.

Para os fins desta caracterização, apoiar-me-ei nas ideias de CASTELLS, consubstanciadas na trilogia "A Era da Informação" e em obra mais recente, "A galáxia da Internet" 35 .

${ }^{34}$ A sociedade atual também é denominada, por outros autores, de sociedade tecnológica, pós-moderna, líquida, hipermoderna, sociedade da informação, etc.

${ }^{35}$ A opção pela concentração na obra de CASTELLS para a caracterização deste panorama deve-se, em primeiro lugar, ao fato de o autor preocupar-se em construir uma teoria sociológica compreensiva e não metafórica a respeito da sociedade pós-moderna identificando a comunicação como característica central desta revolução tecnológica. Parcelas significativas de sua trilogia são dedicadas à questão da sociabilidade on-line; o autor ainda produziu uma obra específica a respeito de um dos temas centrais deste trabalho, a TIC. Outros aportes teóricos da sociologia são trazidos, contudo, em outros momentos do trabalho, para a compreensão de questões mais específicas, como a sociabilidade adolescente e a construção social da temática da violência sexual e da "pedofilia".

CASTELLS, Manuel. A Era da Informação: economia, sociedade e cultura, vol. 1 (A Sociedade em rede), São Paulo: Paz e Terra, 1999.

. A Era da Informação: economia, sociedade e cultura, vol. 2 (O Poder da Identidade), São Paulo: Paz e Terra, 1999. Terra, 1999.

A Era da Informação: economia, sociedade e cultura, vol. 3 (Fim de Milênio), São Paulo: Paz e

. A galáxia da Internet: reflexões sobre a Internet, os negócios e a sociedade. Trad. Maria Luiza X. de A. Borges. Rio de Janeiro: Jorge Zahar, 2003. 244 p. 
Também são utilizados trabalhos de pesquisadores das áreas de sociologia e psicologia a respeito das vivências da infância e da adolescência na sociedade de hoje, grande parte deles contido em uma coletânea de artigos em quatro volumes denominada "O Olhar Adolescente", publicada em forma de revista, contando com colaboradores que são pesquisadores e professores das principais universidades do país.

A opção pela utilização destes trabalhos se dá não apenas pela propriedade de seus conteúdos, que dizem respeito diretamente ao tema deste trabalho, mas também porque a busca por obras que caracterizem a chamada "geração digital" resultou em raros resultados em termos de produção acadêmica, alguns deles inacessíveis nas condições de realização desta pesquisa ${ }^{36}$. Foram identificados, porém, alguns trabalhos publicados por pesquisadores da área em linguagem mais "palatável”, adaptada para a compreensão do leigo ${ }^{37}$. Apesar de concentrada em dados de pesquisas realizadas nos Estados Unidos, a obra "Crianças, adolescentes e mídia" ${ }^{38}$ que contém artigos de pesquisadores estadunidenses baseadas em extensas revisões de literatura, é bastante completa, razão pela qual também foi utilizada. Por fim, é utilizada também pesquisa recente publicada pelo UNICEF que se preocupou em ouvir crianças e adolescentes brasileiros, o que, neste trabalho, tem particular relevância, já que um dos pilares das ideias aqui apresentada é a participação de crianças e adolescentes .

A segunda parte do capítulo traz alguns dados quantitativos e qualitativos a respeito do uso da TIC por criança e adolescentes no Brasil, baseados em duas recentes pesquisas publicadas pelo Comitê Gestor da Internet no Brasil (CGI), pesquisa publicada pela ONG Safernet Brasil (Safernet) e pesquisas qualitativas realizadas no âmbito do Programa CPP, recentemente publicadas. Novamente, estas pesquisas têm como característica relevante o fato de terem se preocupado em ouvir diretamente as crianças e adolescentes, usuários de tecnologia, para saber como vivenciam o uso cotidiano da tecnologia.

\footnotetext{
${ }^{36}$ Por serem acessíveis somente em bibliotecas físicas localizadas em universidades distantes, dentro ou fora do Brasil.

${ }^{37}$ ARATANGY, Lidia Rosenberg. Adolescentes Na Era Digital. São Paulo: Benvirá, 2011.

${ }^{38}$ STRASBURGUER V.C.; WILSON, B. J.; JORDAN, A.B. (orgs). Crianças, adolescentes e mídia. Porto Alegre: Penso, 2011.
} 


\subsection{A sociedade em rede: comunicação, cultura e economia na era da informação.}

"Vivemos em tempos confusos, como muitas vezes é o caso em períodos de transição entre diferentes formas de sociedade". Assim o sociólogo espanhol Manuel CASTELLS inicia o prefácio à edição de 2010 de "A sociedade em rede", o primeiro volume de sua trilogia sobre "A Era da Informação", na qual o autor consubstancia uma proposta de desenvolver uma teoria social compreensiva, capaz de identificar as "tendências que caracterizam a estrutura e dinâmica das nossas sociedades no mundo do século XXI" "39 já que, em seu entender, há urgente necessidade de uma nova abordagem para a compreensão do tipo de economia, cultura e sociedade em que vivemos. Trata-se de extraordinário desafio, que o autor tem enfrentado desde a década de 1990 e que tem resultado em uma abordagem que, em meu entender, é bastante realista e, dentro de suas possibilidades e proposta, completa.

O desafio é complexo porque é complexa a tarefa de explicar qualquer sociedade sendo parte dela. E, hoje, mais ainda, pelo fato de que as mudanças estão acontecendo em uma velocidade jamais vista e vivida pelo ser humano.

As transformações pelas quais tem passado a humanidade a partir do final do século XX e início do século XXI são inúmeras e extremamente complexas. A sua mera descrição, no âmbito deste trabalho, já demandaria páginas e páginas e fugiria ao objetivo principal, que é analisar as vivências de crianças e adolescentes na sociedade atual e sua relação com a TIC. É óbvio, contudo, que essas vivências são afetadas, transformadas e, até certo ponto, determinadas por todas essas mudanças sociais, econômicas e culturais. Desse modo, elas serão apontadas quando necessário para contextualizar a caracterização que se pretende fazer.

Como ponto de partida coerente com o tema deste trabalho, serão trazidas as considerações que o autor faz a respeito do que ele considera ser o cerne das transformações que estamos vivendo: as tecnologias da informação, processamento $e$ comunicação. Estas considerações são também amarradas a uma visão a respeito das novas formas de sociabilidade que são construídas com base nestas transformações.

\footnotetext{
${ }^{39}$ CASTELLS, Manuel. A Era da Informação...vol. 1 (A Sociedade em rede)...”Prefácio à edição de 2010", p. III.
} 


\title{
1.1.1. Sociedade em rede: comunicação e sociabilidade.
}

A sensação de desorientação que domina as vivências na sociedade atual, acima apontada, é, em grande parte, segundo CASTELLS, formada por mudanças radicais no campo da comunicação, derivadas da revolução tecnológica aí ocorrida.

\begin{abstract}
"A passagem dos meios de comunicação de massa tradicionais para um sistema de redes horizontais de comunicação organizadas em torno da internet e da comunicação sem fio introduziu uma multiplicidade de padrões de comunicação na base de uma transformação cultural fundamental à medida que a virtualidade se torna uma dimensão essencial da nossa realidade. A construção de uma nova cultura baseada na comunicação multimodal e no processamento digital de informações cria um hiato geracional entre aqueles que nasceram antes da Era da Internet (1969) e aqueles que cresceram em um mundo digital". ${ }^{40}$ [destaquei]
\end{abstract}

A veloz revolução da tecnologia da informação ocorrida a partir do final do século XX se apresenta como um ponto de ruptura histórico que prepara o terreno para uma próxima era de estabilidade na história da vida e pode, sem exagero, ser equiparado à Revolução Industrial em termos de importância, por introduzir um padrão de descontinuidade nas bases materiais da economia, sociedade e cultura. A tecnologia de informação (TI) é, para esta revolução, o que as novas fontes de energia foram para as revoluções industriais sucessivas ${ }^{41}$.

\footnotetext{
${ }^{40}$ Idem, ibidem, p. II.

${ }^{41} \mathrm{O}$ autor alerta, porém, que não é o fato de a revolução atual ser essencialmente dependente de novos conhecimentos e informação que a torna diferente das demais. As duas revoluções industriais, por exemplo, dependeram de novos conhecimentos e do desenvolvimento de tecnologia (segundo o Dicionário Houaiss: "teoria geral e/ou estudo sistemático sobre técnicas, processos, métodos, meios e instrumentos de um ou mais ofícios ou domínios da atividade humana (p.ex., indústria, ciência etc.”). "O que caracteriza a atual revolução tecnológica, pois, é a aplicação desses conhecimentos e dessa informação para a geração de conhecimentos e de dispositivos de processamento/comunicação da informação, em um ciclo de realimentação cumulativo entre a inovação e seu uso. (...) O ciclo de realimentação entre a introdução de uma tecnologia, seus usos e seus desenvolvimentos em novos domínios torna-se muito mais rápido no novo paradigma tecnológico. (...) Há, por conseguinte, uma relação muito próxima entre os processos sociais de criação e manipulação de símbolos (a cultura da sociedade) e a capacidade de produzir e distribuir bens e serviços (as forças produtivas). Pela primeira vez na história, a mente humana é uma força direta de produção, não apenas um elemento decisivo no sistema produtivo. (...) Assim, computadores, sistemas de comunicação, decodificação e programação genética são todos amplificadores e extensões da mente humana". (destaquei) Idem, ibidem, p. 69.
} 
O que diferencia esta revolução das predecessoras é, entre outras coisas, a sua expansão global em uma velocidade sem precedentes. Enquanto a revolução industrial levou dois séculos para se expandir da Inglaterra e teve alcance limitado, as novas tecnologias da informação difundiram-se pelo globo em menos de duas décadas (1970 a 1990), por meio de sua aplicação imediata no próprio desenvolvimento da tecnologia $\operatorname{gerada}^{42}$. Como bem cantou o uruguaio Jorge Drexler, "Hay manos capaces de fabricar herramientas/Con las que se hacen máquinas para hacer ordenadores/ Que a su vez diseñan máquinas que hacen herramientas/Para que las use la mano"43. No mundo atual, o "trabalho manual" pode, em muitos casos, resumir-se ao digitar no teclado e à manipulação do mouse e das telas sensíveis ao toque (touch screens), entre outras ferramentas de interação digital.

As características deste novo paradigma ${ }^{44}$ são, em síntese, a informação como matéria-prima; a penetrabilidade dos efeitos da nova tecnologia; a lógica de redes; a flexibilidade (alta capacidade de reconfiguração sem destruir a organização) e a convergência de tecnologias específicas para um sistema altamente integrado. E a evolução desse paradigma, no entender do autor, não se dá em direção a seu fechamento como um sistema, mas rumo à abertura como uma rede de acessos múltiplos, sendo adaptável e aberto em seu desenvolvimento histórico ${ }^{45}$.

Se a lógica de redes é característica da Era da Informação, a internet é a sua base tecnológica. Esta forma organizacional, a rede, tem vantagens extraordinárias, em virtude de sua flexibilidade e adaptabilidade inerentes. No passado, as redes se restringiam ao domínio da vida privada (pensemos nas redes comunitárias/familiares de ajuda mútua para o cuidado com as crianças, ainda hoje existentes, em muitas comunidades). Hoje, três

\footnotetext{
${ }^{42} \mathrm{O}$ autor admite que ainda há grandes áreas do mundo e consideráveis segmentos da população que ainda estão desconectados desse novo sistema, espalhados por locais tão díspares quanto os subúrbios da França e as favelas africanas. Mas já há conexão em escala global de grupos sociais, atividades e territórios dominantes, sendo a falta de acesso à TI, hoje, um fator que caracteriza desigualdade.

43 "Guitarra Y Vos", Jorge Drexler.

44 Emprestamos a definição de Christopher Freeman, citada por CASTELLS (op. cit., p. 107): "Um paradigma econômico e tecnológico é um agrupamento de inovações técnicas, organizacionais e administrativas inter-relacionadas cujas vantagens devem ser descobertas não apenas em uma nova gama de produtos e sistemas, mas também e sobretudo na dinâmica da estrutura dos custos relativos de todos os possíveis insumos para a produção. Em cada novo paradigma, um insumo específico ou conjunto de insumos pode ser descrito como o 'fator-chave' (...). A mudança contemporânea de paradigma pode ser vista como uma transferência de tecnologia baseada principalmente em insumos baratos de energia para uma outra que se baseia predominantemente em insumos baratos de informação derivados do avanço da tecnologia em microeletrônica e telecomunicações".

${ }^{45}$ Idem, ibidem, p. 113.
} 
processos independentes se convergem em uma "nova estrutura social predominantemente baseada em redes: as exigências da economia por flexibilidade administrativa e por globalização do capital, da produção e do comércio; as demandas da sociedade, em que os valores da liberdade individual e da comunicação aberta tornaram-se supremos; e os avanços extraordinários na computação e nas telecomunicações possibilitados pela revolução microeletrônica" ${ }^{46}$, sendo a internet a alavanca da transição para a sociedade em rede e para uma nova economia.

O autor tem uma visão bastante clara a respeito das mudanças na mídia e em seus usos, que interessa aqui porque a TIC não se resume somente à internet. Apesar das claras diferenças entre a mídia de massas "tradicional", representada pela TV e pelo radio, e a internet, a World Wide $\mathrm{Web}^{47}$ (conhecida como www) e a comunicação sem fio, caracterizadas pelo autor como "meios para a comunicação interativa", "as fronteiras entre os meios de comunicação de massa e todas as outras formas de comunicação estão perdendo a nitidez".

Uma vez que qualquer conteúdo que possa ser digitalizado pode ser "jogado" na web (rede) - seja um documento escrito, vídeo, áudio ou software -, os conteúdos das demais mídias podem ser facilmente encontrados on-line, seja por meio de sua provisão “oficial” (grandes redes de TV já disponibilizam seu conteúdo integral ou parcialmente on-line, além de conteúdos "extra", e muitas emissoras de radio já podem ser ouvidas online em tempo real, de qualquer lugar do mundo), seja por meio da ação de usuários, que rapidamente disponibilizam conteúdos de TV ou radio on-line para outros usuários, por meio de diversos sites e programas de compartilhamento de vídeo e áudio ${ }^{48}$. Grandes jornais da mídia impressa também já disponibilizam todo seu conteúdo on-line (alguns somente para assinantes, porém, do mesmo modo que o vídeo e a música, basta "copiar e

\footnotetext{
${ }^{46}$ CASTELLS, Manoel. A galáxia da Internet..., p.8.

${ }^{47}$ Cf. glossário.

${ }^{48}$ Seriados norte-americanos que são veiculados com atraso no Brasil são facilmente "baixáveis" on-line em blogs ou fóruns específicos, sendo possível, em alguns casos baixar também legendas em português, um ou dois dias depois de sua exibição original nos EUA. Álbuns de música do mundo todo também são disponibilizados por meio de programas, blogs e fóruns on-line. Estas são as preocupações de gravadoras, estúdios, que, entre outras motivações, deram origem ao projeto de Lei do Congresso dos EUA conhecido pela sigla SOPA - Stop Online Piracy Act - que seria votado em janeiro de 2012 e que foi retirado de pauta pelo deputado federal proponente após semanas de protestos on-line.
} 
colar" o texto em um $\operatorname{blog}^{49}$ para que seja possível disponibilizar este conteúdo - que seria acessível somente mediante pagamento-, para toda a rede, sem custo algum).

A internet passou, portanto, a ser um meio para o acesso a todos os demais meios de comunicação de massa, com uma (entre muitas) diferença importante: não é possível restringir, por exemplo, horários de exibição. Enquanto, na TV, vigoram regras de classificação de programas (chamadas no Brasil de classificação indicativa) para orientação aos pais, e alguns programas têm horários de exibição restritos conforme o seu conteúdo, é possível, em qualquer horário do dia, assistir on-line à tradicional "novela das 8 " (somente exibida, atualmente, a partir das $21 \mathrm{~h}$, e que veicula temáticas mais dramáticas e pode conter cenas de violência e de conteúdo sexual).

\begin{abstract}
"A internet já transformou a televisão. Os adolescentes (...) nem entendem o conceito de assistir a televisão no horário determinado por outra pessoa. Eles assistem a programas inteiros de televisão na tela de seu computador e, cada vez mais, em dispositivos portáteis. (...) Portanto, a televisão continua sendo o principal meio de comunicação de massa, por enquanto, mas sua difusão e seu formato estão sendo transformados à medida que sua recepção vai se tornando individualizada". ${ }^{50}$ [destaquei]
\end{abstract}

Para CASTELLS, o desenvolvimento da chamada Web $2.0^{51}$ abriu caminho para "a formação de um sistema de comunicação digital multimodal e multicanal que integra todas as formas de mídia", e o "poder de comunicação e processamento de informações da internet está sendo distribuído em todas as áreas da vida social”, de modo que as pessoas constroem seus próprios sistemas de comunicação em massa, por meio, por exemplo, de sites como o Youtube ${ }^{52}$ que o autor não hesita em considerar como "o maior meio de comunicação de massa do mundo" ${ }^{, 53}$.

Dá-se, assim, um fenômeno denominado pelo autor de auto-comunicação de massa, que tem sido aproveitada pelas empresas para divulgar conteúdos, fortalecer

\footnotetext{
${ }^{49}$ Cf. Glossário.

${ }^{50}$ Idem, A Era da Informação...vol. 1 (A Sociedade em rede)...”Prefácio à edição de 2010”, p. XI.

${ }^{51}$ Web 2.0 é o "aglomerado de tecnologias, dispositivos e aplicações que dão suporta à proliferação de espaços sociais na internet graças ao aumento da capacidade da largura de banda, à difusão dos softwares de código aberto e à melhoria da parte gráfica e da interface dos computadores, inclusive a interação com avatares em espaços virtuais e tridimensionais". Idem, A Era da Informação... vol. 1 (A Sociedade em rede)..., Prefácio à edição de 2010, p. XII.

${ }^{52}$ Cf. Glossário.

${ }^{53}$ Idem, ibidem, p. XIII.
} 
marcas e vender produtos e serviços on-line: é comunicação de massa porque alcança potencialmente uma audiência global por meio da rede; é multimodal (o conteúdo pode ser reformatado e reproduzido e distribuído inclusive por meio das redes sem fio); e inclui com conteúdo autogerado, emissão autodirigida e recepção auto selecionada.

As mudanças da web 2.0 têm sido, ainda, potencializadas pelo crescimento da tecnologia de comunicação sem fio, que, segundo o autor, foi "a tecnologia de difusão mais rápida da história da comunicação. ${ }^{, 54}$ Em 2009, mais de $60 \%$ da população mundial já tinham acesso à comunicação sem fio, e a expansão desta tecnologia inclui as camadas mais pobres, que dão prioridade às suas necessidades de comunicação, usando, para satisfazê-las, parcela substancial de seus orçamentos.

Não é possível trazer aqui todas as análises que o autor faz a respeito da internet e de seu impacto na economia e nas próprias relações sociais. Tampouco é necessário contar a história de seu surgimento. Merece menção, porém, a abordagem de CASTELLS a respeito das novas formas de sociabilidade que começam a surgir a partir da revolução digital.

Algumas visões sugerem que a internet promoveria isolamento social, cortando os vínculos com o mundo real, ao mesmo tempo em que sua "condição de terra sem lei" ofereceria as condições para que as pessoas se comportem de maneiras totalmente diferentes das que se comportam no mundo real. Os laços criados por meio da rede não seriam reais. Será verdade?

Não (e, ao mesmo tempo, sim). O autor admite que o grau de sociabilidade que ocorre nas redes eletrônicas e as consequências culturais dessa nova forma de sociabilidade ainda não estão claros. Identifica, porém, pistas, a partir do trabalho de outros sociólogos e estudiosos da sociologia da internet ${ }^{55}$.

Esses autores demonstram que novas formas de sociabilidade, adaptadas ao novo meio ambiente tecnológico, estão surgindo on-line. Indicam também que, sim, há a criação de novas personalidades e identidades on-line e interpretação de papéis (que podem, segundo estudiosos, representar benefícios psíquicos para alguns sujeitos com dificuldades

\footnotetext{
${ }^{54}$ Idem, ibidem, p. X.

${ }^{55}$ Idem, A Era da Informação... vol. 1 (A Sociedade em rede)..., p. 443-446.
} 
de comunicação e de expressão, incluindo a sensação de pertencer a uma comunidade). Essas vivências virtuais, contudo, não são capazes de suprimir o fato de que, na vida real, o sujeito sofre. Além disso, aponta-se que há, sim, condições de uso da internet que aumentam a solidão, sensações de alienação e mesmo depressão ${ }^{56}$. Mas as respostas não se resumem a essas.

A formulação de CASTELLS, a respeito dessas novas formas de sociabilidade parte do conceito de comunidades pessoais formulado por Barry WELLMAN, apontado como o maior dos sociólogos da internet: "a rede social do indivíduo de laços interpessoais informais, que vão de meia-dúzia de amigos íntimos a centenas de laços mais fracos (...)".

Em uma sociedade que não mais se estrutura primordialmente a partir de grupos comunitários que, no passado, permaneciam unidos por laços diversos, como o sangue, a religião, a terra, ou a cultura, mas que tem no indivíduo o seu eixo central, as redes virtuais são a projeção, potencializada, do que já acontece na vida real: “assim como nas redes físicas pessoais, a maioria dos vínculos das comunidades virtuais são especializados e diversificados, conforme as pessoas vão criando seus próprios 'portfolios pessoais'. Os usuários da Internet ingressam em redes ou grupos on-line com base em interesses em comum, e valores, e já que têm interesses multidimensionais, também o terão suas afiliações on-line. Não obstante, com o passar do tempo, muitas redes que começam como instrumentais e especializadas acabam oferecendo apoio pessoal"57.

Sobre os tipos de uso da internet, o autor aponta que, para os adultos, o uso da rede é primordialmente instrumental (o email ligado a objetivos de trabalho, contato com a família e amigos representa mais de $85 \%$ do uso da rede), enquanto que as práticas dos adolescentes incluem também a representação social e a construção de identidade como base da interação on-line.

\footnotetext{
${ }^{56} \mathrm{O}$ autor alerta para o fato de que o debate a respeito dessas questões foi prejudicado, entre outros, pela ausência de um corpo substancial de pesquisa empírica confiável a respeito dos usos reais da internet. Além disso, se baseou, inicialmente, em uma visão que o autor classifica como idílica a respeito das comunidades pré-internet (harmoniosas, coesas, etc), que se opõe a uma visão igualmente estereotipada a respeito do usuário da internet.

${ }^{57}$ Idem, A Era da Informação... vol. 1 (A Sociedade em rede)..., p. 444.
} 
Mesmo assim, as representações de papéis não parecem constituir uma proporção significativa da sociabilidade baseada na internet ${ }^{58}$. Os usuários da rede têm uma clara noção do que é real e do que é virtual, inclusive os adolescentes. Os estudos citados pelo autor dão conta que as personalidades criadas on-line correspondem, em grande medida, às identidades off-line.

O autor aponta ainda que a interação social on-line "não parece ter um efeito direto sobre a configuração da vida cotidiana em geral, exceto por adicionar interação on-line às relações sociais existentes" ${ }^{\prime \prime}$. Não haveria diferenças significativas entre o comportamento social de usuários e não usuários.

O que a internet parece fazer é adicionar novas possibilidades às interações sociais, permitindo a manutenção de laços com pessoas (amigos ou conhecidos) que moram longe e a ter uma vida social longe de casa. Parece que usuários de internet tendem a ter uma rede social mais dispersa do que não usuários. Assim, o uso da internet parece reforçar a criação e manutenção de laços fortes, seja com amigos e familiares próximos, seja com aqueles que vivem a grandes distâncias, seja com os amigos mais próximos: o uso do email contribui para a interação face-a-face, não substituindo outras formas de interação social; além disso, atualmente é possível ter diariamente interação social on-line com qualquer pessoa em qualquer lugar do mundo, bastando para isso que se tenha uma conexão de internet em banda larga, um computador com câmera e microfone, e um programa adequado para conversar em vídeo ou voz, que pode ser baixado gratuitamente.

Por outro lado, segundo CASTELLS, nota-se um aumento dos vínculos sociais fracos múltiplos. Esses laços facilitam a ligação de pessoas com diversas características sociais, e são úteis especialmente para a troca de informações e abertura de novas oportunidades. Para a criação de um laço fraco on-line, basta um único ponto ou interesse comum. Pessoas com orientações políticas absolutamente opostas, pertencentes a classes sociais diversas e situadas em locais diferentes do mundo podem criar laços fracos a partir de um hobby comum. E as comunidades virtuais criadas em torno desses específicos pontos em comum podem ser mais fortes do que se imagina, proporcionando

\footnotetext{
${ }^{58}$ Idem, A Galáxia... p. 99-100; A Era da Informação... vol. 1 (A Sociedade em rede), p. 445.

${ }^{59}$ Idem, A Galáxia... p. 100-101.
} 
oportunidades para o exercício de solidariedade recíproca, alimentadas pela liberdade de expressão e pelas oportunidades de discussões desinibidas oferecidas pela rede.

Desse modo, as comunidades virtuais formadas pela internet não seguem os mesmos modelos de comunicação e interação das comunidades físicas. "São redes sociais interpessoais, em sua maioria baseadas em laços fracos, diversificadíssimas e especializadíssimas, também capazes de gerar reciprocidade e apoio por intermédio da dinâmica da interação sustentada. (...) Não existem no isolamento de outras formas de sociabilidade. Reforçam a tendência de 'privatização da sociabilidade' - isto é, a reconstrução das redes sociais ao redor do indivíduo, o desenvolvimento de comunidades pessoais, tanto fisicamente quanto on-line. Os vínculos cibernéticos oferecem a oportunidade de vínculos sociais para pessoas que, caso contrário, viveriam vidas sociais mais limitadas, pois seus vínculos estão cada vez mais espacialmente dispersos"60.

Se, conforme aponta CASTELLS (já citado acima), a interação social on-line não parece afetar a configuração da vida cotidiana em geral, "exceto por adicionar interação on-line às relações sociais existentes"; ao mesmo tempo, como se vê, a configuração dessas relações sociais está mudando a partir da revolução tecnológica - do mesmo modo que as relações econômicas e a cultura.

Assim, "para centenas de milhões de usuários de internet com menos de trinta anos de idade, as comunidades on-line se tornaram uma dimensão fundamental da vida cotidiana que continua a crescer em toda parte", e essas comunidades não se desenvolvem como um mundo virtual à parte, "mas como uma virtualidade real integrada a outras formas de interação em uma vida cotidiana cada vez mais híbrida" ${ }^{61}$, configurando-se, portanto, como uma cultura da virtualidade real. [destaquei]

\footnotetext{
${ }^{60}$ A Era da Informação... vol. 1 (A Sociedade em rede), p. 446. Estas análises vêm conectadas, na formulação teórica do autor, com uma série de outras concepções, como, por exemplo, as transformações que sofrem as próprias experiências do tempo ("o tempo atemporal"; a busca da "simultaneidade perene e ubiquidade simultânea", estimuladas pela "miragem da transcendência do tempo" proporcionada pela disponibilidade das novas TIC) e do espaço na vida humana, transformações estas que têm se dado com maior força nas grandes cidades (cidades informacionais). O "espaço de fluxos" é a nova forma de espacialidade, transformada pela simultaneidade, característica do tempo presente; é o "suporte material de práticas sociais simultâneas comunicadas à distância", o que envolve a produção, transmissão e processamento de fluxos de informação e implica na conexão de rede entre o global e o local, funcionando as grandes cidades como "nós" da rede. Para maiores detalhes, cf. A Era da Informação... vol. 1 (A Sociedade em rede), Prefácio à edição de 2010, p XVI-XXIX e Capítulo 7.

${ }^{61}$ Idem, ibidem, p. XV.
} 


\subsubsection{Sociedade em rede: mudanças estruturais em curso.}

As mudanças na comunicação e o consequente desenvolvimento de uma nova forma de sociabilidade estão claramente ligadas a diversas outras mudanças sociais muito mais profundas, como as ocorridas na economia e na estrutura familiar tradicional (ao menos, no mundo ocidental). Com relação a esta última, CASTELLS aponta para o que denomina de crise da família patriarcal, ou seja, "o enfraquecimento do modelo familiar baseado na autoridade/dominação contínua exercida pelo homem, como cabeça do casal, sobre toda a família”. Essa crise indica o fim da família como a conhecemos até agora (família nuclear e patriarcal) e é evidenciada pela dissolução dos lares, o que leva à formação de lares de solteiros ou lares com apenas um dos pais; pelo adiamento da formação de casais e formação de relacionamentos sem casamento; pelo surgimento de grande variedade de estruturas domésticas; e pela crise dos padrões sociais de reposição populacional $^{62}$.

A transformação no modelo familiar patriarcal ocorre impulsionada pela transformação da economia e do mercado de trabalho e da abertura de oportunidades para as mulheres; pelas transformações tecnológicas que proporcionaram controle sobre a reprodução humana; pelo desenvolvimento do movimento feminista partir do final da década de 1960 e pela rápida difusão de ideias em uma cultura globalizada. A revolução na sexualidade, que deixa de ser ligada ao casamento, à família e à heterossexualidade, também é um fator apontado pelo autor como parte da crise do patriarcalismo.

Essas mudanças tiveram e têm tido impacto significativo nas relações entre pais e filhos, o que vem sendo constatado, entre outras coisas, por uma comumente apontada "crise de valores" na sociedade. Essa suposta crise se verifica de modo simples na sociedade brasileira: basta lembrar a já conhecida "briga" de responsabilidades entre família e escola, em que as famílias acusam a escola de não educar seus filhos, enquanto que a escola responde que "educação" (no sentido de valores, de respeito ao próximo, ou seja, regras morais básicas de convivência) se ensina em casa.

De todo modo, como se verá adiante, a mudança na família tradicional patriarcal, vem acompanhada das mudanças sociais introduzidas pela tecnologia. Hoje, grande parte

\footnotetext{
${ }^{62}$ CASTELLS, Manuel. A Era da Informação..., vol. 2 (O Poder da Identidade); cap. 4.
} 
das mulheres trabalha fora de casa. Isso significa pais e mães passando cada vez menos tempo com seus filhos, que ficam sob a tutela de babás, de outros familiares, ou na creche/escola, desde a mais tenra idade. Ainda que não se faça qualquer juízo de valor a respeito, é inegável que a mudança na estrutura familiar tradicional trará efeitos para as relações sociais de modo mais amplo. E, sem sombra de dúvidas, tem efeitos nas próprias relações familiares e no controle que os pais exercem sobre as atividades dos filhos dentro e fora de casa. Essas questões aparecem claramente nas falas de crianças e adolescentes, quando entrevistados a respeito do uso de tecnologia, conforme ficará claro mais adiante.

As mudanças culturais e sociais identificadas por CASTELLS, aqui brevemente visitadas, são vivenciadas no mundo todo (em maior ou menor proporção e, evidentemente, com as peculiaridades culturais de cada local). E, apesar de os membros das classes sociais mais altas terem acesso privilegiado às novidades tecnológicas, elas rapidamente são adaptadas para distribuição a custo mais acessível e integradas ao cotidiano das pessoas de todas as classes, muitas vezes de modo não antevisto pelos empresários ${ }^{63}$.

As crianças e, principalmente, os adolescentes, têm sido ativos e criativos protagonistas dessas mudanças. Ao contrário dos adultos, que tiveram que se adaptar ao uso do computador e da internet, essas crianças e adolescentes são chamados por alguns pesquisadores de nativos digitais, pois desde o nascimento convivem com a linguagem da internet, o multimídia, a comunicação sem fio etc. Novamente, sabe-se que não são todas as crianças que têm acesso aos computadores e internet desde a primeira infância ${ }^{64}$, mas é fato que, uma vez iniciado o contato, rapidamente dominam a tecnologia, dela se apropriam e a transformam.

\footnotetext{
${ }^{63}$ Um exemplo foi a rápida difusão do celular, no Brasil, a partir do lançamento das linhas pré-pagas. O celular pré-pago representou a possibilidade de comunicação para milhares de pessoas que, até então, não tinham telefone próprio (fixo ou celular). Rapidamente, profissionais autônomos adquiriram seus aparelhos para poderem ser contatados por clientes, o que permitiu a expansão de seus negócios. O que, parece, as empresas de telefonia não previram, era que muitos desses usuários utilizariam o celular primordialmente para receber ligações - a linha pré-paga, sem conta fixa, significava a possibilidade de ser contatado por terceiros a custos irrisórios. Em "contra-ataque", as empresas de telefonia passaram a atribuir prazos máximos para o uso dos créditos adquiridos (o que não acontece em outros países), obrigando os consumidores a utilizar os créditos em prazos curtos (1 ou 2 meses), além de fazer recargas, sob pena de perda dos créditos e de desativação da linha. Somente em 2007 a Agência Nacional de Telecomunicações determinou a proibição da perda dos créditos e o prazo mínimo de 180 dias para o seu uso.

${ }^{64} \mathrm{Cf}$, dados a respeito da realidade do Brasil, atualizados, mais adiante.
} 


\subsubsection{Sociedade em rede: capitalismo informacional e violência contra crianças e adolescentes}

Ao mesmo tempo em que os nativos digitais usam cotidianamente a tecnologia e têm acesso a todos os demais benefícios trazidos pelo progresso científico (como os avanços da medicina), outras crianças e adolescentes, no mundo todo, sofrem com a exploração sexual ou são usadas como "mão-de-obra pronta para uso e descartável" ${ }^{65}$, no âmbito do capitalismo global em rede. Esta é só uma de tantas contradições que vivemos na Era da Informação.

Há uma relação sistêmica, ainda não adequadamente estudada, entre as características atuais do capitalismo informacional e a destruição de vidas em um grande segmento da população infantil do mundo. Alguns dos fatores que apontam para esta relação são: desregulamentação em larga escala e a imunidade das redes globais em relação às medidas e controles governamentais; desintegração das sociedades tradicionais e do patriarcalismo; turismo global e sua relação com a exploração sexual e com a pornografia infantil; fragilização das instituições de defesa dos direitos da criança ${ }^{66}$.

É clara, porém, para CASTELLS, a associação sistêmica entre a estrutura social específica do capitalismo informacional e a superexploração e os abusos praticados contra crianças. "No cerne da exploração infantil encontram-se os mecanismos geradores de pobreza e exclusão social em todo o mundo", sendo a venda ou fuga de crianças somente uma das expressões de diversas reações-limite a situações de extrema pobreza, desde a África subsaariana até os EUA. Maus-tratos, abuso e exploração sexual, negligência são algumas das formas de "desperdício das crianças" citadas pelo autor, ligadas a estruturas familiares enfraquecidas e a infâncias empobrecidas.

A globalização, a formação de redes empresariais e a criminalização de determinados segmentos da economia, as avançadas tecnologias de comunicação absorvem a oferta de crianças cuja infância é desperdiçada na forma de trabalho infantil, exploração sexual e maus tratos em geral.

\footnotetext{
${ }^{65}$ CASTELLS, Manuel. A Era da Informação..., vol. 3 (Fim de Milênio), p. 183.

${ }^{66}$ Idem, ibidem, p. 188.
} 
O trabalho infantil é parte integrante das engrenagens que movem o capitalismo informacional, caracterizado, por um lado, pelo investimento cada vez maior no desenvolvimento de marcas (branding) e no design e desenvolvimento de produtos e, por outro lado, pela terceirização e quarteirização da produção para empresas situadas em países pobres, onde a mão-de-obra é barata e as condições de trabalho, subumanas. Indonésia, Camboja, Vietnã são alguns dos países-símbolo de trabalhadores escravos ou em situação análoga à de escravo e de exploração de trabalho infantil, produzindo eletrônicos e roupas que serão vendidos em grandes lojas de departamento nos Estados Unidos (e, hoje, também no Brasil ${ }^{67}$.

A exploração sexual de crianças é considerada pelo autor como a última fronteira da superexploração de crianças (mão-de-obra barata, pronta para uso e descartável) no capitalismo informacional em rede: "elas se tornaram mercadorias sexuais em uma indústria de larga escala, organizada internacionalmente através do uso de tecnologia avançada, e que tira proveito da globalização do turismo e das imagens" ${ }^{68}$.

Disseminada pelo globo, seja em países pobres, em desenvolvimento ou desenvolvidos (Tailândia, Índia, Sri Lanka, Brasil, Peru, EUA e Canadá são alguns dos países citados por CASTELLS como campeões de exploração sexual infantojuvenil em números absolutos), a pornografia infantil é considerada um segmento da "indústria do sexo de menores" em franca expansão, graças ao desenvolvimento tecnológico, que possibilita a circulação gratuita, rápida e sigilosa de imagens de pornografia on-line, e abre canais de acesso a crianças e adolescentes que usam a rede com pouca orientação e supervisão. O anonimato e a globalização dos mercados alimentam a demanda, e a oferta se dá num contexto alimentado por estruturas familiares enfraquecidas e pobreza ${ }^{69}$.

Crianças e adolescentes brasileiras, de todas as origens e classes sociais, navegam no ambiente profundamente contraditório da sociedade em rede, no contexto de uma cultura da urgência ${ }^{70}$, conceito que converge com o de cultura da vaidade, anteriormente

\footnotetext{
${ }^{67}$ Obra de referência que descreve, detalhadamente, como funciona este sistema em escala global é "Sem logo: a tirania das marcas em um planeta vendido", da jornalista, escritora e ativista canadense Naomi KLEIN, publicado em português pela Editora Record, em 2002.

${ }^{68}$ CASTELLS, op cit, p. 183.

${ }^{69}$ Idem, ibidem, p. 185-186.

${ }^{70}$ Idem, Ibidem, p. 190.
} 
referida $^{71}$. Na sociedade do hiperconsumo individualizado, não há futuro nem raízes, somente o agora, o presente, que precisa ser "curtido" e consumido até a última gota.

Disseminada nas sociedades ocidentais e orientais atuais, a cultura da urgência adquire contornos particularmente dramáticos quando a identificamos entre crianças em situação de abandono, risco, negligência, maus-tratos: no Brasil, alguns de seus maiores porta-vozes são as crianças e adolescentes envolvidas desde muito pequenas no tráfico de entorpecentes, identificadas por pesquisadores como VICENTIN ${ }^{72}$ ("Eu não nasci pra semente", diz, de forma emblemática, um dos entrevistados, internado na extinta Febem).

O mais recente gadget tecnológico e a exploração sexual, os nativos digitais e as crianças desperdiçadas são faces da mesma moeda - a moeda que financia o capitalismo global/informacional na sociedade em rede. Este é o contraditório pano de fundo em que se situa o objeto da presente pesquisa.

\subsection{Infâncias e Adolescências na sociedade em rede.}

Visto de longe, o panorama parece, ao mesmo tempo, promissor e assustador. É preciso aproximar-se um pouco mais para que seja possível identificar suas nuances. É necessário olhar para as crianças e adolescentes inseridos nesta sociedade, identificando o que há de comum entre elas, mas também o que as diferencia; suas vivências no uso da TIC, mas também as condições em que vivem em termos de economia, cultura e sociedade.

Cada um desses temas, isoladamente, já se apresenta como objeto para inúmeros tratados, estudos e pesquisas. Aqui, o que se busca é um segundo pano de fundo, ainda um pouco difuso mas alguns passos mais perto do público, a partir do qual seja possível olhar um pouco mais de perto as questões (desafios, oportunidades) que as novas TIC trazem para a vida de crianças, e a interação de suas condições de vida off-line com a sua vivência on-line.

${ }^{71}$ LA TAILLE, Yves de. Crise de Valores...

72 Maria Cristina VICENTIN (A vida em rebelião: historias de jovens em conflito com a lei. Tese (Doutorado em Psicologia Clínica). São Paulo: Pontifícia Universidade Católica de São Paulo, 2002). 
Valores, usos e costumes de crianças e adolescentes, semelhanças e diferenças entre classes e realidades sociais diferentes são enfocados, dentro das limitações a que se restringe este trabalho. Dados qualitativos e quantitativos a respeito dos usos da TIC, das oportunidades e angústias a ela associadas são apresentados a seguir.

\subsubsection{Infâncias e adolescências na sociedade em rede: cultura e valores na realidade brasileira.}

Antes de caracterizar algumas vivências de crianças e adolescentes na sociedade em rede, é importante registrar algumas observações a respeito dos conceitos de infância e, especialmente, de adolescência, conceitos esses que foram socialmente construídos ${ }^{73}$. Foi somente a partir do trabalho de historiadores como Philippe ARIÈS ${ }^{74}$ que se identificou que as crianças demoraram a ser reconhecidas como uma categoria à parte (somente a partir do século XVI) e que há uma mudança na visão social a respeito das crianças: antes, consideradas "mini-adultos", e posteriormente identificadas como necessitadas de mais proteção e como seres humanos nos quais é necessário "investir" (na formação, educação etc).

Segundo DEL PRIORE ${ }^{75}$, são duas as teses de Ariès que revolucionam o tema da história das crianças: - a escolarização, iniciada na Europa a partir do século XVI, provoca uma metamorfose na formação moral e espiritual das crianças (passa-se a preparar as crianças para o futuro); - a família passou por profunda transformação, com a emergência da vida privada e a valorização do foro íntimo ${ }^{76}$.

A diferenciação se torna mais específica a partir do século XVIII, quando se estabelece um sistema de ensino diferenciado para os filhos da classe burguesa (que faziam o "primário" e o "secundário" - colégio), sendo que para os filhos "do povo" era reservado somente o "primário". A diferenciação entre crianças e adolescentes ganha força

\footnotetext{
${ }^{73}$ Enquanto na Parte II deste trabalho busca-se caracterizar crianças e adolescentes a partir da perspectiva jurídica e biopsicológica, o presente capítulo busca a visão sociológica para a sociedade em rede e para as vivências de crianças e adolescentes nesta sociedade.

${ }^{74}$ Seus primeiros estudos sobre a questão foram publicados a partir de 1948; sendo o mais conhecido "A criança e a família no Antigo Regime", publicado em 1960. O autor é frequentemente referenciado nos estudos de autores brasileiros sobre a infância e a juventude.

${ }^{75}$ DEL PRIORE, Mary. (org.). História das Crianças no Brasil. São Paulo: Contexto, 2006; p. 7-17 (apresentação).

${ }^{76}$ Do mesmo modo, conforme exposto no item anterior, CASTELLS identifica uma mudança na família na sociedade pós-moderna.
} 
com o desenvolvimento científico (incluindo-se, aí, a psicologia), que passa a identificar as mudanças biológicas (neurológicas, hormonais etc) e psicológicas pelas quais passam os seres humanos a partir da puberdade ${ }^{77}$.

A visão biopsicológica pura tem o mérito de identificar fenômenos e tendências gerais ou universais referentes a crianças e adolescentes e estabelece importantes parâmetros mínimos que justificam a legislação protetiva para crianças e adolescentes. A esta visão, porém, faltam nuances que são trazidas pelas ciências sociais, que contextualizam as vivências de crianças e adolescentes na sociedade e identificam diferenças culturais, econômicas, sociais que têm impacto significativo nas suas experiências de vida e no seu desenvolvimento, de modo que, atualmente, fala-se não mais em adolescência, mas em adolescências.

A própria ideia da adolescência como fase de conflitos, que vem ancorada nas descobertas científicas a respeito das mudanças biológicas que ocorrem a partir da puberdade, é questionada. Se é verdade que, como se verá adiante, as mudanças hormonais e neuronais provocam reviravoltas no corpo infantil, e que tais mudanças estão atreladas à capacidade de aprendizagem de conceitos, ao desenvolvimento motor e moral, também é verdade que os adolescentes passam por este período com maior ou menor possibilidade de vivenciar a experimentação e a rebeldia sem grandes consequências. Para muitos adolescentes, contudo, aponta OZZELLA, a realidade não permite as irresponsabilidades ou inconsequências comumente associadas a este período da vida:

\footnotetext{
"Em 2008, publiquei uma pesquisa, com quase mil jovens, de classes A a E, de diferentes raças/etnias, meninos e meninas. Há uma diferença muito grande entre jovens de origens diferentes; são adolescentes completamente diferentes, ainda mais se considerados gênero e classe social. Em relação à classe social, você encontra formas diferentes de viver a adolescência. Jovens de classes A e B reafirmam que o adolescente em geral é irresponsável. Mas, nas classes $C, D$ e E, quando você pergunta como o adolescente é, ele é completamente diferentepreocupado com a família, com o trabalho. Ele tem uma visão de adolescente construída na própria vida, não a tradicional da literatura. Essa visão do adolescente "cuca-fresca" passa para os adolescentes de classe baixa um sofrimento - eles sofrem porque não são como os adolescentes mostrados na televisão. $\mathrm{O}$ jovem de classe baixa tem a carência de não ter vivido o que parece ser a adolescência. Ele sofre com isso. Eles dizem
}

\footnotetext{
${ }^{77}$ A respeito, cf. Capítulos 3 e 4, adiante.
} 
claramente: "Eu não tive adolescência, não consegui ser assim, não tive essa liberdade que a gente vê". Na classe $\mathrm{D}$, o adolescente tem que ser responsável, tem que começar a trabalhar, pensar na sua família." ${ }^{" 78}$ [destaquei]

Desse modo, as experiências de crianças e adolescentes na sociedade em rede serão diferentes conforme as diferenças que experimentam em seus cotidianos.

Nota-se, na literatura pesquisada, que grande parte dos perfis traçados a respeito de crianças e adolescentes e sua relação com a mídia tradicional de massa e com as novas tecnologias é baseada em pesquisas feitas com adolescentes de classe média e alta, que, de fato, já nasceram "conectados": os nativos digitais (digital natives ${ }^{79}$ ).

Os nativos digitais são caracterizados como crianças que nasceram em um mundo tecnológico e convivem com aparelhos eletrônicos desde a mais tenra idade, sendo capaz de interagir com eles desde muito cedo ${ }^{80}$. Quando crescem, tornam-se adolescentes "multitarefeiros", capazes de manejar simultaneamente várias ferramentas tecnológicas: "Muitos adolescentes são capazes de usar o computador, falar ao telefone e ouvir rádio ao mesmo tempo. Hafner (2001) descreve uma adolescente que fazia um trabalho da escola, buscava informações na web, verificava seus e-mails, mantinha aberta até oito janelas de

78 UNICEF. $O$ direito de ser adolescente: Oportunidade para reduzir vulnerabilidades e superar desigualdades. Brasília: UNICEF, 2011; p. 17-18 (entrevista com Sérgio Ozzella). O psicólogo social, pesquisador e ex-professor da PUC faz referência à pesquisa cujos resultados foram discutidos no artigo assinado por Sérgio OZZELLA e Wanda Maria Junqueira de AGUIAR, "Desmistificando a Concepção de Adolescência” publicado em Cadernos de Pesquisa, v. 38, n. 133, p. 97-125, jan./abr. 2008, disponível em http://www.scielo.br/pdf/cp/v38n133/a05v38n133.pdf.

${ }^{79}$ Há uma colaboração acadêmica interdisciplinar liderada pela universidade de Harvard, em colaboração com a Universidade de St. Gallen na Suíça e o Berkman Center, dedicado especialmente ao estudo dos nativos digitais e que se dedica a "pesquisar as práticas digitais do jovens e a interseção entre esses comportamentos e a educação e a lei". O grupo de pesquisa é formado por advogados, etnógrafos, sociólogos, estudiosos de mídia, educadores e psicólogos que pesquisam a interação homem-computador. O foco do grupo são as implicações legais, sociais e políticas de uma geração que já "nasceu digital" "aqueles que cresceram imersos nas tecnologias digitais, para os quais uma vida totalmente integrada com dispositivos digitais é algo normal" (tradução livre da autora). Mais informações podem ser obtidas em http://cyber.law.harvard.edu/research/youthandmedia/digitalnatives

${ }^{80}$ Com a disseminação de aparelhos eletrônicos com telas sensíveis ao toque (touch screen), já ouvi de um pai, usuário cotidiano de computador e tablet o relato sobre as tentativas de interação de sua filha - de menos de 1 ano de idade - com um tablet, tocando a tela de modo experimental (imitando o pai). Este mesmo pai, por viajar muito a trabalho, comunica-se frequentemente com a família por meio de programas para conversar à distância, como o Skype. Assim, desde os 2 meses de idade, quando seu pai viajou pela primeira vez após seu nascimento, esta criança já vem se habituando a interagir (e conversar, quando atingiu a idade adequada) com o pai por meio da tela de um computador, quando ele não pode estar presente fisicamente. Relato semelhante pode ser encontrado na matéria do UOL citada logo ao início da introdução (IKEDA, Ana. Autodidatas da tecnologia, crianças ignoram bê-á-bá da segurança online. UOL Tecnologia. 02/08/2010. Disponível em http://tecnologia.uol.com.br/seguranca/ultimas-noticias/2010/08/02/autodidatasda-tecnologia-criancas-ignoram-be-a-ba-da-seguranca-online.jhtm, consulta em 04/10/2011). 
messenger, envolvia-se em conversas on-line com os amigos e ouvia seu MP3 player e um cd de música." 81

Não são somente os nativos digitais, porém, que têm acesso e usam a tecnologia. Crianças e adolescentes das classes sociais mais baixas, que usam a internet nas lan houses e cujos pais são considerados iletrados digitais vivenciam experiências, ao mesmo tempo, semelhantes e diferentes às retratadas em livros e divulgadas pela mídia em revistas populares. Mais adiante, são apresentados dados que incluem a oitiva de crianças e adolescentes oriundos de realidades sociais tão diversas quanto o Maranhão e São Paulo.

Mesmo havendo poucas pesquisas no Brasil a respeito do uso da TIC por crianças e adolescentes, pesquisas com enfoque mais amplo se preocupam em ouvir sujeitos de diferentes classes sociais e dão pistas de algumas das diferenças e semelhanças, ajudando a entender o que significa ser criança e adolescente hoje. Por exemplo, uma investigação conduzida por TOGNETTA e VINHA ouviu 150 meninos e meninas entre 14 e 16 anos, estudantes de escolas públicas e privadas de uma cidade do interior paulista a respeito de quais são os valores ${ }^{82}$ importantes para eles, no âmbito do estudo sobre o desenvolvimento moral, a partir de uma categoria central: a indignação.

$\mathrm{Na}$ categorização das respostas, notam-se diferenças claras entre os resultados das escolas pública e privada. Assim, quando perguntados a respeito da pergunta única "existe alguma coisa que as pessoas fazem que deixa você com raiva ou indignado?", as respostas agrupadas sob a categoria "rejeição" aparecem em 10,53\% das respostas na escola pública, e em zero repostas na escola privada. Os autores da pesquisa inferem que, talvez, na escola particular os estudantes encontrem mais abertura para o convívio entre pares do que na escola pública. "Parece haver uma crença entre muitos professores de escolas públicas de que o autoritarismo de suas ações é a maneira mais efetiva de regular as relações que têm com os alunos e que, portanto, trabalhos ou conversas em grupo são 'perda de tempo"”, ${ }^{83}$

${ }^{81}$ SINGER, Dorothy G. "Introdução". In: Crianças, adolescentes e mídia. STRASBURGUER V.C.; WILSON, B. J.; JORDAN, A.B. (orgs). Porto Alegre: Penso, 2011, pg.19.; No mesmo sentido, ARATANGY, op cit, p.40 ("nossos jovens são capazes de se ocupar simultaneamente com atividades múltiplas e diferentes").

${ }^{82}$ Valor é definido, a partir de PIAGET, como "um investimento afetivo que nos move ou que nos faz agir". TOGNETTA, Luciene Regina Paulino; VINHA, Telma Pileggi. Valores em crise: o que nos causa indignação? In LA TAILlE, Yves de; DE STEFANO, Maria Suzana; SHIMIZU, Alessandra de Morais (orgs). Crise de valores ou valores em crise? Porto Alegre: Artmed, 2009 p. 15-45; p. 17

${ }^{83}$ TOGNETTA; VINHA, op cit., p. 33. 
Outras respostas foram abrigadas sob as categorias "maus tratos", abrangendo respostas ligadas a "abusos, constrangimento, provocação, agressão verbal, xingamentos, zombarias, insultos, desrespeito" e "violência" ("agressão física") ${ }^{84}$. Essas duas categorias aparecem mais representadas nas respostas de estudantes de escolas públicas (maus tratos $20,83 \%$ x 11,87\% na escola privada; violência 12,5\% x 6,78\%). "Enquanto os alunos de escolas particulares parecem preocupados com a desonestidade, os alunos de escolas públicas referem-se ao que talvez mais sofram: a deseducação como forma de violência e as agressões físicas ou verbais". ${ }^{85}$

Em outra pesquisa ${ }^{86}$, LA TAILLE buscou identificar, com 448 adolescentes do sexo feminino e masculino entre 15 e 18 anos, de escolas públicas e privadas, quais as virtudes mais importantes. Dentre achados não surpreendentes, como o fato de a justiça aparecer entre as três virtudes mais importantes (escolhidas em uma lista de dez, oferecida pelo pesquisador), o autor destaca o fato de a humildade ter aparecido como a virtude mais importante, afirmando a partir disso que, ao contrário do que poderia sugerir, esse resultado indica justamente que vivemos em uma cultura da vaidade, razão pela qual "a humildade apareceria como o antídoto necessário à fogueira de vaidade (...) e às tensões interpessoais decorrentes". ${ }^{87} \mathrm{E}$ a mesma humildade foi citada igualmente como importante em uma pesquisa com adolescentes do sexo masculino internados na então FEBEM (hoje Fundação CASA) $)^{88}$.

Se as pesquisas citadas apontam semelhanças e diferenças entre valores de crianças e adolescentes que vivem no mesmo estado da federação, estado este que é o mais populoso e rico do Brasil, pode-se imaginar o oceano de significativas diferenças que há entre ser criança e adolescente no sertão nordestino, as comunidades ribeirinhas do

\footnotetext{
84 TOGNETTA; VINHA, op cit, p. 24, quadro 1.3.

${ }^{85}$ Idem, ibidem, p. 36.

${ }^{86}$ LA TAILLE, Yves de. As virtudes segundo os jovens. In LA TAILLE, Yves de; DE STEFANO, Maria Suzana; SHIMIZU, Alessandra de Morais (orgs). Crise de valores ou valores em crise? Porto Alegre: Artmed, 2009, p. 46-69.

${ }^{87}$ LA TAILLE, op cit, p. 51-52. O autor não apresenta análise dos resultados por escola pública/privada.

${ }^{88}$ FEBEM era a sigla para Fundação Estadual para o Bem Estar do Menor, instituição de internação de adolescentes em cumprimento de medida socioeducativa de internação imposta como sanção pela prática de ato infracional (ECA, artigos 121 e ss); em 2006 a instituição foi renomeada, passando a se chamar Fundação Centro de Atendimento Socioeducativo ao Adolescente (CASA), tendo passado também por uma reforma institucional (pedagógica, arquitetônica, etc).
} 
Amazonas e na megalópole São Paulo, somente para citar três exemplos extremos da disparidade que caracteriza este país ${ }^{89}$.

Apesar disso, o uso da TIC vem se disseminando de forma cada vez mais rápida em todas as regiões do Brasil, e alcançando as classes sociais mais baixas ${ }^{90}$. Atreladas à realidade social em que vivem, as vivências dessas crianças e adolescentes no uso da tecnologia, serão, em parte, diferentes das vivências dos nativos digitais.

É possível, porém, identificar algumas semelhanças, conforme a pesquisa de LA TAILLE, acima citada, já indica (com a consciência das limitações representadas por toda generalização).

A imersão em uma cultura da imagem ou da vaidade (conforme LA TAILLE, acima) é uma das características que emergem nas pesquisas realizadas com adolescentes e jovens, sendo que a mídia tradicional e as novas TIC ocupam papel determinante dentro dessa cultura. Tanto LA TAILLE ${ }^{91}$ quanto GRINSPUN ${ }^{92}$, em pesquisas sobre valores feitas com jovens em São Paulo e no Rio de Janeiro identificam a centralidade da mídia e da imagem em suas vidas.

LA TAILLE identifica, conforme acima, a humildade como um valor importante para os adolescentes de modo geral, que interpreta como indicativa da presença do valor oposto (a vaidade) na cultura; essa evidência se reforça no exame de outro resultado da mesma pesquisa: quando se pediu aos adolescentes que citassem três pessoas famosas que mereceriam admiração, quase todas as personalidades citadas eram pessoas presentes na mídia, entre elas muitos artistas, tendo sido os primeiros colocados o (já falecido) piloto de Fórmula 1 Ayrton Senna e a apresentadora infantil Xuxa. Enquanto as chamadas “celebridades" foram citadas em peso (51 cantores, 32 esportistas e 21 atores), filósofos e pensadores mereceram meras sete citações, e personagens históricos, cinco.

\footnotetext{
${ }^{89} \mathrm{Em}$ documento já mencionado ( $O$ direito de ser adolescente...), cuja consulta se recomenda, o UNICEF apresenta as vozes de adolescentes dessas diferentes realidades, assim como iniciativas espalhadas pelo país que buscam implementar os seus direitos, garantir sua participação, seu desenvolvimento, sua saúde etc.

${ }^{90}$ Mais adiante, neste mesmo capítulo, são apresentados alguns dados que indicam essa expansão.

${ }^{91}$ LA TAILLE, op cit, p. 54-57.

92 GRINSPUN, Mirian Paura S. Zippin. A razão dos afetos. Revista Viver Mente \& Cérebro, O Olhar Adolescente, Vol. 4 - Espelhos da Sociedade. São Paulo: Duetto, p. 30-37. A pesquisa "Os valores dos jovens no contexto atual" foi realizada pelo grupo de pesquisa "Juventude, Valores e Educação" entre 2004 e 2005; o grupo é coordenado pela autora, que é Professora Titular da Faculdade de Educação da UERJ. Foram entrevistados 1500 jovens (entre 14 e 21 anos) no Rio de Janeiro.
} 
GRINSPUN, por seu turno, afirma, com base nos resultados de sua pesquisa, que "para os jovens, a cultura midiática ocupa lugar determinante. $\mathrm{O}$ universo da imagem é o melhor meio de entender o mundo, e eles sofrem grande influência dos meios de comunicação de massa. As tecnologias de consumo e mercado transformam valores morais em categorias econômicas e os levam a desejar adquirir coisas de forma imediatista" $" 93$.

No mesmo sentido, em artigo a respeito da relação entre juventude e mídia, CANHONI ${ }^{94}$ identifica a cultura da imagem como importante na construção da subjetividade de adolescentes; nesta cultura, o que importa é a "consagração do "eu”, com ênfase no consumo e na estética corporal, que se torna objeto permanente de admiração e reconhecimento à medida que for capaz de alcançar os ideais capturados na fugacidade das imagens que privilegiam a exterioridade." 95

A cultura da vaidade, porém, não é exclusiva dos adolescentes - estamos, também os adultos, nela imersos, "até as orelhas". E a comunicação é um fator estimulante desta cultura. LA TAILLE, baseando-se em BAUMAN, problematiza e complementa a análise de CASTELLS, acima apresentada. Estamos, diz o professor da USP, “em época de muita comunicação, sim, mas de pouca troca" ${ }^{\prime 96}$. Imperativo dos tempos atuais, a comunicação, representada, por exemplo, pelo celular, é apresentada como bem necessário para uma vida boa, já que proporciona a comunicação, une as famílias, os amigos; nas propagandas, o celular é associando à qualidade de vida e a sentimentos bons como o amor, a amizade, a liberdade.

A comunicação adquire, então, um lugar tão central nas vidas das pessoas que aquele que se sente excluído desse mundo, está excluído da sociedade e de todas as oportunidades maravilhosas que o celular (ou a internet) pode oferecer. E estar conectado não significa estar mais próximo, ou trocar mais: o autor menciona estudo feito com jovens usuários de bate-papos na internet que indica que a atividade é mais relacionada com divertimento do que com a vivência de diálogos edificantes. O autor, como CASTELLS, identifica a partir da mudança na comunicação uma mudança na

\footnotetext{
${ }^{93}$ GRINSPUNT, op cit., p. 34.

${ }_{95}^{94}$ Psicanalista e mestre em psicologia clínica pela PUC-SP.

${ }^{95}$ CANHONI, Vera. Uma questão de imagem. Revista Viver Mente \& Cérebro, O Olhar Adolescente, Vol. 4 - Espelhos da Sociedade. São Paulo: Duetto, p.39-47; p, 39.

${ }^{96}$ LA TAILLE, Yves de. Formação Ética: do tédio ao respeito de si. Porto Alegre: Artmed, 2009; p. 51.
} 
sociabilidade, um "novo estilo de convivência social" que exclui e suspeita do silêncio, dos tímidos, dos solitários. Para pertencer é preciso se comunicar.

À necessidade de se comunicar se junta a cultura do prazer efêmero, instantâneo e que precisa ser ao tempo todo comunicado e exibido. A cultura da imagem é potencializada pelos recursos oferecidos pela internet, em especial pelo conceito da web 2.0, acima descrita. As redes sociais propiciam caminhos alternativos para a, na maior parte das vezes, efêmera fama virtual. As fotos e postagens, que devem ser sempre positivas (mostrando o usuário da rede se divertindo, ou dizendo coisas engraçadas ou inteligentes), projetam uma autoimagem, uma narrativa autocentrada e narcísica, exaltadora de um eu ideal, embora dependente da aprovação do outro. "Centrado no próprio umbigo, o sujeito não se interessa pelo outro, a não ser como objeto capaz de incrementar e elevar a autoimagem"97.

\subsubsection{Infâncias e adolescências na sociedade em rede: cultura e práticas sociais on- line.}

Se toda a sociedade parece estar mergulhada na cultura da vaidade, da comunicação instantânea e das conexões efêmeras, a necessidade de ser socialmente aceito, de estar conectado e de ser visto e reconhecido, parece ganhar mais força e evidência especialmente na adolescência, já que este é um momento apontado pelos estudiosos como de busca de identidade ${ }^{98}$.

Adolescentes parecem gostar tanto de redes sociais pois, por meio dos seus perfis, construídos para ser vistos por seus pares, é possível construir a sua imagem, mostrando para os demais os aspectos da personalidade que serão avaliados como "legais". O número de amigos que se tem e, mais ainda, quem faz parte de sua rede de amigos, e qual a sua "audiência" são importantes medidas para saber se você é popular na rede e passam a fazer parte desse processo de construção identitária ${ }^{99}$.

\footnotetext{
${ }^{97}$ CANHONI, op cit, p. 46.

${ }^{98}$ Cf Capítulo 4.

${ }^{99}$ BOYD, Danah. Why Youth love Social Network Sites: The Role of Networked Publics in Teenage Social Life. In Youth, Identity, and Digital Media. Edited by David Buckingham. The John D. and Catherine T.
} 
$\mathrm{Na}$ internet, a popularidade representa maior número de amigos listados no Facebook ${ }^{100}$, mais postagens "curtidas" e comentadas, mais seguidores no Twitter ${ }^{101}$, mais visitantes no $b \log$, mais visualizações do vídeo no YouTube $e^{102}$. A lógica das redes sociais e isso vale também para os adultos - não permite ao usuário ser infeliz; não há espaço para "perdedores" ou deprimidos.

Persistência, "buscabilidade", replicabilidade e audiências invisíveis são quatro propriedades das redes sociais on-line (mediadas) com as quais usuários têm de aprender a lidar para serem capazes de navegar nos mares da nova sociabilidade sem correr o risco de perder o controle do barco ${ }^{103}$ :

- Persistência: todas as comunicações realizadas por meio da rede podem ser gravadas para a posteridade;

- "Buscabilidade"104: Como a maior parte das expressões nas redes sociais é feita por meio do texto, ferramentas de busca ajudam as pessoas a, facilmente, encontrar outras pessoas que compartilhem da mesma forma de pensar: basta inserir as palavras-chave certas;

- Replicabilidade: Podem-se copiar expressões de um lugar para outro, tirando o original do contexto de modo que pode não ser possível saber qual o original e qual a cópia;

- Audiências invisíveis: Em espaços não mediados, normalmente podemos detectar visualmente quem é a nossa "audiência"; no mundo on-line, é virtualmente impossível saber quem pode estar "ouvindo", característica que se complica pelo fato de que o discurso original pode ser ouvido em um momento e lugar diferentes daqueles onde foi originalmente proferido.

As características acima são, muitas vezes, negligenciadas pelos adolescentes. A falta de experiência pode fazer com que adolescentes se exponham mais do que o

MacArthur Foundation Series on Digital Media and Learning. Cambridge, MA: The MIT Press, 2008. 119142. doi: 10.1162/dmal.9780262524834.119.

${ }^{100}$ Cf. Glossário, anexo.

${ }^{101}$ Cf. Glossário.

${ }^{102}$ Cf. Glossário.

${ }^{103}$ BOYD, op cit, p. 126.

${ }^{104}$ Tradução literal, feita pela autora, da expressão "Searchability", termo utilizado no artigo original, em inglês. 
apropriado, na busca da construção de sua identidade. O maior risco, alerta ARATANGY, "é que a rede confere um grande poder de divulgação, ao mesmo tempo que isenta o usuário de qualquer responsabilidade pelo material que divulga. (...) Numa postura irreal e quase ingênua, muitos jovens se comportam como se a vida virtual estivesse totalmente separada da realidade" ${ }^{105}$, quando, na verdade os mundos real e virtual estão intimamente conectados.

O poder de exposição da rede se torna facilmente verificável ao examinar a versão virtual (cyberbullying) das práticas de violência na escola que passaram a ser conhecidas como bullying ${ }^{106}$. O bullying "tradicional" compreende "todas as atitudes agressivas, intencionais e repetidas, que ocorrem sem motivação evidente, adotadas por um estudante ou uma pessoa contra seus pares, causando dor e angústia, e ocorrendo dentro de uma relação desigual de poder, causando a intimidação da vítima. (...) Estes comportamentos podem ter ações diretas e físicas (bater, chutar), verbais (insultos, atitudes preconceituosas) e sexuais (voyeurismo, gozações, esbarrões com atitudes sexuais); ou ações indiretas ou emocionais (pressões para a pessoa ser excluída, disseminação de histórias indecentes etc.)" ${ }^{107}$.

São características do bullying, ainda segundo a autora:- comportamento danoso deliberado; repetitivo durante um período de tempo; dificuldade de defesa para o agredido; dificuldade do agressor em aprender novos comportamentos socialmente aceitos; sensação ou situação de poder "impróprio" do agressor, que repercute na vítima.

As práticas humilhantes entre pares, que vão desde a violência verbal até a violência física, sempre existiram, mas foi somente a partir da década de 1990 que se passou a dar atenção ao fenômeno no Brasil. Percebeu-se que o bullying pode ter efeitos psicológicos negativos tão graves a ponto de levar, nos casos mais extremos, ao suicídio ou à violência contra colegas e professores; a maioria dos adolescentes que sofrem este tipo de reiterada violência, contudo, pode apresentar problemas menos graves, mas não

\footnotetext{
105 ARATANGY, Lidia Rosenberg. Adolescentes Na Era Digital. São Paulo: Benvirá, 2011; p. 39.

${ }^{106}$ A palavra não tem tradução concisa para o português que exprima o significado que carrega em inglês. A tradução literal seria "intimidação". O termo em inglês acabou sendo adotado no Brasil, já que ele expressa de forma concisa uma série de atitudes mais ou menos agressivas praticadas, especialmente, na escola e entre adolescentes.

107 WILlIAMS, Lúcia Cavalcanti de Albuquerque. (Org.); PADOVANI, Ricardo da Costa (Org.); ARAUJO, Eliane A C (Org.); STELKO-PEREIRA, A. C. (Org.); ORMEÑO, Gabriela Isabel Reyes (Org.); EINSTEIN, E. (Org.). Fortalecendo a Rede de Proteção da Criança e do adolescente. São Carlos: Pedro e João Editores, 2010. 68 p.; p.10
} 
menos importantes, como depressão, baixa autoestima e dificuldades de relacionamento social, e que podem ter repercussão até a vida adulta ${ }^{108}$.

Se é correto afirmar que o desrespeito aos valores e a violência da prática do bullying têm o mesmo princípio de outros tempos, também é verdade que "a internet deu ao bullying uma violência e um alcance infinitamente maiores do que as inscrições nas portas do banheiro da escola" ${ }^{109}$.

O cyberbullying - modalidade de bullying praticada on-line - traz consequências exponenciais que ultrapassam espaços físicos. Há fatores diferentes que se apresentam no cyberbullying, como a quantidade do público (audiências invisíveis) e de tempo em que fica exposta a vítima (persistência e replicabilidade: a informação on-line se multiplica rapidamente e, por isso, tende a perdurar no tempo -, aumentando a revitimização) e o anonimato, entre outras questões; esses fatores podem aumentar significativamente o impacto dos efeitos negativos nas vítimas.

Nos casos limites do bullying escolar das gerações anteriores, trocar de escola representava uma solução para crianças e adolescentes que se sentissem hostilizados no ambiente escolar. O cyberbullying acrescenta uma nova "camada" ao conflito, que passa a atingir um público maior e que acompanha o adolescente inclusive dentro do ambiente familiar, onde ele, anteriormente, se encontrava protegido. As modalidades de violência virtual (xingamentos, humilhações, páginas falsas, divulgação de fotografias e de montagens etc) são somadas às vivências de violência física e/ou psíquica que ocorrem no mundo real.

Desnecessário dizer que quanto mais "conectados" os adolescentes envolvidos nas práticas do bullying, maior a chance de ele se desenvolver para a sua modalidade virtual e maior o impacto que isso pode ter na vida de quem sofre as violências. É bom lembrar que os brasileiros estão entre os que mais usam redes sociais como Facebook, Orkut,

\footnotetext{
${ }^{108}$ Um estudo realizado nos EUA apresenta os seguintes dados: 45\% das vítimas de cyberbullying relataram sentimento de depressão; $38 \%$ se sentiram envergonhados e $28 \%$ ficaram preocupados em como frequentar a escola. Os autores relataram, ainda, que mais de um quarto $(26 \%)$ dos pesquisados tiveram pensamentos suicidas". Iowa State researchers publish national study on cyberbullying of LGBT and allied youths (http://www.news.iastate.edu/news/2010/mar/cyberbullying), apud THE ONLINE SAFETY AND TECHNOLOGY WORKING GROUP. YOUTH Safety on a Living Internet. Report. 2010. Disponível em: http://www.ntia.doc.gov/reports/2010/OSTWG_Final_Report_060410.pdf; p. 12-13.

${ }^{109}$ ARATANGY, op cit, p. 13.
} 
Twitter e similares no mundo ${ }^{110}$, e o uso de algumas dessas redes, como o Orkut, é dominado, especialmente, por adolescentes ${ }^{111}$.

Como se vê, a TIC oferece a crianças e, principalmente, adolescentes, novos espaços (e formas) de sociabilidade, que se entremeiam com os tradicionais espaços e práticas do mundo off-line. Ao mesmo tempo em que esses novos espaços e práticas acrescentam mais uma "camada" de sociabilidade e interação, o que pode ser positivo, suas características os tornam, também, espaços com potencial de ampliação dos conflitos que aconteceriam naturalmente na "vida real".

E quando a sociabilidade e a interação envolvem aspectos do desenvolvimento como a descoberta da sexualidade, é preciso orientar os adolescentes para que possam exercitá-la nesses novos espaços com ética, respeito (incluindo o autorrespeito) e com a segurança possível dentro do contexto naturalmente inseguro das transformações da adolescência que é vivida numa sociedade também em (veloz) transformação.

\subsubsection{Infâncias e adolescências na sociedade em rede: sexualidade e TIC}

Se a tecnologia está assim tão presente nas vidas de crianças e adolescentes, não é de espantar que recorram a ela para se informar a respeito da sexualidade. Especialmente quando tomamos em consideração que o sexo e a sexualidade ainda são, apesar de todas as transformações sociais, considerados assuntos-tabu, apesar de, ao mesmo tempo, serem fator central na vida humana.

\footnotetext{
${ }^{110}$ Diversas pesquisas já foram divulgadas informando que o Brasil é líder mundial em uso de redes sociais no mundo. Cf, por exemplo, reportagem do site de tecnologia IDG Now! ("Internauta brasileiro lidera uso de rede social em todo o mundo", publicada em 15 de junho de 2010 às 19h08; Atualizada em 16 de junho de 2010 às 00h52) que se referia a dados de 2010 (disponível em http://idgnow.uol.com.br/internet/2010/06/15/internauta-brasileiro-lidera-uso-de-rede-social-em-todo-omundo/, consulta em 07/02/2012); outro relatório, publicado em 2011 pela empresa de pesquisa de mercado TNS e contendo dados referentes a este mesmo ano, indicava que os brasileiros têm mais amigos em redes sociais do que a média mundial (em média 231 amigos, enquanto que a média mundial é 120 e a média na América Latina é 176 (“GEMS - Insight from emerging markets - March 2011", disponível em http://www.tnsglobal.com/ assets/files/TNS_GEMS March2011.pdf; consulta em 07/02/2012).

${ }^{111} \mathrm{O}$ gosto pelas redes sociais não é exclusivo de adolescentes brasileiros. Artigo do pesquisador da Universidade de Berkeley, EUA, intitulado "Por que os jovens amam as redes sociais" cita a seguinte frase de um adolescente sobre a rede social MySpace (à época da pesquisa, extremamente popular): "Se você não está no MySpace, você não existe". BOYD, op cit.
} 
Apesar de se concentrar em revisão de literatura de pesquisas realizadas nos EUA, alguns aspectos levantados na obra "Crianças, Adolescentes e a Mídia" a respeito da sexualidade merecem menção, em especial pelo fato de serem facilmente constatadas na realidade brasileira a partir de observações "leigas".

Segundo os autores, a televisão e as novas mídias parecem ser a principal fonte de educação sexual nos Estados Unidos ${ }^{112}$, já que os pais, a escola e os amigos parecem ter capacidade limitada de influenciar na educação sexual.

Os pais raramente discutem a atividade sexual ou controle de natalidade com seus filhos, embora apoiem a educação sexual na escola. A educação social na escola, contudo, é incompleta, focada na abstinência sexual e, em alguns casos, tardia.

Adolescentes buscam também ajuda junto aos seus pares, mas as respostas podem ser "incompletas, equivocadas, distorcidas e transmitidas através de piadas ou contando vantagens" ${ }^{113}$. Além disso, há indícios de que a mídia influencia a percepção dos adolescentes a respeito do sexo: adolescentes que são consumidores ávidos de mídia parecem superestimar a quantidade de seus amigos e pares que já são sexualmente ativos, além de sentir mais pressão da mídia para fazer sexo.

Quando perguntados a respeito do papel da mídia na obtenção das informações sobre sexo, os adolescentes indicam que sim, a mídia é importante, mas (um fenômeno conhecido como "terceira pessoa") não admitiam a influência sobre o próprio comportamento (todos são influenciados pela mídia, exceto a própria pessoa).

Apesar disso, e apesar do fato de que sexo (especialmente a mulher enquanto objeto sexual) pode ser, e é (como é conhecimento comum) utilizado para "vender" virtualmente qualquer produto, as campanhas educativas $\mathrm{e}$ as propagandas de preservativos e de outras formas de controle da contracepção e de doenças sexualmente transmissíveis (DSTs) são quase invisíveis, sob o argumento de que poderiam suscitar polêmica $^{114}$.

\footnotetext{
${ }^{112}$ STRASBURGUER V.C.; WILSON, B. J.; JORDAN, A.B. (orgs). Op cit, p.200.

${ }^{113}$ Idem, ibidem, p, 214.

${ }^{114}$ Nunca é demais lembrar que a sociedade estadunidense, apesar de ser uma das maiores consumidoras de filmes pornográficos do mundo e de possuir uma indústria desse gênero que movimenta milhares de dólares por ano, se chocou, em 1991, com a foto da atriz Demi Moore grávida e nua na capa da revista Vanity Fair.
} 
A internet também aparece, hoje, como uma fonte importante de educação sexual para adolescentes. É tão fácil buscar e obter informações a respeito de contracepção e DSTs de modo privado, anônimo e rápido, quanto ver vídeos de sexo e obter orientações a respeito de como se comportar sexualmente.

Ao mesmo tempo, as redes sociais e os blogs aparecem como um novo locus para a exploração da sexualidade e identidade. É comum, especialmente entre as meninas, a publicação de fotos em poses "sensuais" em blogs ou mesmo em suas páginas das redes sociais.

A partir da disseminação do celular multifuncional (smartphone), capaz de tirar fotos e enviá-las instantaneamente, seja por meio de mensagem multimídia (MMS) ${ }^{115}$ ou por meio de programas que publicam a foto diretamente em redes sociais, uma nova prática surgiu entre adolescentes: o sexting.

Sexting, neologismo originado da união de duas palavras em inglês: "sex" (sexo) com "texting" (envio de mensagens) ${ }^{116}$, é a "prática de enviar ou publicar imagens e textos sexualmente sugestivos, incluindo fotografias nuas ou seminuas, por meio de celulares ou da internet" ${ }^{\prime 17}$. A prática do sexting pode acontecer por meio de envio de MMS, em salas de bate-papo on-line, em redes sociais, ou usando comunicadores instantâneos (messengers). Dentre os estudantes entrevistados pela SaferNet, 12,1\% admitiram já ter postado fotos íntimas na rede ${ }^{118}$.

O envio de fotos entre namorados, ou até mesmo a filmagem de práticas sexuais entre adolescentes não representa, a princípio, problema algum, se as imagens ficarem restritas à intimidade dos adolescentes. O que pode gerar repercussões drásticas é o compartilhamento das imagens ou vídeos com outros adolescentes. Os casos mais comuns relatados são os de adolescentes do sexo feminino que enviam fotos sensuais para o

\footnotetext{
${ }^{115}$ MMS - mensagem de texto com anexo, que pode ser uma foto, um vídeo ou música. Cf. Glossário.

${ }^{116}$ Do inglês "to text" (também um neologismo), verbo nascido na era da tecnologia para designar o ato de enviar mensagens de texto.

${ }^{117}$ LEVICK, Marsha; MOON, Kristina. Prosecuting Sexting as Child Pornography, 44 Val. U. L. Rev. 1035 (2010). Disponível em http://scholar.valpo.edu/vulr/vol44/iss4/2, consulta em 07/02/2012.

${ }^{118}$ SaferNet Brasil. Relatório da Pesquisa Online - Brasil: "Hábitos de Navegação na Internet: será que nossos alunos e educadores navegam com segurança na Internet?". Safernet, 2009. Disponível em http://www.safernet.org.br/site/sites/default/files/RELATORIO\%20PESQUISA\%20EDUCA\%20BR\%2020 09.pdf. Download em 23/12/2010; p.12-14.
} 
"ficante" ou namorado, que então compartilha a foto com os seus amigos ou colegas, ou a coloca na internet.

Um exemplo ilustrativo: uma estudante havia mantido relações sexuais com um adolescente com quem se relacionava de forma casual (um "ficante") e o menino, sem a sua permissão, gravou as imagens e publicou na internet. A adolescente passou a ser perseguida na escola e no bairro, pessoas jogaram pedras e picharam o muro de sua casa com palavras ofensivas. A violência chegou a um ponto em que a adolescente não podia mais sair de casa. Já o menino não sofreu nenhuma represália moral ${ }^{119}$.

As meninas, por uma série de razões, parecem ser particularmente vulneráveis ao sexting. Na pesquisa "Because I Am A Girl" (Por que sou uma menina) ${ }^{120}$, as respondentes dos grupos focais realizados com adolescentes estudantes de escolas públicas e particulares de Santo André e São Paulo relataram:

"Minha amiga confiou em um amigo e mostrou a ele uma foto dela nua, e então ele distribuiu a foto para o clube inteiro." (Menina, 12 anos)

"As meninas ligam a câmera e mostram partes do corpo que não deveriam ser mostradas." (Menina, 13 anos") ${ }^{121}$

A pesquisa detectou, em consonância com outros estudos, que a baixa autoestima, aliada a uma errônea percepção de que serão valorizadas por mostrarem o corpo (mensagem que a mídia repete incessantemente), são alguns dos fatores que levam essas meninas a expor-se na internet. O resultado é desastroso: os meninos, apesar de estimularem as meninas a se exporem cada vez mais, consideram-nas "vadias", extrapolando esta concepção e uma correspondente agressividade para as meninas em geral com quem se relacionam (por exemplo, na escola).

\footnotetext{
${ }^{119} \mathrm{O}$ caso foi-me relatado por uma educadora da organização não governamental "Associação Obra do Berço", que atende crianças e adolescentes em horário complementar à escola, durante uma reunião do Programa CPP. Fato similar aconteceu no município de São Carlos/SP, conforme relato que me foi feito, em março de 2011, por profissionais que trabalham com crianças e adolescentes.

120 A pesquisa compreendeu avaliações quantitativas e qualitativas (grupos focais); o resultado está consubstanciado no capítulo "Adolescentes Brasileiras e sua Realidade no Mundo Virtual” In PLAN INTERNATIONAL, op cit. O relatório integral só está disponível em inglês, porém há versões em português do sumário executivo e do capítulo mencionado disponíveis em http://www.plan.org.br/publicacoes/index.html.

${ }^{121}$ Idem, ibidem, p. 131.
} 
O sexting pode ser a porta de entrada para o cyberbullying, já mencionado acima, e para o despertar do interesse de adultos com intenção de aliciar crianças e adolescentes para a prática de abuso ou exploração sexual (grooming/aliciamento e abuso sexual online $)^{122}$. A foto publicada na internet pode dar ensejo, ainda, à manipulação de imagens para a criação de pornografia infanto-juvenil, que serão posteriormente disponibilizadas on-line.

O cyberbullying pode envolver a criação de páginas e perfis falsos da vítima em redes sociais com imagens manipuladas ou páginas criadas especialmente para ofender a vítima. A prática não tem, necessariamente, ligação com a sexualidade, mas pode ter conteúdo que ofenda este aspecto da vida dos adolescentes.

Estas práticas trazem um problema adicional à questão da prevenção, já que são praticados pelas próprias crianças e adolescentes. Se não é possível considerá-las como violência sexual stricto sensu ${ }^{123}$, pode-se afirmar, por outro lado, que podem ser carregadas de violência psicológica relevante, com resultados bastante preocupantes, como os já relatados anteriormente quando se mencionou o cyberbullying.

Até recentemente, não havia legislação penal que tipificasse especificamente condutas como o sexting, que é uma prática que só passou a existir com o desenvolvimento e difusão da TIC (o cyberbullying, normalmente, ocorre como desdobramento de outras práticas vexatórias e humilhantes praticadas também off-line). Recentes mudanças no ECA, por meio da Lei $\mathrm{n}^{\circ} 11.829$, de 2008, porém, abrem a porta para a persecução, no âmbito do Direito Penal Juvenil, de adolescentes que pratiquem a conduta.

Os artigos $240^{124}, 241-\mathrm{A}^{125}$ e $241-\mathrm{B}^{126}$, a partir da mencionada lei, tipificam condutas que, caso não se atente para a finalidade original da lei, que era coibir as

\footnotetext{
${ }^{122}$ A respeito dessas condutas, cf. Capítulo 2.

${ }^{123}$ Confira Capítulo 2 para uma discussão a respeito da definição de violência sexual mediada pela TIC que está sendo adotada neste trabalho.

${ }^{124}$ Transcrevo os artigos parcialmente, para os fins ora discutidos (possibilidade de responsabilização de adolescentes no âmbito do Direito Penal Juvenil): “Art. 240. Produzir, reproduzir, dirigir, fotografar, filmar ou registrar, por qualquer meio, cena de sexo explícito ou pornográfica, envolvendo criança ou adolescente: Pena - reclusão, de 4 (quatro) a 8 (oito) anos, e multa.

$\S 1^{\mathrm{o}}$ Incorre nas mesmas penas quem agencia, facilita, recruta, coage, ou de qualquer modo intermedeia a participação de criança ou adolescente nas cenas referidas no caput deste artigo, ou ainda quem com esses contracena."
} 
condutas genericamente denominadas de "pornografia infantil", podem perfeitamente ser consideradas para a punição do sexting ou de algumas práticas do cyberbullying.

Esta advertência é necessária porque, nos EUA, já há relatos de persecução penal contra adolescentes que praticaram sexting, sendo que as condutas têm sido enquadradas nos tipos penais de pornografia infantil ${ }^{127}$ (o que corresponde, exatamente, à hipótese que se levanta ao mencionar os novos tipos penais do ECA).

Como a conduta dos adolescentes enquadra-se na descrição da "posse ou distribuição de pornografia infantil", sendo a pornografia infantil é definida como a "representação da imagem [depiction] de um menor nu", promotores de justiça estão enquadrando adolescentes que praticam sexting nos tipos penais, argumentando que a persecução penal ajuda a inibir esse tipo de comportamento de risco.

Segundo LEVICK e MOON, isso pode acarretar a inclusão de adolescentes em cadastros de ofensores sexuais (sex offenders) ${ }^{128}$, além de todos os demais prejuízos decorrentes da criminalização desnecessária de adolescentes por práticas que deveriam ser discutidas e enfrentadas pelo sistema de controle social informal (família e escola), já que inseridas no processo de desenvolvimento dos adolescentes.

Para evitar a persecução penal do sexting como pornografia infantil, há estados americanos que estão propondo a criação de novos tipos penais de menor potencial ofensivo (misdemeanor), enquanto que outras jurisdições estão desenvolvendo programas de educação e prevenção nas escolas.

\footnotetext{
125 "Art. 241-A. Oferecer, trocar, disponibilizar, transmitir, distribuir, publicar ou divulgar por qualquer meio, inclusive por meio de sistema de informática ou telemático, fotografia, vídeo ou outro registro que contenha cena de sexo explícito ou pornográfica envolvendo criança ou adolescente:

Pena - reclusão, de 3 (três) a 6 (seis) anos, e multa."

126 "Art. 241-B. Adquirir, possuir ou armazenar, por qualquer meio, fotografia, vídeo ou outra forma de registro que contenha cena de sexo explícito ou pornográfica envolvendo criança ou adolescente:

Pena - reclusão, de 1 (um) a 4 (quatro) anos, e multa.

$\S 1$ o A pena é diminuída de 1 (um) a $2 / 3$ (dois terços) se de pequena quantidade o material a que se refere o caput deste artigo."

${ }^{127}$ Segundo LEVICK e MOON, já houve processos por sexting nos estados do Alabama, Florida, Indiana, Iowa, New Jersey, Ohio, Oregon, New York, Pennsylvania, Texas, Virginia, Washington, and Wisconsin. LEVICK e MOON, op cit, p.1037, nota de rodapé 4.

${ }^{128}$ Nos EUA, esses cadastros têm extrema importância; uma pessoa condenada por violência sexual contra criança ou adolescente, por exemplo, tem que avisar o Sistema de Justiça ao mudar de cidade, mesmo que já tenha cumprido integralmente sua pena. $\mathrm{O}$ sistema promove uma estigmatização e controle tais que torna a convivência social extremamente difícil para um ex-condenado por crime sexual contra criança, já que ele sempre estará na lista dos "sex offenders".
} 
Para as autoras, os tipos penais de pornografia infantil na legislação estadunidense são absolutamente inadequados para a situação do sexting praticado por adolescentes, pois as penas cominadas, classificadas pelas autoras como draconianas, são as mais longas do sistema de justiça criminal daquele país; além disso, a descrição legal de pornografia infantil legal não deve ser tomada ao pé da letra, devendo-se verificar a mens legis e a intenção do autor, além do exame das imagens em si, quando se indaga a respeito da qualificação de imagens de sexting como pornografia infantil.

De fato, há inúmeras objeções que podem ser feitas ao risco de transformar práticas juvenis como sexting e cyberbullying em crimes de pornografia infantil. Haveria evidente violação a princípios basilares do direito penal como a legalidade (especialmente taxatividade), a intervenção mínima, a proporcionalidade, além dos próprios princípios do direito da criança e do adolescente, em especial o da condição peculiar de pessoa em desenvolvimento ${ }^{129}$.

Esta é mais uma razão para o investimento em programas de prevenção. Nestes casos, porém, não se trata de exclusiva prevenção vitimal, não só porque a relação vítimaofensor, em alguns casos, não é clara nas situações envolvendo adolescentes (e, eventualmente, crianças, em especial no caso do bullying), mas também porque, nesses casos, é necessário promover ações de prevenção junto a todos os adolescentes, inclusive e principalmente com relação àqueles que seriam os autores da violência psíquica.

Os casos de cyberbullying e sexting são alguns exemplos de novos conflitos que podem ser desencadeados pelo uso da TIC sem orientação e supervisão adequada. Riscos mais graves, porém, estão presentes nas vidas de crianças e adolescentes conectados na sociedade em rede. Antes de nos debruçarmos especificamente sobre eles, é necessário dar voz a crianças e adolescentes para que possam contar um pouco mais a respeito do papel que a TIC ocupa em suas vidas, como é seu cotidiano utilizando esta tecnologia e quem está presente nestes momentos para ajudá-los e orientá-los.

\footnotetext{
${ }^{129}$ Cf, a respeito, Capítulo 4.
} 


\subsection{Crianças, adolescentes e o uso da TIC no Brasil: contextualização quantitativa e qualitativa}

Uma das principais funções do Comitê Gestor de Internet do Brasil é a de elaborar pesquisas sobre hábitos de uso de Tecnologias da Comunicação e Informação (TIC) no Brasil 130. A mais recente publicação é a "Pesquisa sobre o uso das tecnologias de informação e comunicação no Brasil: TIC Domicílios e TIC Empresas 2010” (Pesquisa TIC Domicílios).

A iniciativa está em consonância com as preocupações de "organizações internacionais como Organização das Nações Unidas (ONU), Organização para a Cooperação e Desenvolvimento Econômico (OCDE), Banco Mundial, entre outras [que] trabalham de forma colaborativa na definição de metodologias, indicadores e métricas que sejam capazes de medir o acesso, o uso e a apropriação das novas tecnologias, base para o desenvolvimento da sociedade da informação" ${ }^{\text {131 }}$. A edição 2010 da TIC Domicílios é a sexta e até o momento mais recente pesquisa sobre o uso das tecnologias da informação ${ }^{132}$ e comunicação no Brasil e procura mapear tanto áreas urbanas como as rurais. Para efeito desta pesquisa, são destacados os dados contidos nos capítulos que tratam dos hábitos de navegação de crianças e adolescentes. O CGI também disponibiliza os resultados da Pesquisa TIC Crianças 2009 e $2010^{133}$.

\footnotetext{
130 "Entre suas diversas atribuições e responsabilidades, o CGI.br fomenta a coleta, a organização e a disseminação de informações, análises, indicadores e estatísticas sobre as tecnologias de informação e comunicação (TIC) no Brasil, em particular a Internet. Por meio do seu Centro de Estudos sobre as Tecnologias da Informação e da Comunicação (Cetic.br), são conduzidos diversos projetos de pesquisa especializados nesse tema, visando à medição e ao acompanhamento da expansão das TIC no país." Pesquisa sobre o uso das tecnologias de informação e comunicação no Brasil : TIC Domicílios e TIC Empresas 2010 = Survey on the use of information and communication technologies in Brazil : ICT Households and ICT Enterprises 2010 / [coordenação executiva e editorial/ executive and editorial coordination, Alexandre F. Barbosa ; tradução/ translation Karen Brito Sexton]. -- São Paulo : Comitê Gestor da Internet no Brasil, 2011; p. 29. Disponível em http://cetic.br/pesquisas-cetic.htm, download em 04/10/2011.

${ }^{131}$ Pesquisa TIC Domicílios, p. 31.

132 "Foram consideradas as seguintes tecnologias de informação e comunicação como parte da infraestrutura de TIC nos domicílios: televisão, rádio, telefone celular, telefone fixo, computador de mesa, antena parabólica, aparelho de jogo (videogame), TV por assinatura e computador portátil”. Pesquisa TIC Domicílios, p.139.

${ }^{133}$ Pesquisa sobre o uso das tecnologias da informação e da comunicação no Brasil : TIC Crianças $2009=$ Survey on the use of information and communication technologies in Brazil : ICT Kids 2009 / [coordenação executiva e editorial/executive and editorial coordination, Alexandre F. Barbosa ; tradução/translation Karen Brito]. -- São Paulo : Comitê Gestor da Internet no Brasil, 2010. Disponível em http://cetic.br/pesquisascetic.htm, download em 04/10/2011.; Pesquisa sobre o uso de tecnologias de informação e comunicação no
} 
Outros resultados relevantes são encontrados na pesquisa realizada pela SaferNet Brasil (Safernet), ONG cuja missão declarada é a de defender os direitos humanos na internet e auxiliar governos na elaboração de políticas públicas relacionadas. A Pesquisa SaferNet 2009 foi aplicada em oito estados com o apoio do Ministério Público Federal e dos respectivos MPs estaduais e enfatiza os "hábitos e vulnerabilidades de crianças e adolescentes quando estão on-line." 134

A importância de estudos dessa natureza vai ao encontro das possibilidades e desafios da internet 2.0, conceito formulado para dar conta das características de uma internet mais participativa, no qual os usuários tornam-se também agentes ativos com seus blogs, perfis em redes sociais, compartilhamento de vídeos etc.

A pesquisa TIC Domicílios destaca-se pela confiabilidade; por obedecer a critérios e procedimentos rigorosos; pela amplitude do universo de amostragem (a amostra principal contou com 23.107 domicílios, cobrindo todo o território nacional, inclusive as áreas rurais) $)^{135}$; por darem um destaque especial à relação de crianças e adolescentes com a internet, e por seu diálogo com pesquisas internacionais similares, como a EU Kids Online, iniciativa do "Programa por uma Internet mais segura" da Comissão Europeia.

A pesquisa TIC Domicílios abrange usos da TIC por pessoas a partir de 10 anos, sendo que, da amostra entrevistada, 19\% dos entrevistados têm entre 10 e 15 anos; 17\% estão na faixa de 16 a $24 \operatorname{anos}^{136}$.

As pesquisas TIC Crianças e SaferNet valeram-se de estratégias metodológicas distintas, porém complementares, para a coleta, tabulação, mensuração e consolidação dos

Brasil : TIC Crianças 2010 - ICT Kids 2010 : Survey on the use of information and communication technologies in Brazil / [coordenação executiva e editorial/executive and editorial coordination Alexandre F. ; tradução para o inglês / translation into English Karen Brito-Sexton]. - São Paulo : Comitê Gestor da Internet no Brasil, 2012. Disponível em http://www.cetic.br/tic/criancas/2010/index.htm, download em $16 / 01 / 2012$.

${ }^{134}$ SaferNet Brasil. Relatório da pesquisa online - Brasil: Hábitos de Navegação na Internet: será que nossos alunos e educadores navegam com segurança na Internet? 2009. Disponível em http://www.safernet.org.br/site/sites/default/files/RELATORIO\%20ALUNOS\%20NACIONAL\%202009.pd f, p. 4

${ }^{135}$ Na pesquisa TIC Domicílios 2010, “das 23.107 entrevistas da amostra principal, 8.432 correspondiam a usuários de Internet, ou seja, pessoas que informaram ter acessado a rede nos últimos três meses. Adicionouse a esse grupo a oversample de usuários de Internet, com 1.500 novas entrevistas. A soma das duas amostras totalizou 9.932 respondentes, todos usuários da rede, para os quais foram aplicadas as questões específicas sobre o uso da Internet" p. 125.

${ }^{136}$ Pesquisa TIC Domicílios 2010, p. 131. 
resultados. A TIC Crianças 2009 fez pesquisas de campo em domicílios e concentrou-se na faixa etária dos 5 aos 9 anos, tendo entrevistado 2.502 indivíduos presencialmente, em suas residências, realizadas com a presença dos pais e/ou responsáveis ao lado das crianças, cobrindo todo o território nacional, inclusive áreas rurais ${ }^{137}$.

Apesar de não explicitar com o mesmo rigor que a pesquisa do CGI os procedimentos metodológicos utilizados, e de ter utilizado amostra mais restrita, a pesquisa da Safernet também traz dados importantes e mais específicos a respeito de alguns usos da TIC por crianças e adolescentes, sendo suficiente para complementar a pesquisa do CGI para os fins de caracterização aqui pretendidos.

A metodologia utilizada nesta pesquisa foi o preenchimento de formulário on-line respondido por 2525 alunos e 966 educadores das redes pública e privada dos ensinos fundamental e médio. A idade dos alunos consultados pela SaferNet vai dos 10 aos 18, com prevalência da faixa dos 14 aos 18 e com a seguinte distribuição de gênero: $56 \%$ (feminino) e $44 \%$ (masculino) ${ }^{138}$.

Enquanto a SaferNet Brasil enfatizou as crianças e adolescentes inseridas no sistema educacional, a TIC Criança reduziu seu escopo e lançou seu olhar para um grupo etário, considerando crianças que não estão matriculadas em escolas.

A respeito dos dados obtidos pela pesquisa da SaferNet Brasil, vale, ainda, uma observação: com o método de preenchimento de formulário on-line, os pesquisadores partem do pressuposto óbvio de que os participantes da pesquisa são usuários frequentes ou eventuais da internet, podendo assim se aprofundar em questões relativas aos hábitos de navegação tais como local e tempo de acesso, interação em redes sociais, insegurança etc. Além disso, a ausência de um pesquisador in loco e o sigilo do formulário provavelmente evitaram respostas condicionadas por compreensíveis pudores e vergonhas. Por outro lado, o preenchimento on-line não evita a possibilidade de que outra pessoa tenha respondido a pesquisa no lugar da criança ou do adolescente.

\footnotetext{
${ }^{137}$ Pesquisa TIC Crianças 2009, p. 12.

${ }^{138}$ Safernet Brasil, op cit, p. 6.
} 
Para ilustrar os dados quantitativos a seguir apresentados, serão utilizados, ainda, dados qualitativos contidos no Relatório do Círculo dos Direitos da CPP Brasil ${ }^{139}$ (Pesquisa CPP), pesquisa desenvolvida no âmbito do já mencionado Programa CPP, executado pelo IICRD no Brasil entre os anos de 2009 e 2011, com financiamento da Agência Canadense de Desenvolvimento Internacional (CIDA). Este relatório, ainda não publicado, estará em breve disponível on-line para livre acesso.

A coleta dos dados qualitativos da Pesquisa CPP foi realizada ao longo dos anos de 2009 e 2010, por facilitadores de três ONGs que aplicaram a metodologia de pesquisaação Círculo dos Direitos ${ }^{140}$ com crianças e adolescentes em 14 comunidades-piloto nos estados do Maranhão e São Paulo, por pesquisadores brasileiros e canadenses contratados pelo IICRD e pela autora da presente pesquisa. Os procedimentos de coleta envolveram grupos focais, sessões do Círculo dos Direitos (que incluíram aplicações de questionários a respeito do uso da TIC) e conversas em grupo realizadas em eventos do Programa.

A Pesquisa CPP foi realizada com 277 crianças e adolescentes participantes do Círculo dos Direitos, sendo 182 crianças e adolescentes do Maranhão: 109 meninas e 73 meninos entre 9 e 18 anos de idade; 44 crianças e adolescentes de São Paulo: 23 meninas e 21 meninos entre 9 e 15 anos de idade e 51 crianças e adolescentes de Santo André: 27 meninas e 24 meninos entre 6 e 14 anos de idade.

Alguns dados quantitativos e qualitativos também destacados no Relatório do Círculo dos Direitos e aqui citados foram coletados no âmbito de uma pesquisa realizada por pesquisadores do IICRD como parte de uma pesquisa mais ampla da ONG Plan International (a Pesquisa BIAAG). A pesquisa mais ampla denomina-se "Porque eu sou uma menina" e, periodicamente, publica relatórios contendo investigações a respeito da situação de crianças e adolescentes do sexo feminino no mundo. O IICRD participou da pesquisa Because I Am A Girl 2010 ("Porque eu sou uma menina" - Pesquisa BIIAG), já

\footnotetext{
${ }^{139}$ CURRIE, Vanessa. Relatório do Círculo dos Direitos...

140 “O Círculo dos Direitos é um processo de pesquisa-ação e de planejamento intencional, centrado na criança e no adolescente, que apoia a inovação social e uma responsabilidade maior para as crianças e suas famílias. Esta metodologia reflexiva, que parte das perspectivas das próprias crianças, ajuda atores sociais comunitários, agências governamentais e formuladores de políticas a desenvolver políticas, programas e sistemas de monitoramento integrados, construindo a partir dos pontos fortes locais para tratar dos desafios enfrentados pelas crianças, seus pares, suas famílias e comunidades." CURRIE, op cit, p. 18.
} 
mencionada, com o capítulo "Meninas Adolescentes Brasileiras e suas Realidades em um Mundo Virtual"141.

A Pesquisa BIAAG contou com a participação de parceiros envolvidos nas atividades da CPP. Foram realizadas avaliações quantitativas e qualitativas, sendo que um grupo consultivo de adolescentes foi formado para ajudar a desenvolver questões de pesquisa; 4 grupos focais foram realizados, com 44 meninas entre 10 e 14 anos, e 49 meninos da mesma faixa etária em três diferentes localidades, na cidade de São Paulo e no município de Santo André, com crianças e adolescente de escolas públicas e particulares, e uma pesquisa on-line foi realizada por meio do site www.netica.org.br/cpp-brasil.

Em comum, todas as pesquisas abaixo colacionadas e discutidas colheram os dados diretamente a partir de entrevistas ou questionários preenchidos diretamente por crianças e adolescentes. São pesquisas sérias, feitas por instituições com diferentes propósitos e visões de mundo, mas nas quais houve a preocupação de ouvir os sujeitos interessados; estes trabalhos estão, pois, em consonância com as ideias sobre participação e desenvolvimento de crianças e adolescentes, desenvolvidas no capítulo anterior.

Também trago para ilustração alguns exemplos capturados em situações e diálogos que vivenciei com crianças e adolescentes durante os inúmeros encontros com diversos grupos de que tive a oportunidade de participar durante as atividades do Programa CPP.

Feitas estas considerações preliminares, destaco alguns dados relevantes para a caracterização dos usos da TIC por crianças e adolescentes no Brasil, que reforçam a relevância da pesquisa e da necessidade de elaboração de estratégias de enfrentamento da violência sexual mediada pela TIC.

De acordo com a TIC Domicílios, o percentual de brasileiros que declararam ter acesso à internet atingia, em 2010, cerca de 45\%. Na faixa etária dos 10 aos 15 anos, o percentual sobe para $68 \%$ e atinge o pico de $78 \%$ entre os jovens de 16 a 24 anos $^{142}$..

\footnotetext{
${ }^{141}$ PLAN INTERNATIONAL, op. cit.

${ }^{142}$ SaferNet Brasil, op. cit. p. 4. Segundo o artigo do pesquisador Flávio Rech WAGNER, incluído no relatório da TIC Domicílios, o uso da internet ainda é relativamente baixo nas regiões Norte e Nordeste: $30 \%$, contra $45 \%$ no Sudeste e $43 \%$ no Sul. Na comparação entre zona rural e zona urbana, a diferença é de $25 \%$, sendo $43 \%$ usuários em meio urbano e $18 \%$ em regiões rurais A assimetria é explicada por razões sócio-econômicas e também por questões de ordem técnica, dadas as dificuldades de instalação de redes e
} 
De acordo com a TIC Criança, 57\% das crianças entrevistadas já tomaram contato com um computador. Dessas, $29 \%$ utilizaram alguma vez a internet - o percentual cai para $18 \%$ em zona rural. Na comparação por classe social, $89 \%$ crianças da classe A navegam na internet contra apenas $8 \%$ das classes D-E ${ }^{143144}$.

Segundo a pesquisa da Safernet, os locais de preferência para o acesso à internet das crianças e adolescentes questionadas são as denominadas lan houses (48,75\%), seguido do computador em área comum do domicílio (48,36\%) e computador particular instalado no quarto $(39,29 \%)$. No questionário, foi solicitada a menção aos dois principais locais de uso da internet. Mesmo com a possibilidade de escolha dupla, escola $(25,03 \%)$ não teve percentual expressivo, ficando atrás da casa dos amigos $(28,59 \%)^{145}$. Nos dados obtidos pela TIC Criança, os locais favoritos relativos à faixa etária entre 5 e 9 anos foram respectivamente domicílio $(49,9 \%)$, escola $(27 \%)$ e lan houses $(22 \%)^{146}$.

Para as crianças entre 5 e 9 anos, o local de acesso favorito é o domicílio. Os jogos são apontados pela pesquisa TIC Crianças como atividade principal realizada no computador (97\% das crianças entrevistadas) ${ }^{147}$. Antes da alfabetização, crianças parecem utilizar a TIC mais como ferramenta de recreação do que de comunicação. Apesar de as crianças, mais e mais, aprenderem rapidamente a utilizar o computador mesmo sem a presença dos pais, são eles que fornecem os jogos a serem jogados off-line ou providenciam o acesso on-line para sua utilização. Ainda assim, a porcentagem de $22 \%$ de crianças de 5 a 9 anos que preferem a lan house é significativa, uma vez que nestes locais encontram-se, em geral, desprotegidos e não recebem orientação.

A opção pela lan house como local preferido para acesso cresce quando se examinam as preferências dos adolescentes: quase 50\% apontam estes estabelecimentos como um de seus locais preferidos, e a pesquisa TIC Domicílios indica que 33\% dos

operacionalização da banda larga em determinadas regiões. WAGNER, Flávio R. "Inclusão digital, inovação e universidades" In Pesquisa TIC Domicílios 2010, p. 97.

${ }^{143}$ Pesquisa TIC Crianças 2009, p. 31-32. Na Pesquisa TIC Crianças 2010, os resultados variaram dentro da margem: $51 \%$ das crianças fez uso do computador e $27 \%$ da internet. É importante notar que a pesquisa buscou diferenciar o uso do computador e o uso da internet. O acesso à internet ainda é caro no Brasil, em especial via banda larga, tecnologia que permite a transmissão de dados em maior velocidade, o que explica o fato de muitas famílias já possuírem computador, mas não acesso à internet.

${ }^{144}$ Pesquisa TIC Crianças 2010, texto "Coletiva de Imprensa”, p.10.

${ }^{145}$ Safernet Brasil, op. cit, p.7

${ }_{146}$ Pesquisa TIC Crianças 2009, p.35.

${ }^{147}$ Idem, pg.33-34. Note-se advertência contida no relatório sobre a não especificação, pelas crianças, sobre se jogavam on-line ou off-line. 
usuários de 10-15 anos acessam a internet na lan house, e similares 35\% dos usuários de 16-24 anos. Estes jovens usuários, que acessam a internet pela lan house como local mais frequente apontam como motivos: jogar jogos de computador (35\% das pessoas de 10 a 15 anos; para se divertir (49\% dos usuários de lan house de 10 a 15 anos e $41 \%$ na faixa de 16 a 24 anos; e para encontrar pessoas (na faixa de 10 a 15 anos, 27\%; e 25\% dos usuários entre 16 a 24 anos) $)^{148}$.

Como se vê, apesar da crescente campanha pela inclusão digital de crianças e adolescentes nas escolas e da instalação de telecentros, para muitas delas a lan house é o único local de acesso à internet rápida, o que lhes permite jogar jogos on-line, usar redes sociais e outras atividades on-line, inclusive pesquisas para a escola. Além disso, na escola há pouco tempo disponível para a utilização da internet, e o uso é controlado. Na lan house, a liberdade de uso é muito maior. Além disso, como apontam os dados acima, "em comunidades com poucas oportunidades de lazer e recreação, as LAN houses estão se tornando centros de jovens, já que fornecem um local para a socialização e a interação com seus pares e com os membros de suas comunidades, tanto on-line como off-line" ${ }^{149}$.

É importante notar, ainda, que o uso da lan house é tanto maior quanto mais desprivilegiada a classe social a que pertence a criança ou o adolescente. Uma pesquisa realizada em 2009 no Grande ABC para contagem e caracterização de meninos e meninas delnas ruas demonstrou que o custeio de acesso à internet em lan houses é um dos destinos do dinheiro que as crianças e adolescentes ganham em pequenos bicos ou pedindo esmolas nas ruas ${ }^{150}$.

Além disso, as lan houses instaladas em locais de baixa renda são locais cujas instalações são inseguras (muitos são clandestinos, não possuindo alvará de funcionamento), e nos quais não são tomadas medidas de segurança como o registro dos usuários, permitindo-se ainda a frequência de crianças de qualquer idade, mesmo sem a

\footnotetext{
${ }^{148}$ Percentuais sobre o total de usuários da Internet que indicaram lan house como local mais frequente. Pesquisa TIC Domicílios 2010, p.445.

${ }^{149}$ CURRIE, op cit p. 45.

${ }^{150}$ Projeto Grande ABC integrado: crianças e adolescentes em situação de rua : tecendo uma rede de proteção integral do direito à convivência familiar e comunitária / coordenação de Dagmar Pinto de Castro, Judith Zuquim, Anderson Rafael Nascimento. São Bernardo do Campo : Fundação Projeto Travessia : Universidade Metodista de São Paulo, 2009. p. 191
} 
presença de responsáveis ${ }^{151}$. Além disso, e exatamente por serem locais pouco protegidos, as lan houses são locais atraentes para a prática de tráfico de drogas ${ }^{152}$ e para adultos interessados em aliciar crianças e adolescentes para o abuso, a exploração sexual ou o tráfico internacional. Ou seja, a vulnerabilidade de crianças e adolescentes ao aliciamento e ao abuso on-line aumenta quando o local de uso mais frequente da internet é a lan house, já que estão mais expostas e não têm praticamente nenhuma supervisão ou orientação.

Adolescentes da cidade de São Paulo, moradores de uma favela localizada na Zona Sul da cidade relataram, ainda, além do hábito de "matar aulas" para ir à lan house, uma prática chamada de "Corujão", em que os proprietários das lan houses fecham as portas às 10 horas da noite e só as reabrem na manhã do dia seguinte, e os adolescentes passam a noite jogando jogos on-line.

\begin{abstract}
"Os proprietários das LAN houses pedem apenas o consentimento dos pais para que os jovens pernoitem no local. Contudo, os jovens explicaram que eles podem pedir a assinatura de qualquer pessoa na rua, e a autorização é aceita pelos proprietários. Como os pais podem desaprovar o fato de seus filhos ficarem acordados a noite inteira para jogar ou conversar com amigos pela internet, muitos dizem aos pais que dormirão na casa de um amigo" ${ }^{\text {153. }}$.
\end{abstract}

Quando questionadas a respeito, crianças e adolescentes são capazes de identificar com clareza riscos e benefícios da utilização da lan house, tanto on-line quanto off-line, assim como identificam locais mais ou menos seguros para a utilização:

\footnotetext{
"A LAN house é positiva e negativa. Lá as pessoas influenciam a se viciar em internet e jogos, orkut, msn. Muitas crianças não vão pra escola pra ficar na LAN house. Mas é positivo porque lá a gente pesquisa." (sic) (Menina, 12 anos)
}

\footnotetext{
${ }^{151}$ ECA, artigos 70 e ss.

${ }^{152}$ Deixo claro, desde já, meu posicionamento a favor da descriminalização total do uso e da produção das drogas atualmente consideradas ilícitas (seguido de sua regulamentação e controle, conforme se dá com a produção de drogas legais, como o álcool, o tabaco e os medicamentos); isto não significa, todavia, que eu entenda que seu uso possa ser feito por crianças e adolescentes sem prejuízo de seu desenvolvimento, de modo que a presença de pessoas atualmente rotuladas como traficantes de drogas em locais onde crianças e adolescentes circulam sem a supervisão de adultos torna-se uma questão problemática, do mesmo modo que pode ser problemática a venda livre de bebidas alcóolicas em locais onde crianças circulam sem supervisão de adultos.

${ }^{153}$ CURRIE, op cit, p, 47.
} 
"Os traficantes de drogas ficavam do lado de fora da LAN house que eu frequentava." (Menina, 13 anos)

"Nas LAN houses onde monitoram o uso [da internet], nos sentimos seguros." (Criança, São Paulo)

"Agora, na LAN house do $\mathrm{Du}$, [o interesse] é só ganhar dinheiro. O Du bloqueava os sites proibidos. Agora, é uma menina de 13 anos que toma conta [do lugar], e ela não faz nada; acho que ela não sabe [sobre as ameaças on-line]." Criança, São Paulo, fevereiro de $2011^{154}$.

Com a crescente inclusão digital, proporcionada pelo acesso mais barato aos computadores de uso pessoal, à possibilidade de conexão on-line por meio de telefones celulares e tablets $^{155}$ e por iniciativas como o Plano Nacional de Banda Larga, o uso das lan houses tende a diminuir e, no futuro, a desaparecer ${ }^{156}$. Atualmente, todavia, este ainda é um local importante de acesso à internet e de socialização para crianças e adolescentes moradores das periferias. As crianças e adolescentes das classes mais privilegiadas usam a internet em suas casas estando, portanto, mais protegidas. Ainda é relevante destacar que crianças e adolescentes, conforme acima destacado, apontam a casa dos amigos como um dos locais onde acessam a internet.

\footnotetext{
${ }^{154}$ CURRIE, op cit, p. 46. A "lan house do Du" foi apontada, no início da pesquisa do Círculo dos Direitos, como um local seguro, já que o proprietário não só registrava os usuários mas também se preocupava em checar se as crianças que frequentavam o local em horário escolar não estavam "matando aula". Posteriormente, a lan house foi vendida e as crianças e adolescentes deixaram de identificá-la como segura.

${ }^{155}$ Tablet é uma espécie de computador portátil, de tamanho semelhante a um livro, muito leve e fácil de transportar, utilizado principalmente para acesso à internet e para leitura de livros eletrônicos (e-books) e outros documentos e interação em redes sociais. Outros tipos de computador portátil são os laptops, notebooks e netbooks. Os termos não têm tradução em português. A respeito, cf. Glossário, anexo.

156 “Em 2010, a pesquisa TIC Domicílios registrou a maior queda no uso das lan houses como local de acesso à Internet. Esse fenômeno é concomitante ao expressivo crescimento do uso da rede nos domicílios. Apesar disso, a lan house continua sendo o segundo local mais utilizado para acesso à rede pelos brasileiros. Ao longo dos últimos seis anos, observa-se uma mudança no padrão de local de uso da Internet. Em 2007, a pesquisa TIC Domicílios evidenciou que as lan houses eram as grandes protagonistas do acesso à rede, quando pela primeira vez este local ultrapassou o acesso domiciliar - e de maneira bastante expressiva. Enquanto $40 \%$ dos indivíduos em área urbana acessavam a Internet de suas casas, $49 \%$ da população o fazia via lan houses. A partir de 2008, a pesquisa retratou uma progressiva queda do acesso nesses recintos e, em contrapartida, a progressiva ascensão do acesso domiciliar.

Os dados de 2010 registram crescimento do acesso à Internet nos domicílios e a queda do uso de lan houses de maneira bastante expressiva em todas as regiões do país, entre todas as classes sociais, entre diferentes graus de escolaridade e entre os indivíduos com diferentes inserções no mercado de trabalho". (...)

"Embora tenha sido a queda mais expressiva da participação das lan houses desde o início da pesquisa TIC Domicílios, elas continuam sendo o segundo lugar [34\% ]que os brasileiros mais utilizam para acessar a Internet, e para uma parcela considerável da população constituem uma oportunidade para a participação cidadã e para o trânsito no mundo cultural, educacional e de lazer por meio das tecnologias de informação e comunicação". Pesquisa TIC Domicílios 2010, p.157; 138.
} 
Em décadas passadas, crianças e adolescentes reuniam-se com os amigos para brincar, jogar, ouvir música (um dos passatempos favoritos de adolescentes), ler histórias em quadrinhos.

Atualmente, passatempos comuns entre adolescentes têm sido o uso de redes sociais on-line; ouvir músicas; assistir alguns dos milhares de conteúdos disponíveis na internet, como vídeos postados por outros usuários; produzir, individual ou coletivamente, e publicar, os próprios conteúdos; e jogar jogos ${ }^{157}$.

Estas práticas, facilmente constatáveis por quem quer que conviva com adolescentes, se refletem nos dados das pesquisas: quando se depararam com a pergunta sobre as três principais atividades realizadas on-line, os sites de relacionamentos/ redes sociais foram citados por $70,93 \%$ dos jovens, com destaque para a rede social Orkut, do Google, com $79 \%$ da preferência ${ }^{158}$. Em seguida, aparecem os comunicadores instantâneos (MSN, Gtalk, entre outros) com 50, 14\%, baixar/assistir filmes e músicas $(48,44 \%)$ e jogos $(44,63 \%)^{159}$.

O que quero destacar neste ponto é o quanto a relação entre os pares é importante nas práticas on-line, refletindo, as já mencionadas tendências de adolescentes de procurar a convivência em grupo. A conexão com os amigos também se fortalece durante a adolescência. Nesta fase, algumas pessoas constroem laços de cumplicidade muito fortes, amizades que levarão para toda a vida. Adolescentes de classe média e alta, dispondo de internet em casa, mantêm-se protegidos, desenvolvendo as relações de amizade em locais privados (característica da sociedade em rede). Adolescentes de classes sociais desprivilegiadas, vivendo em regiões com poucas opções de lazer e poucos espaços privados para circular, têm nas lan houses alguns de seus locais preferidos de socialização.

\footnotetext{
157 "Entre as atividades de lazer, as que mais se destacaram na área urbana são: assistir a filmes ou Vídeos (54\%), baixar músicas (48\%), ler jornais e revistas (44\%) e jogar jogos on-line (43\%). Há destaque para a divulgação de filmes ou vídeos (em sites como o YouTube, por exemplo), atividade declarada como desenvolvida por $14 \%$ dos usuários em área urbana. Nota-se também queda expressiva da proporção de usuários em área urbana que afirmaram fazer ou atualizar blogs e fotoblogs: de 15\%, em 2009, para 9\%, em 2010. Isso pode refletir a consolidação das redes sociais como o canal preferido para manifestação de opiniões e impressões dos usuários". Pesquisa TIC Domicílios 2010, p. 162.

${ }^{158}$ Antes proibido para menores de 18 anos - proibição burlada pelos adolescentes - o Orkut passou no segundo semestre de 2010 a aceitar cadastros de usuários a partir dos 14 anos.

${ }^{159}$ SaferNet Brasil op cit, p.10.
} 
Estes dados dialogam com a importância da participação e de sua relação com o desenvolvimento, questões que serão desenvolvidas mais adiante. E são reforçados por outros dados: segundo a pesquisa da Safernet, o aprendizado do uso da TIC, por exemplo, em geral ocorre sem a "mediação de pais e professores": 33,68\% aprenderam sozinhos e $18,24 \%$ com amigos. A escola é citada por apenas 8,78\% dos alunos. É um percentual similar ao daqueles que informam ter aprendido a navegar em lan houses $(6,48 \%)^{160}$.

Apesar disso, as crianças e adolescentes não se sentem capazes de, sozinhas, ajudarem as outras a usar a TIC com segurança. A Pesquisa BIAAG, por exemplo, realizada on-line com crianças e adolescentes, "concluiu que $86 \%$ das meninas e $61 \%$ dos meninos disseram que nunca haviam alertado seus amigos ou outra pessoa a respeito de ameaças on-line. O consenso geral pareceu ser que eles não podem ensinar segurança online para os outros, quando eles próprios estão enfrentando as ameaças da TIC de forma insegura" ${ }^{\prime 161}$.

Nos grupos focais, as crianças e adolescentes relatam que não se sentem seguros para alertar os amigos porque entendem que seu comportamento não é seguro:

"É difícil dar conselhos se você mesmo está fazendo a coisa errada." (Menino, Santo André)

"Eu falaria sobre o que é certo ou errado, mas ao mesmo tempo, eu não me levaria a sério porque eu também faço coisas erradas." (Menino, Santo André)

Muitas vezes não há sequer abertura, no ambiente escolar, para abordar estas questões, entre os colegas. Como já mencionado, o bullying é uma realidade nas escolas, independente da classe social. Dentre os "alvos" preferidos do bullying, estão adolescentes "cdfs" (muito estudiosos, atualmente também chamados de "nerds") "certinhos" ou tímidos. Abordar na escola questões como o uso seguro da internet pode ser apenas mais um motivo para ser "zoado" pelos colegas ${ }^{162}$.

\footnotetext{
${ }^{160}$ SaferNet Brasil, op cit., p. 11

${ }^{161}$ CURRIE, Relatorio do Circulo dos Direitos... p. 71.

${ }^{162}$ Ilustro esta afirmação com o seguinte relato: no âmbito do Programa CPP, crianças e adolescentes envolvidos no Círculo dos Direitos tinham que eleger um desafio e estabelecer um plano de ação para enfrentá-lo. Os adolescentes de uma das instituições que implementava a metodologia do Círculo dos
} 
A importância da promoção do aprendizado entre pares se reforça, ainda, por outra razão: muitas crianças e adolescentes parecem não confiar em seus pais para contar a eles quando algo errado acontece on-line. Segundo a Pesquisa BIAAG, quando perguntados "se contam a seus pais quando acontece alguma coisa errada on-line, apenas 35\% das meninas e $27 \%$ dos meninos responderam que sim" ${ }^{\text {"63 }}$.

“Meus pais? Não, porque eu sei mais.” (Menino, São Paulo)

Além de identificarem que sabem mais do que seus pais sobre os problemas que ocorrem on-line, as respostas que os pais têm dado aos filhos, quando estes os procuram para relatar algo ruim que tenha acontecido on-line:

"Quando eu conto para a minha mãe, às vezes eu levo uma bronca. Ela não entende.” (Menina, Santo André)

"Eu não conto nada para a minha mãe, porque posso ter problemas. Mas se ela descobrir, eu vou ter problemas do mesmo jeito." (Menina, São Paulo)

Assim, "apesar de reconhecerem que, como adultos, seus pais podem lhes oferecer sabedoria e orientação, as crianças os veem como incapazes de compreender as complexidades da TIC. De forma interessante, algumas crianças e adolescentes pareciam não contar seus problemas aos pais por medo de serem castigadas, em vez de reconhecer

Direitos escolheram como desafio a conscientização dos amigos, buscando criar uma rede de apoio para sua proteção, já que seus pais tinham muita dificuldade para orientá-los a respeito.

Para concretizar este plano, identificaram três diferentes momentos para a ação: amigos da própria instituição, amigos da escola e amigos do bairro. As ações para conscientização dentro da instituição se iniciaram com tranquilidade: lá, o clima é amigável e não há prática de bullying. A grande dificuldade era pensar em como abordar esta questão com os amigos (colegas, na realidade) da escola. Durante uma reunião com os adolescentes, para discussão a respeito dessas e de outras questões, iniciamos (eu, a educadora da instituição e uma pesquisadora do IICRD que se encontrava no local) com algumas perguntas sobre como era a vida deles, como era a vida em casa, o bairro, a escola, quais eram as opções de lazer, etc. Os adolescentes informaram que em algumas escolas da região havia violência entre os alunos, as coisas estavam sempre quebradas e sujas: nenhuma novidade quando se pensa na descrição de uma escola pública localizada na periferia da cidade de São Paulo.

Após os adolescentes apresentarem o plano de ação, e contarem a respeito da dificuldade em dar o próximo passo ("conscientizar os amigos da escola"), propusemos uma "tempestade de ideias" para pensar em como seria possível executá-lo. Perguntei a eles se não seria possível fazer uma apresentação na sala de aula, ou mesmo puxar conversa com os colegas na escola a respeito do assunto. Um dos adolescentes então me respondeu categoricamente: "nem pensar". Segundo ele, seria certamente ridicularizado ou apanharia dos colegas caso viesse falar a respeito disso na sua escola. Cabe salientar que, dentro da metodologia, adultos têm o papel de pensar as estratégias junto com as crianças e adolescentes, orientando-os, e buscando envolver pais, professores, comunidade e outras instituições na execução do plano de ação.

${ }^{163}$ CURRIE, Relatório do Círculo dos Direitos... p. 17. 
que seus pais as amam e apoiam, e que eles prefeririam saber que elas estão seguras, e não correndo riscos" $" 164$.

A mesma questão aparece expressa nas falas das adolescentes do sexo feminino entrevistadas nos grupos focais da pesquisa BIAAG, que “(...) expressam claramente um desejo de que seus pais se envolvam mais no monitoramento de seu comportamento, dando-lhes conselhos e ajudando-as a determinar o que é seguro e o que não é seguro online. Ironicamente, muitas das meninas que recorreram a um dos pais quando alguma coisa ruim aconteceu on-line indicaram que foram repreendidas, ao invés de serem orientadas. Isto aconteceu de forma igual em todos os grupos focais. Isto provavelmente acontece porque muitos pais sabem muito pouco sobre os ambientes on-line nos quais as meninas navegam" 165 .

Como dado interessante, aparece também o fato de adolescentes de uma escola particular de Santo André terem apontado como um adulto confiável para orientá-los a respeito de questões de segurança na TIC o Professor de TI. Isso reforça a impressão de que crianças e adolescentes de classes média e alta estão mais protegidos por contarem com pais com mais instrução, mais recursos e educação formal de mais qualidade, que inclui o aprendizado do uso da tecnologia.

Em contraponto, o monitor de TI de uma instituição de atendimento de meninos e meninas de rua de Santo André, que atende crianças e adolescentes em horário complementar à escola, nunca tinha tido a oportunidade de conversar a respeito da segurança on-line e de refletir sobre como orientar seus alunos, conforme relatou durante uma oficina do Programa CPP lá realizada.

Essas impressões são novamente reforçadas pelos dados da pesquisa TIC Domicílios. Segundo a pesquisa, o custo elevado é apontado por $74 \%$ dos domicílios que não possuem computador como a principal barreira para aquisição. Mas a falta de interesse e a falta de habilidade são motivos apontados respectivamente por $38 \%$ e $26 \%$ dos domicílios sem computador. "Isso indica que, além de questões estruturais que remetem ao custo do equipamento, a ampliação da posse de computador nos domicílios

\footnotetext{
${ }^{164}$ CURRIE, op cit, p. 70.

${ }^{165}$ PLAN INTERNATIONAL, op cit., p. 4.
} 
depende não somente do acesso às TIC propriamente dito, mas também do desenvolvimento de habilidades a partir de uma maior alfabetização digital da população" 166 .

Outro fato que dialoga com essas impressões, é o de que a inclusão digital está, mais e mais, alcançando as classes sociais mais baixas. A pesquisa TIC Domicílios indica que há maior presença na rede de brasileiros com menor grau de escolaridade e de classes sociais mais baixas. Nos últimos seis anos, a proporção de domicílios com computador mais que dobrou nas áreas urbanas.

É preciso apontar, porém, que o fato de crianças e adolescentes acessarem a internet em casa, apontado alguns parágrafos acima, não significa que, necessariamente, tenham mais supervisão desse uso, tampouco o fato de seus pais serem "digitalmente letrados" é garantia de sua proteção. Muitos pais zelosos supervisionam e orientam os filhos no uso da TIC, regulando o tempo de permanência no computador, instalando programas (softwares) que bloqueiam sites indevidos e, por vezes, até mesmo gravando suas conversas on-line em comunicadores instantâneos. Outros, apesar da presença do computador dentro de suas casas, ainda não sabem orientar os filhos - por serem iletrados digitais ou por não terem tanta desenvoltura no uso da TIC $^{167}$; outros, ainda, por passarem muitas horas fora de casa, trabalhando, não terão ciência ou capacidade de controlar as atividades de seus filhos on-line; outros mais, não prestarão atenção a este e também a nenhum outro aspecto da vida de seus filhos. Desse modo, o letramento digital per si é instrumento, é informação relevante, mas informação não é suficiente para formar pais competentes para guiar os seus filhos nos meandros do mundo (real ou virtual).

166 Pesquisa TIC Domicílios, 2010, p. 143.

$167 \mathrm{O}$ conceito de letramento/iletramento digital (também chamado de alfabetização tecnológica e letramento eletrônico, entre outros) inclui não só o conhecimento técnico do uso da tecnologia, mas também a "habilidade para construir sentidos a partir de textos que mesclam palavras que se conectam a outros textos, por meio de hipertextos, links e hiperlinks; elementos pictóricos e sonoros numa mesma superfície textos multimodais. Ele precisa também ter capacidade para localizar, filtrar e avaliar criticamente informação disponibilizada eletronicamente, e ter familiaridade com as normas que regem a comunicação com outras pessoas através dos sistemas computacionais". (FONSECA, Magna de Carvalho. Letramento Digital: uma possibilidade de inclusão social através da utilização de software livre e da educação à a distância. Monografia (curso de Pós Graduação "Lato Sensu” da Fundação de Apoio ao Ensino, Pesquisa e Extensão - FAEPE da Universidade Federal de Lavras). Lavras, 2005 Disponível em: http://www.ginux.ufla.br/files/mono-MagnaFonseca.pdf. Download em 17 Abr 2011, p.21).

Apesar do iletramento digital, muitos pais já tem ciência da importância do computador e da internet para a inclusão no mundo do trabalho, além de cederem, também, às pressões dos filhos, que querem ter acesso à tecnologia. Assim, não é incomum que o computador esteja presente na casa, mas seu único usuário seja o adolescente. 
O reclamo a respeito do monitoramento dos pais, portanto, parece ir além das questões da TIC. A discussão sobre este assunto desvela carências de cuidados que, possivelmente, acontecem em vários outros níveis e com relação a diferentes aspectos das vidas dessas crianças.

Os celulares também são parte da TIC, e nota-se, pelas pesquisas, que seu uso vem se disseminando cada vez mais rapidamente, inclusive entre crianças e adolescentes.

A pesquisa TIC Domicílios identificou que em 2010, os aparelhos celulares já estavam presentes em $84 \%$ dos domicílios brasileiros, registrando um crescimento de 6 pontos percentuais em relação a $2009^{168}$. A Pesquisa TIC Crianças, por sua vez, identificou que " $64 \%$ das crianças de cinco a nove anos já usaram um telefone celular, e $14 \%$ já possuem um aparelho" 169 .

No relatório, indica-se que, “apesar da proporção de posse de celulares entre crianças ser menor que na população geral, $14 \%$ e 59\%, respectivamente, o índice apresentado entre os menores de nove anos é bastante expressivo. Deve-se levar em consideração que os entrevistados ainda não têm decisão de compra para optarem por um aparelho próprio; assim, dependem da decisão dos pais. Entre as crianças de nove anos, o valor de posse de celular alcança seu patamar mais alto e está presente entre $24 \%$ dos respondentes".

As crianças utilizam o celular principalmente para diversão: $88 \%$ brincam com jogos, e 64\%, declararam usar o aparelho para falar com alguém; 60\% utilizam o celular para ouvir música" ${ }^{170}$.

Importante sublinhar que os resultados das pesquisas ainda não captaram com certeza o crescimento, perceptível em uma análise empírica, do uso dos celulares conectados à internet. Na Pesquisa SaferNet, por exemplo, somente 5,31\% disseram utilizar o celular como ferramenta de navegação, que só fica à frente dos telecentros $(2,57 \%)$. Sabe-se, porém, que o uso da internet via celular é crescente.

\footnotetext{
${ }^{168}$ Pesquisa TIC Domicilios 2010, p. 171

${ }^{169}$ Note-se que a pesquisa diferencia uso e posse de aparelhos celulares. O telefone muitas vezes pertence a um indivíduo da família, contudo é de uso coletivo. Pesquisa TIC Crianças 2009, p 36-37.

${ }^{170}$ Pesquisa TIC Crianças 2009, p. 37.
} 
Por fim, os dados indicam que também o uso da internet começa muito cedo: os participantes da Pesquisa SaferNet relataram ter dado seus primeiros passos na internet entre os 10 e 13 anos (52,1\%), mas o percentual dos que começaram entre 5 e 9 anos é expressivo (33,68\%). A Pesquisa TIC Crianças $2009^{171}$ informa dados parecidos com os da Safernet: $29 \%$ das crianças de 5 a 9 anos declararam já ter utilizado a internet. Na área rural, esses índices de uso são reduzidos para 18\%, ou seja, $82 \%$ dos respondentes nunca utilizou a Internet nessas áreas.

Espera-se, com os dados quantitativos e qualitativos acima, ter sido possível caracterizar, de forma suficiente para os fins desta pesquisa, alguns aspectos do uso da tecnologia pelas crianças e adolescentes brasileiras.

\footnotetext{
${ }^{171}$ Pesquisa TIC Crianças 2009, p. 31.
} 


\section{Capítulo 2 - Violência sexual contra crianças e adolescentes mediada pela TIC}

No capítulo anterior, buscou-se caracterizar a sociedade em rede, com foco nas mudanças na comunicação e o impacto na sociabilidade, a partir, especialmente, da abordagem do sociólogo Manuel CASTELLS. Buscou-se, ainda, caracterizar as vivências de crianças e adolescentes com a TIC e a penetração que a tecnologia tem em sua vida cotidiana, utilizando-se, para tanto, alguns dados quantitativos e qualitativos de pesquisas feitas no Brasil, especialmente pesquisas que tenham ouvido diretamente as crianças e adolescentes.

Essas pesquisas indicam que, apesar de serem "nativos digitais" e de terem grande facilidade no aprendizado e manejo da TIC, crianças e adolescentes precisam de orientação, informação e de uma "rede de segurança" para que possam utilizar a TIC de modo seguro.

A necessidade desta rede de proteção será tanto maior quanto maiores os fatores de risco que a criança/adolescente apresentar, fatores de risco esses que, em grande medida, não diferem de maneira substancial dos fatores de risco para violência que compõem as circunstâncias de vida de milhares de crianças, adolescentes e jovens vítimas de violência, seja ela a violência real, física ou psicológica, seja ela a violência estrutural resultante de uma perversa inclusão no sistema capitalista globalizado.

Os resultados das pesquisas SaferNet e de ambas as Pesquisas TIC Crianças corroboram a crescente preocupação com o preparo de crianças e adolescentes para o uso seguro da TIC.

Esse é o pano de fundo mais amplo para a discussão sobre a violência sexual contra crianças e adolescentes mediada pela TIC.

Se são claros e inúmeros os benefícios das novas tecnologias, como o acesso livre à informação, a liberdade de expressão, a expansão da capacidade de comunicação, o nascimento de novas redes de sociabilidade, a troca de ideias e de mobilização, entre outras, inúmeros, são, também, os riscos que apresenta. 
Antes de apresentar o objeto e suas problematizações, é necessário estabelecer algumas definições importantes de modo que seja possível situar os mencionados riscos no contexto maior do que se entende por violência sexual, estabelecendo-se, assim, o sentido e os limites da expressão violência sexual mediada pela TIC, tanto do ponto de vista jurídico-penal quanto do ponto de vista das ciências sociais e da criminologia.

$\mathrm{Na}$ primeira parte deste capítulo são apresentados e discutidos os conceitos de violência sexual, abuso sexual, exploração sexual, pedofilia e pornografia infantil. Também se distinguem as categorias utilizadas para referência aos autores de delitos sexuais contra crianças e adolescentes, que, no senso comum (inclusive, e principalmente, pela imprensa), são indistintamente nomeados como "pedófilos".

Na segunda parte, são apresentados os conceitos de violência sexual mediada pela TIC: o abuso sexual on-line e o aliciamento on-line (grooming), condutas praticadas por adultos em interação com as crianças e adolescentes.

Lembro, novamente, que o ponto de vista que guia esta pesquisa é o da prevenção vitimal. Não são discutidas aqui, portanto, questões dogmáticas que são, indiscutivelmente, dignas de atenção, pois a discussão ultrapassaria os limites da pesquisa proposta. Um estudo doutrinário mais aprofundado, no âmbito dogmático, a respeito dos novos crimes do ECA seria desejável, para buscar soluções de interpretação que atendam aos direitos de crianças, adolescentes e dos acusados de crimes. 


\subsection{Violência sexual contra crianças e adolescentes: conceitos-chave.}

Antes de apresentar o conceito de violência sexual mediada pela TIC, com foco na proteção dos direitos de crianças e adolescentes ao desenvolvimento e, especificamente, ao desenvolvimento saudável de sua sexualidade, é importante apresentar alguns conceitos relevantes que, se não dizem respeito especificamente aos riscos que entram pelas portas do mundo on-line, situam a questão aqui discutida dentro de um panorama mais amplo, que é o da violência sexual contra crianças e adolescentes.

A distinção entre violência, abuso e exploração sexual tem relevância, assim como a definição de pornografia infantil. Dentro desta distinção, há ainda uma variedade de termos, que incluem a prostituição, o turismo sexual e o tráfico para fins sexuais (ligados à exploração sexual), além da diferenciação entre abuso sexual intra e extrafamiliar e da "pedofilia". Outra questão importante é a distinção entre diferentes tipos de autores de delitos sexuais contra crianças e adolescentes, que costumam ser, indistintamente, nomeados como "pedófilos".

É vasta a literatura que apresenta tal caracterização, e, é preciso dizer, um tanto repetitiva dos textos de tratados internacionais. Para os fins aqui propostos, que são de simples fixação de conceitos, optou-se pela concentração em alguns artigos e obras representativos de diferentes saberes (psicologia, ciências sociais, criminologia e direito), apresentando-os de modo sucinto.

Apesar desta preocupação com a precisão conceitual, porém, é bom lembrar que todos os fenômenos a serem apresentados estão interconectados e, muitas vezes, ocorrem de forma convergente com relação a uma única criança; ou seja, no pior cenário possível, uma única criança pode ter sido vítima de tráfico para um local onde será explorada sexualmente de forma comercial - prostituição-, dentro de um contexto de turismo sexual e, finalmente, pode ter suas imagens exploradas e comercializadas on-line - pornografia infantil.

Pelo fato de a violência sexual contra crianças e adolescentes ser uma categoria central para este trabalho, são examinadas não só as definições que vêm sendo construídas pela literatura especializada na temática (que inclui leituras de disciplinas antropológicas, sociológicas, do serviço social, da psicologia etc) mas também são trazidas as noções 
extraídas da doutrina dogmática-jurídico-penal, em especial a partir do conceito do bem jurídico protegido nos crimes sexuais contra crianças e adolescentes, buscando construir uma compreensão interdisciplinar da questão.

Com relação às demais categorias (abuso, exploração sexual, pedofilia, pornografia infantil etc), apontam-se, somente, quanto ao aspecto jurídico, os tipos penais da legislação penal brasileira que foram considerados pertinentes aos fenômenos discutidos.

\subsubsection{Violência, abuso e exploração sexual contra crianças e adolescentes}

\subsubsection{Violência sexual}

A literatura especializada em violência sexual contra crianças e adolescentes parece unânime em considerar a violência sexual como gênero, do qual fazem parte o abuso sexual (intra e extrafamiliar) e a exploração sexual (que, por sua vez, se divide, segundo a literatura, em quatro modalidades: pornografia, o turismo sexual, o tráfico para fins sexuais e a prostituição).

A violência sexual é "elemento constitutivo/conceitual e, portanto, explicativo da natureza, de todas as situações em que crianças e adolescentes são vitimizados sexualmente" ${ }^{172}$. E, conforme DOS SANTOS, IPPOLITO e NEUMANN, a violência sexual é "não só numa violação à liberdade sexual do outro, mas também (...) violação dos direitos humanos da criança e do adolescente. É praticada sem o consentimento da pessoa vitimizada. Quando cometida contra a criança, constitui crime ainda mais grave. Pode ser classificada como intrafamiliar, extrafamiliar, e exploração comercial sexual" ${ }^{173}$.

Tomarei emprestado o caminho proposto por LIBÓRIO e CASTRO para apresentar a definição de violência e, posteriormente, de violência sexual. As autoras

\footnotetext{
${ }^{172}$ FALEIROS, Eva T. Silveira. A Exploração sexual comercial de crianças e adolescentes no mercado do sexo. In LIBÓRIO, Renata Maria Coimbra \& SOUSA, Sônia M. Gomes (organizadoras). A Exploração Sexual de Crianças e de Adolescentes no Brasil. Reflexões teóricas, relatos de pesquisas e intervenções psicossociais. São Paulo: Casa do Psicólogo. Goiânia: Universidade Católica de Goiás, 2004, p 73-98; p.75.

${ }^{173}$ DOS SANTOS, Benedito Rodrigues; IPPOLITO, Rita; NEUMANN, Marcelo (orgs). Guia Escolar: métodos para identificação de sinais de abuso e exploração sexual de crianças e adolescentes. Brasília: Presidência da República, Secretaria Especial dos Direitos Humanos, 2004; p. 36.
} 
partem, inicialmente, de artigo publicado por Marilena CHAUí em $1999^{174}$, no qual a filósofa define violência, em contraposição à ética, como "um ato de brutalidade, sevícia e abuso físico e/ou psíquico contra alguém [que] e caracteriza relações intersubjetivas e sociais definidas pela opressão e intimidação, pelo medo e o terror. A violência se opõe à ética porque trata seres racionais e sensíveis, dotados de linguagem e de liberdade, como se fossem coisas, isto é, irracionais, insensíveis, mudos e inertes ou passivos".

A autora especifica um pouco mais esta violência que dessensibiliza e desumaniza os sujeitos, identificando-a com atos que desnaturalizam (uso da força para ir contra a natureza de algum ser); coagem, constrangem, torturam, brutalizam, tolhendo a espontaneidade, a vontade e a liberdade de alguém; violam a natureza de alguém ou de algo que tem valor social positivo; transgridem o que alguém ou uma sociedade define como justo e como um direito.

Partindo desta concepção, é possível identificar diversas características atribuídas, pela literatura, à violência sexual contra crianças e adolescentes. Segundo FALEIROS, a violência sexual contra crianças e adolescentes, gênero que se desdobra em múltiplas formas (polimorfa),

"(i) deturpa as relações socioafetivas e culturais entre adultos e
crianças/adolescentes ao transformá-las em relações
genitalizadas, erotizadas, violentas, criminosas, comerciais; (ii)
confunde, nas crianças e adolescentes violentados, os papéis
dos adultos, descaracterizando as representações sociais de pai,
irmão, avô, tio, professor, religioso, profissional, empregador
etc., quando violentadores sexuais, o que implica a perda de
legitimidade e de autoridade do adulto e de seus papéis e
funções sociais; (iii) inverte a natureza das relações
adulto/criança e adolescente definidas socialmente, tornando-as
desumanas em lugar de humanas; desprotetoras em lugar de
protetoras; agressivas em lugar de afetivas; individualistas e
narcisistas em lugar de solidárias: dominadoras em lugar de
democráticas; dependentes em lugar de libertadoras; perversas
em lugar de amorosas; desestruturadoras em lugar de
socializadoras". ${ }^{175}$

${ }^{174}$ CHAUÍ, Marilena. Uma ideologia perversa. Folha de São Paulo, São Paulo, 1999. Disponível em http://www1.folha.uol.com.br/fsp/mais/fs14039904.htm, acesso em 29/12/2011 (disponível somente para assinantes).

${ }^{175}$ FALEIROS, Eva T. Silveira. Repensando os conceitos de violência, abuso e exploração sexual de crianças e adolescentes. Brasília: Thesaurus, 2000 apud FALEIROS, Eva T. Silveira; RADICCHI, Lis Celia Arantes. Pedofilia, Adoecimento e crime. In Revista Juridica Consulex. Brasilia, v.14, n.315, p.35-37, fev. 2010, p. 36. 
Dialogando entre as concepções de violência de CHAUÍ e de violência sexual, de FALEIROS, pode-se dizer que a violência sexual contra crianças e adolescentes é uma forma de violência que, antes mesmo de ser caracterizada como crime, agride a ética, já que desnaturaliza o processo de desenvolvimento sexual sadio de crianças e adolescentes (que será abordado, neste trabalho, mais adiante), seja por meio do uso da força, seja por meio da coação ou do exercício de uma relação de autoridade que, naturalmente, existe entre adultos e crianças. Esta mesma relação de autoridade e de confiança também é deslegitimada a partir do momento em que é utilizada para constranger.

A violência sexual contra crianças e adolescentes tolhe a espontaneidade, a vontade e a liberdade desses sujeitos que, em lugar de exercitarem os seus direitos de ser criança e de ser adolescente, vivenciando as situações próprias de cada etapa de seus desenvolvimentos, nos tempos e espaços que, de acordo com as suas condições biopsicossociológicas, sociais e econômicas, lhe são peculiares, vivenciam, ao contrário, relações "desumanas em lugar de humanas; desprotetoras em lugar de protetoras; agressivas em lugar de afetivas; individualistas e narcisistas em lugar de solidárias: dominadoras em lugar de democráticas; dependentes em lugar de libertadoras; perversas em lugar de amorosas; desestruturadoras em lugar de socializadoras”.

A violência sexual transforma as crianças e adolescentes, sujeitos de direitos, em objeto, e transgride, de inúmeras formas, o que a sociedade atual definiu como justo e como um direito. São violados, no ato da violência sexual, os direitos à integridade física e psicológica, ao respeito e à dignidade, ao desenvolvimento físico, psicológico, moral e sexual saudáveis, somente para citar os mais evidentes.

Mais que desestruturadora e violadora, FALEIROS entende a violência sexual, quando "perpetrada por adultos contra crianças ou adolescentes, por seu caráter íntimo e relacional, (...) [como] 'organizadora' de estruturas psíquicas e sociais, principalmente nos abusos sexuais de longa duração e na exploração sexual comercial" ${ }^{176}$. [aspas no original, destaquei em itálico]

\footnotetext{
${ }^{176}$ FALEIROS, Eva T. Silveira. A Exploração sexual comercial de crianças e adolescentes no mercado do sexo ... p. 75 .
} 
O entendimento da doutrina jurídico-penal a respeito da violência sexual contra crianças e adolescentes, em certa medida, coaduna-se com as conceituações até o momento apresentadas, embora não se identifique totalmente com elas. Para chegar aos contornos do que se entende, então, violência sexual mediada pela TIC, farei um breve exame, do entendimento da doutrina criminal brasileira a respeito do bem jurídico ${ }^{177}$ tutelado em alguns crimes sexuais contra crianças e adolescentes ${ }^{178}$.

Apesar de não ligado diretamente ao delito praticado por meio do uso da tecnologia, objeto desta pesquisa, este breve estudo tem sua razão de ser, já que, enquanto gênero, o conceito de violência sexual contra crianças e adolescentes deve ser unívoco, não importando o meio pelo qual a violência é cometida. Por esta razão, somente brevemente serão especificados os demais conceitos (abuso e exploração sexual), pois, para os fins aqui pretendidos, trabalharei com a categoria ampla violência sexual.

A Lei 12.015 de 2009 deu nova redação e nova conformação a uma série de crimes do Código Penal Brasileiro (CP) envolvendo violência sexual contra adultos e crianças em suas várias formas, sendo algumas das mais marcantes mudanças a unificação dos crimes

\footnotetext{
${ }^{177}$ Apesar de amplamente utilizado, o conceito de bem jurídico, o seu conteúdo e a necessidade de sua existência/utilização são questões bastante controversas dentre os estudiosos das Ciências Criminais. Mesmo os criminólogos críticos ainda buscam um "referente material de definição de crime, capaz de exprimir a negatividade social das situações conflituais da vida coletiva nas sociedades modernas e de indicar hipóteses merecedoras de criminalização legal, admitindo que o Direito Penal ainda é necessário para solução de determinados conflitos". [itálico no original]. Enquanto isso, o conceito continua relevante, nas sociedades capitalistas e cuja organização obedece aos princípios dos Estados Democráticos de Direito, tanto como critério de criminalização de condutas quanto como objeto de proteção do Direito Penal. SANTOS, Juarez Cirino dos. Direito Penal: parte geral. $3^{\text {a }}$ ed. Curitiba:ICPC:Lumen Juris, 2008, p. 14-18. A discussão é relevante e pertinente, mas ela não pertence ao escopo deste trabalho, de modo que, sempre que o conceito de bem jurídico aparecer, nesta pesquisa, ele deve ser entendido como critério de criminalização de condutas - eleição daquelas que são consideradas como violadoras de valores sociais importantes; e objeto de proteção da norma penal (valor que se considera que merecedor de proteção penal).

${ }_{178}$ BITENCOURT, Cezar Roberto. Tratado de Direito Penal, vol 4: parte especial. 7. ed. São Paulo: Saraiva, 2011; GRECO, Alessandra Orcesi Pedro; RASSI, João Daniel. Crimes contra a dignidade sexual. 2. Ed. São Paulo: Atlas, 2001; ESTEFAM, André. Crimes Sexuais - Comentários à Lei n. 12.015/2009. São Paulo: Saraiva, 2009; NUCCI, Guilherme de Souza; MARQUES, Ivan Luís. Os contornos normativos da proteção do vulnerável prescrita pelo Código Penal (arts. 218-A e 218-B, introduzidos pela Lei 12.015/2009). Revista Brasileira de Ciências Criminais, São Paulo, v. 18, n. 86, p.9-35, set./out. 2010. Neste estudo serão examinadas especificamente as visões destes doutrinadores, que se dedicaram especificamente ao estudo dos novos tipos penais do Código Penal brasileiro instituídos pela Lei 12.015 de 2009, denominados genericamente de crimes sexuais, além das reflexões de MACHADO, em Proibições de excesso.... Embora não examine os delitos já positivados, por ter sido publicada antes desta pontual reforma do Código Penal, a escolha se justifica porque MACHADO tem um profundo conhecimento do Direito da Criança e do Adolescente, trabalhando-o de maneira extremamente coesa e integrada com o Direito Penal em busca de estabelecer um sistema em que o ECA funcione como princípio de conformação e interpretação da lei penal (op cit, p. 73) com relação aos crimes praticados contra crianças e adolescentes.
} 
de estupro (art 213) e atentado violento ao pudor (antigo art. 214) e a criação do crime de estupro de vulnerável ${ }^{179}$.

Ainda em busca da compreensão do termo violência sexual, analisemos o entendimento a respeito do bem jurídico tutelado nesses novos tipos. A respeito do artigo 217-A (estupro de vulnerável) ${ }^{180}$, BITENCOURT chama a atenção para o fato de que esses menores (vulneráveis) "foram violentados em seus mais sagrados direitos fundamentais de liberdade e dignidade humana que, por extensão, também abrangem a liberdade e dignidade sexual" ${ }^{\prime 81}$. Situa, então, o abuso sexual dentro do contexto da violência familiar (conjugal, maus-tratos infantis, abuso sexual intrafamiliar), violência esta que é multifacetada e que apresenta diversas formas, como maus-tratos físicos, psicológicos, abuso sexual, abandono e negligência na educação e formação de crianças e adolescentes.

179 "Estupro de vulnerável. Art. 217-A: Ter conjunção carnal ou praticar outro ato libidinoso com menor de 14 (catorze) anos.”. A tipificação do estupro de vulnerável pretendeu acabar com a discussão anteriormente existente na doutrina e jurisprudência a respeito da relatividade ou não da presunção de violência que era prevista quando havia relação sexual entre, por exemplo, um homem adulto e uma adolescente menor de 14 anos. Parte da doutrina considerava que esta presunção de violência era absoluta (o que tornava qualquer relação sexual com uma pessoa menor de 14 anos um estupro ou atentado violento ao pudor); parte entendia que a presunção era relativa, devendo ser examinados critérios como maturidade do menor, experiências sexuais anteriores, contexto cultural, etc, para se estabelecer se se tratava de estupro ou de relação sexual consensual, não punível. A discussão, porém, como aponta BITENCOURT, não se encerrou com a nova redação, apesar de o texto legal ser categórico ao estabelecer o limite etário vinculado a uma pena mais grave. A esse respeito, GRECO, RASSI entendem que a presunção somente é absoluta com relação á vítima menor de 12 anos (criança, conforme definição do ECA) e relativa com relação à vítima entre 12 e 14 anos (adolescente) (op.cit. p. 116); BITENCOURT também entende que há uma presunção a respeito da incapacidade de resistir por parte da criança/adolescente vítima do delito, apesar de considerar que esta presunção deve ser comprovada no caso concreto (presunção relativa). Parte da doutrina, agora, além de discutir a presunção da violência, passou também a se dedicar à interpretação do termo "vulnerável", a partir da comparação da vulnerabilidade do menor de 14 anos, que o próprio artigo oferece em seu parágrafo primeiro, com a vulnerabilidade de quem "por enfermidade ou deficiência mental, não tem o necessário discernimento para a prática do ato ou que, por qualquer outra causa, não pode oferecer resistência", ou seja, os denominados absolutamente inimputáveis. A respeito, cf BITENCOURT, op. cit, p. 94-96; p.124-127; Cf. GRECO, RASSI, op.cit. p. 111-119. MACHADO, por seu turno, advoga pela abolição da categoria da presunção de violência, considerando-a resquício de um direito penal que tutelava a moralidade pública e que enfocava um direito penal do autor, violadora da taxatividade (permite tratamento jurídico diferente: o homem "de bem" pode ser seduzido pela adolescente, mas o "pedófilo" sempre terá interferido na vontade da vítima) e, evidentemente, violadora dos direitos da vítima. Propõe a substituição desta imprecisa categoria pela da presunção de lesividade: "a lesividade de um ataque sexual concreto contra crianças e adolescentes há de ser analisada essencial, ou quase que exclusivamente, à luz dos direitos fundamentais da vítima (...) [já que] é de baixa significância, para o adulto, o dever de abstenção da prática de ato sexual de relevo contra (ou com) crianças e adolescentes, porque pode exercitar livremente sua sexualidade em relação aos demais adultos; são de altíssima significância para a integridade da vítima, as consequências do abuso, da violência ou da exploração sexual”. Op. cit, p.204-205.

${ }^{180}$ Este tipo penal abre um capítulo que contem uma série de outros crimes sexuais praticados contra crianças e adolescentes e que serão mencionados a seguir.

${ }^{181}$ BITENCOURT, op. cit, p.90. 
$\mathrm{O}$ autor apresenta o abuso sexual infantojuvenil intrafamiliar como uma das mais graves formas de violência, "pois lesa os direitos fundamentais das crianças e adolescentes, apresentando contornos de durabilidade e habitualidade"; crime este que deixa marcas na alma das vítimas. Neste contexto, traz a citação de Luciane Potter BITTENCOURT $^{182}$, entendendo a violência sexual contra crianças e adolescentes como violação de direitos humanos universais, para além de seu caráter de crime sexual.

A questão da revitimização (vitimização secundária) também é tratada pelo autor, sendo esta uma forma de violência institucional, causada pelo sistema de justiça, que viola outros direitos além dos já violados com a prática de violência sexual.

BITENCOURT entende que, apesar de o bem jurídico mediato ser a dignidade sexual (por não ser possível, ainda, falar em liberdade sexual no caso de crimes sexuais contra vulnerável, ou seja, menor de 14 anos), na verdade, o que se procura proteger é a "evolução e o desenvolvimento normal da personalidade do menor para que, na sua fase adulta, possa decidir livremente, e sem traumas psicológicos, seu comportamento sexual".

ESTEFAM, de modo similar, entende que o tipo penal do estupro de vulnerável visa proteger a liberdade sexual e o "pleno desenvolvimento das pessoas vulneráveis, ou seja, aqueles que, em face de alguma condição pessoal (transitória ou perene), não dispõem de forças ou de compreensão para resistir a um ataque contra sua dignidade sexual" Assevera, ainda, que alguns setores da doutrina consideram que, com relação ao menor de 14 anos, a tutela penal também se dirige à defesa da candura, da inocência e da falta de maturidade mental no que se refere à própria sexualidade" ${ }^{183}$. O autor se remete a esta mesma observação no exame dos demais crimes sexuais previstos no CP.

Com relação ao estupro de vulnerável, GRECO e RASSI fazem revisão doutrinária focada nas questões complicadoras da compreensão do bem jurídico, como a já mencionada questão do consentimento, mas não parecem tomar uma posição a respeito de qual seria o bem jurídico tutelado: se a moralidade sexual de crianças e adolescentes, sua liberdade sexual, seu desenvolvimento sexual ou seu equilíbrio psíquico, apenas para elencar algumas das posições doutrinárias apresentadas. O fazem, todavia, com relação

\footnotetext{
182 BITTENCOURT, Luciane Potter, Vitimização secundária infantojuvenil e violência sexual intrafamiliar, Rio de Janeiro, Lumen Juris, 2009, p. 67-8 apud BITENCOURT, op. cit, p. 91.

${ }^{183}$ ESTEFAM, André. Crimes Sexuais - Comentários à Lei n. 12.015/2009. São Paulo: Saraiva, 2009, p. 64.
} 
aos crimes de corrupção de menores, satisfação de lascívia mediante presença de criança ou adolescente, favorecimento de prostituição de vulnerável etc, ao concordar com posição doutrinária que afirma que o "bem jurídico protegido nesses casos é o bem-estar psíquico do menor e do incapaz, (...) que consiste no interesse de que obtenham um adequado processo de formação, entendido como um interesse primordial dos sujeitos individuais, e que incide antes do descobrimento e da compreensão do fenômeno da sexualidade; ou no interesse de que os menores e os incapazes tenham um desenvolvimento de personalidade livre, sem ingerências estranhas a seus interesses" ${ }^{184}$.

BITENCOURT nos crimes definidos nos artigos 218-A (Satisfação de lascívia mediante presença de criança ou adolescente ${ }^{185}$ ); 218-B (Favorecimento da prostituição ou outra forma de exploração sexual de vulnerável) ${ }^{186}$ parece não estender o conceito de violência para a situação atual das crianças e adolescentes. Salvo melhor juízo, o foco da análise do bem jurídico, que remete às considerações feitas nos artigos anteriores, está sempre na lesão ao desenvolvimento moral/sexual da criança/adolescente, e o uso do termo violência só se dá na referência violência física.

Em todos os casos, o intérprete entende que o bem jurídico protegido é, do mesmo modo como no estupro, a dignidade sexual, "a formação sexual dos menores, protegendoos especialmente contra a depravação e a luxúria, os quais não podem e não devem ser expostos, desde cedo, a essa espécie de degradação moral”,187

NUCCI e MARQUES dão um passo além, em direção a um entendimento mais integrado entre o Direito da Criança e do Adolescente e o Direito Penal. Ao comentar o artigo 218-A, apontam, a respeito do bem jurídico tutelado, que "o abuso sexual, normalmente entendido como forma de violência física, também pode se dar através da violência moral (...). O mal age, portanto, em nível psicológico, afetando a formação da sexualidade, da moral, da dignidade e de própria personalidade da vítima"188.

\footnotetext{
${ }^{184}$ GRECO e RASSI, op cit,p.75.

${ }^{185}$ BITENCOURT, op.cit. p. 113, 114.

${ }^{186}$ Idem, ibidem, p. 119-120

${ }^{187}$ Idem, ibidem, p 105.

188 NUCCI, Guilherme de Souza; MARQUES, Ivan Luís. Os contornos normativos da proteção do vulnerável prescrita pelo Código Penal (arts. 218-A e 218-B, introduzidos pela Lei 12.015/2009). Revista Brasileira de Ciências Criminais, São Paulo, v. 18, n. 86, p.9-35, set./out. 2010.
} 
Os autores remetem a estudos clínicos que comprovam as consequências do abuso sexual na infância, "razões estas mais que suficientes a justificar a tutela penal do abuso, mesmo que no plano exclusivamente psicológico". [destaquei]. Aliás, entendem os autores que a prática da conduta tipificada no artigo 218-A poderia ser praticada, inclusive, por meios virtuais, como salas de bate-papo ou sistema de videoconferência, apesar de reconhecerem ser controverso entendimento a respeito na doutrina. Há quem entenda que admitir a prática por meio virtual seria uma "exagerada interpretação extensiva" ou analogia in malam partem, proibida no Direito Penal brasileiro. Esta questão será abordada com mais profundidade logo adiante, na discussão sobre o abuso sexual on-line.

Os autores destacam, ainda, o veto presidencial ao que seria o artigo 234-C. A redação do artigo era a seguinte: “234-C: Para os fins deste Título, ocorre exploração sexual sempre que alguém é vítima dos crimes nele tipificados" ${ }^{189}$. Por sua relevância para a discussão em questão, vale trazer parte da razão do veto, citada pelos autores, que dialoga de maneira muito precisa com o acima discutido: “Ao prever que ocorrerá exploração sexual sempre que alguém for vítima dos crimes contra os costumes, o dispositivo confunde os conceitos de 'violência sexual' e de 'exploração sexual', uma vez que pode haver violência sem a exploração (...). [destaquei em itálico]

No caso específico da violência sexual mediada pela TIC, os bens jurídicos que se consideram como sendo tutelados pelas normas penais que proíbem a exposição de crianças e adolescentes à pornografia infantojuvenil na internet são considerados, em geral: o desenvolvimento normal da personalidade, da moralidade, da reserva ou inexperiência sexual dos jovens, o desenvolvimento psíquico e sexual normal ${ }^{190}$.

Segundo LANCMAN, ao se proteger crianças e adolescentes contra os riscos de violência sexual mediada pela TIC, assim, buscam-se preservar as condições básicas para que possam alcançar o livre desenvolvimento de sua personalidade, resguardando-se uma "liberdade sexual futura e potencial". ${ }^{191}$

\footnotetext{
${ }^{189} \mathrm{O}$ veto, no meu entender, foi correto, e as razões dão a exata justificativa do porquê.

${ }^{190}$ LANCMAN, Valeria A. La pornografía infantil en internet. Ciencias Penales Contemporáneas: Revista de Derecho Penal, Procesal Penal y Criminología, Mendoza, v. 3, 5/6, p.291-319, 2003. P. 299

${ }^{191}$ Idem, ibidem, p. 297.
} 
Opto por trazer, ainda, as reflexões de $\mathrm{MACHADO}^{192}$, por identificá-las como as que apresentam a leitura dogmática mais compreensiva e integradora a respeito dos crimes sexuais contra crianças e adolescentes, buscando, ainda, quando pertinente, trazer elementos de outras disciplinas para fundamentar a sua construção. Enquanto lei especial, segundo a autora, o ECA funciona como critério de interpretação de outros diplomas legais; nas suas palavras, "quando o ECA ilumina o conteúdo dos direitos fundamentais de dignidade e respeito, e, particularmente, de integridade e liberdade de crianças $\mathrm{e}$ adolescentes- que são essencialmente os bens-valores tutelados pela norma penal nos crimes que estamos analisando [crimes sexuais] - ele funciona como princípio de conformação e interpretação da lei penal ${ }^{, 193}$. [itálicos no original]

É que a CF 88 estabelece, em sua leitura, uma proibição de relativizar o conteúdo material do bem jurídico tutelado nos crimes sexuais a partir, por exemplo, da discriminação de crianças e adolescentes vítimas desses crimes a partir de qualquer tipo de critério (classe social, opção sexual, gênero, raça, etnia etc). Todos, de modo igual, têm direito à integridade, dignidade e respeito ${ }^{194}$.

Em detido exame a respeito do centro da tutela penal nos delitos sexuais contra crianças e adolescentes, a autora aponta diversos bens jurídicos lesados como decorrência das violências, levando em consideração, em sua elaboração, os direitos da personalidade infantojuvenil, a idade da vítima e as consequências do fato sexual precoce para a integridade de crianças e adolescentes e seu desenvolvimento.

A doutrina penal majoritária costuma, como se viu acima, identificar como o valor central da tutela, nos crimes sexuais, a liberdade sexual, atual (o que faria sentido até certo limite, no caso dos adolescentes) ou futura (entendimento amplamente adotado no caso das crianças). Para autora, a ficção jurídica de definir o bem jurídico na liberdade sexual futura se funda em "completo desprezo por parte da doutrina penal, dos reais contornos,

\footnotetext{
${ }^{192}$ MACHADO,. Proibições de excesso ...

${ }^{193}$ MACHADO, op cit, p.71.

${ }^{194}$ Idem, ibidem, p. 113. Este, se corretamente entendi, é um dos fundamentos da proposta da autora, citada em nota de rodapé supra, de substituir a categoria da presunção de violência pela da presunção de lesividade. A presunção de violência acaba permitindo interpretações que valoram de maneira diferente os direitos à dignidade, ao respeito e à integridade de crianças e adolescentes de diferentes classes sociais.
} 
das verdadeiras características da personalidade infantojuvenil (...)", o que leva, então, a doutrina, a crer que a lesão seria somente futura ${ }^{195}$.

O desconhecimento do que é ser criança e do que é ser adolescente (que será examinado, neste trabalho, no Capítulo a seguir), em suma, do que é estar em desenvolvimento e de como se dá este desenvolvimento, leva a um desprezo das graves lesões atuais que a prática de ato sexual de relevo (na terminologia utilizada pela autora) pode provocar à personalidade infantojuvenil. "A lesão é sempre atual, para este ser humano uno e atual (...), ainda que essa lesão efetiva também traga em seu bojo lesão diferida no tempo, sob o ângulo das potencialidades do ser humano adulto. Até por isso, a lesão atual é mais grave do que o é para o adulto". [itálicos no original]

As conclusões de WILLIAMS et all ${ }^{196}$, no âmbito da psicologia, reforçam a tese de MACHADO. Danos causados pela violência sexual contra crianças e adolescentes são classificados como reais ("prejuízos no seu desenvolvimento físico, cognitivo, emocional") ainda que a sua evidência não seja detectável, na ocasião do incidente abusivo ou quando ocorrer a negligência; os danos potenciais "referem-se à ameaça do dano que pode acontecer quando existir falta de supervisão ou proteção adequadas em um cenário perigoso ou inapropriado. (...) Estar uma ou repetidas vezes em um lugar ou situação de risco pode ter efeitos marcantes no desenvolvimento emocional ou no bem estar da criança. (...)pode ser que sequer exista o dano ainda aparente, mas quanto mais os riscos se repetirem, principalmente quando os eventos aumentarem em severidade, mais provável será que a criança ou adolescente irá sofrer danos permanentes emocionais e/ou corporais". 197

Para MACHADO, o problema da noção fictícia da liberdade sexual futura é que ela "reduz a criança e o adolescente a um 'adulto em miniatura', protegendo-os não em

\footnotetext{
195 Idem, ibidem, p. 221.

${ }^{196}$ Lúcia Cavalcanti de Albuquerque Williams é "Professora Titular do Departamento de Psicologia da Universidade Federal de São Carlos (UFSCar), coordena o LAPREV (Laboratório de Análise e Prevenção da Violência) que faz pesquisa, ensino e extensão quanto ao enfrentamento e prevenção da violência, notadamente a violência intrafamiliar e a violência na escola". (fonte: Curriculum Lattes).

${ }^{197}$ WILLIAMS; PADOVANI,; ARAÚJO; STELKO-PEREIRA; ORMEÑO; EISENSTEIN (Orgs); op cit.; p. 9 .
} 
razão da pessoa que já é; mas sim por aquilo que, no futuro, se concebe que poderia ser”, conclui ${ }^{198}$.

Assim, postula a autora, quanto mais tenra a idade da vítima, mais o centro da tutela penal se identifica com a integridade infantojuvenil e menos com a liberdade sexual. A autora identifica, nos casos de violência sexual, ao contrário de parte da doutrina, danos não só futuros, mas também atuais à personalidade infantojuvenil, danos à integridade física, psíquica e moral específica de crianças e adolescentes que, ao final, se consubstanciam em dano evidente à dignidade de crianças e adolescentes.

Dentro do conceito de integridade física, psíquica e moral específica de crianças e adolescentes encontram-se abrangidos direitos como o de brincar, de liberdade de imaginação (que faz parte de um desenvolvimento sexual saudável), entre outros, e no caso de adolescentes, em certa medida, de liberdade sexual (direito este que é atual, embora seja exercido de maneira diferente do seu exercício por adultos).

$O$ fato de que crianças e adolescentes estarem em diferentes etapas do seu desenvolvimento (inclusive, de sua sexualidade) significa, pois, que o efeito lesivo de um ato sexual praticado com uma criança ou com um adolescente, ainda que não violento, seja diferenciado. De modo que não basta levar em consideração a conduta objetiva do autor (que pode ser a mesma, praticada com uma criança ou um adolescente) pra valorá-la penalmente. Ações que, no plano realístico, configuram idêntica conduta objetiva, podem não denotar, na esfera jurídica, uma únivoca intenção lasciva, já que é preciso levar em conta "a diferença de significado que a ação tem para a vítima (...), diversa, também, porque a sexualidade da criança pequena está num plano completamente distinto daquele do adolescente (...)", mais próxima, neste caso, da sexualidade do adulto.

Com isso, fica evidente a "necessidade de diferenciar (graduar) o desvalor abstrato entre os atos sexuais não violentos passíveis de descrição pormenorizada com significado unívoco na lei penal (...), quando praticados contra criança, do desvalor abstrato dessas mesmas condutas quando praticadas contra adolescente.” [itálicos no original]

\footnotetext{
${ }^{198}$ Idem, ibidem, p. 222. Estes temas serão tratados mais amiúde na Parte II.
} 
Desse modo, a conduta do agente, mesmo que não contemple objetivamente violência real ou grave ameaça, merece, no entender da autora, a punição por parte do direito penal, devendo ser valorada de modo diverso, conforme a vítima seja criança ou adolescente $^{199}$.

Isto porque, nos crimes sexuais contra crianças e adolescentes, há dano realístico à integridade psíquica e moral ainda que não haja violência real ou grave ameaça, em razão das especificidades da personalidade infantojuvenil.

É possível, agora, tendo examinado o conceito de violência sob diferentes aspectos, chegar ao que se entende, para os fins deste trabalho, como violência sexual contra crianças e adolescentes para que, mais adiante, seja possível pormenorizar o conceito de violência sexual contra crianças e adolescentes mediada pela TIC.

A violência sexual contra crianças e adolescentes abrange diversas condutas que, antes mesmo de ser caracterizada como crime, agridem a ética, já que desnaturaliza o processo de desenvolvimento saudável de crianças e adolescentes.

A violência sexual contra crianças e adolescentes tolhe a espontaneidade, a vontade e a liberdade desses sujeitos, que deixam de exercitarem os seus direitos de ser criança e de ser adolescente, vivenciando as situações próprias de cada etapa de seus desenvolvimentos (nos tempos e espaços que, de acordo com as suas condições biológicas, psicológicas, sociais, econômicas e culturais, lhes são peculiares), para serem transformados em objetos. São violados, no ato da violência sexual, os direitos à integridade física e psicológica, ao respeito e à dignidade, ao desenvolvimento físico, psicológico, moral e sexual saudáveis.

Para se caracterizar enquanto violência sexual, um ato sexual não precisa ser necessariamente violento. $\mathrm{O}$ ato sexual, embora não violento, quando praticado contra criança ou adolescente, pode provocar tanto danos físicos, verificáveis, quanto danos realísticos à integridade psíquica e moral, não verificáveis por meio de exame físico, que serão tão maiores quando mais tenra a idade da criança/adolescente envolvida na prática, e merecerão valoração jurídico-penal igualmente proporcional.

\footnotetext{
${ }^{199}$ Idem, ibidem, p. 228.
} 
Cabe, agora, especificar brevemente as categorias abuso sexual e exploração sexual.

\title{
2.1.1.2. Abuso sexual
}

A categoria abuso sexual compreende, segundo a literatura, duas modalidades: o abuso sexual intra e extrafamiliar. Alguns conceitos de abuso sexual prendem-se mais à primeira concepção, como:

\begin{abstract}
"Todo ato ou omissão praticado por pais, parentes ou responsáveis contra crianças e/ou adolescentes que - sendo capaz de causar dano físico, sexual e/ou psicológico à vítima implica, de um lado, uma transgressão do poder/dever do adulto e, de outro lado, uma coisificação da infância"200
\end{abstract}

Na concepção de abuso sexual intrafamiliar há, ainda, uma relação com a ideia de incesto, ${ }^{201}$ embora nem todo abuso sexual intrafamiliar seja praticado entre pessoas com laços parentesco por consanguinidade, sendo comum, segundo a literatura, o abuso sexual entre padrasto e enteados/as. De todo modo, esta espécie de abuso demanda compreensão e enfrentamento bastante complexos, já que sua dinâmica, desde a configuração da relação abusiva até a denúncia, envolve inúmeros componentes conflituosos (por exemplo, a relação de cumplicidade, segredo, autoridade e culpa que se desenvolve entre a criança/adolescente e o adulto que pratica o abuso; o medo do abandono; a dificuldade da família em identificar, aceitar e denunciar o abuso; o medo da quebra da unidade familiar e até mesmo da diminuição da renda familiar, entre outros).

Um conceito mais amplo de abuso sexual seria:

"O envolvimento da criança em atividade sexual do qual ele/ela é incapaz de dar consentimento informado, ou para a qual a criança não tem preparo, em termos de desenvolvimento para dar consentimento, ou que viola as leis ou os tabus sociais de uma sociedade. $\mathrm{O}$ abuso sexual de uma criança é evidenciado

\footnotetext{
${ }^{200}$ AZEVEDO, M.A.; GUERRA, V.N.A. Pele de asno não é história - um estudo sobre a vitimização sexual de crianças e adolescentes na família. São Paulo: Rocco, 1988, p. 32 apud LIBÓRIO, Renata Maria Coimbra \& CASTRO, Bernardo Monteiro de. Abuso, exploração sexual e pedofilia: as intrincadas relações entre os conceitos e o enfrentamento da violência sexual contra crianças e adolescentes. In UNGARETTI, Maria America (org.) Criança e Adolescente: Direitos, Sexualidades e Reprodução. São Paulo: Associação Brasileira de Magistrados, Promotores de Justiça e Defensores Públicos da Infância e da Juventude ABMP; p 19-41.

${ }^{201}$ A respeito, cf COHEN, Claudio; GOBBETTI, Gisele J. Abuso sexual infrafamiliar. Revista Brasileira de Ciências Criminais, São Paulo, v. 6, n. 24, p.235-243, out./dez. 1998.
} 
por uma atividade entre uma criança e um adulto, ou entre uma criança e um adolescente que, por idade ou desenvolvimento, está em relação de responsabilidade, confiança ou poder"202.

Na conceituação acima, estende-se claramente a possibilidade de haver o abuso sexual entre um adolescente e uma criança.

O mesmo não ocorre com a definição contida no artigo 18 da Convenção do Conselho da Europa para a Proteção de Crianças contra o Abuso e a Exploração Sexual, que define o abuso sexual de crianças como:

“(a) Engajamento em atividades sexuais com uma criança que, de acordo com as disposições pertinentes do direito interno, não atingiu a idade legal para atividades sexuais;

(b) Engajamento em atividades sexuais com uma criança, em que:

- haja uso de coação, força ou ameaça;

- haja abuso de uma posição de posição manifesta de tutela, autoridade ou influência sobre a criança, inclusive dentro da família;

- haja abuso de uma situação particularmente vulnerável da criança, nomeadamente devido a uma deficiência mental ou física ou de uma situação de dependência".203

Ressalve-se que as disposições da alínea "a" não se destinam a disciplinar atividades consensuais entre crianças e adolescentes, conforme dispõe o artigo 18.3.

Por fim, há ainda definições em que se explicitam os tipos de condutas que consistem em abuso. É o caso da definição abaixo, citada por WILLIAMS:

"Situação em que uma criança ou adolescente é usada para gratificação sexual de um adulto, baseada em uma relação de

${ }^{202}$ WILLIAMS; PADOVANI,; ARAÚJO; STELKO-PEREIRA; ORMEÑO; EISENSTEIN (Orgs); op cit.; p. 7

${ }^{203}$ United Nations Children's Fund (UNICEF) Innocenti Research Centre. Child Safety Online: Global challenges and strategies Disponível em http://www.unicef-irc.org/publications/pdf/ict eng.pdf, consulta em 02/01/2012; tradução livre da autora. Criança, nos instrumentos internacionais, refere-se a criança ou adolescente (ser humano entre o zero e os 18 anos de idade). 
poder que pode incluir desde carícias, manipulação de genitália, mama ou ânus, 'voyeurismo', pornografia e exibicionismo, até o ato sexual com ou sem penetração, com ou sem utilização de violência física"204.

Valho-me aqui das observações de LOWENKRON, que refletem de modo bastante acurado os conteúdos comuns às definições usadas pela literatura e que resumem, de modo sucinto, o conteúdo das definições acima transcritas.

Segundo a antropóloga, o abuso sexual infantil é comumente definido como interações sexuais com crianças, com ênfase "na assimetria de poder (pela diferença de idade, experiência, posição social etc) e/ou no dano psicológico. Pode ser por força, promessas, ameaça, coação, manipulação emocional, enganos, pressão etc. O que é fundamental na definição do "abuso" é que o consentimento sexual da criança não é considerado válido, de modo que ela é sempre vista como "objeto" de satisfação da lascívia alheia e nunca como "sujeito" em uma relação sexual com adultos ou, dependendo do caso, mesmo com uma outra criança ou adolescente mais velhos" ${ }^{205}$. [aspas no original]

À análise desta autora, considero possível acrescentar que, salvo melhor juízo, há uma unanimidade na literatura quanto ao fato de não ser necessária a existência de violência física ou mesmo contato físico para a caracterização do abuso sexual contra crianças e adolescentes. Neste sentido, WILLIAMS et alii afirmam que: "o abuso sexual pode ter duas formas: sem contato físico (verbal, telefonemas obscenos, exibicionismo e

\footnotetext{
${ }^{204}$ MONTEIRO, L; ABREU, V.I.; PHEBO, L. B. Abuso sexual: Mitos e realidade. Petrópolis: Autores \& Agentes Associados, 1997 apud WILlIAMS, L. C. A. Introdução ao estudo do abuso sexual infantil e análise do fenômeno no município de São Carlos. In WILLIAMS, L. C. A. (Org.); ARAUJO, Eliane A C (Org.). Prevenção do abuso sexual infantil: um enfoque interdisciplinar. Curitiba: Juruá, 2009; p. 21-40; p. 22.

${ }^{205}$ LOWENKRON, Laura. Abuso sexual infantil, exploração sexual de crianças, pedofilia: diferentes nomes, diferentes problemas? Sexualidad, Salud y Sociedad Revista Latinoamericana n.5 - 2010 - pp.9-29 / ISSN 1984-6487. Disponível em http://www.epublicacoes.uerj.br/index.php/SexualidadSaludySociedad/article/viewArticle/394/804; consulta em 04.12.2010. A autora é cientista social, mestre e doutoranda em Antropologia Social pela UFRJ. No artigo em questão, analisa "como a 'violência sexual contra crianças' foi constituída, ao longo do século XX, enquanto um 'problema' com contornos próprios e marcado por uma dramaticidade específica”. Para tanto, mapeou "os processos de conceitualização e reconceitualização" da questão em várias instâncias, por meio da análise de publicações no jornal carioca "O Globo", publicações de diversos veículos de mídia na internet, além de análise de documento da OIT11 (Organização Internacional do Trabalho), "que é uma espécie de glossário da exploração sexual de crianças e adolescentes; e uma cartilha da ECPAT International12, rede global de organizações não governamentais que atuam na prevenção e no enfrentamento da prostituição infantil, da pornografia infantil e do tráfico de crianças para fins sexuais." Apesar de, por vezes, parecer carregar uma certa ironia, o uso constante que faz das aspas ao se referir aos termos, se justifica pelo fato de os seus objetos de estudo serem, justamente, os termos e os processos de constituição social dos problemas a eles associados.
} 
voyeurismo) e com contato físico (atos físico-genitais, sadismo, pornografia e prostituição)" ${ }^{\text {206 }}$.

COHEN e GOBBETTI, referindo-se especificamente ao abuso sexual intrafamiliar, em observação que pode ser estendida também ao abuso sexual extrafamiliar, afirmam que "a maioria destas relações [de abuso sexual intrafamiliar incestuosas], quando denunciadas, dificilmente obterão provas objetivas da ocorrência através de um exame de corpo de delito (...). A maioria destes relacionamentos são efetivados através de carícias e toques, não culminando em uma relação sexual completa, sendo que isto não diminui necessariamente a gravidade das consequências a seus participantes, pois não é a agressão física que define o abuso e sim a violência emocional que pode estar por trás do fato" 207 .

Pode-se dizer que violência sexual seria o termo mais genérico, seguido pela noção de abuso sexual (intra e extrafamiliar). A exploração sexual consistiria em modalidade ainda mais específica de abuso sexual. Ou seja, sempre que houver exploração sexual, haverá abuso e violência sexual. Mas nem todo o abuso se constitui, também, como exploração sexual.

O tratamento jurídico-penal para a questão do abuso sexual, no Brasil, em uma interpretação estrita, se encontra atualmente abrangido pelos seguintes tipos penais: art. 213 e $\$ 1^{\circ}$ (Estupro, no caso de vítima adolescente entre 14 e 18 anos); art. 215 (Violação sexual mediante fraude, também no caso de adolescente entre 14 e 18 anos); art 216-A e $\S$

${ }^{206}$ WILLIAMS, L. C. A.et alii, op cit p.7. DOS SANTOS, IPPOLITO E NEUMANN listam as seguintes formas de abuso sexual sem contato físico: "O assédio sexual caracteriza-se por propostas de relações sexuais. Baseia-se, na maioria das vezes, na posição de poder do agente sobre a vítima, que é chantageada e ameaçada pelo autor da agressão.

O abuso sexual verbal pode ser definido por conversas abertas sobre atividades sexuais destinadas a despertar o interesse da criança ou do adolescente ou a chocá-los (Abrapia, 2002).

Os telefonemas obscenos são também uma modalidade de abuso sexual verbal. A maioria deles é feita por adultos, especialmente do sexo masculino. Podem gerar muita ansiedade na criança, no adolescente e na família (Abrapia, 2002).

O exibicionismo é o ato de mostrar os órgãos genitais ou se masturbar diante da criança ou do adolescente ou no campo de visão deles. A experiência, contudo, pode ser assustadora para algumas crianças e adolescentes (Abrapia, 2002).

O voyeurismo é o ato de observar fixamente atos ou órgãos sexuais de outras pessoas, quando elas não desejam serem vistas e obter satisfação com essa prática. A experiência pode perturbar e assustar a criança e o adolescente (Abrapia, 2002). Nas relações sexuais entre adultos, o voyeurismo pode ser uma pratica sexual consentida. A pornografia. Essa forma de abuso pode também ser enquadrada como exploração sexual comercial, uma vez que, na maioria dos casos, o objetivo da exposição da criança ou do adolescente é a obtenção de lucro financeiro." Op cit, p. 39.

${ }^{207}$ COHEN, Claudio; GOBBETTI, Gisele J. op cit, p. 240. 
$2^{\circ}$ (Assédio sexual, no caso de adolescente entre 14 e 18 anos); art. 217-A (Estupro de vulnerável, tipo específico para crianças e para adolescentes até 14 anos de idade); art. 218-A (Satisfação de lascívia mediante presença de criança ou adolescente), todos do Código Penal. ${ }^{208}$

\subsubsection{Exploração sexual}

Como já exposto, exploração sexual de crianças e adolescentes (frequentemente referida na literatura pela sigla $\mathrm{ESCA}^{209}$ ) é uma categoria que, conforme a literatura, tem sido utilizada para abranger quatro submodalidades de violência sexual contra crianças e adolescentes: a pornografia, o turismo sexual, o tráfico para fins sexuais e a prostituição.

"Maria Lúcia Pinto Leal (2003) define a exploração sexual comercial de crianças e adolescentes como 'uma relação de mercantilização (exploração/dominação) e abuso (poder) do corpo de crianças e adolescentes (oferta) por exploradores sexuais (mercadores), organizados em redes de comercialização local e global (mercado), ou por pais ou responsáveis, e por consumidores de serviços sexuais pagos (demanda) ${ }^{\not, 210}$.

Neste tópico serão apresentadas as definições de turismo sexual, o tráfico para fins sexuais, prostituição, "pedofilia" e pornografia infantil.

A Convenção do Conselho da Europa para a Proteção de Crianças contra o Abuso e a Exploração Sexual define exploração sexual de crianças como (arts 18-23): "Prostituição infantil, pornografia infantil e participação de uma criança em espetáculos pornográficos, incluindo recrutamento, coação ou promoção da participação de uma criança em espetáculos pornográficos; lucrar com ou de qualquer outro modo explorar uma criança com tais fins e conscientemente assistir performances com a participação de crianças; promoção, de forma intencional, que uma criança que não tenha atingido a idade

\footnotetext{
${ }^{208}$ São consideradas aqui, estritamente, as condutas principais; não estão incluídas as de "facilitação" ou "indução", casos em que o legislador optou por tipificar a participação de modo autônomo, como é o caso do novo artigo 218 (Corrupção de menores). Não estão também incluídas aqui as condutas ligadas ao uso da tecnologia, previstas no ECA, que serão abordadas adiante.

${ }^{209}$ Outra forma de referência é ESCCA, sendo que o "C" extra se refere ao termo "Comercial".

${ }^{210}$ LEAL, Maria Lúcia Pinto (2003). Globalização e exploração sexual comercial de crianças e adolescentes. Rio de Janeiro, Save the Children, apud FALEIROS, Eva T. Silveira. A Exploração sexual comercial de crianças e adolescentes no mercado do sexo. In LIBÓRIO, Renata Maria Coimbra \& SOUSA, Sônia M. Gomes (organizadoras). A Exploração Sexual de Crianças e de Adolescentes no Brasil. Reflexões teóricas, relatos de pesquisas e intervenções psicossociais. São Paulo: Casa do Psicólogo. Goiânia: Universidade Católica de Goiás, 2004, p 73-98; p.75.
} 
legal para as atividades sexuais seja testemunha de abuso sexual ou de atividades sexuais, mesmo sem participação [na atividade]; e solicitação de crianças para fins sexuais"211

Nota-se que a definição é bastante ampla, abrangendo diretamente algumas das modalidades descritas, mas não especificando o turismo sexual.

A Declaração de Estocolmo, resultante do Congresso Mundial sobre Exploração Sexual de Crianças e Adolescentes, realizado em 1996 na Suécia, define a Exploração Sexual Comercial de Crianças como uma violação fundamental de seus direitos, compreendendo "o abuso sexual por um adulto e a remuneração em dinheiro ou espécie para a criança ou para outrem. A criança é tratada como um objeto sexual e comercial. A exploração sexual comercial de crianças constitui-se em uma forma de coerção e violência contra as crianças, podendo implicar em trabalho forçado e formas contemporâneas de escravidão" 212 .

Há, ainda, definições que incluem os casamentos forçados de crianças como uma forma de exploração sexual. É o caso da ECPAT $^{213}$ que, citada por LIBÓRIO E CASTRO, incorpora alguns elementos da Declaração de Estocolmo e, por ocasião do II Congresso Mundial contra a Exploração Sexual de Crianças e Adolescentes, realizado em Yokohama/Japão, em 2001, incluiu na definição de ESCA a explícita menção ao turismo sexual e ao casamento forçado de crianças, e salientou a importância de considerar as transações em espécie na compreensão do problema. Aí se incluem, por exemplo, casos em que a exploração sexual ocorre em troca da proteção, ou de um lugar para dormir.

\footnotetext{
${ }^{211}$ United Nations Children's Fund (UNICEF) Innocenti Research Centre. Child Safety Online: Global challenges and strategies Disponível em http://www.unicef-irc.org/publications/pdf/ict_eng.pdf, consulta em 02/01/2012; tradução livre da autora.

${ }^{212}$ Declaration and Agenda for Action; 1st World Congress against Commercial Sexual Exploitation of Children. Stockholm, Sweden, $27 \quad-\quad 31 \quad$ August. Disponível em http://www.csecworldcongress.org/PDF/en/Stockholm/Outome_documents/Stockholm\%20Declaration\%20 1996_EN.pdf, consulta em 05/01/2012. Tradução livre da autora.

213 "ECPAT International é uma rede global de organizações e indivíduos que trabalham juntos para a eliminação da prostituição infantil, pornografia infantil e tráfico de crianças para fins sexuais. Procura incentivar a comunidade mundial para assegurar que todas as crianças usufruam dos seus direitos fundamentais livres e seguras de todas as formas de exploração sexual comercial". Fonte: http://www.ecpat.net/ei/Ecpat_vision.asp, tradução livre da autora, acesso em 05/01/2012. A sigla ECPAT quer dizer "End child prostitution, child pornography, and the trafficking of children for sexual purposes", em português, "fim à prostituição infantil, pornografia infantil e ao tráfico de crianças para fins sexuais".
} 
Esta definição salienta também a diferenciação da exploração sexual e do abuso sexual, deixando claro que a exploração também uma forma de abuso, mas que, neste caso, o ganho comercial é ausente.

No documento final do III Congresso Mundial, realizado no Rio de Janeiro em 2008 ("Declaração do Rio de Janeiro"), o termo exploração sexual de crianças e adolescentes foi utilizado para denotar "todas as formas de abuso sexual e exploração de pessoas com menos de 18 anos em todas as situações: no lar e na família, nas escolas e instituições educacionais, em abrigos e instituições de justiça, na comunidade e no local de trabalho. ${ }^{214,}$ Ou seja, o termo exploração sexual, nesse documento, inclui o abuso sexual intra e extrafamiliar, situações que não envolvem a relação de comercialização, conforme se viu acima. Isto parece ser um retrocesso considerando a dificuldade, identificada pela literatura, em sistematizar os conceitos, e os esforços que vêm sendo feitos ao longo dos últimos anos neste sentido.

A Declaração do Rio de Janeiro acrescentou ainda mais um elemento à questão da exploração sexual, que diz respeito diretamente ao tema deste trabalho, quando os signatários expressam a sua preocupação com "o aumento de determinadas formas de exploração sexual de crianças e adolescentes, em particular o abuso por meio da Internet e de tecnologias novas e em desenvolvimento, e como resultado da crescente mobilidade de violadores em viagens e no turismo." 215.

Novamente valho-me da sistematização feita por LOWENKRON ${ }^{216}$ a partir da análise da literatura para destacar os pontos comuns às definições acima apresentadas:

Segundo a autora, a categoria exploração sexual, definida enquanto conceito distinto em relação à noção de abuso, "se refere menos a atos isolados ou interações sexuais interpessoais do que a redes de pessoas e condutas. Em geral, aparece associada à ideia de "exploração comercial" e ao chamado "crime organizado". Nesse contexto, a criança é concebida como sendo transformada não apenas em "objeto", mas em "mercadoria"”.

\footnotetext{
${ }^{214}$ Anais do III Congresso Mundial..., p. 65, nota de rodapé.

${ }^{215}$ Idem, ibidem.

${ }^{216}$ LOWENKRON, Laura, op cit., p n/d.
} 
A exploração sexual comercial, continua a autora, "é entendida como um fenômeno complexo que articula diversos agentes, como aliciadores (inclusive familiares), "clientes", “exploradores", estabelecimentos comerciais, agências de viagens, hotéis, bares, boates etc. Inclui as seguintes modalidades: prostituição infantil, tráfico para comércio sexual, turismo sexual infantil e pornografia infantil. A ênfase é na vulnerabilidade das vítimas e na necessidade de sua proteção, sendo fortemente associada à ideia de vulnerabilidade social, articulado ao problema da "miséria", das "famílias desestruturadas", das "drogas" etc". [aspas no original]

Os tipos penais ligados à exploração sexual serão indicados abaixo, junto com a apresentação das formas específicas de exploração sexual.

\section{a) Turismo Sexual}

O turismo sexual é uma das modalidades de exploração sexual. "É o comércio sexual, em cidades turísticas, envolvendo turistas nacionais e estrangeiros e principalmente mulheres jovens, de setores pobres e excluídos" ${ }^{217}$ em países em desenvolvimento. O principal serviço sexual oferecido é a prostituição, mas também há comercialização de pornografia (shows eróticos).

Segundo DOS SANTOS, IPPOLITO e NEUMANN, o turismo sexual "caracterizase, por um lado, pela organização de "excursões" turísticas, com fins não declarados de proporcionar prazer sexual a turistas estrangeiros ou de outras regiões do país e, por outro lado, pelo agenciamento de crianças e adolescentes para oferta de serviços sexuais". Segundo os autores, no final da década dos 1980 e na década dos 1990, em cidades como Recife, Fortaleza, Natal e Salvador, certas agências de turismo, facilitavam o aliciamento de meninas para trabalharem no mercado do sexo, chegando a oferecer álbuns fotográficos de meninas para serem oferecidas aos turistas ${ }^{218}$.

O turismo sexual tem uma relação íntima com o tráfico de pessoas para fins sexuais (é a compra e venda de crianças que, muitas vezes, fornece a "mão-de-obra" que

\footnotetext{
${ }^{217}$ FALEIROS, Eva T. Silveira. A Exploração sexual comercial de crianças e adolescentes no mercado do sexo... p.79.

${ }^{218}$ DOS SANTOS; IPPOLITO; NEUMANN, op cit, p. 91.
} 
será explorada sexualmente no turismo sexual) e com a prostituição (um dos "serviços" oferecidos).

Salvo melhor juízo, não há no Brasil um tipo penal específico relacionado à conduta de utilizar-se de rede de turismo sexual, podendo as condutas já tipificadas na legislação (como as acima mencionadas de estupro, estupro de vulnerável etc) serem aplicáveis aos autores de violência sexual conforme a situação concreta.

No caso dos donos de locais onde se exploram sexualmente crianças/adolescentes, aliciadores, agenciadores ou outros participantes da rede de turismo sexual, há também condutas tipificadas no CP e no ECA que serão apresentadas nos tópicos a seguir.

\section{b) Tráfico para fins de exploração sexual}

O tráfico de crianças e adolescentes para fins de exploração sexual "é uma das modalidades mais perversas de exploração sexual. A prática envolve atividades de cooptação e/ou aliciamento, rapto, intercâmbio, transferência e hospedagem da pessoa recrutada para essa finalidade. Todavia, o mais recorrente é que o tráfico para fins de exploração sexual de crianças e adolescentes ocorra de forma "maquiada" por agências de modelo, turismo, trabalho internacional, namoro-matrimônio e, mais raramente, por agências de adoção internacional. Muitas jovens, seduzidas por uma rápida mudança de vida ou sucesso fácil, embarcam para outros estados do país ou para outros países e lá se vêem forçadas a entrar no mercado da exploração sexual"219.

O tráfico de crianças/adolescentes pode envolver diversas atividades, não sendo necessário que haja, necessariamente, elementos de venda stricto sensu durante o processo. As atividades que caracterizaram a venda são: recrutamento (venda da criança a um traficante pelos pais ou outros responsáveis pelo seu cuidado, ou por uma instituição); transporte, transferência e acolhimento (durante a circulação da criança, esta pode ser vendida por um traficante a outro); recepção (a criança pode ser vendida pelo traficante a 
um “comprador" final) e exploração: a criança pode, em qualquer momento, ser vendida a outro traficante ou explorador ${ }^{220}$.

Porém, a venda de crianças não constitui um elemento necessário da definição de tráfico de crianças, de modo que o recrutamento, por exemplo, pode ter lugar mediante fraude, uso da força ou rapto; não é necessário, ainda, que haja uma transação comercial ou qualquer eventual "remuneração ou outra retribuição" quando a criança é transferida de um traficante para outro. A circulação, portanto, mais que a venda, é um elemento essencial para a caracterização do tráfico. "A retirada de uma pessoa do seu ambiente social constitui um elemento fundamental do conceito de tráfico, dado que aumenta a vulnerabilidade da vítima.”

CASTELLS, no capítulo anterior, indicava a estreita relação entre o tráfico para fins de exploração sexual e a globalização. Este fenômeno "emerge inserido numa economia clandestina e ilegal, organizada em redes locais e transnacionais, estruturadas em mecanismos que viabilizam o recrutamento e o aliciamento de mulheres, crianças e adolescentes, reforçando a dependência social, econômica e psicossocial desses segmentos. $^{221}$.

A conduta de tráfico de pessoas para fins de exploração sexual foi tipificada nos artigos $231^{222}$ e 231-A ${ }^{223}$ do Código Penal, nas modalidades de tráfico internacional e

\footnotetext{
${ }^{220}$ Segundo o artigo $2^{\circ}$, a) do Protocolo Facultativo à Convenção sobre os Direitos da Criança relativo à venda de crianças, prostituição e pornografia infantis", venda de crianças é "qualquer acto ou transacção pelo qual uma criança é transferida por qualquer pessoa ou grupo de pessoas para outra pessoa ou grupo contra remuneração ou qualquer outra retribuição" (Disponível em http://www.unicef.pt/docs/pdf/protocolo_facultativo_venda_de_criancas.pdf); O Protocolo Adicional Relativo à Prevenção, Repressão e Punição do Tráfico de Pessoas, em Especial Mulheres e Crianças (conhecido como Protocolo de Palermo, aprovado em 2000), define a expressão "tráfico de pessoas" como: "o recrutamento, o transporte, a transferência, o alojamento ou o acolhimento de pessoas, recorrendo à ameaça ou ao uso da força ou a outras formas de coação, ao rapto, à fraude, ao engano, ao abuso de autoridade, à situação de vulnerabilidade ou à entrega ou aceitação de pagamentos ou benefícios para obter consentimento de uma pessoa que tenha autoridade sobre outra para fins de exploração". ORGANIZAÇÃO DAS NAÇÕES UNIDAS. Protocolo Facultativo à Convenção sobre os Direitos da Criança relativo à venda de crianças, prostituição e pornografia infantis. Disponível em http://www.unicef.pt/docs/pdf/protocolo_facultativo_venda_de_criancas.pdf, consulta em 14.11.2011. Adotado em Nova York em 25 de maio de 2000, o Congresso Nacional aprovou o texto por meio do Decreto Legislativo $n^{\circ} 230$, de 29 de maio de 2003, o Governo brasileiro depositou o instrumento de ratificação junto à Secretaria-Geral da ONU em 27 de janeiro de 2004; e a Presidência da República promulgou o Protocolo por meio do Decreto ${ }^{\circ}$ 5.007, de 8 de março de 2004.

${ }^{221}$ DOS SANTOS; IPPOLITO; NEUMANN, op cit, p.89-91.

${ }^{222}$ Tráfico internacional de pessoa para fim de exploração sexual.

Art. 231. Promover ou facilitar a entrada, no território nacional, de alguém que nele venha a exercer a prostituição ou outra forma de exploração sexual, ou a saída de alguém que vá exercê-la no estrangeiro. (...)
} 
nacional (interno). A redação dos artigos é bastante similar, havendo previsão de causa de aumento de pena se a vítima for criança/adolescente ou se houver sido praticado por meio de fraude, violência ou grave ameaça (em ambos os artigos, § $2^{\circ}$, I e IV). Essas disposições indicam não só a maior gravidade do fato praticado contra criança e adolescente, mas também que o consentimento da vítima é desconsiderado para a configuração da conduta típica; ou seja, mesmo que a vítima (adulta, criança ou adolescente) saiba exatamente o que a espera no local de destino, persiste o crime.

Do mesmo modo que na norma internacional, o CP não exige a venda e compra para que se considere a conduta como tráfico, o que se depreende da previsão das condutas de venda, agenciamento, aliciamento ou compra ou transporte como equiparadas ao tráfico $\left(\S 1^{\circ}\right)$.

Chama a atenção também a causa de aumento de pena, prevista no já mencionado $\S 2^{\circ}$, para agentes que tenham relação de parentesco com a vítima ou tenham assumido, por lei ou outra forma, obrigação de cuidado, proteção ou vigilância. É comum a entrega de crianças em troca de dinheiro ou de bens pelos próprios pais, que acontece especialmente em locais ou situação de miserabilidade.

\section{c) Prostituição Infantil ou Exploração Sexual Comercial}

$\S 1^{\underline{0}}$ Incorre na mesma pena aquele que agenciar, aliciar ou comprar a pessoa traficada, assim como, tendo conhecimento dessa condição, transportá-la, transferi-la ou alojá-la.

$\S 2^{-}$A pena é aumentada da metade se:

I - a vítima é menor de 18 (dezoito) anos; (...)

III - se o agente é ascendente, padrasto, madrasta, irmão, enteado, cônjuge, companheiro, tutor ou curador, preceptor ou empregador da vítima, ou se assumiu, por lei ou outra forma, obrigação de cuidado, proteção ou vigilância; ou

IV - há emprego de violência, grave ameaça ou fraude.

(Artigo e parágrafos com redação dada pela Lei no 12.015 , de 2009).

${ }^{223}$ Tráfico interno de pessoa para fim de exploração sexual

Art. 231-A. Promover ou facilitar o deslocamento de alguém dentro do território nacional para o exercício da prostituição ou outra forma de exploração sexual: (...)

$\S 1^{\circ}$ Incorre na mesma pena aquele que agenciar, aliciar, vender ou comprar a pessoa traficada, assim como, tendo conhecimento dessa condição, transportá-la, transferi-la ou alojá-la.

$\S 2^{\underline{o}}$ A pena é aumentada da metade se:

I - a vítima é menor de 18 (dezoito) anos; (...)

III - se o agente é ascendente, padrasto, madrasta, irmão, enteado, cônjuge, companheiro, tutor ou curador, preceptor ou empregador da vítima, ou se assumiu, por lei ou outra forma, obrigação de cuidado, proteção ou vigilância; ou IV - há emprego de violência, grave ameaça ou fraude. (...)

(artigo e parágrafos com redação dada pela Lei $n^{\circ} 12.015$, de 2009) 
O Protocolo Facultativo à Convenção sobre os Direitos da Criança relativo à venda de crianças, prostituição e pornografia infantis, define a prostituição infantil como o uso de uma criança em atividades sexuais em troca de remuneração ou de qualquer outra forma de consideração" (artigo 2, b).

O uso do termo prostituição é questionado por profissionais e estudiosos da infância e juventude por considerarem que ela não representa uma opção, uma escolha de crianças e adolescentes, mas sim uma situação a que são induzidos por adultos. Outros termos, como ou crianças prostituídas ou crianças abusadas/exploradas sexualmente, são preferidos, buscando-se "enfatizar a condição passiva das crianças ou adolescentes que se envolvem nessas atividades, diferenciando-a, radicalmente, da prostituição e pornografia adultas, ao negar qualquer dimensão de escolha. O objetivo é se opor à visão, classificada pelos militantes dos direitos da criança como "tradicional" e "conservadora", que responsabiliza a criança e, principalmente, a adolescente, a partir da uma acusação moral de "promiscuidade", assumindo como voluntária a condição de prostituição das jovens". ${ }^{224}$

DOS SANTOS, IPPOLITO e NEUMAN preferem o uso dos termos trabalho sexual infantojuvenil agenciado ou autônomo para fazer referência às situações de crianças e adolescentes que vendem sexo com ou sem intermediação de pessoas. A distinção revela um questionamento com relação à autonomia, em especial dos adolescentes envolvidos no trabalho sexual autônomo. Segundo os autores, o trabalho sexual autônomo pode ser a principal estratégia de sobrevivência de adolescentes, que lhes permite custear o vício em drogas ou ter um estilo de vida desejado ${ }^{225}$.

No caso do trabalho sexual infantojuvenil agenciado, segundo os mesmos autores, crianças e adolescentes podem chegar à situação de semiescravidão ${ }^{226}$.

\footnotetext{
${ }^{224}$ LOWENKRON, op. cit. p. n/d.

${ }^{225}$ Para uma visão crítica a respeito do trabalho sexual adolescente, cf. DOS SANTOS, Benedito Rodrigues; ARAÚJO, Rogério. O enfrentamento da exploração sexual infantojuvenil: metodologia de trabalho e intervenção. Goiânia: Cânone Editorial, 2009; p. 25. O trabalho é mencionado na Parte II desta pesquisa. A visão de DOS SANTOS e ARAÚJO, embora considere que parte dos adolescentes inicia e mantém-se no trabalho sexual por escolha própria, não vem eivada do julgamento moral que, segundo LOWENKRON, costuma acompanhar a tradicional atribuição de responsabilidade às adolescentes envolvidas na prostituição. ${ }^{226}$ Trabalho sexual infanto-juvenil agenciado "é a venda de sexo intermediada por uma ou mais pessoas ou serviços. No primeiro caso, essas pessoas são chamadas rufiões, cafetões e cafetinas e, no segundo, os serviços são normalmente conhecidos como bordéis, serviços de acompanhamento, clubes noturnos. Os trabalhadores sexuais pagam a essas pessoas ou serviços um percentual do que ganham em troca de residência, pensão alimentar, roupas, transporte, maquiagem e proteção durante a realização do trabalho. Em
} 
A atividade de prostituição infantojuvenil agenciada ou autônoma pode incluir não só o pagamento em dinheiro, mas também a venda de sexo para a satisfação de necessidades básicas (alimentação, vestuário, abrigo) ou o acesso ao consumo de bens e de serviços; estas atividades estão fortemente vinculadas ao turismo sexual e, em parte dos casos, também, ao tráfico nacional e internacional de crianças e adolescentes para fins de exploração sexual.

A lei brasileira pune a exploração sexual de crianças e adolescentes em um tipo específico (Art. 244-A do $\mathrm{ECA}^{227}$ ), responsabilizando, ainda, além do agenciador (rufião ou cafetão) o proprietário, gerente ou responsável pelo local onde se realizam os encontros. O tipo não define prostituição ou exploração sexual. As condutas dos "clientes", por seu turno, são punidas, especialmente, conforme os artigos do capítulo I (Dos Crimes Contra a Liberdade Sexual), Título VI (Dos Crimes Contra a Dignidade Sexual), do Código Penal.

\section{d) Pedofilia}

Pode-se dizer sem medo que o uso dos termos "pedofilia" e "pedófilo" está disseminado na sociedade atual (não só na brasileira, aliás), sendo largamente utilizado para designar aqueles ("pedófilos") que seriam a "encarnação do mal" (a "pedofilia"). Debaixo do termo guarda-chuva "pedofilia", conforme este uso disseminado, abrigam-se diversos tipos de condutas contra crianças e adolescentes, inclusive a violência sexual, e seus respectivos atores (alguns deles já apresentados acima).

No entanto, os pesquisadores da temática da violência sexual contra crianças e adolescentes advogam por um uso bem mais restrito do termo pedofilia. LOWENKRON $^{228}$ resume uma descrição que é comum aos artigos e pesquisas consultados para a elaboração deste trabalho: "a "pedofilia" é, originalmente, uma categoria clínica da psiquiatria, definida como uma modalidade de "perversão sexual". De acordo com o DSM

alguns casos, há relação amorosa e sexual entre a trabalhadora e o agenciador, particularmente entre garotas de programas e cafetões (ou gigolôs). Todavia, o que normalmente acontece, nesses casos, é que os profissionais do sexo se transformam em reféns de seus agenciadores, caracterizando uma relação de exploração ou de semi-escravidão".

${ }^{227}$ Art 244-A. Submeter criança ou adolescente, como tais definidos no caput do art. $2^{2}$ desta Lei, à prostituição ou à exploração sexual:(...)

$\S 1^{\mathrm{o}}$ Incorrem nas mesmas penas o proprietário, o gerente ou o responsável pelo local em que se verifique a submissão de criança ou adolescente às práticas referidas no caput deste artigo.

${ }^{228}$ LOWENKRON. op cit, p. n/d. 
IV-TR19, a "pedofilia" é hoje classificada como uma modalidade de "parafilia", caracterizada pelo foco do interesse sexual em crianças pré-púberes (geralmente, com 13 anos ou menos) por parte de indivíduos com 16 anos ou mais e que sejam ao menos cinco anos mais velhos que a criança, ao longo de um período mínimo de seis meses. O diagnóstico de pedofilia pode ser feito, segundo o manual, se a pessoa realizou esses desejos ou se os desejos ou fantasias sexuais causaram acentuado sofrimento ou dificuldades interpessoais".

Apesar disso, como indicado acima, a autora aponta a utilização do termo, no debate público, não apenas para definir este estado psicológico, mas para definir uma "categoria social que se refere tanto a atos sexuais com crianças (principalmente, quando esses atos envolvem famosos, estrangeiros ou pessoas de status social elevado), quanto ao fenômeno da "pornografia infantil na internet"”".

Para além disso, não parece haver uma compreensão da diferença entre as condutas dos autores de violência sexual contra crianças e adolescentes (que pode ou não ser um "pedófilo") e as condutas dos demais atores envolvidos nas atividades de exploração sexual de crianças e adolescentes, como agenciadores, aliciadores, facilitadores, etc.

LOWENKRON frisa, ainda, com razão, que o uso do termo pedofilia enfatiza a associação entre crime e doença (como, aliás, se depreende da própria aceitação, praticamente unânime, da definição da pedofilia a partir do DSM IV-TR19, acima mencionada). Tal associação enfatiza as "características psicológicas (anormalidade e perversidade) do adulto que se relaciona sexualmente com crianças ou daquele que produz, divulga ou consome imagens de pornografia infantojuvenil". Com o foco da atenção no "pedófilo", alimenta-se o "sentimento de horror e de repulsa que faz com que apareça a figura do "monstro", sobre a qual a atenção pública vai se concentrar."

LANDINI $^{229}$ aponta que a associação entre crime e doença, no caso da pedofilia, pode ser uma decorrência do fato de que o "perfil estereotipado de um pedófilo", segundo a mídia impressa, é o do "estrangeiro, rico, pertencente a uma rede de pedofilia, que troca fotos de pornografia de crianças desconhecidas. Mas o que faria alguém com essas

\footnotetext{
${ }^{229}$ Tatiana Savoia LANDINI é pesquisadora e professora da UNIFESP e se dedica a pesquisar a temática da pornografia infantil e da exploração sexual de crianças e adolescentes desde a década de 1990.
} 
características, rico, provavelmente um europeu, tomar parte em algo sórdido como esse? A resposta é simples, ele é um doente mental, deve ter sofrido algum trauma na infância."230

Apesar da possibilidade de se questionar o uso do termo "pedofilia" a partir de sua definição médica, já que ele resulta, como se vê, na associação crime-doença (com as consequências que desta associação decorrem, como a polêmica proposta de castração química como pena para "pedófilos" condenados), ainda assim é preferível manter o uso do termo reservado ao campo médico-psicológico e às situações específicas em que haja o seu diagnóstico; mais ainda, é preciso evitar a sua inserção nas leis penais.

O grande risco de permitir que o termo "pedofilia" seja inserido na lei penal é perpetuar de uma vez o uso errôneo do termo e todos os estereótipos que o acompanham, com as nefastas consequências para os seus portadores. $\mathrm{O}$ condenado por um crime de "pedofilia" carregará, para o resto de sua vida, a "letra escarlate", o estigma que o identifica como anormal e que impede qualquer tipo de reinserção social, uma vez cumprida sua pena ou tendo optado por uma "alternativa" como a castração química.

Ademais, nada indica, atualmente, que os profissionais que atuam no Sistema de Justiça Criminal, dos policiais até os "operadores do Direito" (juízes, promotores, advogados), não carreguem consigo, para os fóruns e delegacias, esse mesmo sentimento misto de rancor e temor contra o "pedófilo" que é propagandeado pela mídia e capitalizado por legisladores atrás do apoio popular.

A tipificação de um "crime de pedofilia" (praticado, evidentemente, por um "pedófilo") criaria, além disso, uma situação que é abominada por qualquer estudioso das ciências criminais (e também da psicologia, da psiquiatria, das ciências sociais etc) que prezem os princípios básicos dos Estados Democráticos de Direito e de um Direito Penal Mínimo e garantista: a volta escancarada ao direito penal do autor, punindo-se o indivíduo pelo que ele é ("pedófilo"), ao invés de puni-lo por sua conduta.

${ }^{230}$ LANDINI, Tatiana Savoia. Pedófilo, quem és? A pedofilia na mídia impressa. Cadernos de Saúde Pública (FIOCRUZ), Rio de Janeiro, v. 19, n. supl. 2, p. S273-S282, 2003. Disponível em http://www.scielo.br/pdf/csp/v19s2/a09v19s2.pdf ; p. 281. 
O Relatório da "CPI da Pedofilia na Internet" ${ }^{231}$, realizada pelo Senado Federal, como o próprio título indica, contém incontáveis menções a esses termos, impregnadas das concepções deterministas e abjetas do direito penal do autor. E menções claras à intenção de incluir os termos na lei, proferidas por operadores do direito. Destaco, para exemplificar, alguns trechos do Relatório da CPI:

\begin{abstract}
"Então o Senador Magno Malta [presidente da CPI] diz que a intenção é tipificar o crime de pedofilia classificado como contato sexual envolvendo adultos e crianças, com elevação de sua pena para 30 anos de reclusão" (depoimento de Rinaldo Aparecido Barros, Juiz de Direito da Comarca de Niquelândia/GO, p. 402)
\end{abstract}

"Então, aqui foi criado: 1) um tipo penal autônomo para criminalizar a venda de material pedófilo" (Senador Demóstenes Torres $^{232}$, p. 364)

Na seção 2.5.2 do Relatório há um detalhado registro de um debate, que se deu por email, a respeito do uso do termo "pedofilia" como nomen juris no Projeto de Lei do Senado (PLS) n 177/2009), que pretendia alterar o Código Penal.

Esta discussão envolveu profissionais de diversas disciplinas e instituições (que prestaram assessoria aos Senadores durante o período em que a CPI desenvolveu suas atividades) e os Senadores membros da Comissão. Novamente, destaco alguns trechos para exemplificar:

"Sobre a PL do CP, volto a insistir na colocação do termo 'pedofilia mediante estupro' e 'pedofilia mediante atentado violento ao pudor'.

(...) Ser pedófilo, (...) não é crime por si só, mas uma característica da pessoa (preferência sexual). Praticar a pedofilia mediante estupro, atentado violento ao pudor, pornografia infantil, etc. é que configura o crime!!

(...) Dentro do mesmo raciocínio, (...) entendo que a expressão correta é "pedófilo criminoso", (...) porque a pedofilia só passa

\footnotetext{
${ }^{231}$ BRASIL. SENADO FEDERAL: CPI da Pedofilia na Internet. Relatório final. Brasília: Senado Federal, 2010 .

${ }^{232}$ Relator da CPI, o Senador Demóstenes Torres é Procurador da República e, portanto, bacharel em Direito. Isso não impediu que utilizasse os termos "pedófilo" e "pedofilia" incontáveis vezes, conforme os registros da $\mathrm{CPI}$.
} 
a ser crime quando praticada mediante estupro, atentado violento ao pudor, pornografia infantil, etc.

(...) o vocábulo pedofilia já é amplamente usado pela população, pelos meios de comunicação e pelos parlamentares exatamente para indicar o estupro e o atentado violento ao pudor cometidos contra uma criança (não uma doença ${ }^{233}$.

A intenção do nomen juris é facilitar o entendimento, e, neste caso, também serve para caracterizar a intenção desta CPI e definir o criminoso que comete atos tão hediondos (...) como 'pedófilo' - condenado por pedofilia - não porque seja necessariamente um doente, mas porque é um criminoso que revela grande periculosidade (...)

Trata-se de tipificar a conduta de pedofilia (a ação), não o portador da parafilia (...) Aquele que pratica o ato de pedofilia é criminoso, independentemente de sua condição psicológica" ${ }^{234}$.

(Carlos José e Silva Fortes, Promotor de Justiça de Minas Gerais, p. 457-460; 470-472)

"Bom, pelo que entendi, queremos prever alguma punição para a 'pedofilia' na Lei.

Diante disto, poderíamos prever que uma vez comprovada a Pedofilia (laudo médico) e a prática de crimes sexuais contra crianças e adolescentes (...), alguma sanção seria aplicada ao criminoso em razão desta 'doença'. (...) propor a aplicação de medida de segurança se em razão do grau da doença for causa de internação e não de prisão, e obrigação de tratamento psiquiátrico durante o período da prisão (...).

Podemos até propor um regime especial para pedófilos." (Carlos Eduardo Miguel Sobral, Delegado da Polícia Federal, p. 460).

“(...) eu acho que é importante manter a definição 'Pedofilia em Estupro' (...). Tenho visitado algumas faculdades e todos cobram o termo 'pedofilia' no Código Penal". (Karla Dias Sandoval, Procuradora de Justiça do Espírito Santo, p. 472)

Optei, propositadamente, por chamar a atenção para os registros favoráveis à inclusão do termo "pedofilia", sendo necessário reconhecer, porém, que outros operadores do Direito consultados manifestaram-se contrariamente à inclusão do termo, posição que

\footnotetext{
${ }^{233}$ Nesta passagem, nota-se que não há qualquer reflexão a respeito da possibilidade de o estupro de uma criança ser praticado por alguém que não seja "portador" de "pedofilia".

${ }^{234}$ Há uma clara tentativa (mal sucedida) de transformar o argumento, inclinado ao estabelecimento de um delito de autor, em um argumento a favor do direito penal do fato.
} 
acabou sendo vencedora (notadamente, André Estevão Ubaldino Pereira, Procurador de Justiça de Minas Gerais; Thiago Nunes de Oliveira Tavares, representante da [ONG] Safernet Brasil; Rogério de Melo Gonçalves, Consultor Legislativo do Senado Federal; Priscila Costa Schreiner, Procuradora da República em São Paulo; Ana Lúcia Melo, Promotora de Justiça do Rio de Janeiro; Stenio Santos Sousa, Delegado de Polícia Federal).

O relatório da CPI registra, porém, que aqueles que eram favoráveis à inclusão do termo só foram "convencidos" da sua inadequação quando, em 30/01/2009, uma notícia foi publicada no site globo.com informando que um homem de 43 havia sido linchado, acusado de seguir uma menina de 8 anos. A notícia relata que, identificado por populares, "em vez de telefonarem para a Polícia Militar, algumas pessoas se reuniram para o linchar" (sic) $)^{235}$.

O último email do grupo, enviado pelo Procurador André Estevão, deixa claro que havia insistência por parte do Presidente da CPI, Senador Magno Malta, na inclusão do termo pedofilia na lei penal: "Sei que o Senador Presidente insiste na tese. Nossos compromissos de consciência nos obrigam, todavia, a empregar (...) todos os esforços para convencê-lo do contrário. ${ }^{236}$

Não é leviano supor, porém, que se consultados, provavelmente a maior parte dos operadores do Direito do Brasil concordaria em incluir o termo "pedofilia" como nomen juris dos crimes de estupro contra criança/adolescente, já que, como asseverava a Procuradora Karla Dias Sandoval, “todos cobram o termo 'pedofilia' no Código Penal”.

A "pedofilia", portanto, não é um tipo penal autônomo no Direito Penal brasileiro, já que tal previsão ofenderia aos mais basilares princípios do direito penal, criando gritante situação de direito penal do autor.

O material constante do Relatório da CPI da Pedofilia é extremamente rico e daria ensejo a inúmeras análises, que não são possíveis no âmbito deste trabalho ${ }^{237}$.

\footnotetext{
${ }^{235}$ BRASIL. SENADO FEDERAL, op cit, p. 479.

${ }^{236}$ Idem, p. 481

${ }^{237}$ O trabalho de análise das sessões da CPI, do Relatório e do acompanhamento da equipe da Polícia Federal especializada em crimes de pornografia infantil (GECOP - Grupo Especial de Combate aos Crimes
} 
Aponta-se, porém, que os trechos destacados indicam uma forte tendência de associação entre crime e doença nos casos de violência sexual contra crianças e adolescentes por parte dos setores sociais, aqui representados por uma parcela dos operadores do direito e pelos membros do Senado Federal, que reverberam a fala da população em geral e da mídia (como indicam os próprios depoentes, e que é confirmado pelas pesquisas de LOWENKRON e LANDINI, dentre outros).

Se tal constatação não causa surpresa, causa, por outro lado, preocupação. Essas concepções refletem a ideologia do positivismo cientificista que ganhou força a partir do final do século XIX e ainda persiste, embora tenha perdido a primazia nos meios acadêmicos. Para os positivistas, “o infrator era um prisioneiro de sua própria patologia (determinismo biológico) (...). Ele era um escravo de sua carga hereditária: um animal selvagem e perigoso (...)"238.

E "se a conduta criminosa se deve a causas biopsicológicas, isto é, a causas intrínsecas ao indivíduo (...) conclui-se que entre delinquentes e não delinquentes existe uma linha demarcatória (...) [que somente poderia ser superada] através da 'cura', da recuperação ou, que seja, da ressocialização. Ou seja, os delinquentes passam a ser indivíduos estranhos ao mundo dos não delinquentes (...) [concepção esta que decorre] da concepção causalista da conduta criminosa e do conceito de periculosidade"239.

Esta discussão ganha relevância no âmbito deste trabalho quando se considera que medidas de prevenção vitimal ancoradas em uma perspectiva Criminológica e Vitimológica de Direitos Humanos não podem alimentar esses estereótipos já largamente difundidos pela mídia e espalhados pela sociedade. Ao contrário, no âmbito dos programas/projetos etc, deve-se promover a discussão aberta e franca a respeito destas

de Ódio e Pornografia Infantil na Internet) se constitui no campo de análise de LOWENKRON em sua tese de Doutorado (que, salvo engano, ainda se encontrava em andamento no momento da conclusão desta). Alguns dos conteúdos do Relatório já constavam, porém, no artigo da autora já mencionado.

${ }^{238}$ SHECAIRA, Sérgio Salomão. Criminologia. $2^{\mathrm{a}}$ ed. São Paulo: Editora Revista dos Tribunais, $2009 ; \mathrm{p}$. 52.

${ }^{239}$ SÁ, Alvino Augusto de. Criminologia Clínica e Execução Penal: Proposta de um modelo de Terceira Geração. Revista dos Tribunais. 2011; p. 137. 
questões, problematizando as visões estereotipadas, de forma adequada (conforme os sujeitos envolvidos no trabalho) $)^{240}$.

\section{e) Pornografia infantil.}

O conceito de pornografia infantil mais utilizado até o momento, reproduzido na literatura consultada, é o constante do Protocolo Facultativo à Convenção sobre os Direitos da Criança relativo à venda de crianças, prostituição e pornografia infantis. ${ }^{241}$

O documento define pornografia infantil como "qualquer representação, por qualquer meio, de uma criança no desempenho de atividades sexuais explícitas reais ou simuladas ou qualquer representação dos órgãos sexuais de uma criança para fins predominantemente sexuais" (artigo 2, c).

Este foi, também, o conceito adotado pela Lei $\mathrm{n}^{\mathrm{o}} 11.829$, de 2008, que modificou e acrescentou artigos ao ECA. O artigo 241-E do ECA dispõe que, "para efeito dos crimes previstos nesta Lei, a expressão "cena de sexo explícito ou pornográfica" compreende qualquer situação que envolva criança ou adolescente em atividades sexuais explícitas, reais ou simuladas, ou exibição dos órgãos genitais de uma criança ou adolescente para fins primordialmente sexuais".

A expressão "cena de sexo explícito ou pornográfica" se repete em vários artigos que foram acrescentados ao ECA ou modificados pela lei, escrita e discutida, basicamente, entre os profissionais (colaboradores) e parlamentares envolvidos nas atividades da CPI da Pedofilia do Senado Federal.

Em comentários a respeito da lei 11.829/08, SYDOW ${ }^{242}$ afirma que um dos grandes problemas da descrição legal foi que, buscando ser específica com a utilização da palavra

\footnotetext{
${ }^{240}$ A adequação dependerá do público envolvido no programa/projeto etc (pais, educadores, membros da comunidade, crianças/adolescentes). No caso específico das crianças/adolescentes, deverá ser adequado conforme o grau de maturidade e desenvolvimento. As reflexões a respeito das diferentes etapas de desenvolvimento são apresentadas na Parte II, Capítulo 4, deste trabalho.

${ }^{241}$ ORGANIZAÇÃO DAS NAÇÕES UNIDAS. Protocolo Facultativo à Convenção sobre os Direitos da Criança relativo à venda de crianças, prostituição e pornografia infantis. Disponível em http://www.unicef.pt/docs/pdf/protocolo_facultativo_venda_de_criancas.pdf, consulta em 14.11.2011.

${ }^{242}$ SYDOW, Spencer Toth. "Pedofilia virtual" e considerações críticas sobre a lei 11.829/08. Revista Liberdades IBCCrim n 1 - maio - agosto de 2009; p. 58. Apesar de ter sido editada em 2008, há escassos comentários doutrinários a respeito da lei; cf, também, a respeito, CONDACK, Cláudia Canto, Dos Crimes, in MACIEL, Kátia Regina Ferreira Lobo Andrade et allii. Curso de Direito da Criança e do
} 
"genital" (referente às genitálias - pênis e a vagina), deixou de abranger em seu conceito partes do corpo da criança e adolescente que são relevantes para a caracterização da pornografia infantil, como o ânus e os seios. "Assim, tendo-se em vista que não admite o Direito Penal a interpretação extensiva prejudicial ao réu, fica o aplicador da lei em difícil situação quando a exibição não tratar das genitálias, mas sim de outras partes do corpo igualmente relacionadas com a sexualidade".

De fato, muitas vezes, a opção legislativa de especificar a descrição das condutas, utilizando-se de rol taxativo (buscando cumprir a exigência da taxatividade da lei penal), gera o risco do efeito oposto: condutas que não se adequem exatamente à descrição típica acabam não sendo punidas, por não se admitir, no Direito Penal garantista, a analogia ou interpretação extensiva in malam partem.

$\mathrm{O}$ autor continua a crítica, considerando a definição adotada como teratológica. "O legislador além de fazer com que qualquer manifestação produzida pelo homem que envolva criança e adolescente em cenas reais de atividade sexual explícita fosse coibida, denominou cena pornográfica toda aquela que simule a participação de crianças ou adolescente; sendo assim, quadros, esculturas, desenhos, livros, filmes ou qualquer outra forma de expressão que utiliza ou utilizou representações infantes, ou meras insinuações em qualquer atividade sexual seriam em verdade pornografia infantil" 243

Mas haverá hipóteses de "manifestação produzida pelo homem que envolva criança e adolescente em cenas reais de atividade sexual explícita" que não sejam violadoras, da dignidade da criança/adolescente envolvida?

É possível elencar algumas. MESQUITA JUNIOR sugere a hipótese de um marido fotografar ou filmar a esposa adolescente, menor de 18 anos (lembrando que o casamento, no Brasil, é permitido a partir dos 16 anos, conforme o artigo 1517 do Código Civil) ${ }^{244}$. Aliás, ainda que não tenha havido casamento, o relacionamento sexual entre adultos e

adolescente- Aspectos Teóricos e Práticos - $4^{\mathrm{a}}$ Ed. Porto Alegre: Lumen Juris, 2010; p. 891-943; FARIAS, VILSON e HARTMANN, Gisele in "Lei 11.829/2008: Avanço para uns, incongruência para outros" e MESQUITA JÚNIOR, op. cit, Sidio Rosa de. A liberdade sexual do adolescente e a Lei no 11.829/2008. Jus Navigandi, Teresina, ano 13, n. 1979, 1 dez. 2008. Disponível em: <http://jus.com.br/revista/texto/12028. ${ }^{243}$ SYDOW, op cit.. op cit, p. 56.

${ }^{244}$ MESQUITA JÚNIOR, Sidio Rosa de. A liberdade sexual do adolescente e a Lei $\mathrm{n}^{\text {o }} 11.829 / 2008$. Jus Navigandi, Teresina, ano 13, n. 1979, 1 dez. 2008. Disponível em: <http://jus.com.br/revista/texto/12028>. Acesso em: 2 nov. 2011. 
adolescentes é legalmente permitido no Brasil, desde que o/a adolescente seja maior de 14 $\operatorname{anos}^{245}$. Isso, obviamente, não exclui a possibilidade de haver a filmagem/fotografia de um adolescente, por um adulto (ainda que seja namorado/a ou marido/a), sem o seu consentimento ou com consentimento viciado, mas certamente problematiza a questão.

Outra hipótese plausível seria a das próprias crianças/adolescentes envolverem-se em atividades sexuais e filmarem-se/fotografarem-se, por iniciativa própria, para seu próprio registro. Caso essas imagens se tornassem públicas, aí sim, haveria margem para questionamento - serão consideradas pornografia, a ponto de resultar na aplicação da lei penal? Ou a sua publicação daria ensejo, somente, a indenização civil? A resposta dependeria, certamente, de uma série de questões, como quem publicou (se as próprias crianças/adolescentes envolvidas - remeto para as considerações do capítulo anterior a respeito do sexting - ou adultos que tenham tido acesso ao material), como se deu o acesso etc.

Ao se pensar no conceito de pornografia infantil (e, consequentemente, na aplicação da lei), é preciso ponderar estas questões. Não há dúvidas que a intenção foi criminalizar a conduta de um adulto que faz fotografias ou filmagens de crianças/adolescentes durante a prática real de violência sexual ou aproveitando-se da ingenuidade da criança/adolescente para obter o seu consentimento.

A mais polêmica discussão no tocante ao conceito de pornografia infantil talvez seja aquela a respeito das cenas fantasiosas ou resultantes de montagens ou alterações digitais ("qualquer representação, por qualquer meio, de uma criança no desempenho de atividades sexuais explícitas reais ou simuladas”). A princípio, por terem sido produzidas sem o envolvimento de crianças e adolescentes na sua produção estas imagens não violariam os direitos de crianças e adolescentes.

\footnotetext{
${ }^{245}$ O estupro de vulnerável, conforme o art. 217-A do Código Penal, se caracteriza pela prática de ato sexual com menor de 14 (catorze) anos. Nas demais situações, deve-se provar que a relação sexual não foi consentida.
} 
Discutindo o conceito, SANZ MULAS ${ }^{246}$ diferencia a pornografia infantil em "pornografia infantil expressa", "pornografia técnica", "pornografia simulada ou pseudopornografia" e "pornografia virtual". Esses três últimos conceitos merecem atenção:

a) Pornografia técnica: disfarce da imagem de um adulto para que pareça um menor de idade, efeito que se obtém por meio de retoques e manipulação de fotografias ou filmes para apagar marcas de idade, rugas etc. Para a autora, esse tipo de pornografia apresenta menor lesividade; de modo que a tendência é pela não incriminação deste tipo de material. Ainda assim, na Alemanha e França, reformas penais foram introduzidas para tornar tais materiais típicos.

b) Pornografia simulada ou pseudo-pornografia: alteração de imagens de adultos com a introdução de imagens de menores reais, ou incorporando a uma imagem de criança objetos que deem a ela conotação sexual. Neste caso, a autora considera que há maior lesividade e a conduta pode ser objeto de sanção penal.

c) Pornografia virtual: criação de conteúdos sexuais com imagens não reais (desenhos, animações etc), de modo que não existem nem as situações nem as "pessoas" cuja imagem é veiculada. Nesse caso, a autora considera que não há lesão alguma.

SANZ MULAS reconhece o argumento, bastante utilizado, de que a pornografia virtual pode estimular o consumo de outros materiais que sejam produzidos com a real participação de crianças/adolescentes. Este argumento, aliás, é utilizado também para tentar incriminar os demais tipos de pornografia "não real" (técnica, simular ou virtual, segundo a classificação da autora).

Aliás, a Convenção de Budapeste sobre o Cybercrime, adotada pelo Conselho da Europa $^{247}$ e que é referência internacional, dispõe em seu artigo $9^{\circ}$ que os Estados-parte podem se reservar quanto à incriminação das imagens não reais e/ou simulações

\footnotetext{
${ }^{246}$ SANZ MULAS, Nieves. Pornografia en internet. Revista Penal, Barcelona, n. 23, p.181-202, jan. 2009; tradução livre da autora.

${ }^{247}$ COUNCIL OF EUROPE. Convention on Cybercrime. European Treaty Series - No. 185. Council of Europe. $\quad$ Budapest, 23.XI.2001. Disponível no site: http://www.conventions.coe.int/Treaty/Commun/QueVoulezVous.asp?NT=185\&CM=8\&DF=1/19/2007\&C L=ENG Data do download: 04/01/2011.
} 
envolvendo adultos ou representações e imagens não reais, criadas artificialmente que representem menores em práticas sexuais ${ }^{248}$.

A legislação argentina, por exemplo, não incrimina tais condutas. Segundo LANCMAN ${ }^{249}$, “con respecto a las imágenes que la figura penal menciona, es claro que deben corresponder a menores reales. Por lo tanto, quedan excluidas de toda relevancia típica las conductas de pornografía técnica o virtual o pseudofotografías consistentes en imágenes de supuestos niños obtenidos a partir de la distorsión de fotografías tomadas sobre personas adultas. Los supuestos de manipulación de imágenes pueden resultar punibles siempre que las mismas correspondan a menores auténticos".

No Brasil, o dispositivo acima mencionado, que define "cena de sexo explícito ou pornográfica envolvendo criança ou adolescente", é parte de um rol de artigos do ECA que foram, como já dito, modificados ou inseridos pela Lei 11.829, de 2008, que foi elaborada, votada e promulgada no calor das atividades da CPI da Pedofilia do Senado.

Os artigos 241-A a 241-C criminalizam a produção, distribuição, divulgação, publicação, posse e até mesmo a simulação de cenas de pornografia infantil. Por não serem objeto específico do presente trabalho, não serão discutidos esses artigos, portanto, sendo relevante, porém, a transcrição dos trechos considerados mais relevantes:

241-A. Oferecer, trocar, disponibilizar, transmitir, distribuir, publicar ou divulgar por qualquer meio, inclusive por meio de sistema de informática ou telemático, fotografia, vídeo ou outro registro que contenha cena de sexo explícito ou pornográfica envolvendo criança ou adolescente: (...)

$\S 1^{\circ}$ Nas mesmas penas incorre quem:

I - assegura os meios ou serviços para o armazenamento das fotografias, cenas ou imagens de que trata o caput deste artigo;

II - assegura, por qualquer meio, o acesso por rede de computadores às fotografias, cenas ou imagens de que trata 0 caput deste artigo.

$\S 2^{\circ}$ As condutas tipificadas nos incisos I e 11 do $\S 1^{\circ}$ deste artigo são puníveis quando o responsável legal pela prestação

\footnotetext{
248 BOITEUX, Luciana. Crimes informáticos: reflexões sobre política criminal inseridas no contexto internacional atual. Revista Brasileira de Ciências Criminais, São Paulo, v. 12, n. 47, p.146-187, mar./abr. 2004.

${ }^{249}$ LANCMAN, Valeria A. La pornografía infantil en internet. Ciencias Penales Contemporáneas: Revista de Derecho Penal, Procesal Penal y Criminología, Mendoza, v. 3, 5/6, p.291-319, 2003; p. 305. tradução livre da autora.
} 
do serviço, oficialmente notificado, deixa de desabilitar o acesso ao conteúdo ilícito de que trata o caput deste artigo.

"Art. 241-B. Adquirir, possuir ou armazenar, por qualquer meio, fotografia, vídeo ou outra forma de registro que contenha cena de sexo explícito ou pornográfica envolvendo criança ou adolescente: (...)

$\S 1^{\circ}$ A pena é diminuída de 1 (um) a $2 / 3$ (dois, terços) se de pequena quantidade o material se refere o caput deste artigo. (...)

Art. 241-C. Simular a participação de criança ou adolescente em cena de sexo explícito ou pornográfica por meio de adulteração, montagem ou modificação de fotografia, vídeo ou qualquer outra forma de representação visual: (...)

Parágrafo único. Incorre nas mesmas penas quem vende, expõe à venda, disponibiliza, distribui, publica ou divulga por qualquer meio, adquire, possui ou armazena o material produzido na forma do caput deste artigo.

\subsubsection{Atores envolvidos na (com a) violência sexual contra crianças e adolescentes.}

Cabe, por fim, diferenciar os atores envolvidos na violência sexual contra crianças e adolescentes. Não se trata de diferenciação meramente acadêmica ou didática. $\mathrm{O}$ uso indistinto dos termos dificulta o estabelecimento de estratégias de intervenção (penais ou não penais) diferenciadas; e, segundo DOS SANTOS, SANTOS e ESBER, “estratégias muito genéricas são invariavelmente pouco eficientes no enfrentamento da violência sexual contra crianças e adolescentes, pois tendem a recair naqueles agentes com menores imunidades institucionais. Além disso, o termo "agressor" termina por demandar intervenções de cunho meramente repressor, transformando a necessidade de responsabilização dos autores de violência sexual em "voracidade punitiva", uma atitude muito recorrente nas campanhas de enfrentamento da exploração sexual" ${ }^{250}$.

${ }^{250}$ DOS SANTOS, SANTOS, ESBER op cit; p.15; os autores afirmam, ainda, que a "ênfase na punição também acaba retardando o processo de criação de serviços de apoio psicossocial para autores de 
Na comunidade internacional, notadamente nos países anglo-saxões, é comum a utilização de termos como "agressor sexual" ou "ofensor sexual" (sexual offender), sendo, ainda, utilizados termos que remetem a características de seres humanos "primitivos", como "predador" (esta última, claramente, alinhada com as concepções positivistas acima mencionadas, como o "atavismo" Lombrosiano).

Digna de nota a discussão que foi promovida pelos pesquisadores do projeto Proinvert "Invertendo a Rota" 251 e registrada no livro de DOS SANTOS, SANTOS e ESBER, "Autores de Violência Sexual contra Crianças e Adolescentes: responsabilização e atendimento psicoterapêutico", razão pela qual optei por utilizar a obra como referência.

Preocupados com a inclusão de diferentes sujeitos, que praticaram diferentes condutas, na categoria única de "autor de violência sexual", DOS SANTOS, SANTOS e ESBER buscaram diferenciar as condutas e seus autores, indicando, ainda, que mesmo a posição final adotada no livro não refletiu de forma consensual as posições dos demais pesquisadores envolvidos.

Para os autores, as condutas praticadas por clientes, aliciadores e agenciadores do trabalho sexual de crianças e adolescentes estão mais relacionadas "com a dimensão "trabalho" ou "serviço" do que com a violência sexual em si. Portanto, a ação desses agentes deve ser enquadrada com maior propriedade na categoria "exploração do trabalho sexual", por estarem comprando ou induzindo ou, ainda, facilitando a venda de serviços sexuais de crianças e adolescentes, o que, conquanto seja uma violência, tem uma natureza distinta daquela observada nos atos cometidos por autores de violência sexual".

Os autores propõem, assim, uma especificação dos "agressores", diferenciando-os nas seguintes categorias, "buscando fugir das terminologias genéricas (...) que possuem baixo valor descritivo-analítico dos segmentos da população por elas compreendidos e que são altamente carregadas de juízos de valor $(\ldots)$ :

violência, uma vez que a criação de programas e serviços é quase sempre resultado da mobilização social."

${ }^{251}$ Para mais detalhes a respeito do Projeto Invertendo a Rota, cf. Capítulo 3, na Parte II deste trabalho. 
- perpetradores de abuso sexual: pessoas que praticam qualquer uma das categorias de abuso sexual (intra e extrafamiliar);

- autores de ato sexual violento: pessoas que praticam conjunção carnal por meio de violência, ameaça grave ou fraude;

- clientes do trabalho sexual: pessoas que compram serviços sexuais de trabalhadores do sexo, tradicionalmente denominados "prostitutos" ou prostitutas;

- aliciadores: pessoas que "atraem" ou "induzem" outras pessoas ao trabalho sexual com objetivos de ganhos materiais e financeiros;

- agenciadores de trabalho sexual: pessoas que agenciam o trabalho sexual de outrem para obter vantagens materiais e financeiras; esta é uma categoria ampla na qual se inclui o genericamente chamado "explorador do sexo comercial de crianças e adolescentes", ou seja, tanto o "rufião" e a "cafetina" quanto o "empresário da indústria do sexo"."252

O esforço dos autores foi no sentido de "relativizar os juízos de valor em relação à temática da violência sexual e desconstruir categorias de "apartação" dos indivíduos, que os encerram em estigmas obscurecedores de sua humanidade". Ao final da discussão, sugere-se que uma categoria globalizante seria, talvez, a de "autores de violações contra a dignidade sexual de crianças".

A categoria "pedófilo", tão cara aos Senadores que presidiram a CPI da Pedofilia, está ausente do rol acima. Considerando as categorias expostas, o "pedófilo" que pratica o ato sexual contra criança/adolescente poderia ser considerado perpetrador de abuso sexual, autor de ato sexual violento ou cliente do trabalho sexual. No entanto, nem todo perpetrador de abuso sexual, autor de ato sexual violento ou cliente do trabalho sexual é "pedófilo", ou seja, "portador da modalidade de "parafilia" classificada pelo DSM IV-TR19 como "pedofilia" e caracterizada pelo "foco do interesse sexual em crianças pré-púberes (geralmente, com 13 anos ou menos) por parte de indivíduos com 16 anos ou mais e que sejam ao menos cinco anos mais velhos que a criança, ao longo de um período mínimo de seis meses".

${ }^{252}$ DOS SANTOS, SANTOS, ESBER op cit; p.16-17. 
Desnecessário retomar aqui as considerações já feitas acima a respeito da pedofilia e dos efeitos nefastos que o uso inadequado do termo pode trazer, tanto para indivíduos que praticaram atos de violência sexual quanto para os que realizam atividades ligadas à exploração sexual, isso sem falar naqueles que, não tendo praticado conduta alguma, se veem, de repente, marcados pela letra escarlate: "pedófilo", correndo o risco de serem linchados pela multidão desejosa de se livrar de mais um monstro cruel.

Se não é objetivo deste trabalho estabelecer tais conceitos, por outro lado entendo que uma categoria mais ampla poderia ser utilizada para abarcar as diferentes modalidades de conduta envolvidas na violência sexual contra crianças e adolescentes. É que, na classificação acima, parece faltar a presença de condutas que são parte, especialmente, dos fluxos de tráfico de crianças para fins sexuais. Por exemplo, pais e mães que vendem seus filhos, ou transportadores de crianças. Esta específica conduta de venda e a conduta de transporte e intermediação não parecem, salvo melhor juízo, estar compreendidas nas categorias aliciadores e agenciadores de trabalho sexual, ao menos se compreendidas de modo estrito.

Entendo que a utilização da categoria atores envolvidos na (com a) violência sexual contra crianças e adolescentes poderia ser capaz de abarcar os diversos tipos de condutas elencados nas categorias acima, além de buscar retirar do sujeito a carga estigmatizante da sua nomeação a partir da conduta praticada (tanto quanto se pode buscar a não estigmatização quando se faz uma definição - o que é possível, mas extremamente difícil).

Ao se falar em ator envolvido na (com a) violência sexual contra crianças e adolescentes, busca-se, portanto, indicar que o sujeito de quem se fala não se reduz a esta característica (estigma), não estando, portanto, marcado para sempre por seus atos; pode o seu envolvimento com a violência sexual ter se dado de diversas maneiras e ter sido um episódio passageiro em sua vida. Ao mesmo tempo em que não o desresponsabiliza da gravidade do ato praticado, a categoria proposta retira a carga emocional incrustrada no termo "pedófilo", “explorador”, “ofensor” ou, o pior de todos eles, “predador". 


\subsection{Violência sexual contra crianças e adolescentes mediada pela TIC: abuso sexual on-line e aliciamento (grooming)}

A violência sexual contra crianças e adolescentes mediada pela TIC, no âmbito deste trabalho, pode ser entendida como uma modalidade de violência sexual cuja interação se dá por intermédio da tecnologia.

Segundo a organização canadense Cybertip, que recebe e encaminha as denúncias de crimes on-line contra crianças e adolescentes, os 5 principais riscos que crianças canadenses correm na internet são ${ }^{253}$ :

"1. Ofensores sexuais ${ }^{254}$ buscam jogos on-line que têm salas de conversa (chats) on-line, incluindo jogos interativos de computador;

2. Ofensores sexuais sequestram contas de mensagem instantânea [como msn] e coagem crianças e adolescentes a enviarem imagens nuas ou semi-nuas (...);

3. Ofensores sexuais utilizam avatares ${ }^{255}$ animados em $3 \mathrm{D}$ para envolver as crianças / adolescentes em conversas on-line;

4. Ofensores sexuais miram redes sociais [orkut, Facebook] onde as crianças e adolescentes são incentivados a criar diários on-line e travar contato com novas pessoas.

5. Jovens enviam imagens de nudez para seus pares, sem entender que as imagens podem ser reenviadas ou podem ficar permanentemente disponíveis on-line. ${ }^{256, "}$

O que se descreve acima nos itens 1 a 4 são, especialmente, modos de ação de atores envolvidos com a (na) violência sexual contra crianças e adolescentes para aliciar ou abusar sexualmente deles, utilizando-se, para tanto, das facilidades que a TIC oferece, como acesso a dados (fotos, informações etc) e acesso às próprias crianças. Com exceção do item 5, que descreve uma conduta praticada pelas próprias crianças/adolescentes (que

\footnotetext{
${ }^{253}$ Disponível em http://www.cybertip.ca/app/en/risks; tradução livre da autora.

254 A terminologia original no texto é sexual offenders.

255 "Em informática, avatar é a representação visual de um utilizador em realidade virtual. De acordo com a tecnologia, pode variar desde um sofisticado modelo 3D até uma simples imagem". (Fonte: wikipedia. Disponível em: http://pt.wikipedia.org/wiki/Avatar_(realidade_virtual)

${ }^{256}$ Esta prática, quando seus atores são crianças e adolescentes, é conhecida como sexting, já abordada no Capítulo 1 deste trabalho. A organização canadense se refere, aqui, especificamente, ao risco de as imagens das crianças/adolescentes, que deveriam permanecer entre eles próprios, serem utilizadas por terceiros ou chamarem a atenção de abusadores ou aliciadores para aquela criança/adolescente.
} 
pode ter consequências imprevistas, estimulando possíveis abusos), as descrições acima correspondem ao que aqui se está considerando como violência sexual mediada pela TIC.

SANZ MULAS ${ }^{257}$ aponta como riscos a que estão expostas crianças e adolescentes no cyberespaço os conteúdos inadequados (pornográficos, violentos, racistas etc); abuso físico (convites de pessoas que querem encontrar-se com eles, recebidos em conversas de chats on-line); ameaça (por meio de correio eletrônico, fóruns, chats etc); fornecimento de informação pessoal por ingenuidade (o que pode colocá-los em perigo e às suas famílias).

Os riscos mencionados são aqui agrupados sob dois diferentes nomes: abuso sexual on-line e aliciamento on-line para abuso, exploração sexual ou tráfico de seres humanos (grooming). É preciso lembrar, todavia, que a relação entre a violência sexual e a TIC vai além dessas condutas. Conforme se destacou anteriormente, além da pornografia infantil, que circula entre redes de usuários por meio da tecnologia, o turismo sexual com foco nas crianças e adolescentes também ganhou escala a partir do desenvolvimento das TIC.

Aqui, porém, o foco se dá na prevenção de condutas que possam iniciar-se e desenvolver-se on-line, em que um adulto interaja com as crianças/adolescentes, seja com o objetivo de induzi-la a praticar atos que proporcionem a ele prazer sexual ou para capturar suas imagens, seja com o objetivo de aliciá-la para um encontro pessoal, que pode ter como consequência o abuso, a exploração sexual ou o tráfico para fins sexuais, formas de violência sexual contra crianças e adolescentes acima discutidas.

\subsubsection{Pesquisas de vitimização e estatísticas oficiais}

Como já vem sendo reiterado desde o início desta exposição, não foram localizadas pesquisas nacionais com dados precisos indicando os principais riscos a que crianças e adolescentes brasileiras estão expostos durante suas interações on-line. As estatísticas de denúncias recebidas pela ONG SaferNet disponíveis para consulta ${ }^{258}$ não

${ }^{257}$ SANZ MULAS, Nieves. Pornografia en internet. Revista Penal, Barcelona, n. 23, p.181-202, jan. 2009; p. 184

${ }^{258}$ A Safernet é uma ONG que trabalha em conjunto com a Polícia Federal e o Governo Federal no recebimento e filtragem das denúncias de Crimes Cibernéticos. Central Nacional de Denúncias de Crimes Cibernéticos "A Central Nacional de Denúncias de Crimes Cibernéticos é única na América Latina e Caribe, 
diferenciam as situações de aliciamento, abuso e pornografia infantil. A única divisão existente é entre pornografia infantil e tráfico de pessoas, não sendo possível, ainda, identificar se a denúncia se trata de tráfico de pessoas adultas ou de crianças/adolescentes.

Além disso, as condutas de aliciamento e abuso sexual on-line somente recentemente foram tipificadas, conforme já mencionado, de modo que ainda não há estatísticas do Sistema de Justiça Criminal Brasileiro a respeito de eventuais inquéritos ou persecuções penais em juízo.

Os poucos dados disponíveis são os coletados nas pesquisas já mencionadas. Destacam-se os seguintes, ligados a comportamentos ou vivências de situações de risco on-line:

- dentre os estudantes entrevistados pela SaferNet, 12,1\% admitiram já ter postado fotos íntimas na rede ${ }^{259}$;

- segundo a mesma pesquisa, 60,08\% dos estudantes entrevistados afirmam ter medo de encontrar um amigo virtual pessoalmente;

- perguntados sobre situações vivenciadas em rede, 31,2\% dos participantes admitiram ter encontrado e/ou recebido conteúdo pornográfico; $24,12 \%$ tiveram dados roubados; 7,41\% sofreu alguma ação classificada como cyberbullying; e 3,01\% sofreu chantagens ou ameaças. Curiosamente, 33,56\% dos participantes disseram ter algum amigo que já sofreu cyberbullying. ${ }^{260}$

O Relatório do Círculo dos Direitos da CPP Brasil coletou, ainda, dados quantiqualitativos a respeito de comportamentos das crianças e adolescentes on-line. Segundo o

e recebe uma média de 2.500 denúncias (totais) por dia envolvendo páginas contendo evidências dos crimes de Pornografia Infantil ou Pedofilia, Racismo, Neonazismo, Intolerância Religiosa, Apologia e Incitação a crimes contra a vida, Homofobia e maus tratos contra os animais.

Para realizar este trabalho, foi desenvolvido um sistema automatizado de gestão de denúncias, baseado em Software Livre, que permite ao internauta acompanhar, em tempo real, cada passo do andamento da denúncia realizada por meio da Central Nacional de Denúncias. Do total de denunciantes, 99\% escolhem a opção de realizar a denúncia anonimamente. E ao 1\% restante é garantido total e completo anonimato." (http://www.safernet.org.br/site/institucional/projetos/cnd)

"A SaferNet disponibiliza nesta seção uma ferramenta interativa de estatísticas da Central Nacional de Denúncias de Crimes Cibernéticos. Por meio desta página é possível consultar o número de denúncias recebidas pela SaferNet, com a possibilidade de realizar pesquisas por tipo de crime e/ou por período. O sistema desenvolvido por nossa equipe de TI também oferece a geração instantânea de gráficos com base nos números apresentados". http://www.safernet.org.br/site/indicadores

${ }^{259}$ SaferNet Brasil, op cit, p.12-14.

${ }^{260}$ Idem, ibidem, p. 17. 
Relatório, "no Brasil, crianças e adolescentes estão conscientes dos riscos envolvidos em conversar com estranhos, mas quando perguntamos a elas se já haviam se encontrado pessoalmente com alguém que haviam conhecido on-line, $37 \%$ das meninas e $41 \%$ dos meninos disseram que sim".

Em parte dos casos, os encontros com alguém que conheceram on-line não resultam em risco real, como relata uma adolescente estudante de uma escola particular situada na cidade de Santo André:

"Eu estudava na mesma escola que um menino, mas não o conhecia. Nós nos encontramos no shopping center. No shopping center, não há muito perigo porque há muitas testemunhas, muita gente, e se alguma coisa acontecer, podemos correr. É difícil alguma coisa ruim acontecer." (Menina, Escola Trevo Master)

Situações particularmente preocupantes de assédio on-line, porém, foram relatadas por crianças que moram na periferia da cidade de São Paulo:

"Conheci uma pessoa pelo Orkut de um amigo e marcamos um encontro. Quando fui, vi que ela era bem mais velha; ela me chamou pelo nome, convidou para entrar no carro dela e falou que íamos para um local, que não quero falar onde é. Aí eu desci do carro rapidinho. Nunca mais me envolvo com ninguém assim.” (Menino adolescente, São Paulo)

"Meu amigo estava jogando na Lan house. O moço do computador ao lado dele começou a conversar com ele no msn e convidou o menino pra tomar sorvete. Depois, abordou o menino quando ele estava saindo da Lan house. Acho que aconteceu alguma coisa, porque o menino não quer mais falar sobre isso." (Menino, 15 anos, São Paulo)

Documento produzido pelo Instituto Australiano de Criminologia ${ }^{261}$ (AIC) oferece um panorama da produção a respeito da questão em diversos países, e apresenta alguns estudos vitimológicos que indicam o problema e sua extensão. Nota-se, ainda assim, que as pesquisas que investigam especificamente o aliciamento ou o abuso sexual on-line são incipientes, já que a maior parte dos esforços internacionais se concentra nas redes de produção e troca de pornografia infantil.

${ }^{261}$ CHOO, Kim-Kwang Raymond. Online child grooming: a literature review on the misuse of social networking sites for grooming children for sexual offences. Australian Institute of Criminology; 2009. Disponível em http://aic.gov.au/crime_types/cybercrime/prevention.aspx. 
A pesquisa "Growing Up with Media" ("Crescendo com a mídia") envolveu 1,588 crianças e adolescentes entre 10 e 15 anos entre Agosto e Setembro de $2006^{262}$. O estudo aponta que $35 \%$ relataram ter sido vítimas de solicitação sexual não desejada ou assédio on-line; $21 \%$ relataram ter praticado solicitação sexual não desejada ou assédio on-line; dentre os que relataram ter sido vítimas de solicitação sexual não desejada on-line, $15 \%$ informar que isto havia ocorrido pelo menos uma vez no ano anterior, e 3\% relataram que isso acontecia pelo menos uma vez por mês ou com mais frequência.

$\mathrm{Na}$ pesquisa realizada em 2006 nos EUA "Youth Internet Safety Survey" ("Pesquisa sobre a Segurança de Jovens na Internet"), adolescentes entre 10 e 17 anos entrevistados relataram exposição frequente e não desejada a material sexual, solicitação sexual e assédio on-line. Quatro por cento dos respondentes indicaram que pessoas que encontraram on-line solicitaram fotografias explícitas de nudez ou de sexo explícito; a pesquisa mostrou que os respondentes entre 14 e 17 anos estão mais sujeitos a receber solicitações sexuais on-line do que grupos de outras idades ${ }^{263}$.

A "Pesquisa sobre uso da Internet por crianças" ("Survey of Children's Use of the Internet"), realizada entre Dezembro de 2005 e Janeiro de 2006 entrevistou 848 estudantes entre 9 e 16 anos em 21 escolas irlandesas recebeu relatos de $7 \%$ dos respondentes indicando que haviam encontrado na vida real alguém que conheceram on-line; desses, 24 disseram que esta pessoa havia se apresentado on-line como criança e, quando o encontraram, constataram ser adulto.

O documento australiano cita, ainda, uma pesquisa nacional de vitimização on-line realizada nos EUA, no período de 1 ano (a partir de Julho de 2000), em que foram entrevistados 2574 investigadores de polícia; a pesquisa concluiu que, dentre os estimados 1,713 ofensores presos por posse de material de pornografia infantil, $36 \%$ tinham mostrado as imagens para crianças vítimas (ou para investigadores trabalhando on-line disfarçados de crianças). Desses, 36\% tinham intenção de aliciar as vítimas.

\footnotetext{
${ }^{262}$ Ybarra ML, Espelage DL \& Mitchell KJ 2007. The co-occurrence of internet harassment and unwanted sexual solicitation victimization and perpetration: associations with psychosocial indicators. Journal of adolescent health 41(6) Supplement 1: S31-S41 apud CHOO,. op cit, p. 20-.

${ }^{263}$ Mitchell K, Finkelhor D \& Wolak J 2007. Online requests for sexual pictures from youth: risk factors and incident characteristics. Journal of adolescent health 41(2): 196-203; apud CHOO, op cit.
} 
$\mathrm{Na}$ literatura internacional os achados das pesquisas de vitimização não são acompanhados de estatísticas oficiais. O documento do AIC sugere, ainda, que a violência sexual mediada pela TIC tem uma alta cifra negra. A relutância das vítimas em relatar as situações inclui o intenso impacto que a violência sexual tem nas vítimas e a falta de confiança na solução do caso pelo Sistema de Justiça. Há, ainda, uma dificuldade na comparação de dados oficiais porque os tipos penais são diferentes em cada um dos países, de modo que uma conduta que seria considerada crime em um deles, não o é em outro.

As estatísticas oficiais compiladas no documento, provenientes da Austrália, Reino Unido e Canadá, mostram que:

- 130 casos já foram perseguidos criminalmente na Austrália pelas práticas de aliciamento ou solicitação de exposição indevida on-line;

- No Reino Unido, o CEOP (Child Exploitation and On-line Protection Centre) recebe uma média de 10 denúncias por mês referentes a crianças entre 8 e 11 anos, a maioria referente a práticas de aliciamento; entre 2003 e 2007, o numero total de denúncias por ano passou de 185 para 322;

- $\quad$ Nos EUA, as denúncias de instigação on-line de crianças para a prática de atos sexuais, recebidas pelo National Center for Missing \& Exploited Children entre 1998 e 2005 pularam de 707 para 6.384/ano.

Apesar da ausência de estatísticas no Brasil, vê-se, pelos dados acima, que esses problemas são reais, e que, apesar de serem diferenciáveis, estão interconectados entre si e com a produção de pornografia infantil, o tráfico de crianças/adolescentes para fins sexuais, a exploração sexual etc. Mais do que isso, é possível que, em uma mesma situação fática, diversas condutas similares sejam praticadas, com enquadramento possível em mais de um dos novos tipos penais previstos no ECA.

\subsubsection{Abuso sexual on-Line, aliciamento (grooming) e violência sexual mediada pela TIC: definições}

A tradução literal do termo grooming é "arrumação" ou "preparação". A expressão vem do verbo "to groom". Outro termo comumente utilizado para referência à prática de 
aliciamento é luring (do verbo "to lure": atrair, seduzir). O uso dos termos é indiferente, embora grooming pareça ser utilizado com mais frequência na literatura internacional.

Em português, costuma-se usar a palavra aliciamento para descrever o processo pelo qual um adulto se aproxima de uma criança ou adolescente e a atrai para a exploração sexual; o termo não se aplica somente às atividades praticadas on-line, porém, abrangendo também as aproximações feitas pessoalmente e até mesmo a compra, venda ou troca de crianças para trabalhar (nas lavouras, carvoarias, serviço doméstico, prostituição etc).

Uma das definições de grooming é "linha de conduta adotada por um pedófilo suspeito, provocando em uma pessoa razoável uma causa para preocupação de que qualquer encontro com uma criança decorrente da conduta seria para fins ilegais ${ }^{264 \text {, }}$

Outra definição considera grooming como "os passos tomados por pedófilos para prender suas vítimas em armadilhas e que é, em alguns aspectos, análogo ao processo de conquista entre adultos" ${ }^{\prime 265}$.

As duas definições têm como (um dos) problema(s) o fato de utilizar o termo "pedófilos". Como acima discutido, o uso do termo de forma ampla é inapropriado por uma série de razões, já que restringe a possibilidade da prática de aliciamento ao portador da parafilia "pedofilia". Sabe-se, contudo, que é possível que o agente tenha a intenção de atrair a criança para se relacionar sexualmente com outra pessoa, com o intuito de lucro ou não.

O agente pode, também, estar interessado em obter fotos e vídeos da criança online para produção de material pornográfico ou ainda, apesar de estar buscando atrair uma criança/adolescente, não ter um interesse sexual especial ou exclusivo por crianças. Por fim, é sempre bom lembrar que o fato de que, para receber o diagnóstico de portador de transtorno de sexualidade caracterizado pelo foco do interesse sexual em crianças prépúberes, um indivíduo não precisa ter, previamente, praticado qualquer ato para realizar o

\footnotetext{
264 "Course of conduct enacted by a suspected paedophile, which would give a reasonable person cause for concern that any meeting with a child arising from the conduct would be for unlawful purposes (O'Connell 2003 cited in Craven, Brown \& Gilchrist 2006: 288)" apud CHOO, op. cit.p.2; tradução livre da autora.

265 "The steps taken by paedophiles to 'entrap' their victims and is in some ways analogous to adult courtship (Howitt 1995 cited in Craven, Brown \& Gilchrist 2006: 288)" apud CHOO, op. cit.; p.2; tradução livre da autora.
} 
seu interesse; do mesmo modo, receber o diagnóstico não significa que o indivíduo irá praticar tais atos.

As definições acima têm ainda o problema de serem muito vagas ou de se utilizarem de termos que indicam juízo de valor, como "prender a vítima em uma armadilha".

Em recente publicação, o UNICEF adotou a seguinte definição para on-line grooming: um processo intencionado para atrair crianças à prática de comportamento sexual ou conversações, com ou sem o conhecimento delas, ou um processo que envolve comunicação e socialização entre o ofensor e a criança com o fim de torná-la mais vulnerável ao abuso sexual ${ }^{266}$.

$\mathrm{Na}$ extensa revisão de literatura realizada pelo AIC, o autor não chega a propor uma definição ou conceito alternativo ${ }^{267}$. Mais adiante, porém, CHOO utiliza a seguinte expressão para se referir ao grooming/aliciamento on-line: "um comportamento premeditado com a intenção de assegurar a confiança e a cooperação de crianças, antes de se engajar em uma conduta sexual" ${ }^{268}$. A definição é adequada por não se referir a um autor específico, bem como por se prender à descrição do que é o aliciamento ${ }^{269}$. Porém, ela não especifica se a intenção é assegurar a confiança e a cooperação da criança para engajamento em uma conduta sexual on-line ou off-line. A partir do conceito de grooming, portanto, pode-se considerar que o agente poderia 'preparar' a criança seja para o abuso sexual on-line ou off-line.

Quanto ao abuso sexual on-line, duas definições foram encontradas.

\footnotetext{
266 "Online grooming - Defined by various authors and used in this report to describe a process intended to lure children into sexual behaviour or conversations with or without their knowledge, or a process that involves communication and socialization between the offender and the child in order to make him or her more vulnerable to sexual abuse. The term 'grooming' has not been defined in international law; some jurisdictions, including Canada, use the term 'luring'". UNICEF ; Innocenti Research Centre. Child Safety Online: Global challenges and strategies; Dezembro de 2011. Disponível em http://www.unicefirc.org/publications/pdf/ict_eng.pdf, consulta em 15/01/2012; p. 31.

${ }^{267}$ Após a análise dos conceitos acima transcritos, o autor indica que os critérios para seleção dos casos e estudos que compõem o estudo terá como parâmetro as definições contidas nos tipos penais da legislação estadunidenses. Um dos critérios legais estabelecidos é a diferença de idade entre vítimas e agentes: no mínimo, 18 anos para o agente e no máximo 16 anos para a vítima.

268 "a premeditated behaviour intended to secure the trust and cooperation of children prior to engaging in sexual conduct." CHOO, op cit, p.7.

${ }^{269}$ Como a intenção, no presente trabalho, não é chegar a um conceito jurídico penal de aliciamento, considero-a suficientemente boa para os propósitos pretendidos.
} 
Segundo o UNICEF, abuso sexual on-line é a produção, distribuição, download ou visualização de material de abuso (imagens em vídeo ou parada), também conhecida como pornografia infantil; solicitação on-line de crianças e jovens para auto-produção de material de abuso de crianças, para engajá-los em chats sexuais ou outras atividades sexuais on-line, ou para arranjar um encontro off-line com o propósito de atividade sexual, também conhecido como grooming ou luring; qualquer facilitação de qualquer uma das atividades acima"270. Ainda de acordo com o UNICEF não há uma definição consensual de abuso sexual on-line na comunidade internacional.

O problema desta definição é que ela, além de muito abrangente, inclui a definição de pornografia infantil.

Há, ainda definição da ONG Internacional Childhood Brasil, que é mais descritiva:

"Jogo sexual imposto por um adulto a uma criança ou a um adolescente via internet (por meio das ferramentas de bate-papo, como chats, e-mails e sites de relacionamento) e que envolvem nudez e masturbação diante de webcams, veiculação de fotos eróticas ou pornográficas, exibição dos genitais, uso de linguagem sexual, aliciamento para fins sexuais, entre outras práticas abusivas. Pode resultar em convites marcando encontros secretos com vistas ao abuso ou à exploração sexual"271.

Esta definição indica que há uma conexão e confusão entre os fenômenos, ou seja, o abuso sexual on-line pode ser apenas um passo para o grooming/aliciamento (e também para a produção de material de pornografia infantil) ou pode se esgotar com a prática dos atos sexuais mediados pela TIC (on-line).

Por sua vez, o grooming pode ser uma preparação para a prática de abuso sexual on-line, ou pode resultar em um encontro efetivo com a criança/adolescente, no qual ela

\footnotetext{
270 “online child sexual abuse - Production, distribution, downloading or viewing of child abuse material (both still and video images), also known as child pornography; online solicitation of children and young people to produce self-generated child abuse material, to engage them in sexual chat or other online sexual activity, or to arrange an off-line meeting for the purposes of sexual activity, also known as grooming or luring; and facilitation of any of the above. There is no agreed definition of online child sexual abuse in international law; for the purposes of this report, the term is defined as noted above." UNICEF ; Innocenti Research Centre. Child Safety Online: Global challenges and strategies; Dezembro de 2011. Disponível em http://www.unicef-irc.org/publications/pdf/ict_eng.pdf, consulta em 15/01/2012; p. 31.

271 Site da Childhood Brasil. http://www.childhood.org.br/entenda-a-questao/glossario; Consulta em $06 / 01 / 2011$
} 
corre o risco de ser abusada ou passar a ser explorada sexualmente, inclusive fazendo parte de redes de turismo sexual. Ela também pode vir a ser vítima de tráfico nacional ou internacional de pessoas.

Não há, como se vê, clareza com relação aos limites dos termos aliciamento e abuso sexual on-line. Há ainda quem utilize a expressão exploração sexual on-line para abranger qualquer conduta on-line que leve à prática de atos sexuais por crianças. Porém, o conceito de exploração sexual, como visto acima, é mais adequado para caracterizar as "relações sexuais comerciais" (prostituição), o que o torna impreciso, já que restringe o objeto.

Por esta razão, aliás, é que se opta, nesta pesquisa, pelo termo violência sexual mediada pela TIC. O termo violência sexual, já acima discutido, abarca as práticas de abuso sexual e exploração sexual (pornografia infantil, tráfico para fins sexuais, turismo sexual e prostituição) e as suas conexões e práticas on-line.

A violência sexual mediada pela TIC restringe o conceito de violência sexual para abranger somente as situações em que um adulto interage com uma criança/adolescente, por meio da tecnologia, para a prática de atos sexuais on-line (que, por sua vez, estão interconectados com as demais formas de violência sexual on ou off-line). Esta restrição se pretende deixar clara com o uso do verbo mediar, já que ele indica que aquela relação acontece não presencialmente, mas mediada por uma tecnologia.

Desse modo, opta-se por restringir a prevenção vitimal, objeto desta pesquisa, às situações que crianças e adolescente vivenciarão utilizando a tecnologia, pois será possível interferir positivamente no processo de interação entre elas e possíveis atores envolvidos com a (na) violência sexual, empoderando crianças e adolescentes para sua proteção. 


\subsubsection{Aliciamento (grooming) e abuso sexual on-line: dinâmicas}

Pesquisadores descrevem o aliciamento como um processo com etapas claramente definidas $^{272}$. Para simplificar a descrição, utilizarei somente o termo criança para referência a crianças e adolescentes.

O primeiro estágio é identificado como de conquista de amizade, no qual o adulto busca se aproximar da criança para conhecê-la. Sites exclusivos para crianças, site de jogos infantis on-line, redes sociais são locais onde é possível conhecer crianças e se aproximar delas, por meio de chats e mensagens. A seguir, passa-se para o estágio de relacionamento, com a intenção de saber mais sobre a vida, a escola, a família da criança, mas também para criar uma sensação de "melhor amigo". O terceiro estágio é o de avaliação de risco, em que o adulto procura se certificar das condições em que a criança utiliza a tecnologia em sua casa (por exemplo, se o computador está no quarto ou na sala, quem mais usa o computador etc).

O estágio da exclusividade introduz uma maior intimidade nas conversas. $\mathrm{O}$ adulto mostra que compreende a criança, e que ela pode se sentir à vontade para conversar com ele. Isso induz a confiança e uma sensação de respeito mútuo. Somente a partir deste ponto é que se iniciam as conversas sobre sexualidade, que pode incluir perguntas sobre as atividades sexuais da criança (se já foi beijada, se costuma tocar o próprio corpo etc).

A partir do momento em que se iniciam as conversas sobre sexualidade, diversos desdobramentos podem ocorrer. Com a confiança estabelecida previamente e fortalecida a cada encontro, o adulto pode querer criar na criança uma sensação de que ele é seu mentor, e que talvez ele seja seu amante no futuro. Quando a criança hesita, sentindo-se pressionada ou invadida, o adulto tende a apelar para esta confiança estabelecida, expressando tristeza, ao que, habitualmente, a criança responderá com o perdão, restabelecendo o vínculo.

272 O'Connell, Rache. A Typology of Child Cybersexploitation and Online Grooming Practices. Cyberspace Research Unit; University of Central Lancashire (UCLan), United Kingdom, p. 97-100; CARDIN, Valéria Silva Galdino e BARRETO, Maíra de Paula. Da Pedofilia E Dos Direitos Da Personalidade Da Criança. Anais do Congresso Nacional do CONPEDI (Conselho Nacional de Pesquisa e Pós-Graduação em Direito); p 3983-4012; disponível em http://www.conpedi.org.br/anais/36/14_1172.pdf, consulta em 05/09/2011; CHOO, op cit, p. 
Essas estratégias são também chamadas de dessensibilização, que é a introdução gradual de elementos sobre a sexualidade na vida da criança, buscando familiarizá-la com aquilo que, para ela, pode ser ainda algo desconhecido. Para isso, pode haver compartilhamento de detalhes pessoais íntimos da vida sexual do adulto com a criança. Pode-se, ainda mostrar fotos de outras crianças envolvidas em situações de sexo (pornografia infantil).

As conversas sobre sexo podem variar, incluindo descrições mais ou menos explícitas sobre como se masturbar, como masturbar o parceiro, como se faz sexo oral etc. A ideia de que aquele adulto pode ser o mentor da criança acaba servindo como justificativa, sugere-se que a criança aprenderá mais sobre sua sexualidade e, eventualmente, poderá vir a ser um bom amante, podendo até mesmo se encontrar com o adulto pessoalmente depois.

Quanto maior a intimidade, abre-se o espaço para que o adulto sugira à criança que tire fotografias de si mesma e envie para ele, ou que abra a câmera do computador e se mostre para ele, ou ele pode querer se mostrar para a criança.

Este passo pode dar ensejo a estratégias mais agressivas, como a "chantagem online": uma vez obtidas fotos e vídeos da criança (que podem ter sido enviados por ela ou tirados pelo próprio adulto, durante as conversas), passa a manipular fotos, colocando o rosto da vítima em cenas de sexo. Pode haver, então, ameaças de divulgação das fotos manipuladas para humilhar a criança diante de amigos e familiares em sites; ameaça de agressão presencial em casa ou na escola.

As imagens dessa criança podem ser, posteriormente, utilizadas em montagens e ser distribuídas em formato de vídeo ou de fotos pelas redes de trocas de pornografia infantojuvenil existentes na rede.

O último passo do processo pode ser o convite para um encontro pessoal com o adulto. Esse encontro pode resultar em abuso sexual ou na inserção da criança na exploração sexual e, nos casos mais graves, a morte. 
A literatura ${ }^{273}$ a respeito de abuso sexual contra crianças e adolescentes é praticamente unânime ao identificar a chamada "síndrome do segredo na criança abusada", ou "síndrome do silêncio", que explica o fato de muitas crianças serem vitimizadas durante longos períodos, de forma reiterada, sem que consigam revelar o abuso.

Segundo a literatura, a relação de confiança criada entre o adulto e a criança em uma dinâmica de abuso sexual pode estabelece entre eles uma cumplicidade, que é estimulada pelo adulto por meio de estratégias acima citadas. No caso do abuso sexual "real", é comum o adulto deixar com que a criança faça atividades que os pais não permitiriam (por exemplo, um passeio ou uma guloseima proibidos), o que dá então margem ao estabelecimento do segredo (“eu não vou contar nada se você não contar”).

Uma vez estabelecida esta relação, torna-se muita vezes extremamente difícil para a criança reportar o abuso; ela se sente culpada por trair a confiança do adulto. Além disso, é comum o relato na literatura de crianças sentirem-se culpadas pelo abuso sexual, por terem sentido prazer em algum momento ou pelo fato de nutrirem afeto pelo adulto e sentirem que, de algum modo, estimularam ou consentiram com a prática do abuso.

Mas a literatura ${ }^{274}$ ainda lista outras razões para o silêncio, além da relação acima, considerada como sendo de "sedução":

- “Ameaças físicas ou psicológicas que fazem com que a criança tema por si, por sua família ou por alguém por quem nutra afeto;

- Crianças mais novas, que não possuem conhecimento das coisas do sexo, podem ver o abuso sexual como algo normal e, portanto, não se sentem impelidas a relatar o ocorrido;

- Distorção da realidade - o abusador manipula a realidade da crianças, de modo que ela sinta que é a abusadora, e ele, a vítima, conseguindo, assim, alterar, pelo menos psicologicamente, os papéis que cada um exerce na ação;

- Medo da perda da atenção do abusador, pessoa que a seduziu e por quem nutre afeto;

\footnotetext{
${ }^{273}$ Cf, a respeito CEZAR. Depoimento sem Dano... p. 46-49; RIBEIRO; MANITA, Crianças vítimas de abuso sexual intra-familiar...; BUENO ARÚS. Victimología infantil...; AZEVEDO, Maria Amélia. Consequências psicológicas da vitimização de crianças e adolescentes; SILVA, Célia Nunes et al. Efeitos psicossociais e jurídicos nas vítimas de crimes sexuais... p 90-91.

${ }^{274}$ Exemplos retirados de CEZAR, op cit. p. 46-48.
} 
- Medo da punição pela ação que participou;

- Medo de que não acreditem nela e que por isso possam puni-la pela mentira;

- Culpa pela ação que participou - não no sentido legal, mas no sentido psicológico - eis que queria ou não, a criança está ligada à interação abusiva, ainda que participando de forma passiva. A criança equivoca-se, pensando ter participado ativamente do abuso e também ser responsável pela sua ocorrência;

- Falta de evidência médica acerca do abuso."

Apesar de a descrição da síndrome do segredo estar ligada a abuso sexual "real", a dinâmica do abuso sexual on-line indica que o fenômeno pode estar também presente nestas situações. A literatura examinada reporta situações em que o adulto, por exemplo, chantageia a criança/adolescente após obter fotos ou imagens suas, o que pode ser suficiente para garantir que o segredo permaneça intacto durante um considerável período de tempo.

Ao considerarmos somente a prática da violência sexual on-line, fica claro que se trata de violência psicológica ou psíquica, traduzindo-se, de maneira geral, em efeitos psíquicos prejudiciais ao desenvolvimento saudável (inclusive o sexual), à dignidade e à honra de crianças e adolescentes.

Não se descarta, todavia, que haja possibilidade de, mesmo sem contato físico algum com o autor de violência sexual on-line, haver dano físico de várias proporções, autoinfligido pela vítima, como uma decorrência da violência psicológica praticada ${ }^{275}$.

\subsubsection{Aliciamento (grooming) e abuso sexual on-line: tipos penais.}

O aliciamento (grooming) e o abuso sexual on-line foram incluídos entre as condutas penalmente proibidas pela já mencionada Lei nº 11.829, de 2008.

As condutas proibidas pelo artigo 241-D são "aliciar, assediar, instigar ou constranger, por qualquer meio de comunicação, criança, com o fim de com ela praticar ato libidinoso" (caput), aplicando às mesmas penas a quem "facilita ou induz o acesso à

\footnotetext{
${ }^{275}$ Confira, adiante, a respeito dos indicadores de violência sexual em crianças e adolescentes.
} 
criança de material contendo cena de sexo explícito ou pornográfica com o fim de com ela praticar ato libidinoso" e "pratica as condutas descritas no caput deste artigo com o fim de induzir criança a se exibir de forma pornográfica ou sexualmente explícita" (parágrafo único, incisos I e II). As penas previstas são de reclusão, de 1 (um) a 3 (três) anos, e multa.

Conforme a descrição acima, durante a interação pode haver, ainda, a produção de fotografia ou filme da criança/adolescente e o armazenamento destas imagens pelo adulto. Nesse caso, os artigos 241-B ("adquirir, possuir ou armazenar, por qualquer meio, fotografia, vídeo ou outra forma de registro que contenha cena de sexo explícito ou pornográfica envolvendo criança ou adolescente") e 240 ("Produzir, reproduzir, dirigir, fotografar, filmar ou registrar, por qualquer meio, cena de sexo explícito ou pornográfica, envolvendo criança ou adolescente") poderiam, eventualmente, ser aplicáveis, apesar de ser possível entender que essas condutas poderiam ser absorvidas pela previsão do artigo 241-D, já que fazem parte do processo de aliciamento ${ }^{276}$.

Para SYDOW, o tipo penal do art 241-D desvirtua as funções do Direito Penal. Isso porque entende que sendo "rede mundial de computadores um ambiente de risco assim como o mundo real, mas potencializado, caberia aos pais restringirem o uso de tal instrumento" Segundo o autor, "há notoriedade acerca do fato de que conteúdos pornográficos de todos os estilos permeiam a rede. Assim, a criança ou adolescente que ingressa em ambientes de sexualidade exacerbada como salas de bate-papo e comunidades virtuais será, como qualquer outro usuário, assediado e instigado. A anonimidade virtual leva o delinquente a buscar a satisfação de sua sexualidade ou sua fantasia e a presença da criança em certos ambientes com consequente ofensa chega a poder ser interpretada como uma concorrência de culpas: do ofensor e do genitor que não cumpriu os deveres de cuidado quanto ao seu filho". ${ }^{277}$ [destaquei]

Com a devida vênia, a interpretação do autor beira as raias do absurdo. Entendendo que o autor se alinha aos princípios do Direito Penal Mínimo, querendo, com isso, defender a restrição do Direito Penal aos casos em seja estritamente necessária, buscando uma interpretação restrita da norma, atendendo aos princípios de ofensividade, lesividade, e, eventualmente, tendo em mente elementos como o da autocolocação da 
vítima em risco e outras orientações hermenêuticas advindas do funcionalismo penal alemão, que cita em seu artigo.

Porém, exagera em sua interpretação. Desconsidera completamente os direitos de crianças e adolescentes e ignora uma situação real e violenta, que foi caracterizada acima. Revela desconhecimento da vulnerabilidade natural de crianças e adolescentes, de seu processo de desenvolvimento, da impossibilidade de pais e educadores controlarem cada passo dado por seus filhos, da realidade de milhares de crianças e adolescentes que acessam a tecnologia em lan houses, sem qualquer tipo de orientação.

Revela desconhecimento do impacto que o abuso sexual on-line pode ter na criança, parecendo desconhecer o conceito de violência psíquica, e de dano atual e futuro, conforme discussão acima a respeito das concepções doutrinárias sobre violência sexual.

Aliás, o próprio argumento de que a rede mundial de computadores é similar ao mundo real já seria suficiente para colocar o comentário que realiza em contradição. Se a rede de computadores é similar ao mundo real, e é responsabilidade dos pais proteger seus filhos da conduta de adultos que pretendem aliciá-las ou abusar sexualmente delas, então todos os pais deveriam ser co-culpabilizados pela abordagem de suas crianças na porta da escola, ou pelo rapto de seus filhos nos parques públicos, ainda que não houvesse dano físico para a criança.

E, continua o autor, "certamente que o intuito do legislador não foi o de punir todo e qualquer aliciamento no intuito da prática de ato libidinoso com menor, mas punir os atos preparatórios de um possível atentado violento ao pudor com violência presumida, reduzindo as chances de execução do delito. No caso, pode-se entender pela existência de certa potencialidade ofensiva." [destaquei]

De fato, os atos de aliciamento podem ser considerados atos preparatórios para um crime de estupro. Porém, o crime de estupro pode não acontecer, o que não retira a inegável lesividade do processo acima descrito, pelo qual passa a criança que é aliciada e abusada, ainda que virtualmente. Conforme se verá nos capítulos seguintes, o desenvolvimento infantil se dá em etapas, e "atravessar" essas etapas, estimulando precocemente a sexualidade, fazendo com que a criança se toque, se exponha, veja 
imagens de outras crianças praticando sexo etc pode provocar lesões extremamente importantes à sua personalidade atual e futura.

Se, para o adolescente, pode ser que o abuso sexual on-line não tenha grandes repercussões, e uma tentativa de aliciamento resulte somente em perturbações passageiras, para uma criança - lembremos que crianças iniciam o uso da tecnologia por volta dos 7 anos - os efeitos podem ser devastadores, não só com relação ao seu desenvolvimento sexual, mas com relação a diversos outros aspectos de seu desenvolvimento, conforme se verá no item abaixo e se demonstrará nos Capítulos seguintes.

\subsubsection{Os danos efetivos e potenciais às crianças e adolescentes decorrentes da violência sexual mediada pela TIC}

Há escassa produção específica a respeito dos efeitos da violência sexual mediada pela TIC, nas modalidades que compõem o delineamento aqui proposto, em crianças e adolescentes. A este propósito, revisão de literatura abrangente recentemente realizada pelo Instituto Australiano de Criminologia identificou, num estudo do Programa "Internet Segura e Tecnologias on-line para crianças" da Comissão Européia (European Commission Safer Internet and On-line Technologies for Children Program) a necessidade de estudos sobre o "impacto psicossocial nas crianças e adolescentes decorrentes de situações on-line e a forma como crianças reagem aos predadores on-line" 278 . Recomendação semelhante, entre diversas outras, é feita em relatório de força tarefa do Governo Canadense a respeito ${ }^{279}$ da segurança dos jovens on-line: são necessárias pesquisas sobre os "efeitos, a curto e longo prazo, de contatos com conteúdos on-line inapropriados para a idade ou potencialmente ofensivos e de comportamentos de risco inadequados".

\footnotetext{
${ }^{278}$ Outros temas identificados como carentes de pesquisa foram: "Quais são os grupos mais vulneráveis entre as crianças e como apoiá-los; A relação entre a qualidade da parentalidade e o grooming, bem como a relação entre a depressão e o grooming tanto nas vítimas quanto no agressor; Ofensores e o comportamento de grooming, incluindo a tipologia e perfil de agressores sexuais online". European Commission Information Society and Media Directorate-General 2007, apud Kim-Kwang Raymond Choo. Online child grooming: a literature review on the misuse of social networking sites for grooming children for sexual offences. Australian Institute of Criminology, 2009. Disponível em http://aic.gov.au/crime_types/cybercrime/prevention.aspx; tradução livre da autora

${ }^{279}$ THE ONLINE SAFETY AND TECHNOLOGY WORKING GROUP. op cit, p. 66.; tradução livre da autora.
} 
Há, contudo, inúmeros trabalhos que buscam identificar sinais que denotam a violência sexual real em crianças e adolescentes. Opto aqui pela utilização dos conteúdos contidos no já referenciado documento "Guia Escolar: métodos para identificação de abuso e exploração sexual de crianças e adolescentes", publicação da Secretaria Especial de Direitos Humanos e Ministério da Educação que é referência a respeito da temática, por ter sido elaborada por pesquisadores respeitados que há muito se dedicam ao estudo da violência sexual contra crianças e adolescentes.

Foram revisados diversos artigos e obras ${ }^{280}$ que listam os efeitos a curto, médio e longo prazo da violência sexual em crianças e adolescentes, podendo considerar-se tais informações como representativas da literatura criminológica autorizada a respeito da temática.

O documento apresenta duas listas de sinais que podem ser indicadores de violência psicológica e de violência sexual (física) contra crianças e adolescentes. Os

${ }^{280}$ CHOO, Kim-Kwang Raymond. Online child grooming: a literature review on the misuse of social networking sites for grooming children for sexual offences. Australian Institute of Criminology; 2009. Disponível em http://aic.gov.au/crime_types/cybercrime/prevention.aspx; FALEIROS, Eva T. Silveira; RADICCHI, Lis Celia Arantes. Pedofilia: Adoecimento e crime. Revista Juridica Consulex. Brasilia, v.14, n.315, p.35-37, fev. 2010; FALEIROS, V. P. e FALEIROS, E. T. S.(coords.). Circuito e Curto- Circuitos: atendimento, defesa e responsabilização do abuso sexual contra crianças e adolescentes no Distrito Federal. CECRIA, São Paulo, Veras Editora, 2006.; HERRERA MORENO, Myriam. El niño ante la agresión doméstica: malos tratos y abuso sexual. Cuadernos de Política Criminal, Madrid, n. 54, p.11131141, 1994.; UNGARETTI, Maria America (org.) Criança e Adolescente: Direitos, Sexualidades e Reprodução. São Paulo: Associação Brasileira de Magistrados, Promotores de Justiça e Defensores Públicos da Infância e da Juventude - ABMP.; LIBÓRIO, Renata Maria Coimbra \& SOUSA, Sônia M. Gomes (organizadoras). A Exploração Sexual de Crianças e de Adolescentes no Brasil. Reflexões teóricas, relatos de pesquisas e intervenções psicossociais. São Paulo: Casa do Psicólogo. Goiânia: Universidade Católica de Goiás, 2004; MIGUEL QUEREJETA, Luis. Estructura de la personalidad del menor víctima de maltrato: daños psicológicos y lesiones físicas. Eguzkilore: Cuaderno del Instituto Vasco de Criminología, San Sebastian, n. 13, p.53-65, dez. 1999.; SILVA, Célia Nunes et al. Efeitos psicossociais e jurídicos nas vítimas de crimes sexuais. In: Seminário. Núcleo de Atendimento a Vítimas de Crimes Violento, NAVCV,5-6º Construção da cidadania: desdobramento dos atendimentos às vítimas de violência; violência, vítima e direitos humanos. São Paulo: NAVCV, 2005-2006. ; SANZ MULAS, Nieves. Pornografia en internet. Revista Penal, Barcelona, n. 23, p.181-202, jan. 2009; SUBIJANA ZUNZUNEGUI, Ignacio José. La victimología infantil: niños víctimas de agresión sexual y sistema judicial. Eguzkilore: Cuaderno del Instituto Vasco de Criminología, San Sebastian, n. 13, p.67-84, dez. 1999.; VÁZQUEZ, Marcelo Pablo. La explotación sexual comercial de la niñez y su relación con la red internet. Cuadernos de Doctrina y Jurisprudencia Penal, Buenos Aires, v. 10, 18/19, p.643-692, nov. 2005.; AZEVEDO, Maria Amélia. Consequências psicológicas da vitimização de crianças e adolescentes. In: AZEVEDO, Maria Amélia; GUERRA, Viviane Nogueira de Azevedo. Crianças vitimizadas: a síndrome do pequeno poder. São Paulo: Iglu, 2000. 211 p. ISBN 85-85631-81-3. p.143-167.; BUENO ARÚS, Francisco. Victimología infantil: tipología : formas de maltrato: ñinos víctimas de agresión sexual. Eguzkilore: Cuaderno del Instituto Vasco de Criminología, San Sebastian, n. 13, p.41-51, dez. 1999.; Construindo uma história: tecnologia social de enfrentamento à violência sexual contra crianças e adolescentes / Centro de Defesa da Criança e do Adolescente da Bahia ROUSSAN, Yves de. - Salvador: CEDECA-BA, 2003. 340p.; CEZAR, José Antônio Daltoé. Depoimento sem Dano: Uma alternativa para inquirir crianças e adolescentes nos processos judiciais. Porto Alegre: Livraria do Advogado Editora, 2007. 
indicadores de violência psicológica em crianças e adolescentes, por exemplo, podem ser de ordem física ou comportamental, a saber:

1. Indicadores físicos: Problemas de saúde sem causa orgânica: distúrbios de fala, distúrbios de sono, afecções cutâneas, disfunções físicas em geral;

2. Indicadores comportamentais: isolamento social, carência afetiva, baixo conceito de si próprio, regressão a comportamentos infantis; submissão e apatia, dificuldades e problemas escolares, tendência suicida ${ }^{281}$.

Destacam-se, ainda os seguintes indicadores de violência sexual no curto e médio prazo referidos no mesmo documento ${ }^{282}$ :

- Medo ou mesmo pânico de certa pessoa ou sentimento generalizado de desagrado quando a criança é deixada sozinha em algum lugar com alguém.

- Medo do escuro ou de lugares fechados.

- Mudanças extremas, súbitas e inexplicadas no comportamento.

- Regressão a comportamentos infantis, como choro excessivo sem causa aparente, enurese.

- Tristeza, abatimento profundo ou depressão crônica. Fraco controle de impulsos e comportamento autodestrutivo ou suicida.

- Baixo nível de autoestima e excessiva preocupação em agradar os outros.

- Vergonha excessiva

- Culpa e autoflagelação.

- Ansiedade generalizada, comportamento tenso, sempre em estado de alerta, fadiga.

- Comportamento disruptivo, agressivo, raivoso.

- Alguns podem ter transtornos dissociativos na forma de personalidade múltipla.

- $\quad$ Expressão de afeto sensualizada ou mesmo certo grau de provocação erótica, inapropriado para uma criança.

- Desenvolvimento de brincadeiras sexuais persistentes com amigos, animais e brinquedos.

- Masturbar-se compulsivamente.

- Abandono de comportamento infantil, de laços afetivos.

- Mudança de hábito alimentar - perda do apetite (anorexia) ou excesso (obesidade).

- Padrão de sono perturbado por pesadelos freqüentes, agitação noturna, gritos, suores, provocados pelo terror de adormecer e sofrer abuso.

- $\quad$ Aparência descuidada e suja pela relutância de trocar de roupa.

${ }^{281}$ DOS SANTOS; IPPOLITO; NEUMANN, (orgs). Op cit; p 45-49.

${ }^{282}$ Iden, Ibidem; p 47-49. 
- Resistência em participar de atividades físicas.

- $\quad$ Frequentes fugas de casa.

- $\quad$ Prática de delitos.

- Envolvimento em prostituição infantojuvenil.

- Uso e abuso de substâncias como o álcool, drogas

- Dificuldade de concentração e aprendizagem resultando em baixo rendimento escolar.

- Não participação ou pouca participação nas atividades escolares.

- Tendência ao isolamento social com poucas relações com colegas e companheiros.

Mesmo na literatura internacional há, ainda, raros dados específicos a respeito dos efeitos do abuso sexual on-line em crianças ${ }^{283}$. Somente um artigo é mencionado na extensa revisão de literatura a respeito do aliciamento on-line em que, expressamente, são apresentados achados de pesquisa feita com vítimas de "exploração sexual on-line" (termo original). Os resultados desses achados são comportamentos indicadores de violência sexual, e não diferem, em termos qualitativos, dos acima listados.

Segundo o estudo de WELLS e MITCHELL ${ }^{284}$, de 2007, 61\% dos clientes com menos de 18 anos que haviam sido vítimas de exploração sexual on-line tinham diagnósticos atuais que preenchiam os critérios de vários transtornos descritos no Manual estatístico e diagnóstico de transtornos mentais da Associação Americana de Psiquiatria.

No mesmo estudo, os pesquisadores encontraram que, dentre as clientes do sexo feminino que haviam sido vítimas de exploração sexual ${ }^{285}$, 101 tinham problemas relacionados a depressão (71\%), ansiedade ou fobias (45\%), situações de vida estressantes (34\%), ideação ou tentativa de suicídio (27\%), conflitos com os pais (83\%), problemas disciplinares em casa (47\%), isolamento social (35\%), dificuldade de fazer amigos (31\%),

${ }^{283} \mathrm{CHOO}$, op cit.

${ }^{284}$ WELLS M \& MITCHELL KJ 2007. Youth sexual exploitation on the internet: DSM-IV diagnoses and gender differences in co-occurring mental health issues. Child and adolescent social work journal 24(3): 235-260, apud CHOO, K R. op cit.; tradução livre da autora.

${ }^{285}$ Não há especificação se se trata de exploração sexual on-line; porém, o título do artigo (Youth sexual exploitation on the internet) leva a crer que somente casos de exploração sexual praticada por meio da internet foram examinados. 
notas ruins na escola (47\%), problemas disciplinares na escola (30\%), vitimização sexual (56\%) e comportamento sexualizado ("sexual acting out" $\left.{ }^{, 286}\right)(35 \%)$.

Dentre os 31 adolescentes do sexo masculino, vítimas de exploração sexual, 68\% foram diagnosticados com depressão, 55\% com ansiedade ou fobias, 45\% tinham situações de vida estressantes, $10 \%$ ideação ou tentativa de suicídio, $81 \%$ evidências de conflitos com os pais, $58 \%$ problemas disciplinares em casa, 39\% isolamento social , $29 \%$, dificuldade de fazer amigos, $35 \%$ fracasso escolar, $45 \%$ problemas disciplinares na escola, 55 tinham experimentado vitimização sexual, e $48 \%$ apresentavam comportamento sexualizado ("sexual acting out").

Apesar da precocidade dos estudos, não é de surpreender que as evidências apontem para a identificação de efeitos da violência sexual mediada pela TIC semelhantes aos efeitos da violência sexual presencial. Mais estudos são necessários, todavia, para que se possam estabelecer indicadores mais precisos, específicos para a situação da violência sexual on-line.

A importância da identificação dos danos reais e potenciais às crianças e adolescentes decorrentes da violência sexual mediada pela TIC reside não só no fato de que esta identificação proporciona a elaboração de políticas, programas, projetos e medidas eficazes pós-vitimização, com vistas a proteger as vítimas e a evitar sua revitimização (medidas de prevenção vitimal secundária e terciária) ${ }^{287}$, mas também tem uma aplicação em termos jurídico-penais, pois a correta identificação de tais resultados lesivos está relacionada à identificação do bem jurídico protegido pela norma penal e, consequentemente, às consequências para o autor do fato ${ }^{288}$.

\footnotetext{
286 A tradução da expressão é difícil. "Acting out" quer dizer, literamente, "agir para fora", ou seja, demonstrar, por ações, o que está na mente do indivíduo. Uma tradução comum, que foi aqui adotada, é "comportamento". Mais que uma expressão, porém, o "acting out" é um conceito psicanalítico complexo, que diz respeito a ações que expressam dificuldade em lidar com conflitos internos; a ação realizada pode ser autodestrutiva e inibir o desenvolvimento de respostas construtivas, ao invés de expressar os sentimentos de formas mais benéficas para o sujeito. Fonte: Wikipedia (http://en.wikipedia.org/wiki/Acting_out). No rol de indicadores transcrito acima, a expressão sexual acting out poderia corresponder às seguintes descrições: expressão de afeto sensualizada ou mesmo certo grau de provocação erótica, inapropriado para uma criança; Desenvolvimento de brincadeiras sexuais persistentes com amigos, animais e brinquedos; Masturbar-se compulsivamente; Abandono de comportamento infantil, de laços afetivos.

287 A respeito dos conceitos de prevenção primária, secundária e terciária, cf. Capítulo 5.

${ }^{288}$ Para a discussão a respeito do bem-jurídico na violência sexual contra crianças e adolescentes, remeto ao início deste mesmo capítulo.
} 


\section{Parte II - Direito da Criança e do Adolescente: participação e desenvolvimento}

Qualquer proposta de prevenção ligada às crianças e aos adolescentes precisa partir das suas realidades. É preciso, antes de tudo, olhar atentamente para esses seres humanos cujos direitos pretendemos garantir, e escutá-los com atenção. Se essas afirmações, hoje, podem não apresentar nenhuma novidade, só muito recentemente puderam ser formuladas sem causar espanto, a partir do reconhecimento de crianças e adolescentes como sujeitos de direitos.

Na formulação de estratégias de prevenção em nível individual ou coletivo, ouvir as crianças e adolescentes é fundamental. Considerando-se o objeto da presente pesquisa, é preciso considerar, ainda, o fato de que as vivências de crianças e adolescentes com a TIC são diferentes das dos adultos, em qualidade e quantidade. Não é possível - e nem aconselhável - pressupor que sabemos como é esta vivência. É preciso indagar diretamente a crianças e adolescentes o que vivenciam quando estão on-line; como se dão suas interações em redes sociais; que receios têm; como tomam a decisão de entrar ou não em um site que parece nocivo, baixar ou não um arquivo disponível on-line (download), aceitar ou não um novo amigo na rede social? E se algo acontecer, elas sabem o que fazer? A quem recorrem?

E se normalmente nos preocupamos somente com riscos, é preciso, ainda, indagar sobre os aspectos positivos de suas vivências no uso da TIC, buscando-se aproveitar as oportunidades prazerosas de interação para promover um comportamento mais consciente e, por consequência, mais seguro, para que possam fazer um uso saudável e criativo da tecnologia, de modo que a prevenção se apoie não somente em consciência de risco e estratégias de proteção, mas também na promoção dos pontos positivos da TIC, como a criação e manutenção de laços on e off-line (conforme mencionado no Capítulo 1 deste trabalho).

Situações de conflito eventualmente geradas pelo uso da tecnologia também requererão a participação ativa dos envolvidos na sua resolução, desde um conflito entre as próprias crianças e adolescentes (a prática de cyberbullying ou eventuais ofensas contra sua honra e imagem, pela divulgação de imagens íntimas via celular ou internet), até 
situações mais graves, como a apuração de práticas de aliciamento e exposição à pornografia infantil.

Por estas razões, considera-se fundamental, neste trabalho, um estudo do direito à participação, que abranja sua previsão legal, seu conteúdo e sua prática. Estes e outros aspectos do direito à participação serão desenvolvidos no Capítulo 3. No Capítulo 4, é apresentado o direito ao desenvolvimento e são exploradas suas conexões com a participação. Em um estudo interdisciplinar, parte-se da legalidade, dos princípios e direitos consubstanciados na CIDC, na CF 88 e no ECA, para discutir a sua razão de ser, que é apresentada a partir da psicanálise e da psicologia do desenvolvimento, e busco discutir algumas questões ligadas à sua prática.

Busca-se, aqui, caracterizar o que é ser criança e ser adolescente de modo mais genérico, sem o foco específico na relação desses sujeitos com a tecnologia, mas buscando entender como se dá o seu desenvolvimento, especialmente, sob o aspecto biopsicológico. ${ }^{289}$

Uma ressalva importante, já anteriormente feita e aqui repetida: se é possível inferir que a idade de início da puberdade talvez não tenha se alterado ao longo dos milênios ${ }^{290}$ (fator biológico que seria, portanto, universal), e que todas as crianças do mundo ingressam na fase operatório-concreta (descrita por PIAGET, adiante) por volta dos 7 ou 8 anos, sabe-se também que as transformações sociais têm significativo impacto na maneira como crianças e adolescentes vivem hoje. Em diferentes sociedades, diferentes tempos, diferentes culturas e locais, diferentes são as adolescências. No caso do Brasil,

\footnotetext{
${ }^{289}$ Tenho clareza que alguns dos conceitos e teorias que serão utilizadas para caracterizar a criança e o adolescente, apesar de terem sido, em parte, formulados com pretensões de serem aplicáveis a todos os seres humanos, têm limitações que se devem, no mínimo, ao momento histórico e à sociedade em que foram baseadas (é o caso da psicanálise e da teoria do desenvolvimento). Não seria possível, porém, realizar uma caracterização geral do que é ser criança e ser adolescente sem recorrer a teorias com esta pretensão, mesmo porque, após anos de aplicação nas mais diversas situações e contextos, no Brasil, já se mostraram adequadas para a compreensão de boa parte das questões do desenvolvimento infantojuvenil e são, com frequência, o ponto de partida de bem-sucedidas intervenções junto a crianças e adolescentes. Isso não exclui, obviamente, que outras teorias e interpretações possam ser utilizadas com igual eficácia, guardadas as devidas singularidades. A escolha dessas teorias deveu-se à sua reconhecida relevância, além da possibilidade de estabelecer um diálogo entre seus conceitos e os demais eixos de análise do presente trabalho.

${ }^{290}$ E talvez nem mesmo esta afirmação seja possível. Infelizmente, não há, no escopo deste trabalho, condições de verificar tal dado.
} 
essa constatação vai ainda mais longe: em diferentes estados da federação, as condições da infância e da adolescência podem mudar radicalmente.

Além disso, a tecnologia tem mais e mais adquirido centralidade nas vidas de milhares de crianças e adolescentes, e esta é uma tendência irreversível, mas que ainda se manifesta de modo desigual no Brasil e no mundo. Essas são questões que precisam ser levadas em conta na reflexão sobre estratégias de prevenção que se pretendam destinadas a crianças e adolescente que devem ter seus direitos igualmente garantidos.

Por fim, um esclarecimento sobre a opção metodológica utilizada nos dois capítulos que compõem esta segunda parte do trabalho: como acima asseverado, foi preciso que os direitos de crianças e adolescentes fossem reconhecidos na ordem jurídica internacional para que passassem a ser paulatinamente incorporados à ordem jurídica brasileira $^{291}$. O desenvolvimento científico, que permitiu a compreensão ${ }^{292}$ do que é ser criança e ser adolescente, se deu em paralelo a este processo de positivação de direitos - e se iniciou bem antes dele. Porém, foi a sua positivação nas ordens jurídicas internacional e nacional que abriu o caminho para que se pudesse exigir a elaboração e execução de políticas/programas/projetos e ações de proteção a crianças e adolescentes (ainda que esta positivação não esteja imune a críticas). Assim, é necessário identificar, com relação ao sujeito das políticas (o seu beneficiário), quais normativas internacionais e nacionais amparam a sua necessidade, e qual a razão de ser dessas normas ${ }^{293}$.

\footnotetext{
${ }^{291}$ Apesar de a CF 88 ter sido promulgada antes da CIDC, e de o ECA ter sido promulgado um ano após, foram as discussões em âmbito internacional, das quais o Brasil participou com relevância, acompanhadas por um movimento social pela afirmação dos direitos das crianças, que impulsionaram a redação do artigo 227 da CF 88 e a elaboração do ECA. Saliente-se, todavia, que isto não anula o ineditismo e a ousadia de inúmeros dispositivos do ECA, que por isso é uma legislação de referência internacional.

${ }^{292}$ Aliás, não houve só compreensão, mas também, até certo ponto, criação, em especial da categoria "adolescência", que não existia inicialmente.

${ }^{293}$ Também é preciso lembrar que este trabalho, apesar de interdisciplinar e fortemente baseado não só no Direito da Criança e do Adolescente, mas também nas Ciências Criminais, é desenvolvido no âmbito de um programa de pós-graduação em Direito, o que também justifica a opção de tomar a legalidade como ponto de partida.
} 


\section{Capítulo 3: Infância, adolescência e Participação: o direito de ser criança e de ser adolescente.}

Até o advento das primeiras legislações específicas de direito das crianças e dos adolescentes, a partir do final do século $\mathrm{XIX}^{294}$, sequer se cogitava demandar a sua inclusão em qualquer tipo de tomada de decisão a respeito de suas vidas (no caso das mulheres, essa incapacidade se estendia até a idade adulta, já que não podiam tomar decisões importantes mesmo depois de casadas). E mesmo após a entrada em vigor dos primeiros Códigos de Menores ${ }^{295}$, crianças e adolescentes eram tratados como objeto de tutela, sendo responsabilizados e/ou protegidos conforme a conveniência (e a consciência) do julgador e/ou de seus responsáveis.

Foram necessários, assim, quase 100 anos de legislações para crianças para que elas passassem a ter, por lei, o direito de ter sua opinião ouvida e considerada. A partir da Convenção Internacional sobre os Direitos da Criança (CIDC) e, internamente, da Constituição da República Federativa do Brasil de 1988 (CF88) e do Estatuto da Criança e do Adolescente (ECA, Lei no 8.069, de 13 de Julho de 1990), passa-se a garantir às crianças o direito à participação, compreendido, grosso modo, como o direito de manifestar sua opinião e de tê-la considerada, especialmente no tocante a decisões tomadas a seu respeito.

$\mathrm{Na}$ apreciação a respeito do direito à participação, tornou-se comum, dentre os pesquisadores e profissionais que atuam na área ou estudam as temáticas da infância e juventude, o uso dos termos "adultocêntrico" e "adultocentrismo" ${ }^{296}$. Assim como as

\footnotetext{
294 Até o final do século XIX, juridicamente, as crianças não recebiam qualquer tipo de tratamento diferenciado dos adultos. As primeiras jurisdições especializadas para crianças datam de 1899 (Estados Unidos), 1911 (Portugal), 1912 (França), 1918 (Espanha) e, na América latina, 1919 (Argentina) (cf, SHECAIRA, Sérgio Salomão. Sistema de garantias e o direito penal juvenil. São Paulo: Revista dos Tribunais, 2008, p. 34.

${ }^{295}$ No Brasil foram dois os Códigos de Menores, o primeiro (Decreto Federal 17.943, de 12 de outubro de 1927) conhecido como Código Mello Mattos, e o segundo em 1979 (Lei 6.697/79).

${ }^{296}$ Historiadores, como Mary DEL PRIORE identificam que, "diferentemente da história da criança feita no estrangeiro, a nossa não se distingue daquela dos adultos. Ela é feita, ao contrário, à sua sombra. (...) Foi a voz dos adultos que registrou, ou calou, sobre a existência dos pequenos (...)". DEL PRIORE, Mary. História das Crianças no Brasil. São Paulo: Contexto, 2006; p. 14. A respeito, confira-se, ainda, por exemplo, NOGUEIRA NETO, Wanderlino. Por uma Política Nacional de Garantia, Promoção e Proteção dos Direitos Humanos da Criança e do Adolescente In Democracia, direitos humanos e mediação de conflitos: do local ao internacional/Organização Valdênia Brito Monteiro.- Recife: Gajop, 2011, p. 22-75, p.
} 
feministas deixaram claro o quanto as leis, as políticas e as práticas eram (e ainda são, em grande medida) machistas ${ }^{297}$, tendo sido não só concebidas, escritas, e executadas por homens, mas, principalmente, tendo sido baseadas nos pontos de vista dos homens, os pesquisadores e profissionais da infância e juventude têm desvelado o quanto as construções de políticas, programas, projetos e ações para crianças têm sido baseadas no ponto de vista do adulto, desconsiderando a realidade da própria criança e seu ponto de vista.

Se isto era antes aceitável, atualmente não é mais. A partir do desenvolvimento científico, e das descobertas a respeito da psique humana e infanto-juvenil e a respeito do desenvolvimento humano; e, mais recentemente, a partir da positivação dos direitos de crianças e adolescentes e de seu reconhecimento como sujeitos de direitos, não é possível mais aceitar que ações, em qualquer nível, direcionadas às crianças e adolescentes, sejam construídas sem a sua participação e desconsiderando as peculiaridades de seu processo de desenvolvimento.

A partir da garantia formal do direito à participação, a inclusão das crianças como sujeitos ativos e capazes de manifestar sua opinião deixa de ser uma faculdade e passa a ser um direito, ao qual corresponde um dever dos atores do Sistema de Garantia de Direitos (SGD) da Criança e do Adolescente, de que fazem parte Família, Estado e Sociedade, conforme dispõe o art. 227 da CF88.

Apesar disso, somente recentemente passou-se a refletir e debater a respeito de seu conteúdo e a proporcionarem-se as primeiras oportunidades para o seu exercício. Ainda hoje, o conteúdo do direito à participação não é adequadamente compreendido e pouco colocado em prática.

29; ver, também, BRASIL. Presidência da República. Secretaria de Direitos Humanos. Secretaria Nacional de Promoção dos Direitos da Criança e do Adolescecente. Conselho Nacional dos Direitos da Criança e do Adolescente. Construindo a Política Nacional dos Direitos Humanos de Crianças e Adolescentes e o Plano Decenal dos Direitos Humanos de Crianças e Adolescentes 2011 - 2020: Documento Preliminar para Consulta Pública. $\quad$ Brasília, 2010.20 Disponível em http://portal.mj.gov.br/sedh/conanda/Politica\%20e\%20Plano\%20Decenal\%20consulta\%20publica\%2013\%2 0de\%20outubro.pdf.

297 Cf, por exemplo, SABADELL, A. L.;DIMOULIS, Dimitrios. Constitucionalidade, moralidade e tratamento penal do aborto com o consentimento da gestante. In: Ingo Wolfgang Sarlet; George Salomão Leite. (Org.). Direitos fundamentais e biotecnologia. São Paulo: Método, 2007, p. 325-349; também, da primeira autora, A problemática dos delitos sexuais numa perspectiva de direito comparado. Revista Brasileira de Ciências Criminais, São Paulo, v. 7, n. 27, p.80-102, jul./set. 1999. 
Uma das manifestações da falta de compreensão sobre o conteúdo do direito à participação se identifica a partir de comentários (de senso comum) dos adultos a respeito do ECA, considerado por muitos uma legislação permissiva, a partir da qual "agora não se pode mais fazer nada" com as crianças, já que "são elas que mandam em tudo". O ECA é visto como um instrumento de garantia de direitos para 'pequenos bandidos', 'menores infratores', e crianças e adolescentes desobedientes e rebeldes, que agora têm o direito de opinar, escolher e decidir, e que não podem mais apanhar.

Tome-se como exemplo análise realizada por Sônia Margarida Gomes SOUSA ${ }^{298}$ a partir de depoimentos prestados à Comissão Parlamentar de Inquérito (CPI) da Prostituição Infanto-Juvenil instaurada pela Câmara Federal entre os anos de 1993 e 1994.

Apoiada na revisão bibliográfica de diversos notórios pesquisadores das questões da infância no Brasil, como Mary DEL PRIORE e Irene RIZZINI, entre outros, a autora identifica que, embora o tema da CPI seja a prostituição infantil e juvenil, poucos depoentes se referiram diretamente à situação de vida das crianças e adolescentes, de modo que a infância/adolescência não aparece como conceito-chave na CPI. Ao invés disso, outros temas foram abordados, como pobreza, políticas públicas, família. "Esta atitude de aparente 'esquecimento' ou desconsideração, antes de ser uma atitude isolada e sem significado, na verdade parece refletir a posição de pouco destaque da infância/adolescência na sociedade brasileira"299.

SOUSA identifica quatro diversas concepções expressas na CPI a respeito das crianças e adolescentes: "moralista", "socioeconômica", "psicológica" e "funcional". Dentre os depoimentos transcritos, um deles, identificado como "moralista", expressa de modo solar as concepções do senso comum a respeito da infância/adolescência e do ECA supra referidas:

“[...] as crianças, hoje, sabem muito bem os ditames legais que as protegem. O que estas crianças não sabem, ilustre comissão,

\footnotetext{
${ }^{298}$ SOUSA, Sônia Margarida Gomes e SANTOS, Joseleno Vieira dos. "Exploração sexual de crianças e adolescentes: pesquisas com documentos de domínio público", Goiânia, Cânone, 2008.

${ }^{299}$ SOUSA, op. Cit., p. 99.
} 
é de suas responsabilidades. Deram às crianças a vã proteção e esqueceram de dar a elas trabalho." 300

As observações de SOUSA refletem considerações que Helena Wendel $\mathrm{ABRAMO}^{301}$ já fazia a respeito desde a década de 1990, incluindo a academia que, na sua análise, destinava a maior parte das reflexões à discussão dos "sistemas e instituições presentes nas vidas dos jovens (notadamente as instituições escolares, ou a família, ou ainda os sistemas jurídicos e penais, no caso de adolescentes em situação "anormal" ou de risco), ou mesmo as estruturas sociais que conformam situações "problemáticas" para os jovens, poucas delas enfocando o modo como os próprios jovens vivem e elaboram essas situações". [destaquei]

Também dialogando com estas ideias, VICENTIN aponta, em trabalho focado em adolescentes em conflito com a lei, o quanto persistem, ainda hoje, "as práticas autoritárias e violentas de que são objeto as crianças, com características singulares em cada formação sociohistórica. Mesmo em sociedades em que não está em jogo a sobrevivência e as condições de dignidade da vida das crianças, encontramos outra ordem de práticas em que persistem o adultocentrismo, o exercício da dominação e a codificação da criança numa infantilização que não é sua". 302

Estas autoras identificam, portanto, uma certa invisibilidade das crianças e adolescentes, não porque não sejam estudados, ou que não haja preocupação com eles, mas porque não se pergunta a eles, em momento algum, afinal, quem são, quais são as

\footnotetext{
300 Idem, p. 102. Este é apenas um pequeno trecho deste depoimento, que teve ainda outras partes igualmente emblemáticas transcritas pela autora.

301 "De forma geral, e a grosso modo, pode-se notar uma divisão nestes dois diferentes modos de tematização dos jovens nos meios de comunicação. No caso dos produtos diretamente dirigidos a esse público, os temas normalmente são cultura e comportamento: música, moda, estilo de vida e estilo de aparecimento, esporte, lazer. Quando os jovens são assunto dos cadernos destinados aos "adultos", no noticiário, em matérias analíticas e editoriais, os temas mais comuns são aqueles relacionados aos "problemas sociais", como violência, crime, exploração sexual, drogadição, ou as medidas para dirimir ou combater tais problemas". A grosso modo, no entanto, pode-se dizer que a maior parte desses programas [desenvolvidos por instituições e agências de trabalho social] está centrado na busca de enfrentamento dos "problemas sociais" que afetam a juventude (cuja causa ou culpa se localiza na família, na sociedade ou no próprio jovem, dependendo do caso e da interpretação), mas, no fundo, tomando os jovens eles próprios como problemas sobre os quais é necessário intervir, para salvá-los e reintegrá-los à ordem social." ABRAMO, Helena Wendel. Considerações sobre a tematização social da juventude no Brasil. Revista Brasileira de Educação. Rio de Janeiro, n. 5-6, p. 25-36, dez., 1997, p. 5-6. No mesmo sentido, ENDO, Paulo. Criação e Destruição. In Revista Viver Mente \& Cérebro, O Olhar Adolescente, Vol. 4 - Espelhos da Sociedade. São Paulo: Duetto. p. 62-69.

${ }^{302}$ VICENTIN, Maria Cristina. A vida em rebelião: historias de jovens em conflito com a lei. Tese (Doutorado em Psicologia Clínica). São Paulo: Pontifícia Universidade Católica de São Paulo, 2002; introd.
} 
suas vivências e seus problemas. Embora presentes nas discussões políticas, na academia, ao analisar-se detidamente as práticas e discursos, percebe-se a sua ausência.

Esquecemo-nos, com frequência, de incluir crianças e adolescentes nos processos decisórios que lhes dizem respeito. Outras vezes, lembramo-nos, mas justificamos a sua não inclusão a partir dos tradicionais estereótipos que rondam esses novos sujeitos de direito: não sabem o que é certo ou errado, precisam ser guiadas, são impulsivas, não têm maturidade para decidir ${ }^{303}$.

Os adolescentes percebem claramente a dicotomia entre o reconhecimento jurídico da participação e a sua prática efetiva:

\begin{abstract}
"No papel, está lindo, o direito do adolescente a se expressar. Mas, na prática, acham que o adolescente não tem nada de útil, que não tem nada de bom para oferecer. Na verdade, a gente tem muito a contribuir. Apesar da pouca experiência e idade, nós vivemos muito e de tudo um pouco, e tentamos encaixar as vivências e experiências em qualquer situação.” Diego Gomes de Moraes, 17 anos, Heliópolis - SP ${ }^{304}$
\end{abstract}

Neste diapasão, ABRAMO identifica que, apesar de haver uma queixa dos atores políticos a respeito da distância que os jovens têm demonstrado para com as suas proposições, bandeiras e formas de atuação, na verdade, essa queixa reflete, "em primeiro plano, uma preocupação com a renovação de quadros no interior dessas organizações, mais do que em tratar e incorporar temas levantados pelos próprios jovens. Essa preocupação vem acompanhada de um diagnóstico que identifica nos jovens um desinteresse pela política e de um modo mais geral pelas questões sociais, como resultado da acentuação do individualismo e do pragmatismo que se afirmam como tendências sociais crescentes, tornando-os "pré-políticos" ou quase que inevitavelmente "apolíticos" ${ }^{305}$. [destaquei] O diagnóstico serve, assim, como justificativa para uma

\footnotetext{
${ }^{303}$ Argumentos parecidos eram utilizados, até a década de 70 do século XX, para justificar a exclusão feminina das decisões sobre a própria vida e da participação política, entre outros.

${ }^{304}$ UNICEF. O direito de ser adolescente..., p. 20.

${ }^{305}$ ABRAMO, op. cit., p. 27. Considerações sobre a questão da participação dos adolescentes na política serão feitas mais adiante, neste mesmo capítulo.
} 
exclusão - ou para uma inclusão que é feita somente na aparência, já que não se preocupa, de fato, em ouvir o que os jovens têm a dizer.

Não por acaso, estas justificativas coadunam-se perfeitamente com a antiga Doutrina da Situação Irregular (do Direito do Menor), que abordava as questões da infância de modo "meramente filantrópico-caritativo", pautada por "ações que se configuravam como uma benesse ou favor do mundo adulto, apaziguando consciências e legitimando o higienismo dominante - uma linha castradoramente "tutelar", portanto, adultocêntrica" ${ }^{306}$.

Promover uma participação meramente formal é fácil. Basta juntar crianças e adolescentes em uma sala e dar-lhes instruções bastante precisas sobre como e o que fazer. Já treinadas pelas escolas, cujos métodos de ensino ainda são baseados na hierarquia, no poder e na atitude passiva de ouvir o mestre e decorar o que ele "ensinou", crianças e adolescentes, rapidamente executam aquilo que esperamos. Fazem lindos cartazes, repetem discursos ensaiados ${ }^{307}$. Emocionados, somos tomados por um sentimento de autoapreciação por termos lhes dado a oportunidade de se expressarem. Batemos palma e saímos do local com a consciência tranquila: cumprimos a nossa missão! Fotografias são tiradas para que, orgulhosamente, mostremos em nossos relatórios de projeto que as decisões foram tomadas de maneira participativa.

\footnotetext{
${ }^{306}$ NOGUEIRA NETO, Wanderlino. Por uma Política Nacional de Garantia, Promoção e Proteção dos Direitos Humanos da Criança e do Adolescente In Democracia, direitos humanos e mediação de conflitos: do local ao internacional/Organização Valdênia Brito Monteiro.- Recife: Gajop, 2011, p. 22-75, p. 29.

${ }^{307}$ É possível identificar claramente quando há participação real ou ensaiada em diferentes grupos de crianças. Presenciei mais de uma vez, durante a execução do Programa CPP, numa mesma reunião, grupos de crianças que participam de programas de atendimento em horário complementar à escola em diferentes instituições. As crianças de uma dessas instituições, com frequência, tinham sua plena participação tolhida pelos adultos, que direcionavam ou filtravam suas respostas em trabalhos coletivos e treinavam-nas, de modo que as apresentações fossem coerentes e bonitas. E eram, mas soavam, sempre, um pouco falsas. Uma 'pulga' permanecia 'atrás da orelha' enquanto assistia os adolescentes, comunicativos e expressivos, contarem suas histórias ou darem suas opiniões. A diferença entre este grupo e o grupo das crianças de outra instituição era notável. As apresentações e respostas das crianças do segundo grupo não eram tão organizadas, coerentes e perfeitas. Havia muito de improviso, um pouco de agitação, risadas fora de hora, espontaneidade, certa vergonha por falar em público. Mas eram, claramente, respostas dadas por crianças. Facilitadas, sim, pelos adultos, mas sua autenticidade era evidente. Com isso, não quero dizer que não haja valor em promover alguma participação. Era claro, nos dois grupos, o quanto estar no meio de adultos debatendo as mesmas questões, em igualdade, tinha sua importância e era excitante para todas as crianças. Mas a diferença qualitativa da participação era visível, e desvelava muito sobre as instituições e suas práticas, colocando em xeque, inclusive, os resultados que costumam apresentar à sociedade (e, em última instância, influenciando os próprios resultados do programa CPP).
} 
A real participação, porém, não é de fácil concretização. É trabalhosa, requer vontade, tempo, atenção, escuta, paciência e tolerância (com as crianças, com o processo e consigo próprio!). Requer revisão de preconceitos; requer adaptação de conceitos, da linguagem, do método, para que sejam adequados às crianças. Até mesmo entre grupos de crianças da mesma idade podem ser necessárias adaptações que levam em conta sua realidade, sua condição social.

É evidente que crianças e adolescentes precisam dos adultos para guiá-las no exercício deste direito (assim como no de tantos outros), necessidade esta que vai, progressivamente, sendo menos e menos importante conforme desenvolvem a capacidade de pensar, articular, fazer associações, inferências, ponderar prós e contras, tomar decisões etc. Cabe dizer, porém, que o papel do adulto, neste processo, é o de oportunizar e facilitar a participação, e não decidir e falar pela criança ou pelo adolescente, baseado no que ele, adulto, pensa que elas queriam dizer ou no que gostaria que elas dissessem.

Alguma participação, porém, ainda parece melhor que nenhuma participação. A possibilidade de protagonizar, de ter a atenção dos adultos e de seus pares para sua fala, sua expressão, ainda que por alguns minutos, já é algo que, para muitas crianças, pode significar a diferença entre ser considerado invisível ou digno de valor. Não podemos nos contentar com isso, porém.

É que, como se verá, a participação tem papel relevantíssimo no desenvolvimento da criança e do adolescente.

Ademais, sua garantia abrange uma série de aspectos, que podem ser resumidos (sem ser limitar a) no direito das crianças e adolescentes de serem ouvidos e terem suas opiniões consideradas. Este é o cerne do direito à participação, conforme se verá a seguir. Este direito, que se harmoniza com os demais princípios centrais do ECA (igualdade, prioridade absoluta, proteção integral, condição de pessoa em desenvolvimento) estendese não só à sua participação na vida cotidiana privada, de forma individual ou coletiva (junto à família, à escola e à comunidade), mas também à formulação e execução de políticas públicas, nas três esferas de governo e nos três poderes que compõem o Estado. 


\title{
3.1. A participação de crianças e adolescentes na esfera jurídica internacional e nacional
}

$\mathrm{O}$ direito à participação encontra-se reconhecido tanto na CIDC quanto na legislação brasileira (ECA e Constituição Federal de 1988).

Apesar de amplamente reconhecido na comunidade internacional como um dos mais importantes direitos consubstanciados na convenção, o termo é pouco utilizado no meio jurídico, quase inexistente em doutrinas brasileiras a respeito do direito da criança e do adolescente ${ }^{308}$.

É o artigo 12 da CIDC considerado o coração de uma série de artigos que compõem, juntos, este o direito à participação.

\begin{abstract}
“Artigo 12:
1. Os Estados Partes garantem à criança com capacidade de discernimento o direito de exprimir livremente a sua opinião sobre as questões que lhe respeitem, sendo devidamente tomadas em consideração as opiniões da criança, de acordo com a sua idade e maturidade.
\end{abstract}

2. Para este fim, é assegurada à criança a oportunidade de ser ouvida nos processos judiciais e administrativos que lhe respeitem, seja diretamente, seja através de representante ou de organismo adequado, segundo as modalidades previstas pelas regras de processo da legislação nacional ${ }^{1309}$

O artigo 12, todavia, não esgota o rol dos direitos consubstanciados na convenção que integram a participação. Incluem-se na interpretação do que compõ $\mathrm{e}^{310} \mathrm{o}$ direito à participação a liberdade de expressão e de consciência, pensamento e religião (artigos 13 e 14 da CIDC), o direito à liberdade de associação (art. 15), o direito de não ser separado de

\footnotetext{
${ }^{308}$ Em pesquisas por bibliografia realizadas com o uso da palavra-chave participação, escassos trabalhos mencionam o referido direito; na maioria dos casos, são assinados por pesquisadores de áreas diversas do direito.

${ }^{309}$ UNICEF. A Convenção sobre os Direitos da Criança: Adoptada pela Assembleia Geral nas Nações Unidas em 20 de Novembro de 1989 e ratificada por Portugal em 21 de Setembro de 1990. Disponível em http://www.unicef.pt/docs/pdf_publicacoes/convencao_direitos_crianca2004.pdf; p. 10.

310 LANSDOWN, Gerison. Promoting Children's Participation In Democratic Decision-Making. UNICEF/Innocenti Research Centre: Florence, 2001; p. 7.
} 
sua família sem a consideração de seu ponto de vista (art. 9); o direito de ser ouvida e ter sua opinião levada a sério (art. 12), o direito à privacidade (art. 16); o direito à informação (art. 17); o direito a uma educação promotora do desenvolvimento e do respeito aos direitos humanos (art. 29) e, finalmente, o direito ao desenvolvimento (arts. $5^{\circ}$ e $6^{\circ}$ ).

A participação é, ainda, referenciada ${ }^{311}$ nos artigos 21 a), que faz referência ao consentimento nos processo de adoção, por todos os interessados (incluindo-se, portanto, a criança), no artigo 37 , que outorga a toda criança privada de liberdade 312 o direito a impugnar a legalidade desta medida perante um tribunal, o que implica no direito a ser ouvido, e no artigo 40.2 b), iv, em que se garante a participação ativa da criança acusada de infração das leis penais nos procedimentos (sem que isso implique na obrigação de se auto-acusar).

Cabem, inicialmente, algumas considerações, amparadas em comentário das próprias Nações Unidas a respeito do artigo 12 da CIDC $^{313}$. Em primeiro lugar, nota-se que o artigo 12 estabelece uma obrigação, e não uma faculdade ao Estado-parte ("os Estadospartes garantem..."). O destaque se torna mais importante ao examinar a locução do texto original da CIDC, "shall assure", que poderia gerar a impressão de que se trata de uma faculdade. Esta obrigação implica na tomada de medidas concretas e apropriadas para a completa implementação deste direito, para todas as crianças.

Segundo o artigo 12, o direito a expressar sua opinião é garantido "à criança com capacidade de discernimento". A tradução oficial da locução não foi feliz. A tradução literal do texto original em inglês significa que à opinião da criança deve ser "dado o devido peso de acordo com a idade e maturidade da criança" ("being given due weight in accordance with the age and maturity of the child"). Nota-se que a locução "com capacidade de discernimento", pela qual se optou na tradução oficial, limita o âmbito de

\footnotetext{
${ }^{311}$ HODGKIN, Rachel; NEWELL, Peter. Manual de Aplicación de la Convención sobre Los Derechos del Niño. Edición española enteramente revisada. UNICEF, 2004. Disponível em http://www.unicef.org/spanish/publications/index_5598.html.

${ }^{312}$ Vale lembrar que o termo criança, quando usado na CIDC, significa pessoa até 18 anos de idade, englobando, portanto, os adolescentes.

${ }^{313}$ UNITED NATIONS. Committee on the Rights of the Child. Convention on the Rights of the Child. General Comment no. 12: The right of the child to be heard. Fifty-first session; Geneva, 25 may-12 june, 2009. Disponível em http://www2.ohchr.org/english/bodies/crc/comments.htm, consulta em 18.01.2012. Os comentários gerais são documentos elaborados pelas Nações Unidas com interpretações jurídicas e recomendações para orientar os Estados-parte na implementação da CIDC.
} 
aplicação do dispositivo, pois faz parecer que, se considerar que a criança "não tem capacidade de discernimento", a sua oitiva não é necessária.

Assim, ao determinar que o direito de ser ouvida é garantido à criança [e adolescente] "com capacidade de discernimento", não se está estabelecendo uma limitação (que, simplesmente, desobrigaria o Estado-parte de cumprir a determinação quando julgasse conveniente, desde que se declarasse, simplesmente, que a criança ou adolescente não tem capacidade de discernimento), mas como uma obrigação do Estado-parte em avaliar, da maneira mais ampla possível, a capacidade da criança de emitir uma opinião autônoma.

Ou seja, a fixação legal de uma idade (por exemplo, 12 anos) não é critério suficiente para a decisão de ouvir ou não uma criança, e de considerar a sua opinião. "Os níveis de compreensão das crianças não são ligados à sua idade biológica de modo uniforme. Pesquisas demonstram que informação, experiência, ambiente, expectativas culturais e sociais e níveis de apoio contribuem para o desenvolvimento da capacidade da criança de formar uma opinião"314. Por fim, "quanto maior o impacto do resultado na vida da criança, mais relevante é a avaliação apropriada da maturidade da criança" ${ }^{315}$.

Enquanto, como se verá, o ECA diferencia situações em que crianças e adolescentes devem, necessariamente, consentir, enquanto que em outras o que se garante é somente direito de ser ouvido e ter sua opinião considerada, a CIDC não estabelece tal diferença. O que se entende, porém, é que a idade da criança ou sua eventual dificuldade em expressar-se não pode ser utilizada como desculpa para que não se façam esforços para ouvir sua opinião.

É fato, e isso assume especial relevância quando se trata de oitiva de crianças e adolescentes em processos ou procedimentos para apuração de casos de violência sexual, que muitas vezes a criança tem dificuldades para se expressar, seja pela tenra idade, seja por deficiência, inibição ou medo (no caso da violência sexual, muitas vezes o silêncio da criança está ligado à relação de segredo que se estabelece entre ela e o autor de violência sexual, chamada de "síndrome do segredo"). Para tanto, técnicas e práticas, denominadas

\footnotetext{
${ }^{314}$ UNITED NATIONS. Op. cit; p.11. Tradução livre da autora.

${ }^{315}$ Idem, ibidem.
} 
de depoimento especial, têm sido desenvolvidas e aperfeiçoadas no mundo todo ${ }^{316}$, buscando-se assegurar que a criança possa ser ouvida com respeito e dignidade e na tentativa de evitar sua revitimização.

A leitura da CIDC indica, contudo, que a garantia de um ambiente tranquilo e livre das pressões de adultos, e o oferecimento, à criança, de ambiente e formas amigáveis de expressão de sua opinião são necessários não só nos casos em que a criança é vítima de violência ou tem seus direitos violados, mas sempre que ela for chamada a participar. Dáse atenção especial, conforme a segunda parte do mesmo artigo $12^{317}$, às situações de envolvimento de crianças em processos judiciais, sendo que, atualmente, vem se formando, gradativamente, entendimento de que toda oitiva de criança ou adolescente deveria ser feita de forma a protegê-lo da violência que, quase naturalmente, cerca os procedimentos judiciais, sejam eles de competência da justiça criminal ou não.

É evidente que o artigo 12 não se traduz em obrigação da criança em expressar sua opinião, mas em direito, que a criança deve poder exercer livremente. Isto significa que, ao exercer a participação, a criança deve poder fazê-lo livre de pressão, coação ou influência ${ }^{318}$, e expressar a sua verdadeira opinião, e não a que lhe tenha sido incutida por outrem.

Para a garantia dessa liberdade de expressão e opinião, pode ser necessário, como já acima afirmado, oferecer à criança um ambiente acolhedor, onde ela sinta-se segura para se expressar. Além disso, deve-se evitar a oitiva reiterada de crianças em procedimentos que possam causar stress (como processos judiciais) ou que tenham potencial revitimizador.

\footnotetext{
${ }^{316}$ Conhecidas também como "depoimento sem dano", “depoimento sem medo", e "escuta/depoimento protegido", entre outras denominações. Na coleta do depoimento, são oferecidas à criança diversas formas para se expressar, que podem incluir brinquedos (no caso da violência sexual, bonecas e bonecos, em geral de pano, que têm os órgãos sexuais claramente representados), papel e lápis para desenhar etc. Cf, DOS SANTOS, Benedito Rodrigues; GONÇALVES, Itamar Batista. Depoimento sem medo(?):culturas e práticas não revitimizantes. ABMP, Childhood-Brasil. Secretaria Especial dos Direitos Humanos da Presidência da República (SEDH) e do Conselho Nacional dos Direitos da Criança e do Adolescente (Conanda). Disponível em http://www.cedeps.com.br/wp-content/uploads/2009/08/Livro_DepoimentoSemMedo_compact.pdf; CEZAR, José Antônio Daltoé. Depoimento sem Dano: Uma alternativa para inquirir crianças e adolescentes nos processos judiciais. Porto Alegre: Livraria do Advogado Editora, 2007.

317 “(...) é assegurada à criança a oportunidade de ser ouvida nos processos judiciais e administrativos que lhe respeitem, seja diretamente, seja através de representante ou de organismo adequado, segundo as modalidades previstas pelas regras de processo da legislação nacional". UNICEF. A Convenção sobre os Direitos da Criança.

${ }^{318}$ UNITED NATIONS, op. cit, p. 10.
} 
Vale dizer, ainda, que o direito à informação adequada acompanha a garantia desta liberdade. Para poder livremente expressar-se sobre um assunto, é preciso que a criança seja informada sobre as questões envolvidas, opções e possíveis decisões a serem tomadas e respectivas consequências. Obviamente que quantidade e profundidade de tais informações deverão ser dosadas de maneira adequada à idade da criança. Isso não significa, também, que a criança deverá tomar decisões que cabe aos adultos tomar. Em muitos casos, a tomada de decisão não é adequada e só causa na criança stress e sentimento de culpa. O que se deve garantir, nesses casos, é o direito de se manifestar, mas não, necessariamente, o direito de decidir. Essas peculiaridades deverão ser examinadas caso a caso ${ }^{319}$.

O direito de manifestar a opinião é garantido à criança em todas as questões que lhe digam respeito. Esta locução (em inglês, "in all matters affecting the child", cuja tradução literal é 'em todos os assuntos que afetem a criança') delimita o âmbito de aplicação do direito à participação, mas não deve ser interpretada de modo restrito. Por alguma razão, na tradução oficial, a palavra todos foi suprimida, o que reduz a interpretação do dispositivo.

A locução deve ser compreendida em sentido amplo. Isso significa tanto o dever de ouvir uma criança em particular quando decisões específicas forem tomadas a seu respeito (como nos processos judiciais que lhe digam respeito ${ }^{320}$, conforme teor do próprio artigo 12, e em outras decisões cotidianas tomadas no âmbito familiar, escolar, social), quanto o dever de ouvir as crianças, de modo amplo, com relação a assuntos que digam respeito a uma coletividade de crianças (na escola, por exemplo), ou que afetem todas as crianças de uma comunidade, município, estado ou Nação.

Não há uma lista, portanto, em que se delimitem quais são as oportunidades de participação da criança. Com o devido bom senso, sempre que for adequado, deve-se

\footnotetext{
${ }^{319}$ Um exemplo é a situação da criança cujos pais estão se divorciando, nas situações em que há disputa pela guarda. Deixar que a criança decida com qual dos pais quer ficar nem sempre será adequado (e, menos ainda, obrigá-la a decidir ou a dizer). Mas deve-se ouvi-la atentamente, inclusive fazendo uso de perícia psicológica, se o caso, antes da tomada da decisão. Em muitas situações, a criança poderá manifestar, explicitamente, o desejo de morar com um ou outro. Esta opinião é absolutamente relevante e deverá ser considerada seriamente pelo Juiz. No caso do adolescente isso se torna ainda mais relevante, já que ele tem a garantia do direito de ir e vir sem a companhia de responsáveis, colocando em questão as determinações do Judiciário e de seus pais.

${ }^{320}$ Aqui reitera-se a necessidade de se prover ambiente e condições adequados para esta oitiva.
} 
oportunizar a participação ${ }^{321}$. Para melhor compreensão, este dispositivo deve ser interpretado em consonância com os demais direitos assegurados à criança. Somado, por exemplo, à garantia da participação na vida política, o direito de ser ouvida amplia-se para as tomadas de decisões políticas que envolvam as crianças, em todas as instâncias e esferas de governo.

Feitas as considerações a respeito do direito à participação na CIDC, passemos à legislação brasileira.

Como já dito, a CF 88 reconhece o direito à participação por meio da garantia do direito à liberdade que será, posteriormente, especificado no ECA. Outras previsões que dizem respeito ao direito à participação encontram-se no $\S 3^{\circ}$ do artigo 227 que, em seu inciso IV, garante o "pleno e formal conhecimento da atribuição de ato infracional, igualdade na relação processual e defesa técnica por profissional habilitado" ao adolescente acusado de sua prática, tornando-o, assim, participante ativo de seu processo, e, no inciso $\mathrm{V}$, estabelece a "obediência aos princípios de brevidade, excepcionalidade e respeito à condição peculiar de pessoa em desenvolvimento, quando da aplicação de qualquer medida privativa da liberdade”. Neste último dispositivo, representa particular interesse a determinação do respeito à condição peculiar de pessoa em desenvolvimento, já que a participação é integrante essencial do direito ao desenvolvimento, e o respeito a essa condição, ao final, implica na necessidade da participação.

O $\S 7^{\circ}$ do mesmo artigo 227 remete ao artigo 204 da CF, que deverá ser considerado "no atendimento dos direitos da criança e do adolescente". O artigo 204, por sua vez, estabelece, como uma das diretrizes para organização das "ações governamentais na área da assistência social”, a "II - participação da população, por meio de organizações representativas, na formulação das políticas e no controle das ações em todos os níveis”.

\footnotetext{
${ }^{321}$ Conforme o Manual de Aplicação da Convenção, “en esencia, se afirma que el niño es una persona completamente desarrollada que tiene derecho a expresar su opinión libremente en todos los asuntos que lo afectan, así como a que se tengan debidamente en cuenta sus opiniones. Así pues, el niño tiene el derecho de participar en los procesos de toma de decisiones que afecten a su vida, así como de ejercer su influencia en las decisiones que se tomen a su respecto. Convención, y coexistan de forma autónoma, debe interpretarse en el sentido de que mientras que en el artículo 13 se reconoce de manera general la libertad de expresión, el artículo 12 incumbe a todos los casos en los que los asuntos en juego afecten al niño, destacando el derecho del niño a ser escuchado y a que SUS opiniones sean tenidas debidamente en cuenta." HODGKIN, Rachel; NEWELL, Peter; op cit; p. 460.
} 
A participação da criança e do adolescente na formulação da política não foi expressamente reconhecida pela CF88, mas a interpretação conjunta dos artigos 227 e 204 leva ao reconhecimento de sua garantia constitucional, conforme acima.

No ECA, o direito à participação não foi, explicitamente, reconhecido no rol dos direitos do artigo $4^{0322}$, mas veio incorporado em diversos artigos esparsos, refletindo a conformação da convenção internacional. Como se verá, o conteúdo do Estatuto não diverge da CIDC.

O artigo 16 do mesmo diploma legal estabelece, desde 1990, que o direito à liberdade compreende diversos aspectos: a liberdade de ir, vir e ficar, a liberdade de opinião e de expressão, a liberdade de crença e culto religioso, a liberdade de brincar, praticar esportes e divertir-se; a liberdade de participar da vida familiar e comunitária, sem discriminação; a liberdade de participar da vida política, na forma da lei; e a liberdade de buscar refúgio, auxílio e orientação.

Desde a sua promulgação, dispõe o Estatuto que a oitiva prévia de crianças e adolescentes é necessária em caso de colocação em família substituta ${ }^{323}$, sendo que no caso de adolescente a ser adotado, garante-se, desde então, não só a sua oitiva, mas é considerado necessário seu consentimento prévio $^{324}$.

A Lei n 12.010, de 2009 deu nova redação a uma série de dispositivos do Estatuto, reforçando, em inúmeros deles, o direito à participação. O parágrafo primeiro do artigo 28 , reformulado, estabelece não só a necessidade de ouvir criança e adolescente sempre que possível, mas oferece parâmetros mínimos para a realização desta oitiva, como a necessidade de que seja feita por "equipe interprofissional, respeitado seu estágio de desenvolvimento e grau de compreensão sobre as implicações da medida." Aliás, se a redação anterior deixava dúvidas a respeito da consideração ou não da opinião manifestada pela criança ("sempre que possível, a criança ou adolescente deverá ser

322 “Art. $4^{\circ}$ É dever da família, da comunidade, da sociedade em geral e do poder público assegurar, com absoluta prioridade, a efetivação dos direitos referentes à vida, à saúde, à alimentação, à educação, ao esporte, ao lazer, à profissionalização, à cultura, à dignidade, ao respeito, à liberdade e à convivência familiar e comunitária."

${ }_{323}^{323}$ Sob a forma de guarda, tutela ou adoção (ECA, art 28).

${ }^{324}$ A previsão do artigo $45, \S 2^{\circ}$, ainda em vigor, é de que "em se tratando de adotando maior de 12 (doze) anos de idade, será também necessário seu consentimento." $\mathrm{O} \S 1^{\circ}$ do artigo 28 , por sua vez, na redação original, determinava que, nos casos de guarda, tutela ou adoção, "sempre que possível, a criança ou adolescente deverá ser previamente ouvido e a sua opinião devidamente considerada.“ 
previamente ouvido e a sua opinião devidamente considerada"), a atual determinação legal é clara: a criança ou o adolescente "terá sua opinião devidamente considerada". Estabelece, portanto, um mandamento ao juiz, que tem não a faculdade, mas o dever de considerar a opinião da criança ou do adolescente ouvido ${ }^{325}$.

Além disso, a nova redação estende a necessidade de consentimento prévio do adolescente a todos os casos de colocação em família substituta, quando antes o previa somente para a situação de adoção.

Mais adiante, no artigo 53, o ECA reconhece o direito à educação, sendo que o primordial objetivo da educação, é o pleno desenvolvimento de crianças e adolescentes. Para efetivar o direito à educação, devem ser assegurados, ainda conforme o mesmo artigo, dentre outros, o "direito de organização e participação em entidades estudantis" ${ }^{326}$, outra expressão do direito à participação.

O recém reformado artigo 100 do Estatuto, que, por obra da mesma Lei 12.010/09, passou a ter um parágrafo único no qual se estabelecem princípios claros para a aplicação de medidas protetivas e socioeducativas (cf. art. 113), sendo um deles a participação:

Art. 100. Na aplicação das medidas levar-se-ão em conta as necessidades pedagógicas, preferindo-se aquelas que visem ao fortalecimento dos vínculos familiares e comunitários.

Parágrafo único. São também princípios que regem a aplicação das medidas:

325 Art. 28. A colocação em família substituta far-se-á mediante guarda, tutela ou adoção, independentemente da situação jurídica da criança ou adolescente, nos termos desta Lei.

$\S 1$ lo Sempre que possível, a criança ou o adolescente será previamente ouvido por equipe interprofissional, respeitado seu estágio de desenvolvimento e grau de compreensão sobre as implicações da medida, e terá sua opinião devidamente considerada. (Redação dada pela Lei no 12.010 , de 2009) Vigência

§ 2o Tratando-se de maior de 12 (doze) anos de idade, será necessário seu consentimento, colhido em audiência.

${ }^{326}$ Art. 53. A criança e o adolescente têm direito à educação, visando ao pleno desenvolvimento de sua pessoa, preparo para o exercício da cidadania e qualificação para o trabalho, assegurando-se-lhes:

I - igualdade de condições para o acesso e permanência na escola;

II - direito de ser respeitado por seus educadores;

III - direito de contestar critérios avaliativos, podendo recorrer às instâncias escolares superiores;

IV - direito de organização e participação em entidades estudantis

$\mathrm{V}$ - acesso à escola pública e gratuita próxima de sua residência. 
XII - oitiva obrigatória e participação: a criança e o adolescente, em separado ou na companhia dos pais, de responsável ou de pessoa por si indicada, bem como os seus pais ou responsável, têm direito a ser ouvidos e a participar nos atos e na definição da medida de promoção dos direitos e de proteção, sendo sua opinião devidamente considerada pela autoridade judiciária competente, observado o disposto nos $\S \S 10 \mathrm{e}$ 20 do art. 28 desta Lei. (Incluído pela Lei $n^{\circ}$ 12.010, de 2009) [destaquei]

Outros dispositivos do ECA que dizem respeito ao direito à participação são o art. 111, que assegura ao adolescente o pleno e formal conhecimento da atribuição de ato infracional e o direito de ser ouvido pessoalmente pela autoridade competente, entre outros; o ar. 124, que garante ao adolescente privado de liberdade, entre outros, o direito de petição direta a autoridade e o direito à informação sobre sua situação processual; o art. $161 \S 3^{\circ}$, que obriga, em procedimento judicial de perda e suspensão do poder familiar, desde que possível e razoável, à oitiva da criança ou adolescente, "respeitado seu estágio de desenvolvimento e grau de compreensão sobre as implicações da medida"; e, finalmente ${ }^{327}$, o art. 168, que, ao tratar do procedimento judicial para colocação em família substituta, determina que a criança/adolescente seja ouvida no procedimento, sempre que possível.

Nota-se, portanto, que o cerne do direito à participação, conforme consubstanciado no ECA, está nos direitos de liberdade (art. 16) e na previsão de oitiva da criança e do adolescente em processos judiciais de guarda/tutela/adoção (artigos 28 e 45), de imposição de medidas socioeducativas (art. 113 cc art 100, XII) e de aplicação de medidas protetivas (art. 100, XII). Talvez por esta razão, costuma-se interpretar tal direito de maneira bastante restrita.

Por isso, explicitar o conteúdo do direito à participação e as formas pelas quais se garante o seu exercício tem real importância. Não há, ainda, um claro e disseminado entendimento sobre o conteúdo de tal direito dentre profissionais que atuam na área da

\footnotetext{
${ }^{327}$ Pode haver outros dispositivos no ECA que digam respeito à participação e que possam ser integrados a este direito . Não é a intenção aqui esgotar essa lista, tratando-se de rol exemplificativo.
} 
infância, sem falar nas famílias e nas próprias crianças. ${ }^{328}$. A apropriação do conteúdo deste direito é recente, especialmente no tocante à questão da participação na vida política.

Enquanto o ECA é claro quando dispõe sobre o direito a ser ouvido pela autoridade no tocante a processos do interesse da criança (como nos casos já mencionados da adoção, da imposição de medida socioeducativa etc), o que torna a interpretação da norma bastante uniforme pela doutrina jurídica brasileira especializada, o reconhecimento da participação na vida política pode ser interpretado de maneira bastante limitada. José Afonso da SILVA, por exemplo, ao interpretar o artigo $16, \mathrm{~V}_{\text {do }} \mathrm{ECA}^{329}$ entendeu que

\begin{abstract}
"em sentido típico, essa liberdade realiza-se pelo exercício de atividades políticas (...) como filiação eleitoral e partidária, direito de votar e ser votado. São atos e atividades que estão condicionados a requisitos de capacidade de que a criança não dispõe. $\mathrm{O}$ adolescente, mesmo, só adquire condições de capacidade para o exercício dessa liberdade após 16 anos de idade (...). Contudo, a criança e o adolescente têm o direito de exercer outras atividades participativas que, num sentido mais amplo, podem configurar-se como políticas. Assim é o direito de organização e participação em entidades estudantis" ${ }^{330}$.
\end{abstract}

Nota-se que, mesmo quando o autor abre a possibilidade de que a participação da criança e do adolescente na vida política tenha um sentido que vá além do direito ao voto, este sentido somente se estende a atividades que seriam próprias a crianças ou adolescentes, como a organização e participação em entidades estudantis.

O mesmo entendimento é compartilhado por Andréa Rodrigues AMIN que, ao comentar o mesmo artigo e inciso, afirma que a "participação livre não se restringe à vida familiar", compreendendo, também, a participação na vida comunitária e política, sendo

\footnotetext{
${ }^{328}$ Há escassa produção acadêmica no Brasil, na área jurídica, sobre o tema. Não há muitos manuais ou cursos publicados para interpretação do ECA.

${ }^{329}$ Art. 16. "O direito à liberdade compreende os seguintes aspectos: (...) VI participar da vida política, na forma da lei".

${ }^{330}$ CURY, Munir (coord.). Estatuto da Criança e do Adolescente Comentado: Comentários jurídicos e

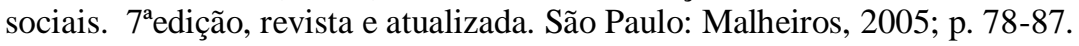


que "reflexo desta última é o direito de voto assegurado aos adolescentes a partir dos 16 $\operatorname{anos}{ }^{331}$.

Outro exemplo está no relatório produzido em 2004 pela ANCED (Associação Nacional dos Centros de Defesa da Criança e do Adolescente) e o Fórum DCA (Fórum Nacional Permanente das Entidades Não Governamentais de Defesa dos Direitos da Criança e do Adolescente) ${ }^{332}$, com o objetivo de "apresentar à sociedade brasileira e, em especial, aos movimentos de defesa da criança e do adolescente os avanços e retrocessos da situação infanto-adolescente e juvenil do País, nesses últimos 10 anos. Pretende ainda, chamar a atenção da comunidade internacional para as graves violações dos direitos desse público (...)". ${ }^{333}$

O documento, denominado "Relatório sobre a situação dos direitos da criança e do adolescente no Brasil", informava que no capítulo 2, seria abordado o Direito à participação, "tendo como enfoque a gestão". O subtítulo do capítulo 2, "Sistema de Proteção dos Direitos Humanos de Crianças e Adolescentes" dava uma pista do conteúdo do referido capítulo, que tratava, não da participação, mas da implementação do Sistema de Garantia de Direitos, conforme a formulação do Conselho Nacional de Direitos da Criança e do Adolescente - Conanda (estruturado em três eixos: promoção, controle e garantia); em momento algum se falava, de fato, de ações promovidas para a garantia do direito à participação (ou da ausência delas).

Apesar de ter se baseado em relatório preliminar elaborado após oficinas com crianças e adolescentes, em que se colheram as suas opiniões (tendo sido promovida, portanto, a participação), esta informação não ganha o devido destaque no documento. No tocante ao conteúdo, o documento informa que o direito à participação implica na

\footnotetext{
331 AMIN, Andrea Rodrigues. "Dos Direitos Fundamentais", In MACIEL, Kátia Regina Ferreira Lobo Andrade. Curso de Direito da Criança e do Adolescente - Aspectos Teóricos e Práticos - $4^{\mathrm{a}}$ Ed. 2009. Porto Alegre, Lumen Juris; p. 31-65; p.46.

${ }^{332} \mathrm{O}$ objetivo principal do documento era ser um relatório alternativo, complementando e contestando os termos do relatório oficial produzido pelo Governo Brasileiro para envio às Nações Unidas, obrigação dos Estados-parte signatários da Convenção. O relatório foi publicado no mesmo ano em que o Brasil submeteu ao Comitê dos Direitos da Criança das Nações Unidas o primeiro relatório sobre o cumprimento da Convenção foi submetido em 2004 (10 anos depois da data inicial devida).

${ }^{333}$ ANCED (Associação Nacional dos Centros de Defesa da Criança e do Adolescente); FÓRUM DCA (Fórum Nacional Permanente das Entidades Não Governamentais de Defesa dos Direitos da Criança e do Adolescente). Relatório sobre a situação dos direitos da criança e do adolescente no Brasil, 2004. Disponível em http://www.anced.org.br/cyberteca/publicacoes/relatorio-alternativo-cdc-2004/RelatorioAlternativo-2004-e-Recomendacoes.pdf/view
} 
efetivação de um Sistema de Garantia de Direitos, e a partir daí discorre a respeito da situação de tal sistema no Brasil.

Ora, a promoção do direito à participação não pressupõe o funcionamento pleno do SGD. A participação pode - e deve - se dar ao longo desse processo, até mesmo para que, nele, sejam integradas as opiniões de crianças e adolescentes. Que fique claro: não se quer, com essa crítica, desvalorizar o conteúdo do relatório, sua importância, ou afirmar que os seus autores não sabiam o significado de participação, mas chama a atenção que, sob este nome, tenha sido veiculado conteúdo que não dizia respeito a tal direito.

Cabe salientar que a mesma entidade produziu, em 2009, novo Relatório alternativo, desta vez destacando com clareza alguns pontos importantes em relação ao direito à participação e sua implementação no Brasil, conforme se verá mais adiante.

Tania da SILVA PEREIRA ${ }^{334}$ também não caracteriza o direito à participação separadamente, referindo-se a ele em algumas passagens ao comentar a liberdade de participar da vida familiar e comunitária (também chamado de direito à convivência familiar e comunitária, previsto no art. 16, V do ECA) e condicionando o exercício deste direito à promoção de políticas públicas, e ao comentar a liberdade de participar da vida política, limitando-se neste caso a citar o mesmo trecho de José Afonso da SILVA acima transcrito. A autora somente se refere à questão da participação de forma mais explícita ao abordar o direito à educação, referindo-se ao fato de as escolas não serem democráticas (e pretenderem enquadrar as crianças e adolescentes no estereótipo do "aluno ideal") e à necessidade de mudança de paradigma no ensino-aprendizagem, fazendo referência à obra do pedagogo Antonio Carlos Gomes da COSTA e associando a participação ao desenvolvimento.

O conteúdo do direito à participação, como se vê, tende a ser interpretado de modo bastante restrito por autores brasileiros da área do direito da infância e juventude, e pouco valorizado, em comparação aos próprios parâmetros interpretativos fornecidos pela ONU, que responde pela norma de referência internacional (a CIDC).

\footnotetext{
${ }^{334}$ SILVA PEREIRA, Tânia da. Direito da Criança e do Adolescente: uma proposta interdisciplinar. Rio de Janeiro: Renovar, 1996; p. 87-88, 303, 321-322. A obra foi reeditada em 2008, sendo possível e provável que tenha havido alterações; a segunda edição, porém, está esgotada nas editoras, não foi encontrada para venda em sebos, e nem para consulta nas bibliotecas da USP, da PUC/SP e nem em bibliotecas de associações das quais a autora faz parte.
} 
O Conanda tem paulatinamente inserido o direito à participação em documentos com força normativa e nos planos das políticas nacionais de direitos da criança e do adolescente. Esta positivação tem acompanhado uma prática que se iniciou, no Brasil, antes mesmo do advento do Estatuto. Ela é, frequentemente, no Brasil, referida pelos trabalhadores e pesquisadores da/com infância e juventude com o uso do termo 'protagonismo juvenil' ${ }^{335}$.

\subsection{Participação de crianças e adolescentes e (é) protagonismo juvenil (?)}

O uso do termo protagonismo juvenil na pedagogia, rapidamente apropriado para as demais áreas do trabalho social com crianças e adolescentes, é atribuído, no Brasil, ao pedagogo Antonio Carlos Gomes da COSTA.

COSTA parte de uma concepção de educação baseada no paradigma do Desenvolvimento Humano ${ }^{336}$, desenvolvido pelo Programa das Nações Unidas para o Desenvolvimento (PNUD) desde a década de 1990. Esta concepção de educação se encontra resumida em um conhecido documento, produzido para a UNESCO (Organização das Nações Unidas para a educação, a ciência e a cultura) em 1996 por Jacques Delors e mais outros quatorze educadores ${ }^{337}$, em que se considera que a educação deve ser desenvolvida em quatro eixos, conhecidos como "os quatro pilares da educação no século XXI":

* Aprender a ser;

\footnotetext{
${ }^{335}$ No Brasil, o uso dos termos parece ser feito de maneira indistinta mesmo na literatura científica, conforme indicam FERRETTI, ZIBAS e TARTUCE em artigo que busca as referências teóricas utilizadas na reforma do ensino médio, mediante estudos de caso realizados em cinco escolas de dois estados, São Paulo e Ceará. Segundo os autores, "a revisão bibliográfica sobre o tema indica que o "protagonismo dos jovens/alunos" é um conceito passível de diferentes interpretações e, além disso, imbrica outros conceitos igualmente híbridos, como "participação", "responsabilidade social", "identidade", "autonomia" e "cidadania". Nem mesmo a distinção conceitual entre "participação" e "protagonismo" é clara na bibliografia consultada. Ou seja, um autor pode-se referir a "protagonismo" em contextos em que outro falaria de "participação", e vice-versa, havendo, ainda, casos em que as duas expressões são usadas como sinônimos.” FERRETTI, Celso J.; ZIBAS, Dagmar M. L.; TARTUCE, Gisela Lobo B. P. Protagonismo juvenil na literatura especializada e na reforma do ensino médio. Cadernos de Pesquisa, v. 34, n. 122, p. 411-423, maio/ago. 2004, disponível em http://www.scielo.br/pdf/cp/v34n122/22511.pdf, consulta 06/11/2011; p. 413.

${ }^{336}$ COSTA, Antonio Carlos Gomes da. Protagonismo Juvenil: O que é e como praticá-lo. Disponível em http://escola2000.net/aprendizagem/ac-protagonismo.htm, consulta em 04/11/11.

${ }^{337}$ UNESCO. Educação: um tesouro a descobrir. Relatório para a UNESCO da Comissão Internacional sobre Educação para o século XXI (destaques). Brasília: UNESCO, 2010. Título original: Learning: the treasure within; report to UNESCO of the International Commission on Education for the Twentyfirst Century (highlights). $\quad$ Paris: $\quad$ UNESCO, $1996 . \quad$ Disponível http://unesdoc.unesco.org/images/0010/001095/109590por.pdf, consulta em 06/11/11.
} 
* Aprender a conviver;

* Aprender a fazer;

* Aprender a aprender.

$\mathrm{O}$ autor parte das características que tornam a sociedade atual extremamente desafiadora nos planos econômico (a globalização dos mercados), tecnológico (a era pósindustrial) e sócio-cultural (cultura pós-moderna).

Essas características se traduzem no elevado custo social que vem a reboque de ajustes estruturais na economia (necessários para a sobrevivência dos países na competitiva economia internacional), mercado e mundo do trabalho cada vez mais complexos, e aumento do distanciamento e do conflito, aliados a uma crise de valores sem precedentes, sendo a busca do prazer imediato e o consumismo expressões emblemáticas desses novos tempos.

A grande consequência, segundo o autor, é o risco de um "enorme crescimento da exclusão social, se a humanidade não for capaz de conciliar a agenda da transformação produtiva, que é econômica e técnico-científica, com a agenda da equidade social, que é essencialmente ético-política" ${ }^{\prime 38}$.

O papel da educação, neste panorama, então, é formar um homem autônomo e solidário, que possa incorporar "os ideais de liberdade do Ocidente e os ideais de solidariedade, que inspiraram o mundo socialista" ${ }^{339}$. Dentro desta visão, educar é "criar espaços para que o educando possa empreender ele próprio a construção do seu ser, ou seja, a realização de suas potencialidades em termos pessoais e sociais", sendo o educando "visto, não como recipiente, mas como fonte autêntica de iniciativa, compromisso e liberdade". O compromisso da educação, portanto, é formar um jovem "autônomo, solidário e competente".

Para ser "autônomo, solidário e competente", o jovem precisa desenvolver competências em quatro esferas, que correspondem aos pilares da educação suprarreferidos: Competência Pessoal (aprender a ser); Competência Social (aprender a conviver); Competência Produtiva (aprender a fazer); Competência Cognitiva (aprender a aprender).

\footnotetext{
${ }^{338}$ COSTA, op cit, p. n/d.

${ }^{339}$ Idem, ibidem
} 
Essas competências e habilidades não podem ser transmitidas apenas por meio da docência (ao menos, não por meio daquela praticada nos moldes tradicionais). "Para criar os espaços necessários à eclosão das práticas e vivências capazes de permitir aos jovens exercitarem-se como fonte de iniciativa, liberdade e compromisso são necessários recursos pedagógicos de natureza distinta da aula. São necessários acontecimentos em que o jovem possa desempenhar um papel protagônico". Nesse contexto, o

"Protagonismo Juvenil, enquanto modalidade de ação educativa, é a criação de espaços e condições capazes de possibilitar aos jovens envolver-se em atividades direcionadas à solução de problemas reais, atuando como fonte de iniciativa, liberdade e compromisso." ${ }^{\text {340 }}$

O cerne do protagonismo, no campo da educação, portanto, "é a participação ativa e construtiva do jovem na vida da escola, da comunidade ou da sociedade mais ampla."

A diferença entre o protagonismo e a participação está em que, segundo o autor, nem toda participação é protagonista, ao contrário, há formas de participação, qualificadas como manipulada, simbólica e decorativa que na verdade, constituem-se em "nãoparticipação".

A participação genuína, pois, necessita de ambiente democrático, para se desenvolver; de outro modo, torna-se manipulação e, em vez de contribuir para o desenvolvimento pessoal e social do jovem, pode prejudicar a sua formação. A autêntica participação promove "ganho de autonomia, autoconfiança e autodeterminação numa fase da vida em que ele se procura e se experimenta, empenhado que está na construção da sua identidade pessoal e social e no seu projeto de vida".

Apesar de a concepção de COSTA ser referência para a implementação de inúmeras experiências de protagonismo no Brasil, não está livre de críticas. Segundo CALIL STAMATO $^{341}$, trata-se de concepção de "caráter naturalizante, que coloca de um lado o homem, com capacidades potenciais a serem desenvolvidas e, de outro, as condições do meio a exercer influência sobre ele, responsável pelo desenvolvimento ou não desses potenciais." Para a autora, há uma contradição intrínseca à concepção de

\footnotetext{
${ }^{340}$ COSTA, op cit. p. n/d.

${ }^{341}$ CALIL STAMATO, Maria Izabel. Protagonismo Juvenil: uma práxis sócio-histórica de ressignificação da juventude. Tese (Doutorado em Psicologia Social). São Paulo, Pontifícia Universidade Católica de São Paulo: 2008.
} 
COSTA, "que, por um lado, enfatiza o jovem como sujeito ativo do processo de aprendizagem e a relação dialógica como elemento fundamental para o protagonismo juvenil, e, por outro, coloca o jovem como um ser passivo, a mercê do meio para despertar seus potenciais. O papel da escola, neste contexto, não é oferecer condições para a educação e sim oferecer oportunidades educativas para as quatro aprendizagens fundamentais se transformarem em competências individuais, garantindo a adaptação do indivíduo. Ou seja, o objetivo último desta proposta educativa não é o protagonismo em si, mas o protagonismo adaptado, regulado."342

A crítica a uma função adaptativa do protagonismo não é dirigida exclusivamente a COSTA, como se verá adiante. Esta, aliás, talvez seja uma das maiores contradições vividas por quem trabalha com crianças e adolescentes, de difícil superação.

O termo adaptação é bastante utilizado pelos teóricos críticos da Escola de Frankfurt, dos quais T. W. ADORNO foi um dos principais expoentes, para criticar maneiras disfarçadas de acomodação de movimentos de transgressão e contestação do sistema capitalista e da sociedade industrial. Uma das grandes críticas feita por esses autores, que cunharam e disseminaram a expressão "Indústria Cultural”, dizia respeito, por exemplo, à popularização do conhecimento 'clássico', antes só acessível aos 'bemeducados'. Assim, a venda de livros 'clássicos' na banca de jornal não proporcionaria, de fato, o acesso do povo aos bens culturais, mas sim uma ilusão desse acesso, acomodando os seus desejos de pertencimento e anulando a sua capacidade de resistência e transformação.

Esta crítica pode, hoje, ser estendida a uma série de ações, projetos e programas de difusão e inclusão cultural, e pode ser aplicada tanto aos movimentos supostamente populares, como o rap e hip hop, que foram apropriados pelos atores sociais como forma de se aproximar das classes sociais baixas e atraí-las para serviços e programas de atendimento (como ONGs culturais e de atendimento à criança), quanto aos serviços que 
buscam oferecer opções culturais mais diversificadas que incluem a arte erudita e tradicionalmente consumida pela elite intelectual ${ }^{343}$.

Se a crítica é válida, porém, a sua problematização também o é. O alerta desses teóricos é extremamente importante na medida em que provoca uma contínua reflexão sobre a ação (qual ação, por que, como, para quem?) e compreensão dos mecanismos mais perversos de funcionamento e manutenção do sistema capitalista - ou ao menos da maneira como foi "fundado". A problematização se faz necessária no momento em que essa crítica pode gerar uma paralisia na ação, pois nenhuma inclusão, no capitalismo, pode ser real. Diante disto, o que fazer? Não é possível cruzar os braços e esperar que as contradições inerentes ao próprio sistema o façam implodir. É preciso agir agora, na esperança que de fato, em algum momento, aconteça uma ruptura.

A reflexão vale para praticamente todo projeto ou programa que pretenda oferecer oportunidades de inclusão de crianças e adolescentes, especialmente os focados em educação, cultura, profissionalização.

E aqui volto ao que já acima asseverei: alguma participação ainda é melhor que nenhuma participação. Alguma participação pode abrir caminho para a verdadeira e completa participação (assim como a obra clássica comprada na banca de jornal pode, quem sabe, abrir o caminho para uma revolução).

Numa gradação que se inicia com uma participação teatralizada, passa por uma participação adaptativa e termina em uma participação promotora de autonomia e emancipatória, se esta última é o ideal a atingir, a primeira não deixa de ter alguma relevância. Não quero, com isso justificar e aplaudir as ações meramente assistencialistas que costumam estar ligadas ao primeiro tipo de participação. Em algumas realidades, porém, este pode ser o único meio de acesso a uma série de oportunidades que são negadas às crianças e adolescentes.

\footnotetext{
${ }^{343}$ É preciso notar que o próprio conceito de cultura, na teoria crítica, é questionável, já que Adorno parte de uma premissa elitista de cultura. Afinal, todos produzimos cultura. Por esta razão buscou-se destacar acima as expressões "clássico" e "erudito", sinalizando que a teoria se aplica à difusão "banalizada" deste tipo específico de cultura.
} 
Isto não exime, porém, o Estado e os demais atores do Sistema de Garantia de Direitos de promover políticas/programas/projetos e ações que tenham como meta a participação real e significativa de crianças e adolescentes.

Continuando o exame da participação e do protagonismo, Renato Souza de ALMEIDA, que estudou a participação juvenil em seu mestrado em sociologia defendido na $\mathrm{PUC/SP}{ }^{344}$, afirma que as formas de participação ligadas à política (no sentido mais 'comum' do termo), consistentes de atuação em movimentos estudantis e partidos políticos, ainda são classificadas como as únicas formas de atuar. As formas de participação que não passam pelo discurso político ilustrado são consideradas novas ou não convencionais (segundo o autor, por uma geração de pesquisadores carregada de nostalgia, que identificaria a participação aos movimentos de jovens ligados ao período de ditadura e luta pela democracia no Brasil).

Conforme lembra ABRAMO, essa caracterização reflete na verdade "uma grande dificuldade de considerar efetivamente os jovens como sujeitos, mesmo quando é essa a intenção, salvo raras exceções; uma dificuldade de ir além da sua consideração como "problema social" e de incorporá-los como capazes de formular questões significativas, de propor ações relevantes, de sustentar uma relação dialógica com outros atores, de contribuir para a solução dos problemas sociais, além de simplesmente sofrê-los ou ignorá-los. "345

As constatações de ALMEIDA e de ABRAMO corroboram a observação acima apresentada a respeito da visão que os juristas têm a respeito da participação. Esta visão limitada provoca uma sensação de que a juventude atual é alienada e despolitizada, já que participam pouco dos espaços políticos tradicionais ${ }^{346}$.

$\mathrm{O}$ autor aponta que, segundo pesquisas, o que tem levado jovens a se organizarem são, em primeiro lugar, as manifestações artísticas, ao invés da ação política stricto sensu. As organizações em torno da cultura, porém, têm gerado reflexões sobre a necessidade de se repensar as categorias para a análise das formas de participação da juventude

\footnotetext{
${ }^{344}$ ALMEIDA, Renato Souza de. Juventude e Participação: Novas Formas de atuação juvenil na cidade de São Paulo. Dissertação (Mestrado em Ciências Sociais). São Paulo: Pontifícia Universidade Católica de São Paulo, 2009; p 10-11.

${ }^{345}$ ABRAMO, op. cit., p. 6.

${ }^{346}$ ALMEIDA, op. cit, p. 10-11.
} 
contemporânea, já que a organização em torno da cultura pode ser interpretada não somente como lazer, mas como uma possível reinvenção da ação política pelos jovens.

Esses grupos de jovens, como rappers, funkeiros, movimento hip-hop e outros, que surgem principalmente nas comunidades pobres, são considerados como desenvolvedores de uma subcultura, conceito que, evidentemente, tem como referência a cultura dominante. Por meio de suas ações, promovem uma reapropriação do que lhes é oferecido pela indústria cultural e uma ressignificação dos valores da cultura dominante, ao invés de rejeitar a tecnologia e a mídia como instrumentos dessa mesma cultura. Pelo contrário, os jovens fazem uso desses instrumentos para ter voz. Ao final, esses movimentos culturais parecem adquirir significado de ação política, já que suas atitudes são contestadoras e provocadoras, ao romperem com as expressões hegemônicas nos trajes, na expressão artística (dança, canto, instrumentais) e no conteúdo das letras.

Outro movimento juvenil apontado por ALMEIDA que destoa da concepção 'tradicional' são as lutas antiglobalização. Esses movimentos são inegavelmente políticos, porém as suas formas de organização, das quais a mais conhecida é Fórum Social Mundial $^{347}$, divergem das formas tradicionais: são coletivas e se focam na força do encontro ao invés da tomada de poder, desafiando as tradicionais teorias sobre a política, e suas propostas decorrem deste tipo de organização.

O autor aponta que os novos movimentos juvenis se organizam em redes, de forma horizontal e plural, congregando diferentes agrupamentos em torno de uma resposta ampla e coletiva. Eles se agregam em torno de temáticas específicas, como a questão ambiental, LGBT, movimento negro, movimento de mulheres etc ${ }^{348}$.

Ao considerar o conceito de política como ação intencional na sociedade, é possível compreender esses jovens como agentes políticos, sujeitos que exercem ações a favor da pólis, atuando em prol de uma determinada causa ou de um determinado segmento. Isso não significa, também, que uma parte desses jovens não tenha interesse pela política partidária, ou pela ação política institucionalizada, mas sim que, naquele

\footnotetext{
${ }^{347}$ O lema do Fórum Social Mundial, "por um outro mundo possível” não é necessariamente contra a globalização em si, mas sim contra a globalização tal como ela se dá pela lógica capitalista, que só aumenta as desigualdades. O sonho é de uma globalização promotora de aproximação entre os povos e de justiça social.

${ }^{348}$ ALMEIDA, op. cit, p. 36.
} 
momento, são capazes de deixar de lado essa estrutura para se dedicar a algo que a transcende ${ }^{349}$.

As conferências institucionais organizadas pelo Poder Público, como as conferências de juventude, e as conferências de direitos da criança e do adolescente, acabam por agregar jovens oriundos de diferentes movimentos sociais, com diferentes bandeiras e propostas, proporcionando a oportunidade do exercício democrático de debate; isso não significa, salienta o autor, que haja, necessariamente, consenso entre os jovens durante essas oportunidades. Pelo contrário, o conflito está presente a todo o momento e é parte integrante desta construção coletiva, afirma ALMEIDA ${ }^{350}$.

O autor parece identificar, portanto, que as formas de participação na sociedade atual contemplam adolescências e juventudes diversas, o que corresponde à realidade, apesar de o encontro entre crianças e adolescentes de classes sociais diversas ainda ser um obstáculo a ser superado (obstáculo este que obviamente está ligado à desigualdade social e econômica intrínsecas ao sistema capitalista e, mais especificamente, à realidade do Brasil).

O que considero importante ressaltar como reflexão a partir da pesquisa de ALMEIDA é que a visão de participação como participação político-partidária é muito limitada, e que há inúmeras e efervescentes formas de genuína participação acontecendo diante dos nossos olhos adultos, sem que muitas vezes sejamos capazes de identificá-las. Pode ser mais fácil desqualificar estas formas de participação para que não seja preciso preocupar-se com as verdadeiras questões levantadas pelos adolescentes, como é possível concluir a partir das considerações de ABRAMO, suprarreferidas.

Resta saber, e isso só o tempo dirá, se estas experiências de participação têm de fato um potencial transformador e levarão a reais mudanças ou se somente servem para acomodar uma parcela da juventude que ainda não se conformou com o status quo.

\footnotetext{
${ }^{349}$ Em 2011, um claro exemplo de movimentos dessa natureza foi o movimento chamado "Occupy Wall Street" (Ocupe Wall Street"). Wall Street é o bairro da ilha de Manhattan, cidade de Nova Iorque, onde ficam as sedes das maiores instituições financeiras dos Estados Unidos e do mundo. A escolha do local é simbólica porque ele representaria algo como "a sede mundial do capitalismo". Esse movimento, composto primordialmente por jovens, tem como uma de suas características a retirada de bandeiras de partidos tradicionais das manifestações; ali, o "fazer política" estava muito mais próximo de uma ágora idealizada e menos de uma hierarquia partidária tal como a dos partidos socialistas/comunistas.

350 ALMEIDA, op. cit, p. 37.
} 
Se é possível colocar em dúvida este potencial, é porque outros autores têm feito leituras sobre o protagonismo que indicam que a sua prática tem sido utilizada menos como oportunidade de real participação e mais como mecanismo de adaptação. O conceito e o conteúdo da participação e do protagonismo não são unânimes. E parecem ser utilizados na maior parte dos casos com um foco específico nas crianças e adolescentes de classe baixa.

Ao estudar o uso do termo "protagonismo" na educação, FERRETTI, ZIBAS e TARTUCE ${ }^{351}$ identificaram que são utilizadas, indistintamente, além de protagonismo, as expressões "participação", "responsabilidade social", "identidade", "autonomia" e "cidadania", não havendo clara distinção conceitual sequer entre os termos "participação" e "protagonismo".

No entender desses autores, o conceito do protagonismo é "reapropriado ${ }^{352 "}$ na sociedade pós-moderna ou pós-industrial, respondendo às mudanças de "paradigmas, valores, concepções e práticas de trabalho, de vida e de educação", e atendendo, portanto, a uma "urgente necessidade social de promover, de maneira sistemática, a formação de valores e de atitudes cidadãs que permitam a esses sujeitos conviver de forma autônoma com o mundo contemporâneo", e configurando-se como uma formação para a "moderna cidadania". Assim, o "protagonismo é encarado, nesse sentido, como via promissora para dar conta tanto de uma urgência social quanto das angústias pessoais dos adolescentes e jovens."

Os autores identificam, no uso do termo protagonismo, não só uma consideração da juventude/adolescência como uma categoria homogênea - o que não corresponde à realidade, mas também uma identificação do protagonismo com a resiliência ${ }^{353}$. Desse modo, o termo "protagonismo" é comumente utilizado para designar a participação das próprias crianças na superação das adversidades.

\footnotetext{
${ }^{351}$ FERRETTI, ZIBAS, TARTUCE, op cit.

${ }^{352}$ A origem do conceito vem do teatro grego, conforme explicam diversos dos autores consultados. Aqui nos interessa o diálogo entre o conceito e prática do termo e o conceito e prática de participação, na atualidade, razão pela qual não houve a preocupação em trazer a história de suas origens e nem de discutir seu significado original.

${ }^{353}$ Resiliência é a "capacidade de pessoas resistirem à adversidade, valendo-se da experiência assim adquirida para construir novas habilidades e comportamentos que lhes permitam sobrepor-se às condições adversas e alcançar melhor qualidade de vida". FERRETTI et al. op cit, p. 417.
} 
Assim, apesar de o termo protagonismo referir-se tanto à participação de adolescentes de todas as classes sociais, "a frequente relação entre protagonismo e resiliência autoriza a hipótese de que, apesar de seu caráter abstrato, as proposições relativas ao protagonismo parecem mirar dois grandes grupos: o dos jovens que, não incluídos entre os pobres, poderiam ser conquistados para realizar ações, principalmente voluntárias, que tenham por alvo os setores empobrecidos da população (inclusive os adolescentes e jovens), tornando-se protagonistas; e o dos jovens que, pertencentes aos setores empobrecidos, desenvolvem ações na perspectiva da resiliência." ${ }^{354}$

Isso evidencia também que as políticas não contemplam a diversidade dos grupos juvenis e nem uma concepção ampliada de direitos que está inserida no ECA, ao estabelecer, como princípio, a igualdade de crianças e adolescentes e a condição peculiar de pessoa em desenvolvimento.

Por fim, os autores apontam, também, uma tendência de promoção "de valores, crenças, ações etc. de caráter mais adaptativo que problematizador". Parece haver uma tendência de desviar "o foco das preocupações do debate político e social sobre tais determinações para o da ação individual ou coletiva", com vistas a minorar, de modo funcionalista, "os aspectos negativos do pós-industrialismo, transferindo aos jovens e adolescentes, individualmente ou em grupo, em especial para os que fazem parte dos setores empobrecidos, a responsabilidade de, conforme o conceito de resiliência, contribuir para superação da adversidade".

As conclusões de FERRETTI, ZIBAS e TARTUCE dialogam com as ideias de ALMEIDA. Enquanto estes identificam, nos discursos sobre o protagonismo, a desconsideração das singularidades dos grupos de adolescentes e jovens, ALMEIDA identifica a existência de experiências significativas de participação em diversos grupos sociais, contemplando a heterogeneidade da adolescência e da juventude. $\mathrm{O}$ fato de ALMEIDA utilizar o termo participação, ao invés de protagonismo, não parece mera coincidência, já que a concepção de participação que utiliza parece ir além da concepção de protagonismo identificada pelos três autores nas literaturas examinadas.

\footnotetext{
${ }^{354}$ FERRETTI et al. op cit, p. 417.
} 
O que há de coincidente entre as análises é que tanto ALMEIDA quanto FERRETTI, ZIBAS e TARTUCE identificam uma tendência despolitizadora em algumas concepções de participação e de protagonismo, seja pela desqualificação do caráter político das participações (por ser praticada em moldes diferentes do 'tradicional'), seja pela promoção, por meio do protagonismo, de uma responsabilização individual, que retira do Estado a responsabilidade de promover as condições necessárias para a superação das diferenças econômicas, sociais e culturais que empurram os jovens para a marginalidade social e tende a promover valores e crenças que levem mais à adaptação do que à real problematização.

Independente do nome adotado, ou do questionamento a respeito de seu real significado, ao mesmo tempo em que as constatações ainda parecem desanimadoras, demonstrando o longo caminho ainda a percorrer, elas desvelam que o movimento tem sido de permanente avanço desde a promulgação do ECA. Num movimento dialético, a participação infantojuvenil parte de uma movimentação política em âmbito internacional e nacional, na década de 80, é positivada nas normas atualmente em vigor (CIDC, CF 88 e ECA), passa a ser implementado na prática e, pouco a pouco, tem sido incorporada na política pública.

\subsection{Participação de crianças e adolescentes nas políticas públicas}

Talvez a primeira prática de relevância promotora de participação de crianças e adolescentes, que chamou a atenção de forma mais contundente, no Brasil, tenha sido o Movimento Nacional de Meninos e Meninas de Rua (MNMMR), fundado em $1983^{355}$.

Impulsionado pelo Unicef, por meio de seus consultores, o MNMMR teve participação importantíssima nas articulações políticas que levaram à redação dos artigos 227 e seguintes da Constituição Federal que, um ano antes da adoção da CIDC, na ONU,

\footnotetext{
355 Aqui serão apresentadas e discutidas algumas iniciativas de inclusão da participação de crianças e adolescentes na política pública no Brasil, de modo geral. Não houve preocupação em abranger a totalidade das políticas/programas/projetos e ações de participação, o que seria impossível e inadequado, considerando a abrangência e objetivos deste trabalho. Também não houve uma preocupação metodológica estrita na busca dessas informações, que foram selecionadas a partir de alguns documentos-chave e são trazidas, aqui, como exemplos, e não como objeto de análise.
} 
já incorporavam alguns de seus mais importantes princípios. Posteriormente, também se envolveu nas discussões e na mobilização para a elaboração do ECA.

Segundo o antropólogo e coordenador nacional do MNMMR à época da aprovação do ECA, Benedito Rodrigues dos Santos, "podemos dizer a promoção e defesa dos direitos da crianças e do adolescente no Brasil nasceu da luta em defesa dos direitos humanos de meninos e meninas de rua. Foi a presença "fora de lugar" e "incômoda" das crianças e adolescentes em situação de rua que trouxeram para a consciência nacional a realidade, o estado de miséria e violência ao qual se encontravam as crianças brasileiros. Situação essa de violação massiva de direitos. (...) O processo de discussão e aprovação do ECA mobilizou crianças, comunidades de base, associações profissionais, entidades dos movimentos sociais, a Igreja, a academia. "Foi uma das maiores mobilizações em torno da aprovação de uma lei já vista na história do País." ${ }^{356} 357$

Após a promulgação do ECA, a partir de 1995, passaram-se a realizar a cada dois anos, Conferências de Direitos da Criança e do Adolescente, convocadas pelo Conanda (Conselho Nacional dos Direitos da Criança e do Adolescente) e organizadas pelos Conselhos de Direitos em nível municipal, estadual e federal. Em 1999, pela primeira vez, realizou-se a conferência com a participação de crianças e adolescentes, por meio das chamadas Conferências Lúdicas ${ }^{358}$. Esta prática foi se disseminando e, atualmente, no Estado de São Paulo, diversas Conferências Municipais de Direitos contam com a participação de crianças, por meio das Conferências Lúdicas.

Em 2001, quase oito mil crianças e adolescentes participaram de conferências lúdicas municipais em 18 cidades, e mais de mil se reuniram na Conferência Lúdica Estadual $^{359}$. Uma delegação de 21 adolescentes foi enviada para participar da Conferência Nacional. Em 2003, crianças e adolescentes passam a ser oficialmente reconhecidos como

\footnotetext{
356 DOS SANTOS, Benedito dos. Entrevista para Rede Andi Brasil. Disponível em http://10anos.redeandibrasil.org.br/o-livro/bibliografia/entrevista_benedito-dos-santos/at_download/file, consulta em 10/11/2011.

357 DIAS, Maria Clarice. O ECA no Brasil: Região Centro-Oeste. Disponível em http://www.promenino.org.br/Ferramentas/Conteudo/tabid/77/ConteudoId/e7df9015-f52b-4b33-aec4b9fc5e0a7dae/Default.aspx

${ }^{358}$ A primeira conferência lúdica foi realizada em 1999 pelo CMDCA/SP [Conselho Municipal dos Direitos da Criança e do Adolescente] em São Paulo, em resposta às "demandas do FMDCA/SP [Fórum Municipal], para ampliação da participação infanto-juvenil nas discussões, avaliações e proposições de políticas públicas." LONGO, Isis. Entrevista ao De Olho no Plano, 19 de julho de 2011. Disponível: http://www.acaoeducativa.org.br/deolhonoplano/not0045.html.

${ }^{359}$ LONGO, op. cit.
} 
delegados, nas Conferências em todos os níveis, e não apenas observadores. A participação foi tema da VI conferência, em 2005 ("Participação, Controle Social e Garantia de Direitos - Por uma Política para a Criança e o Adolescente").

$\mathrm{Na} 7^{\mathrm{a}}$ Conferência assegurou-se aos adolescentes, pela primeira vez, a condição de delegados; na $8^{\text {a }}$ Conferência, eles já representavam $1 / 3$ do total de delegados ${ }^{360}$. Em 2011, mais um passo importante: crianças e adolescentes farão parte das comissões organizadoras da $9^{\text {a }}$ Conferência (2011-2012) em nível Nacional, Estadual, Distrital e Municipal, na proporção de 1 (um) adolescente/criança para 2 (dois) adultos. ${ }^{361}$

Paralelamente a este processo, e/ou em convergência com ele, em 2006, o (Conanda), por meio da Resolução no 113 , de 19 de abril ${ }^{362}$, estabeleceu, pela primeira vez, os parâmetros para a institucionalização e fortalecimento do Sistema de Garantia dos Direitos da Criança e do Adolescente que, conforme o art. $1^{\circ}$ da Resolução,

\begin{abstract}
"constitui-se na articulação e integração das instâncias públicas governamentais e da sociedade civil, na aplicação de instrumentos normativos e no funcionamento dos mecanismos de promoção, defesa e controle para a efetivação dos direitos humanos da criança e do adolescente, nos níveis Federal, Estadual, Distrital e Municipal.”
\end{abstract}

\footnotetext{
${ }^{360}$ BRASIL. Presidência da República. Secretaria de Direitos Humanos. Secretaria Nacional de Promoção dos Direitos da Criança e do Adolescente. Conselho Nacional dos Direitos da Criança e do Adolescente. Construindo a Política Nacional dos Direitos Humanos de Crianças e Adolescentes e o Plano Decenal dos Direitos Humanos de Crianças e Adolescentes 2011 - 2020: Documento Preliminar para Consulta Pública. Brasília, $2010 . \quad$ Disponível em http://portal.mj.gov.br/sedh/conanda/Politica\%20e\%20Plano\%20Decenal\%20consulta\%20publica\%2013\%2 0de\%20outubro.pdf.

${ }^{361}$ BRASIL. Presidência da República. Secretaria de Direitos Humanos. Conselho nacional dos direitos da criança e do adolescente. Resolução no- 149, de 26 de maio de 2011. Dispõe sobre a participação de crianças e adolescentes nas comissões organizadoras da IX Conferência Nacional dos Direitos da Criança e do Adolescente, nas Conferências Estaduais, Distrital e Municipais. Disponível em http://www.direitosdacrianca.org.br/destaques/9a-conferencia/resolucao-no-149-de-26-de-maio-de-2011, Consulta em 19.01.2012.

${ }^{362}$ BRASIL. Presidência da República. Secretaria de Direitos Humanos. Conselho Nacional dos Direitos da Criança e do Adolescente. Resolução 113, 19 de abril de 2006: Dispõe sobre os parâmetros para a institucionalização e fortalecimento do Sistema de Garantia dos Direitos da Criança e do Adolescente. Disponível http://www.fundocrianca.org.br/forum/arquivos/RESOLUÇÃO\%20N\%\%20113\%20CONANDA.pdf Consulta 06.08.2010.

em
} 
Segundo o $\S 4^{\circ}$ do mesmo artigo, o "Sistema procurará assegurar que as opiniões das crianças e dos adolescentes sejam levadas em devida consideração, em todos os processos que lhes digam respeito". Outra previsão que diz respeito ao direito á participação se encontra, novamente, dentre as disposições relacionadas à execução de medida socioeducativa, que devem obedecer a determinados princípios norteadores, dentre os quais sem encontram, conforme o $\S 2^{\circ}$ do artigo 19 , a "construção, monitoramento e avaliação do atendimento socioeducativo, com a participação proativa dos adolescentes socioeducandos".

O Conanda tem procurado de modo sistemático incluir a participação em seus planos de políticas públicas para Crianças e Adolescentes. Evidentemente que a mera inclusão de temas em documentos oficiais não é suficiente para garantir sua implementação, mas o histórico dos Direitos da Criança no Brasil, desde o movimento que culminou na redação do ECA, vem demonstrando que a estratégia de incluir temáticas importantes nos Planos tem resultado em gradativa implementação dos direitos, ainda que não na velocidade que gostaríamos.

Em Documento Preliminar do Plano Decenal dos Direitos Humanos de Crianças e Adolescentes $^{363}$, apresentado à sociedade civil para Consulta Pública em Outubro de 2010 pelo Conanda, alguns desses avanços foram apresentados.

Apontando como um desafio a necessidade de superação das visões "adultocêntricas" sobre a participação das crianças e adolescentes, o documento, indica dois tipos de tratamento dado à questão da participação: ou bem se ignora este direito, sendo que crianças e adolescentes são tratadas como "usuárias" por escolas, entidades de atendimento ou projetos, não se proporcionando a elas experiências de autonomia; ou, "em outras experiências, eles são convocados a legitimar formalidades de "protagonismo", em espaços meramente "lúdicos" ou segregados, em que se demarcam de forma preconceituosa os distintos universos, de adultos e de crianças e adolescentes”.

\footnotetext{
${ }^{363}$ BRASIL. Presidência da República. Secretaria de Direitos Humanos. Secretaria Nacional de Promoção dos Direitos da Criança e do Adolescente. Conselho Nacional dos Direitos da Criança e do Adolescente. Construindo a Política Nacional dos Direitos Humanos de Crianças e Adolescentes e o Plano Decenal dos Direitos Humanos de Crianças e Adolescentes 2011 - 2020: Documento Preliminar para Consulta Pública. Brasília, $2010 . \quad$ Disponível em http://portal.mj.gov.br/sedh/conanda/Politica\%20e\%20Plano\%20Decenal\%20consulta\%20publica\%2013\%2 0de\%20outubro.pdf, p 21-23.
} 
São apontados como avanços as experiências de participação de adolescentes no chamado "Orçamento Criança e Adolescente - OCA" ${ }^{364}$, em fóruns de entidades não governamentais, como o Fórum DCA ou em espaços associativos, como a $\mathrm{ABMP}^{365}$. O relatório participativo da sociedade civil sobre os direitos da criança no Brasil, publicado pela Anced - Associação Nacional dos Centros de Defesa da Criança e do Adolescente (2009), também é apontado como experiência importante, tendo contado com crianças e adolescentes de sete estados brasileiros como autores. Aponta-se, ainda, o Plano Nacional de Enfrentamento à Violência Sexual Infanto-Juvenil, que incorporou o protagonismo infanto-juvenil como um dos seus eixos, incluindo a participação no monitoramento da execução desse Plano. Por fim, a participação de 280 adolescentes dos 5 continentes no III Congresso Mundial de Enfrentamento da Exploração Sexual realizado no Brasil em 2008, incluindo uma delegação bastante representativa da diversidade que caracteriza a adolescência brasileira, com participantes oriundos de centros urbanos, área rural, comunidades quilombolas e indígenas, entre outros.

Contemplando o direito à participação como fundamental para a promoção de direitos das crianças e adolescentes, a Política Nacional dos Direitos Humanos de Crianças

\footnotetext{
364 "O Orçamento Criança e Adolescente (...) OCA constitui o levantamento do conjunto de ações e despesas do orçamento público destinado à proteção e desenvolvimento da criança". A metodologia de apuração e análise do Orçamento Criança, desenvolvida pelo INESC em parceira com outras instituições, como o Unicef, tem como objetivo identificar "o montante previsto e/ou gasto com ações gerais de proteção e desenvolvimento da criança pelo Poder Público em um determinado período". (UNICEF, Fundação Abrinq, INESC. De olho no orçamento Criança. São Paulo, 2005. Disponível em http://www.unicef.org/brazil/pt/de_olho_orcamento_crianca.pdf, consulta em 18.01.2012).

${ }_{365}$ Associação Brasileira de Magistrados, Promotores de Justiça e Defensores Públicos da Infância e Juventude (www.abmp.org). "Em 2008-2010, foi implementado na ABMP o Conselho Consultivo Nacional de Adolescentes e Jovens para promover a participação do segmento infantojuvenil na promoção de seus direitos. [O Conselho] passou a integrar a $\operatorname{ABMP}(. .$.$) e a primeira experiência foi no 22^{\circ}$ Congresso Nacional da ABMP, realizado em Florianópolis (SC), em 2008, no qual participaram 30 crianças, adolescentes e jovens de diferentes regiões brasileiras. Os participantes abordaram assuntos como as violações de direitos, o direito ao desenvolvimento sexual e, sobretudo, a redução da idade penal.

Em 2009, o Conselho Consultivo Nacional de Adolescentes e Jovens foi constituído e hoje é reconhecido pela incidência política obtida em diversos espaços de discussão sobre os direitos da criança e do adolescente, tais como o Comitê Nacional de Enfrentamento da Violência Sexual contra Crianças e Adolescentes, o Fórum Nacional DCA e o Observatório de Boas Práticas. A ABMP foi pioneira no Brasil ao formar a organização, que integra adolescentes e jovens em suas atividades institucionais para a melhoria da Justiça brasileira". "O Conselho é composto por adolescentes e jovens entre 12 e 24 anos, que participam de organizações de protagonismo infantojuvenil de todas as regiões do País". Fonte: http://www.abmp.org.br/projetos.php?pro=3\&idPro=19
} 
e Adolescentes ${ }^{366}$ proposta pelo Conanda para o próximo decênio (Plano Decenal) se estrutura em cinco eixos orientadores:

1. Promoção dos Direitos ${ }^{367}$;

2. Proteção e Defesa dos Direitos ${ }^{368}$;

3. Participação de Crianças e Adolescentes;

4. Controle Social da Efetivação dos Direitos ${ }^{369}$; e

5. Gestão da Política.

Nota-se a centralidade do direito à participação na política. A inserção deste eixo é de extrema relevância, tendo sido concebido como transversal e conectivo, ou seja, "as crianças e os adolescentes devem ser ouvidos nas ações de promoção, proteção e defesa dos seus direitos que fazem parte dos eixos iniciais, mas também na formulação e implementação da Política, constituintes dos eixo-meios subsequentes". A consideração da opinião de crianças e adolescentes sobre as ações voltadas ao seu grupo etário, e a garantia de sua presença "em diferentes espaços e níveis decisórios, de acordo com as peculiaridades do seu estágio de desenvolvimento, é visto aqui como parte do desenvolvimento integral infanto-adolescente" ${ }^{\prime 370}$.

${ }^{366}$ BRASIL. Presidência da República. Secretaria de Direitos Humanos. Secretaria Nacional de Promoção dos Direitos da Criança e do Adolescente. Conselho Nacional dos Direitos da Criança e do Adolescente. Construindo a Política Nacional dos Direitos Humanos de Crianças e Adolescentes e o Plano Decenal dos Direitos Humanos de Crianças e Adolescentes 2011 - 2020...; p 21-23.

367 Segundo o documento, "os dois primeiros (promoção, proteção e defesa dos direitos) são eixos aglutinadores de ações diretamente vinculadas à garantia dos direitos de crianças e adolescentes. (...) A promoção dos direitos implica na geração, utilização e fruição das capacidades de indivíduos e grupos sociais, conforme definição do Ipea (2010), envolvendo a implementação e acesso a políticas públicas que promovam oportunidades ao desenvolvimento integral de crianças e adolescentes”. BRASIL, op cit; p.2.

368 "No caso da proteção e defesa, trata-se de medidas de solidariedade a indivíduos e grupos em resposta a situações de risco e contingências de vulnerabilidade, abrangendo a proteção de crianças e adolescentes que tiveram seus direitos violados ou ameaçados e o acesso à Justiça para responsabilização dos violadores dos direitos infantoadolescentes." Idem, ibidem.

369 "Os últimos eixos, de controle e gestão, agrupam as ações indiretamente vinculadas à garantia dos direitos de crianças e adolescentes, ou seja, são ações-meio que visam garantir as condições necessárias para que os seus direitos sejam respeitados. O fortalecimento das instâncias do Sistema de Garantia dos Direitos, das estruturas de coordenação da política nas três esferas de governo e do financiamento da Política são reafirmadas como condições fundamentais para se alcançar os fins propostos." Idem, ibidem.

370 “EIXO 3 - PROTAGONISMO E PARTICIPAÇÃO DE CRIANÇAS E ADOLESCENTES. Diretriz 06 Fomento de estratégias e mecanismos que facilitem a participação organizada e a expressão livre de crianças e adolescentes, em especial sobre os assuntos a eles relacionados, considerando sua condição peculiar de desenvolvimento, pessoas com deficiência e as diversidades de gênero, orientação sexual, cultural, étnicoracial, religiosa, geracional, territorial, nacionalidade e opção política”. BRASIL. Presidência da República. 
Iniciativa de participação, já acima mencionada, o Relatório Participativo da Sociedade Civil sobre os Direitos da Criança no Brasil, publicado pela Anced em $2009^{371}$ incluiu em seu processo de desenvolvimento a oitiva de crianças e adolescentes a respeito dos assuntos abordados no documento, tendo sido incluídas "crianças que pertencem a grupos em situações de vulnerabilidade, como, por exemplo, meninas, crianças com deficiência, sem-terrinha, crianças que vivem em áreas de conflito armado, indígenas, dentre outros".

O relatório aponta, porém, que ainda há caminho a percorrer, já que não há, ainda, a participação direta de crianças e adolescentes no Conanda ainda não acontece, e a participação das crianças e adolescentes ainda é separada da dos adultos nas Conferências de Direitos.

Iniciativas como a implementação do Depoimento especial (já referido acima) já estão acontecendo em projetos piloto pelo Brasil desde 2003, porém com foco restrito na oitiva de crianças e adolescentes suspeitos de terem sido vítimas de abuso sexual. A iniciativa busca evitar que a criança ou adolescente vítima de abuso sexual passe por mais de uma inquirição durante o processo judicial, buscando promover sua proteção psicológica evitando seu contato com o acusado e a repetição de interrogatórios. Ainda não há iniciativas que garantam uma escuta acolhedora para crianças em todos os procedimentos que lhes digam respeito - o que garantiria sua participação mais genuína e livre nos processos $^{372}$.

Mais que um método de coleta de provas mais eficaz, o depoimento especial busca proteger a criança e o adolescente, evitando ainda mais danos à sua integridade psíquica já abalada pelo abuso sofrido. $\mathrm{O}$ depoimento especial garante não só o direito à participação, mas também a proteção do desenvolvimento saudável.

Secretaria de Direitos Humanos. Secretaria Nacional de Promoção dos Direitos da Criança e do Adolescente. Conselho Nacional dos Direitos da Criança e do Adolescente. Plano Decenal dos Direitos Humanos de Crianças e Adolescentes. Aprovado em 19 de abril de 2011. Disponível em http://www.direitosdacrianca.org.br/midiateca/publicacoes/plano-decenal-dos-direitos-humanos-de-criancase-adolescentes/at downloadfile/arquivo; p. 5.

${ }^{371}$ ANCED (Associação Nacional dos Centros de Defesa da Criança e do Adolescente). Análise sobre os direitos da criança e do adolescente no Brasil: relatório preliminar da ANCED. Subsídios para a construção do relatório alternativo da sociedade civil ao Comitê dos Direitos da Criança das Nações Unidas. Seção DCI Brasil, 2009; p. 11.

372 ANCED, op cit, p. 49. 
Outras iniciativas de promoção ou experiências concretas de participação, de modo geral, que merecem menção, são a inserção do respeito à opinião do adolescente no Sistema Nacional de Atendimento Socioeducativo (Sinase) ${ }^{373}$, que refere em suas diretrizes o direito à participação dos adolescentes na construção, monitoramento e avaliação das ações socioeducativas. O Plano Individual de Atendimento é um dos instrumentos destinados a promover a implementação da participação do adolescente na medida socioeducativa.

O Sinase garante, ainda, ao adolescente em cumprimento de medida socioeducativa o direito de petição direta a qualquer autoridade ou órgão público com prazo de até 15 dias para resposta, além do direito à informação sobre as normas de organização e funcionamento do programa de atendimento, incluindo as previsões de natureza disciplinar e sobre a evolução de seu plano individual, participando da sua elaboração e reavaliação.

As experiências de Justiça Restaurativa ${ }^{374}$ são outro exemplo de prática de participação, implantadas pela primeira vez na década passada, que passaram a ser aplicadas a situações de conflito entre adolescentes e entre adolescentes e adultos, notadamente quando esses conflitos se caracterizam como a prática de uma infração prevista em lei como crime (infração juvenil).

A prática da Justiça Restaurativa pressupõe a participação livre e espontânea, e sem ela não existe e não faz sentido algum. Os dois primeiros projetos-piloto (RS e SP) operacionalizados com adolescentes foram implementados por iniciativa da Secretaria da Reforma do Judiciário do Ministério da Justiça, com apoio do Pnud, e do Centro de Estudos de Justiça das Américas, vinculado à Cepal (Comissão Econômica para a América Latina) e financiamento do Banco Interamericano de Desenvolvimento (BID).

\footnotetext{
${ }^{373}$ O Sistema Nacional de Atendimento Socioeducativo - Sinase, aprovado por meio da Resolução n. ${ }^{\circ} 119$, de 11 de dezembro de 2006 do Conanda, propõe a política socioeducativa como uma articulação em rede e de integração de políticas inter-setoriais: educação, saúde, assistência social, trabalho/emprego, previdência social, cultura, esporte e lazer, segurança pública. Dentre suas determinações está a elaboração de um Projeto Político Pedagógico Institucional, bem como que cada adolescente, ao ingressar na instituição, tenha um Plano Individual de Atendimento (PIA).

374 Para contextualização a respeito da Justiça Restaurativa, cf. a obra de SLAKMON, Catherine; MACHADO, Maíra Rocha; BOTTINI, Pierpaolo Cruz. (Org.). Novas Direções na Governança da Justiça e da Segurança. Brasília: Ministério da Justiça - Secretaria da Reforma do Judiciário, 2006, em particular o artigo de BENEDETTI, Juliana Cardoso . A Justiça Restaurativa em face da Criminologia da Reação Social, p. 491-520.
} 
Vale, por fim, mencionar, na área acadêmica, a pesquisa-ação denominada "Projeto Invertendo a Rota: ações de enfrentamento da exploração sexual infanto-juvenil em Goiás - Proinvert", que teve como finalidade primeira o desenvolvimento de metodologia de trabalho para o enfrentamento da violência sexual infantojuvenil. Articulando sociedade, universidade e governo, o projeto buscou inicialmente, dentre outras ações, caracterizar o fenômeno da prostituição infantojuvenil na região metropolitana de Goiânia. Esta caracterização se deu por meio de um programa denominado Educação Social nas Rotas, por meio do qual se traçou a geografia e a configuração da prostituição infantojuvenil na região metropolitana de Goiânia, realizouse um levantamento do perfil dos adolescentes no trabalho sexual; criou-se e implementou-se uma metodologia de abordagem com os adolescentes e desenvolveu-se uma ação educativa voltada para os adolescentes envolvidos no trabalho sexual e para os potenciais facilitadores da exploração sexual desses adolescentes ${ }^{375}$.

Outras ações foram desenvolvidas no projeto, em outros eixos, mas o destaque aqui se dá para a caracterização dos adolescentes no trabalho sexual. Com muito respeito, e utilizando-se de diversas abordagens, a equipe de pesquisadores conseguiu conversar tanto com crianças e adolescentes que oferecem trabalho sexual nas ruas quanto com aqueles que trabalham em casas fechadas (bordéis, casas de massagem e boates de striptease). $\mathrm{O}$ resultado dessas entrevistas fornece um riquíssimo conteúdo que problematiza a noção de que adolescentes, não importa em que condições, são sempre vítimas da exploração sexual:

“Os dados coletados pela pesquisa servem para desconstruir a noção recorrente de que situações de violência e pobreza são determinantes para a inserção das adolescentes na prostituição. A maioria dos relatos claramente envolve essas variáveis - o que faz com que grande parte das adolescentes se encontre em situações de vulnerabilidade social -, mas é preciso considerar também que a prostituição pode ser simplesmente uma escolha" ${ }^{376}$.

A pesquisa apurou, ainda, que muitas adolescentes iniciam-se na prostituição por meio de uma amiga, ou de sua irmã, também adolescentes - e não, necessariamente, pela mão de um aliciador. Tendo já exercido outras funções que requeriam pouca qualificação,

375 DOS SANTOS, Benedito Rodrigues; ARAÚJO, Rogério. O enfrentamento da exploração sexual infantojuvenil: metodologia de trabalho e intervenção. Goiânia: Cânone Editorial, 2009; p. 25.

${ }^{376}$ DOS SANTOS, Benedito Rodrigues; ARAÚJO, Rogério, op. cit., p. 98. 
e diante do impedimento legal para o trabalho para menores de dezesseis anos, "a venda do sexo pode se transformar em opção de sobrevivência e de realização dos desejos de consumo para crianças e adolescentes que não podem ou não querem viver com suas famílias ou, ainda, cujos parentes não têm condições de prover suas necessidades. Assim, o trabalho sexual oferece a possibilidade de autonomia em relação à família e de aquisição de bens e serviços que conferem status e pertença social" ${ }^{377}$.

Diante dessas constatações, torna-se necessário repensar a forma de atender esse grupo específico. Problematiza-se, a partir das falas desses sujeitos, toda a política de atendimento, que não pode, por exemplo, limitar-se a buscar o banimento do trabalho sexual e da exploração sexual ${ }^{378}$, mas deve também contemplar outras formas e metodologias de atendimento às crianças e adolescentes envolvidos nestas atividades, de modo a dar conta de uma ampla gama de situações identificadas a partir das oitivas dos envolvidos.

Resultados de pesquisa como estes demonstram o quanto participação de crianças e adolescentes é essencial para o pensar das políticas. É a partir das suas realidades e vivências, conjugadas com o nosso olhar orientado pelos direitos a elas garantidos, que podemos traçar o caminho para políticas que realmente garantam a elas o direito de serem cidadãos, crianças e adolescentes, plenos.

As iniciativas acima elencadas (bem como outras não listadas neste trabalho) dão conta de uma série de facetas do direito à participação, infelizmente ainda de forma incipiente. Outras, porém, ainda precisam ser consideradas e promovidas, a partir da consideração de peculiaridades dos destinatários, crianças e adolescentes.

O direito à informação adequada, por exemplo, é um requisito essencial para o exercício pleno do direito à participação. É preciso garantir que a criança e o adolescente sejam informados sobre as opções possíveis e as consequências derivadas dessas opções ${ }^{379}$.

\footnotetext{
${ }^{377}$ Idem, ibidem, p. 99.

${ }^{378}$ A diferença entre trabalho sexual e exploração sexual é que nesta última há a interferência de um agenciador, que explora o trabalho das crianças e adolescentes, enquanto que no trabalho sexual a criança/adolescente é independente, apesar de, em qualquer caso, haver a intervenção de adultos, já que são eles os donos dos locais de moradia e de alguns locais onde as crianças/adolescentes prestam os serviços sexuais (pode haver a prestação de serviços em locais como banheiros públicos).

${ }^{379}$ HODGKIN, Rachel; NEWELL, Peter. op. cit., p. 461.
} 
Atenção especial à participação das meninas (crianças e adolescentes do sexo feminino) é outro ponto importante. No Brasil, parece não haver diferenças tão sensíveis em termos de oportunidades de participação para meninos (crianças e adolescentes do sexo masculino) e meninas (isso é grave em alguns países, todavia). Sabe-se, porém, que neste país ainda há desigualdades no tratamento às mulheres que se refletem em preconceitos, salários menores, acesso mais difícil a cargos de alto escalão - na política e nos setores público e privado e, a pior delas, a violência física e psíquica. A questão de gênero se torna mais sensível quando se consideram algumas questões específicas, dentre elas a sexualidade.

O acesso a canais de denúncia para os mais diversos tipos de violência praticada contra crianças e adolescentes também é apontado como prioritário. Medidas devem ser tomadas não somente para garantir, portanto, a existência do canal de denúncia, mas também para informar a criança e o adolescente a respeito de sua existência, promover modos de acesso amigáveis e adequados, e promover um atendimento que seja também amigável e adequado às idades e condições diferentes de cada usuário.

Neste ponto, o Brasil tem avançado ao criar um canal de denúncias cujo número, hoje, é de fácil memorização (Disque 100, atualmente denominado Disque Direitos Humanos),

Para além disso, devem ser oferecidas, sempre, oportunidades para que a criança possa relatar, em qualquer âmbito de sua vida (escola, família, instituições, polícia ou canais específicos, entre outros) e de modo não revitimizador, violências ou violações de direitos.

Em resumo, a participação é direito que pode e deve ser implementado nas mais diversas instâncias, do nível local ao nacional, na família, na comunidade, na escola, na formulação das políticas, nas questões ambientais, de educação, de saúde, de segurança pública, de habitação, de trânsito, nas questões de trabalho (especialmente de trabalho infantil), somente para citar algumas, no âmbito individual, coletivo ou no âmbito da formulação de políticas.

Desnecessário dizer que, para tornar reais todas as iniciativas e garantias acima mencionadas, é imprescindível formar profissionais e informar a família. Como já dito, a 
prática da participação não é simples - e aqui nem seria necessário se referir especificamente às crianças e adolescentes, já que o Brasil é um país que ainda tem um longo caminho a percorrer para superar déficits de participação inclusive de seus cidadãos adultos-, e requer aprendizado: aprender a olhar diferente, a ouvir, a considerar, a incluir. 


\section{Capítulo 4. Infância, adolescência e desenvolvimento: o direito de ser criança e de ser adolescente.}

Conforme acima apontado, nota-se em diversos artigos da CIDC e do ECA, e decorrentes interpretações, que o direito à participação de crianças e adolescentes é, com frequência, associado (e, em certos casos, condicionado) a uma avaliação a respeito da idade, maturidade, capacidade de se expressar ou de formar uma opinião.

Esta associação aponta para a conexão clara entre o direito à participação e o direito ao desenvolvimento. A participação é necessária no processo de desenvolvimento não só da sociabilidade, mas tem papel relevante no desenvolvimento cognitivo e moral.

Ao se considerar estratégias de prevenção vitimal da violência sexual mediada pela TIC esses dois aspectos/direitos da infância e adolescência, conectados, precisam ser incluídos na equação.

A participação, como já ficou claro, é crucial porque, para além da orientação e supervisão que adultos devem desempenhar, acompanhando crianças e adolescentes no uso da tecnologia, é preciso fornecer a crianças e adolescentes o "instrumental" ético (respeito, autorrespeito, prudência, solidariedade etc) e técnico para "navegar" entre os mundos sociais on e off-line.

O desenvolvimento, porque as realidades e especificidades das realidades de crianças e adolescentes devem ser respeitadas ao se traçar estratégias de prevenção, bem como as características de cada etapa de vida: crianças são diferentes de adolescentes, crianças e adolescentes são diferentes entre si (mas todos devem ter seus direitos igualmente promovidos e respeitados). No caso específico da prevenção vitimal da violência sexual mediada pela TIC, é preciso notar que, se o desenvolvimento sexual ocorre, biologicamente, em momentos semelhantes, as realidades em que crianças e adolescentes estão inseridas durante esse processo são diferentes: enquanto algumas têm acesso à informação e serviços de saúde e prevenção, outras, logo ao ingressar na puberdade, engrossarão as estatísticas de gravidez na adolescência. Enquanto algumas têm orientação parental e escolar para o uso da TIC, garantia do direito à educação e perspectivas de inserção no mercado de trabalho, outras abandonam a escola para 
trabalhar em empregos informais e aprendem a utilizar a tecnologia sem qualquer supervisão.

Novamente, parte-se dos dispositivos legais nas ordens internacional e nacional, para só então passar-se à caracterização biológica e psicossocial do desenvolvimento de crianças e adolescentes.

\title{
4.1. O desenvolvimento de crianças e adolescentes na esfera jurídica internacional e nacional.
}

Assim como o direito à participação, o direito ao desenvolvimento não foi reconhecido no ordenamento jurídico brasileiro com este específico nomem juris, tendo sido integrado em diversos dispositivos.

$\mathrm{Na}$ CIDC, é o artigo 27 que consubstancia o direito ao desenvolvimento e as diretrizes gerais para sua implementação:

\begin{abstract}
"Artigo 27
1. Os Estados Partes reconhecem à criança o direito a um nível de vida suficiente, de forma a permitir o seu desenvolvimento físico, mental, espiritual, moral e social.

2. Cabe primacialmente aos pais e às pessoas que têm a criança a seu cargo a responsabilidade de assegurar, dentro das suas possibilidades e disponibilidades económicas, as condições de vida necessárias ao desenvolvimento da criança. (...)"
\end{abstract}

Intimamente articulados ao artigo 27 estão o artigo $6^{\circ}$ (garantia do direito à vida, à sobrevivência e ao desenvolvimento) e o artigo 29, que garante o direito à educação, que por sua vez se destina a "Promover o desenvolvimento da personalidade da criança, dos seus dons e aptidões mentais e físicos na medida das suas potencialidades”, sendo este objetivo o primeiro de uma série de quatro, indicando que a promoção do desenvolvimento é objetivo primordial da educação.

\footnotetext{
${ }^{380} \mathrm{O}$ artigo conta ainda com os itens 3 e 4, não transcritos acima por não dizerem respeito diretamente ao tema da análise.
} 
Por fim, e não menos importante, o artigo 24 da Convenção garante o direito à saúde, dispondo a respeito da importância dos cuidados primários (incluindo nutrição), das medidas de prevenção e do fornecimento de informações sobre saúde, higiene e prevenção de acidentes, entre outros.

O Comitê para os Direitos da Criança das Nações Unidas identifica a primeira infância como o período que vai do zero aos oito $\operatorname{anos}^{381}$. No tocante a este período, aponta alguns aspectos que se relacionam ao desenvolvimento que merecem menção, por oferecer alguns parâmetros interpretativos para a Convenção. Alguns desses parâmetros integram conteúdos interdisciplinares, e dizem respeito a aspectos do desenvolvimento que serão abordados adiante.

Durante a primeira infância, as crianças experimentam o mais intenso período de crescimento e mudança durante toda a vida humana: seus corpos amadurecem, assim como o sistema nervoso, há ganhos crescentes de mobilidade, de habilidades de comunicação e de capacidade intelectual, e passam por rápidas mudanças em seus interesses e habilidades. Os primeiros anos são fundamentais para o desenvolvimento integral da criança. Para este desenvolvimento, é necessária a orientação, cuidado e proteção de pais e responsáveis, com respeito às suas individualidades, interesses e capacidades, que variam individualmente e também devido a diferentes condições sociais, culturais e econômicas, e às oportunidades a elas oferecidas.

As relações estabelecidas durante a primeira infância com outras crianças são importantes para o aprendizado da socialização, do compartilhar, da resolução de conflitos, da responsabilidade. Mesmo pequenas, as crianças têm senso das dimensões do mundo em que estão inseridas, e este aprendizado é progressivo e se dá considerando as atividades que realiza e as interações com os outros ${ }^{382}$.

Assim como o direito à participação precisa ser integrado a outras disposições da Convenção para sua integral interpretação, para a garantia do direito ao desenvolvimento é necessário integrar diversas outras garantias e aspectos também previstos na Convenção

\footnotetext{
${ }^{381}$ UNITED NATIONS. Committee on the Rights of the Child. Convention on the Rights of the Child. General Comment no. 7: Implementing child rights in early childhood. Fortieth Session; Geneva, 12-30 September 2005. disponível em http://www2.ohchr.org/english/bodies/crc/comments.htm, consulta em $25 / 11 / 2011$.

${ }^{382}$ UNITED NATIONS, op. cit., p 3.
} 
de forma explícita ou implícita. A saúde e o bem estar psicossocial das crianças são interdependentes, e podem ser ameaçados por condições de vida adversas. Assim, a implementação do direito ao desenvolvimento deve ser feita a partir de uma abordagem holística, e inclui, entre outros, os direitos à vida, à nutrição adequada, à segurança social, a padrões de vida adequados, a um ambiente seguro e saudável, à educação e ao brincar (previstos nos arts. 24, 27, 28, 29 e 31 da CIDC) ${ }^{383}$.

O direito ao desenvolvimento compreende, obviamente, o respeito à opinião e aos sentimentos da criança, e pressupõe que a ela seja dada a oportunidade de se expressar a respeito de todos os assuntos que lhe digam respeito. Articula-se, portanto, com o já mencionado artigo 12 da Convenção (que consubstancia o direito à participação).

É na relação da participação com o desenvolvimento, como já dito acima, que se expressam alguns dos pontos de vista mais comuns e equivocados a respeito das crianças, como a crença de que elas não sabem se manifestar e de que não têm capacidade para entender o que se passa ou fazer escolhas. A imaturidade é frequentemente invocada como motivo para a não participação.

Esta visão reflete, como já dito, a Doutrina da Situação Irregular, que corresponde à desconsideração das crianças como sujeitos de direitos, à sua tutela e à tomada de decisões (das mais corretas às mais violentas) em seu nome com base em uma ideologia de proteção. A negativa total da participação, que é baseada na falta de compreensão do que é ser criança e ser adolescente e do que significa o processo de desenvolvimento, é só o aspecto mais extremo de um leque cinzento de outras negativas possíveis, com resultados mais ou menos violadores aos direitos das crianças ${ }^{384}$.

É preciso ter em conta que as capacidades das crianças e adolescentes evoluem com o tempo, e progressivamente vão adquirindo conhecimento, competências diversas e compreensão - inclusive sobre seus direitos, e o respeito a este processo é crucial para a

\footnotetext{
${ }^{383}$ Idem, ibidem, p. 4.

${ }^{384}$ Durante a vigência das legislações anteriores ao ECA, no Brasil, e até mesmo após sua entrada em vigor, esta negativa de participação e a falta de compreensão do que é o desenvolvimento se refletia, por exemplo, na retirada de crianças do seio de famílias cujo único problema era a pobreza, com consequente internação das crianças em abrigos ou na internação de crianças órfãs, desvalidas e infratoras em instituições como a FEBEM. Todas estas crianças eram enquadradas na categoria jurídica da "situação irregular", termo vigente no então Código de Menores'. Tudo isso acontecia, é evidente, sem a oitiva da criança/adolescente e/ou sem a consideração de sua opinião.
} 
realização de seus direitos. As oportunidades de participação, seja em âmbito familiar, seja em âmbito social (escola, comunidade, vida política etc), devem ser, portanto, gradativamente e continuamente ajustadas a esses diversos momentos do amadurecimento infanto-juvenil ${ }^{385}$.

É preciso lembrar, ainda, que crianças e adolescentes têm capacidade de ajudar e ensinar umas às outras. Este processo de cooperação e aprendizagem entre pares é extremamente importante no processo de desenvolvimento. $\mathrm{O}$ aprendizado cooperativo se dá tanto no âmbito das brincadeiras e jogos (crianças mais velhas ensinam a crianças menores as regras dos jogos e a inserem na brincadeira ${ }^{386}$, às vezes como "café-com-leite"). Práticas pedagógicas desenvolvidas em escolas democráticas como "Sumerhill ${ }^{387}$ " (Inglaterra), "Escola da Ponte ${ }^{388 " ~(P o r t u g a l), ~ e, ~ e m ~ S a ̃ o ~ P a u l o, ~ " L u m i a r ~} 389 "$ incluem atividades cooperativas e situações em que crianças e adolescentes em diferentes estágios de desenvolvimento participam e aprendem juntas, ensinando umas às outras.

Os direitos de brincar e de descansar também estão implícitos e relacionados ao direito ao desenvolvimento. Garantidos no artigo 31 da Convenção, são muitas vezes negligenciados pelas políticas públicas, escolas e pais ou responsáveis. Os tempos de crianças e adolescentes são diferentes dos tempos dos adultos. Além disso, o descanso é essencial - já se provou cientificamente que ele é crucial para o desenvolvimento neurológico e físico (ossos, músculos etc.) que acontece durante a infância e a juventude, (além de ser importante para a aprendizagem e para a recuperação do corpo, durante a vida toda). Crianças e adolescentes necessitam de mais (ou menos) descanso conforme a fase de desenvolvimento em que se encontram. Esta necessidade é mais intensa durante os estágios iniciais de desenvolvimento e, depois, na adolescência: são os dois períodos em

\footnotetext{
${ }^{385}$ Idem, ibidem, p. 8.

${ }^{386}$ Nota-se que a compreensão do processo de desenvolvimento existe nas crianças de forma clara, o que se expressa na prática da participação em jogos como 'café-com-leite'. O participante 'café-com-leite' é aquele que ainda não conhece ou não entende bem as regras do jogo ou é muito pequeno para participar em igualdade com as crianças maiores. A possibilidade de agir como um observador-participante dá ao 'cafécom-leite' a chance de aprender as regras e posteriormente, quando já tiver a compreensão das regras, participar efetivamente.

${ }^{387}$ Summerhill é conhecida como a primeira escola democrática do mundo, fundada em 1921. Para mais informações: http://www.summerhillschool.co.uk/pages/index.html

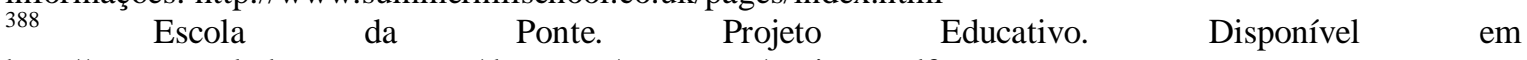
http://www.escoladaponte.com.pt/documen/concursos/projecto.pdf

${ }^{389}$ A Lumiar é uma das primeiras escolas democráticas do Brasil, tendo sido premiada internacionalmente por sua metodologia inovadora; sua fundação, em 2002, foi capitaneada pelo empresário Ricardo Semler. http://www.lumiar.org.br/2009/home.php
} 
que há maior desenvolvimento em curto período de tempo. Porém, o descanso é necessário e salutar durante todo o período.

Segundo Tania da Silva PEREIRA ${ }^{390}$, é comum que os adultos interpretem os jogos como recreação, tolerando as brincadeiras das crianças desde que não os atrapalhem. A brincadeira, porém, não é mera recreação (e, ainda que o fosse, não seria menos merecedora de respeito), mas faz parte do processo de desenvolvimento de capacidades como pensamento e linguagem, simbolização ${ }^{391}$, criatividade e socialização, dentre outros. "É através das brincadeiras e dos jogos organizados que ela [a criança] pode desenvolver a concentração, persistência, paciência e espírito esportivo e de grupo." ${ }^{392}$

MACHADO considera, no mesmo sentido, que o direito de brincar é essencial, já que preso ao desenvolvimento cognitivo da criança/adolescente, assim como ao desenvolvimento psicológico e social, ganhando contornos de essencialidade tal que o eleva à categoria de direito fundamental de crianças e adolescentes ${ }^{393}$.

Preencher a agenda de crianças e adolescentes com dezenas de atividades de aprendizagem durante a semana toda (ou com obrigações de trabalho doméstico ou fora de casa), sem espaço para descanso e lazer, ao contrário do que diz o senso comum, ao invés de ser positivo, prejudica o seu desenvolvimento. A esse respeito, Nylse CUNHA, citada

\footnotetext{
390 SILVA PEREIRA, Tânia da. Direito da Criança e do Adolescente: uma proposta interdisciplinar. Rio de Janeiro: Renovar, 1996; p. 50.

${ }^{391}$ UNITED NATIONS, op. cit., p. 15. Todo pai e mãe, assim como quem convive com crianças, certamente já vivenciou uma ou mais situações similares a esta: certa vez os filhos de um amigo, que eu visitava, receberam uma coleguinha que acabara de vivenciar o trabalho de parto de sua mãe, que acontecera em casa com o auxílio de uma parteira, e demorara cerca de 18 horas. Foi uma experiência muito impactante para a criança, que tinha 4 anos de idade. Fui então escolhida para participar de uma brincadeira em que eu representava uma mulher grávida em trabalho de parto muito doloroso, sendo que a menina, líder da brincadeira, era a parteira/enfermeira, que me dava todos os remédios e aconselhamentos para que eu melhorasse. Ao final, 'dei à luz' ao bebê. Neste caso, foi evidente o impacto que a situação causou na menina, e sua necessidade de simbolizar e "processar" internamente a vivência, reproduzindo-a na brincadeira. A seguinte afirmativa de PEREIRA se coaduna com esta minha conclusão, que adveio, à época, de mera observação: "o sentido da vida e a dimensão de suas possibilidades são dados à criança quando ela brinca. Nessa aparente fantasia acontece a expressão de uma realidade interior, proporcionando oportunidades de transferências significativas que resgatam situações conflituosas". (SILVA PEREIRA, Tânia da, op. cit., p. 51.

392 SILVA PEREIRA, Tânia da, op. cit., p. 51.

${ }^{393}$ MACHADO, Martha de Toledo. A proteção constitucional de crianças e adolescentes e os direitos humanos. Barueri: Manole, 2003; p. 195. Aliás, em estudo específico sobre crimes sexuais contra crianças e adolescentes, a autora considera que o conteúdo da liberdade de brincar, que implica, ainda, na liberdade de fantasiar e experimentar, "condiciona, juridicamente, o conteúdo da liberdade sexual de crianças e adolescentes, fundando (e gerando) um dever de abstenção para os adultos; qual seja, o dever de abster-se de praticar ato sexual de relevo com ou contra crianças e adolescentes". MACHADO, Martha de Toledo. Proibições de excesso e proteção insuficiente no direito penal..., p.149. [itálicos no original]
} 
por PEREIRA, assevera, com razão, que "os adultos querem que a criança se socialize, que aprenda, que se desenvolva, que seja equilibrada e responsável, que preste atenção no que está fazendo, que se acostume a trabalhar, mas afinal... tudo isso não é exatamente o que a criança faz quando está brincando?"394

Além da Convenção sobre os Direitos da Criança, outros documentos internacionais, como o Protocolo Facultativo à Convenção sobre os Direitos da Criança referente à Venda de Crianças, à Prostituição infantil e à Pornografia Infantil, das Nações Unidas (ratificado por 129 Estados, em 15 de novembro de 2008), a Declaração e Agenda para Ação de Estocolmo (The Stockholm Agenda for Action against Commercial Sexual Exploitation of Children, 1996), e a Convenção $n^{\circ} 182$, da Organização Internacional do Trabalho (OIT), adotada em 1999 e que dizem respeito diretamente a direitos da criança, integram a normativa internacional no que toca ao direito ao desenvolvimento.

Notadamente, destacado aqui por ser diretamente relacionado ao tema do presente trabalho, o referido Protocolo Facultativo sobre a Venda de crianças, Prostituição e Pornografia Infantil apresenta uma série de medidas que devem ser tomadas pelos Estados-parte para a garantia dos direitos das crianças. Reconhecendo sua vulnerabilidade, incluem-se dentre os deveres dos Estados a coleta de depoimentos de forma amigável e protegida, o direito à informação, a consideração das opiniões, necessidades e preocupações das crianças vítimas no processo, a celeridade processual e a proteção de sua intimidade, entre outros, previstos nos artigos 8 e 9 do documento ${ }^{395}$.

$\mathrm{Na}$ legislação brasileira, o direito ao desenvolvimento veio incorporado em diversos artigos, consubstanciado no direito ao respeito à condição peculiar de pessoa em desenvolvimento, e é considerado um verdadeiro princípio de interpretação do ECA (e de todo o Sistema de Garantia de Direitos).

\footnotetext{
${ }^{394}$ CUNHA, Nylse Helena da Silva. "Brinquedoteca: definição, histórico no Brasil e no mundo". In: O direito de brincar: a brinquedoteca. Adriana FRIEDMANN [et. al.] (coord.) São Paulo: Scritta:Abrinq, 2002 apud SILVA PEREIRA, Tania, op. cit. p. 51.

${ }^{395}$ ORGANIZAÇÃO DAS NAÇÕES UNIDAS. Protocolo Facultativo à Convenção sobre os Direitos da Criança relativo à venda de crianças, prostituição e pornografia infantis. Disponível em http://www.unicef.pt/docs/pdf/protocolo_facultativo_venda_de_criancas.pdf, consulta em 14.11.2011.
} 
Martha de Toledo MACHADO, aliás, situa o direito ao desenvolvimento dentro dos direitos de personalidade, já que "a possibilidade de desenvolver a personalidade humana (...) é pré-requisito da própria noção jurídica de personalidade (...)" (itálico no original $)^{396}$. Este direito, portanto, ocupa lugar central no que a autora considera como um sistema especial de proteção dos direitos fundamentais de crianças e adolescentes.

O respeito à peculiar condição de pessoa em desenvolvimento é, portanto, fundamento para que se efetivem os demais direitos fundamentais de crianças e adolescentes, direitos estes que fazem parte de um sistema constitucional especial de direitos de crianças e adolescentes.

Antes mesmo de apresentar o rol de direitos do artigo $4^{\circ}$, aliás, a oportunidade de desenvolver-se de maneira integral é apresentada como o objetivo de todo o sistema de proteção especial: "Art. $3^{\circ}$ A criança e o adolescente gozam de todos os direitos fundamentais inerentes à pessoa humana, sem prejuízo da proteção integral de que trata esta Lei, assegurando-se-lhes, por lei ou por outros meios, todas as oportunidades e facilidades, a fim de lhes facultar o desenvolvimento físico, mental, moral, espiritual $e$ social, em condições de liberdade e de dignidade" (destaquei).

Não é por outra razão que a peculiar condição de pessoa em desenvolvimento deve ser considerada central no sistema de proteção de crianças e adolescentes, sendo, ao mesmo tempo, seu fundamento, princípio interpretativo e fim último.

Fundamento porque a razão de ser do sistema de proteção é a peculiar condição de pessoa em desenvolvimento. Aliás, a própria prioridade absoluta que, conforme o artigo $4^{\circ}$ do Estatuto, deve ser assegurada a crianças e adolescentes no respeito aos seus direitos, também pressupõe tal condição. Assim, a tutela jurisdicional diferenciada ${ }^{397}$ que merecem os direitos de crianças e adolescentes, pode ser traduzida em uma simples e inesquecível expressão, inúmeras vezes repetida, em suas aulas, pelo próprio Paulo Afonso Garrido de PAULA: "criança tem pressa".

\footnotetext{
${ }^{396}$ MACHADO, A proteção constitucional..;, p. 109.

${ }^{397}$ Com a expressão, o autor e Professor de Direito da Criança e do Adolescente se refere à necessidade de um olhar diferenciado para os pedidos de tutela jurisdicional de direitos de crianças e adolescentes já que, por estarem em desenvolvimento, a demora na garantia do direito pode significar a perda total da possibilidade de seu exercício, com prejuízos, por vezes, irreparáveis para esses sujeitos. Cf. PAULA, Paulo Afonso Garrido de. Direito da criança e do adolescente e tutela jurisdicional diferenciada. São Paulo: RT, 2002.
} 
Criança (e adolescente, incluído implicitamente na afirmação do autor) tem pressa porque o seu desenvolvimento (físico, mental, espiritual, moral e social), não pode esperar. Porque a sua saúde é mais frágil que a dos adultos, já que ainda está em desenvolvimento seu sistema imunológico; porque a desnutrição pode causar prejuízos graves ao seu organismo, prejudicando não só sua saúde, de forma imediata e a longo prazo, mas também seu desenvolvimento cognitivo (o que refletirá, conforme PIAGET, no seu desenvolvimento moral); porque o desenvolvimento social depende da garantia de um direito à convivência familiar e comunitária e, porque não dizer, do direito à educação (já que, se o desenvolvimento moral/social se dá, inicialmente, no seio familiar, mais adiante é fundamental a convivência entre pares para vivenciar diferentes situações de cooperação, solidariedade, co-aprendizagem, de frustrações e injustiças, tão necessárias para o aprendizado da vida em sociedade).

Assim, não fosse tal condição, crianças e adolescentes não seriam merecedores de proteção especial. Esta, aliás, é a mesma razão que fundamenta a existência de outros dispositivos legais de proteção para determinados grupos considerados vulneráveis, como, por exemplo, o Estatuto do Idoso.

Condição peculiar de pessoa em desenvolvimento é também princípio de interpretação do Direito da criança e do Adolescente, porque deve iluminar a intepretação das disposições do ECA, bem como a sua integração com as demais normas nacionais e internacionais, sejam elas específicas para crianças e adolescentes ou não.

E fim, porque o que se busca garantir é que, com liberdade e dignidade, crianças e adolescentes possam ser, sendo que a possibilidade de formar a personalidade humana adulta, direito fundamental do ser humano sem o qual não podem ser os demais direitos da personalidade, é parte integrante e indissociável desse $\operatorname{ser}^{398}$.

Por fim, é bom lembrar que tanto a CIDC quanto o ECA, ao reconhecer crianças e adolescentes como sujeitos de direitos, afastam a possibilidade de interpretar-se o direito ao desenvolvimento (ou o direito de formar a personalidade humana adulta) como o único aspecto relevante de sua personalidade. Ao reconhecer crianças e adolescentes como detentores de direitos e de responsabilidades, podendo exercer esses direitos contra todos e 
serem demandados, eventualmente, a responder por violações de direitos alheios (como, por exemplo, no caso da prática de ato infracional), reconhece-se que ser criança e ser adolescente significa exercer todos os seus direitos em plenitude, enquanto se é criança e adolescente. Ou seja, a proteção legal especial não tem por objetivo, somente, garantir que possam vir a se tornar adultos, mas sim que possam, agora, exercitar plenamente (isto é, com saúde, liberdade, dignidade) seus direitos de brincar, conviver, educar-se etc. ${ }^{399}$

É neste mesmo espírito que Tânia da Silva PEREIRA identifica, dentre as garantias do ECA, o "direito de ser criança e adolescente" ", que nomeia o capítulo 2 de sua leitura interdisciplinar do Direito da Criança e do Adolescente. A autora traz uma série de conceitos a respeito do que caracteriza este ser criança $e$ ser adolescente, explorando as visões jurídica, psicológica, sociológica e pedagógica sobre as crianças e adolescentes.

O reconhecimento do direito de ser adolescente é também o tema do mais recente relatório do Unicef sobre a situação dos adolescentes no Brasil ${ }^{401}$ :

\begin{abstract}
"O reconhecimento da importância dos processos de desenvolvimento que ocorrem na adolescência, da oportunidade que a adolescência representa para o País, do benefício que as vivências da adolescência representam tanto para sua vida presente quanto, posteriormente, para sua vida de adulto, resulta na afirmação de que esses meninos e meninas são detentores do direito de ser adolescente. O que significa, sob a ótica da cidadania, o direito de ter direitos, de conhecer seus direitos, de criar novos direitos, de participar da conquista dos seus direitos."
\end{abstract}

Assim é que, retomando o teor do artigo 16, os direitos de liberdade compreendem diversas liberdades que são parte integrante do que é ser criança e ser adolescente: liberdade de ir, vir e ficar, a liberdade de opinião e de expressão, a liberdade de crença $e$

\footnotetext{
${ }^{399}$ Com isso, não é exagero dizer que até mesmo o direito de decidir sobre como morrer se encontra garantido a crianças e adolescentes. Com variações, o que é evidente, conforme o caso concreto, em situações de doenças graves e/ou em estado terminal, por exemplo, crianças e adolescentes devem poder expressar sua opinião a respeito da realização ou não de tratamentos, mormente se forem inúteis e/ou estejam causando sofrimento extremo, quando não houver possiblidade de cura conforme os conhecimentos científicos e médicos atuais (situação caracterizada como ortotanásia). A realização de tratamentos inúteis e causadores de sofrimento (prática chamada de distanásia) não pode ser imposta a uma criança ou adolescente contra sua vontade, ainda que esta seja a vontade dos pais.

${ }^{400}$ SILVA PEREIRA, op cit, p. 43-70.

401 UNICEF. $O$ direito de ser adolescente: Oportunidade para reduzir vulnerabilidades e superar desigualdades. Brasília: UNICEF, 2011, p. 16.
} 
culto religioso, a liberdade de brincar, praticar esportes e divertir-se; a liberdade de participar da vida familiar e comunitária, sem discriminação; a liberdade de participar da vida política, na forma da lei; e a liberdade de buscar refúgio, auxílio e orientação.

E, como já se viu, as expressões acima não somente integram o direito à liberdade, mas também consubstanciam, junto com outros direitos, o direito à participação. Exercer a liberdade é, também, exercer o direito de ao desenvolvimento. E exercer a liberdade é, também, exercer o direito de participação - direito este necessário para o desenvolvimento.

Como afirmado, portanto, direito à participação e direito ao desenvolvimento (ou direito ao respeito à peculiar condição de pessoa em desenvolvimento) são indissociáveis.

A participação deve ser adequada a cada etapa do desenvolvimento - não se pode esperar que crianças participem da mesma forma que adolescentes. E, quando se fala em políticas de prevenção, não se pode esperar que a forma dessa prevenção, e seu conteúdo, seja idêntico para sujeitos em etapas diferentes do desenvolvimento.

\subsection{Crianças e adolescentes, sujeitos em desenvolvimento: caracterização biopsicossocial.}

Quais as expressões concretas do desenvolvimento infanto-adolescente em teremos neurológicos, sociais, psíquicos? E qual o papel da participação nesse processo?

Neste ponto, a preocupação é, primordialmente, identificar como se dá o desenvolvimento de forma comum a todas as crianças e adolescentes, independente de sua classe social, de sua cor, sexo ou local de nascimento ${ }^{402}$. Se a CIDC e o ECA são normas que partem da igualdade, é dela que se busca, também, partir.

\footnotetext{
${ }^{402}$ Não se desconsidera que as teorias, por terem sido elaboradas por pesquisadores ocidentais em países desenvolvidos e, portanto, baseadas naquela realidade, em um determinado momento histórico e fundadas em determinadas premissas filosóficas, podem não ser aplicáveis a todas as crianças do mundo. A contestação da validade dessas pesquisas, porém, escapa ao escopo do presente trabalho. Parte-se de tais trabalhos por serem considerados referências em suas áreas, e por terem dado origem a linhas de pesquisa e influenciarem, até hoje, pesquisadores e profissionais em todo o mundo.
} 
Para os fins deste trabalho, concentrar-nos-emos principalmente nas etapas do desenvolvimento que ocorrem a partir do início da alfabetização. Pesquisas recentes ${ }^{403}$ indicam que, antes da alfabetização, as crianças brasileiras usam o computador - mas menos a internet - com foco, principalmente, em jogos off-line, desenhos e outras atividades similares. Pouco utilizam a TIC para comunicação - exceto o celular, ao qual têm acesso desde muito cedo, mas que utilizam na maior parte das vezes para comunicarse por voz, não por escrito. Parecem também ter passar menos tempo acessando a TIC que crianças mais velhas.

Atualmente, é política nacional ${ }^{404}$ que uma criança a partir de 6 anos possa ingressar na primeira série do ensino fundamental. A interação por meio da TIC depende, em grande parte - mas não só - do uso da linguagem escrita. Assim, práticas como cyberbullying e crimes como o aliciamento on-line dependem da alfabetização para acontecer. Não se ignora que outras situações de risco podem acontecer mesmo que a criança, já usuária da tecnologia (falsos jogos infantis on-line podem ser um atrativo para sites de pornografia infantil, por exemplo), ainda não seja alfabetizada, mas entende-se que este risco diminui quanto menor a idade da criança.

As referências centrais para esta contextualização serão os estudos da psicologia do desenvolvimento, cujo teórico de referência é Jean PIAGET ${ }^{405}$. No Brasil, Yves de LA TAILLE $^{406}$ vem também desenvolvendo e coordenando estudos e obras de referência a respeito, contextualizando a teoria piagetiana na sociedade pós-moderna.

PIAGET surge como a referência natural porque, com seus estudos sobre desenvolvimento, o autor apresenta uma teoria a respeito do desenvolvimento cognitivo infantil que é referência mundial e que continua atual. Além disso, o autor relaciona as etapas do desenvolvimento cognitivo com o desenvolvimento moral.

\footnotetext{
${ }^{403}$ Pesquisa sobre o uso das tecnologias da informação e da comunicação no Brasil : TIC Crianças $2009=$ Survey on the use of information and communication technologies in Brazil : ICT Kids 2009 / [coordenação executiva e editorial/executive and editorial coordination, Alexandre F. Barbosa ; tradução/translation Karen Brito]. -- São Paulo : Comitê Gestor da Internet no Brasil, 2010. Edição bilíngue: português/inglês.

${ }^{404}$ Conforme dispõe o artigo $6^{\circ}$ da Lei 9.394 de 20 de dezembro de 1996 (Lei de Diretrizes e Bases da Educação Nacional), "É dever dos pais ou responsáveis efetuar a matrícula dos menores, a partir dos seis anos de idade, no ensino fundamental".

405 PIAGET, Jean. O juízo moral na criança. $3^{\text {a }}$ Ed. São Paulo: Summus, 1994; __. Problemas de Psicologia Genética. In: Piaget. Coleção Os Pensadores. Traduções de Nathanael C. Caixeiro, Zilda A. Daeir, Celia E.A. Di Pietro. São Paulo: Abril Cultural, 1978. 426p.

${ }^{406}$ LA TAILlE, Yves de. Moral e ética: dimensões intelectuais e afetivas. Porto Alegre: Artmed, 2006; Formação Ética: do tédio ao respeito de si. Porto Alegre: Artmed, 2009.
} 
O desenvolvimento cognitivo oferece o substrato necessário para fundamentar políticas de prevenção no tocante ao aspecto da avaliação de riscos e benefícios e da tomada de decisões. O desenvolvimento moral, por sua vez, se liga, primordialmente, à cooperação, elemento salutar na participação (em especial à participação coletiva), mas também tem seu papel importante na avaliação dos riscos e oportunidades e na tomada de decisões.

Serão também abordados aspectos do desenvolvimento sexual, que dizem respeito ao tema central deste trabalho, baseados em especial na psicanálise, teoria desenvolvida por Sigmund FREUD ${ }^{407}$.

A conjugação da abordagem não é nova: LA TAILLE, por exemplo, como se verá, faz um exercício de diálogo entre a teoria moral desenvolvida pela psicanálise e pela psicologia do desenvolvimento moral e, segundo VICENTIN, foram os “(...) saberes psicológicos, psicanalíticos e outros pedagógicos que, em alguma medida, subverteram o lugar de tutelada que a criança ocupou nos séc XVII e XIX e a inscreveram como "construtora de saber e sujeito de desejo" pela linha da psicologia do desenvolvimento, na concepção construtivista (Piaget) e pela linha da psicanálise (com a concepção de uma sexualidade e de um saber da criança: as teorias sexuais). Isso resultou num potente "misto" de saberes (diferente da cisão que persistiu por mais tempo no campo da saúde mental do adulto entre as diferentes áreas da saúde), que inscreve o "desenvolvimento infantil" numa possível transdisciplinaridade"408

Uma vez que esses desenvolvimentos (cognitivo, moral, sexual) acontecem de forma simultânea na criança e no adolescente, não haverá especial preocupação em sistematizá-los separadamente.

\footnotetext{
${ }^{407}$ FREUD, Sigmund. O Mal estar na civilização. Trad de José Otávio de Aguiar Abreu. Rio de Janeiro: . A Sexualidade Infantil In Obras psicológicas completas de Sigmund Freud: edição standard brasileira, Volume VII. Rio de Janeiro: Imago, 2006; O Ego e o Id In Obras psicológicas completas de Sigmund Freud: edição standard brasileira, Volume XIX. Rio de Janeiro: Imago, 2006; ABERASTURY, Arminda; KNOBEL, Mauricio. Adolescência Normal. São Paulo: Artmed, 1981.

${ }^{408}$ VICENTIN, Maria Cristina. Infância e adolescência: uma clínica necessariamente ampliada. Rev. Ter. Ocup. Univ. São Paulo, v. 17, n. 1, p. 10-17, jan./abr. 2006; p.14.
} 


\subsubsection{Desenvolvimento biopsicossocial da criança ${ }^{409}$}

Segundo a psicanálise, o desenvolvimento psicossexual do ser humano começa desde o nascimento. A interpretação psicanalítica considera que a pulsão de vida, também chamada de libido (Eros), é limitada pela pulsão de morte ou agressividade (Tânatos); as duas pulsões, juntas, são as responsáveis pela sobrevivência do indivíduo ${ }^{410}$.

A mesma pulsão de vida, energia que nos faz buscar, inicialmente, o alimento, o que garante a nossa sobrevivência, é a energia que, a partir da puberdade, impulsionará o sujeito para o exercício de sua sexualidade que, ao final, visa à reprodução e à manutenção da espécie humana.

O desenvolvimento psíquico saudável, segundo a psicanálise, passa, portanto, pelo desenvolvimento da sexualidade, na infância, também saudável. E o desenvolvimento moral também será, em parte, determinado pela integração adequada deste desenvolvimento da sexualidade na criança. "O desfecho do desenvolvimento constitui a chamada vida sexual normal do adulto, na qual a obtenção de prazer fica a serviço da função reprodutora, e as pulsões parciais, sob o primado de uma única zona erógena, formam uma organização sólida para a consecução do alvo sexual num objeto sexual alheio" ${ }^{411}$.

O exercício da libido se conjuga ao impulso mais natural que FREUD identifica no ser humano, denominado de Princípio do Prazer. Segundo esta ideia, o ser humano, desde a infância, busca o prazer, e em suas estruturas psíquicas iniciais, este é o único impulso existente: a criança busca a sobrevivência e logo identifica que a fonte de sobrevivência, a fonte de alimento, o seio da mãe, é também fonte de prazer ${ }^{412}$. O que limitará,

\footnotetext{
409 ECA: “Art. $2^{\text {o }}$ Considera-se criança, para os efeitos desta Lei, a pessoa até doze anos de idade incompletos, e adolescente aquela entre doze e dezoito anos de idade".

410 Ao mesmo tempo que pode se voltar contra o próprio indivíduo, de forma autodestrutiva (daí a explicação para a pulsão ser denominada de pulsão de morte), a agressividade é necessária para impulsionar grandes conquistas e até mesmo para lutar, efetivamente, pela sobrevivência física, em situações de ameaça. Daí a necessidade de canalizar a agressividade para a realização de coisas, do mesmo modo que é necessário sublimar a libido, já que a sua expressão desenfreada (rendição ao princípio do prazer) é socialmente inadequada (FREUD,. O Mal Estar..., p. 77).

${ }^{411}$ FREUD. A Sexualidade Infantil..., p. 186.

412 "No esforço de rastrear as origens da pulsão sexual, descobrimos até agora que a excitação sexual nasce (a) como a reprodução de uma satisfação vivenciada em relação a outros processos orgânicos, (b) pela estimulação periférica apropriada das zonas erógenas (...)”. Idem, ibidem, p. 189.
} 
posteriormente, a busca da realização do princípio do prazer a todo custo, será exatamente o desenvolvimento de uma estrutura psíquica de interdição, que se dividirá em dois aspectos: interdição a partir da adequação à realidade (Ego) e interdição a partir das regras morais (Superego).

O desenvolvimento psíquico saudável passa por 4 fases, relacionadas à principal fonte de prazer para a criança em desenvolvimento: oral, anal, fálica e genital. Esse desenvolvimento vai acontecendo de forma integrada ao desenvolvimento neurológico infantil. Inicialmente, até por não ter estruturas neurológicas e fisiológicas totalmente formadas, a criança não consegue distinguir de forma precisa o que ocorre ao seu redor. Somente enxerga com nitidez o que está a $30 \mathrm{~cm}$ de seus olhos ${ }^{413}$. Reconhece, principalmente, o cheiro da mãe, e relaciona-o com as sensações de conforto e prazer que ele lhe proporciona: calor, alimento, cuidado. A relação desta criança com o mundo se dá, portanto, pela boca: é com ela que se alimenta e é com o choro que consegue atrair a atenção de sua mãe. Sem o choro, e sem o alimento, a criança não sobreviveria. A partir do momento em que é capaz de pegar objetos com a mão, por volta dos 4 meses, a criança leva-os à boca, para "experimentá-los". Juntamente com isso, começa a experimentar vocalizações diversas, tentativas iniciais de comunicação falada.

O desenvolvimento neurológico é extremamente intenso nesse período inicial, pois muitas estruturas cerebrais ainda não estão formadas. O cérebro da criança ao nascer tem 1/3 do tamanho de um cérebro adulto.

É somente a partir do $6^{\circ}$ mês, que a criança consegue perceber-se como um ser diferente da mãe e, portanto, do mundo. Até os dois anos, a criança passará por uma série incrível de transformações, muito rápidas, que incluirão o desenvolvimento da capacidade de andar e falar. Emocionalmente, ocorrem intensas vivências, como a separação da mãe e do pai, a criação de uma relação de confiança com seus cuidadores, a identificação do 'humor' do ambiente e a reação a ele por meio do choro, da tranquilidade ou do riso.

A fase denominada por FREUD de oral vai desde o nascimento até a idade em que a criança começa, gradualmente, a controlar os esfíncteres - é o início da fase denominada

${ }^{413}$ MENTE \& CÉREBRO. O encanto e o desafio dos primeiros anos. In Mente \& Cérebro. Edição Especial: O mundo da infância. São Paulo: Duetto, p. 8. 
de anal ${ }^{414}$ que ocorre entre 2 e 3 anos de idade. A criança sente prazer na capacidade de controlar o seu corpo - é como se fosse, também, capaz de controlar o mundo. Nesta idade, a criança já anda com desenvoltura, e passa a ter capacidade de realizar uma série de tarefas sozinha.

O desenvolvimento das estruturas psíquicas denominadas por FREUD de Id, Ego e Superego se dá ao longo de toda a infância, acompanhando o desenvolvimento neurológico e social da criança. $\mathrm{Na}$ fase inicial, em que a criança não se identifica como separada no mundo, a única estrutura psíquica existente é o Id (isso), que é regido pelo princípio do $\operatorname{prazer}^{415}$. O desenvolvimento do Ego (eu) somente ocorre a partir do momento em que a criança se percebe como separada do mundo e de sua mãe.

As experiências de separação dos pais, as pequenas frustrações que vão acontecendo durante os primeiros anos do desenvolvimento (chorar, mas não conseguir o que quer, tentar andar e cair) vão sendo responsáveis pelo desenvolvimento de um senso, de um princípio de realidade: a criança percebe, então, que não basta chorar para conseguir tudo que se quer, que nem sempre será possível obter o que se deseja. Nesta fase, as birras são uma das formas mais comuns da criança chamar a atenção, o que se coaduna com a aprendizagem do senso de realidade (as birras costumam estar relacionadas com a frustração da criança e com a sua incapacidade de comunicar de forma eficaz). $\mathrm{O}$ princípio de realidade é necessário, entre outras coisas, para "capacitar para a defesa contra sensações de desprazer que realmente sentimos ou pelas quais somos ameaçados" ${ }^{\$ 16}$. Este senso de realidade ainda não é um senso moral, todavia.

Apesar de não ter início antes dessa fase ${ }^{417}$, o desenvolvimento do senso moral (e do Superego) se evidencia, segundo a teoria psicanalítica, a partir da vivência que ele

\footnotetext{
414 “A atividade é produzida pela pulsão de dominação através da musculatura do corpo, e como órgão do alvo sexual passivo o que se faz valer é, antes de mais nada, a mucosa erógena do intestino; mas há para essas duas aspirações opostas objetos que não coincidem”. FREUD, op cit., p. 187.

${ }^{415}$ Se lembrarmos que a criança, inicialmente, não consegue focar objetos a longa distância, a ideia de que a criança tem uma sensação de 'fusão' com o mundo faz ainda mais sentido.

${ }^{416}$ FREUD. O mal estar..., p. 13.

${ }^{417}$ Embora a capacidade de exprimir livremente as emoções e de experimentar seja considerada saudável, desde a tenra idade a criança precisa aprender a lidar com as suas emoções e de saber quais expressões e comportamentos são socialmente adequados, o que requererá a intervenção e exemplo dos pais, que representam a primeira fonte de informação sobre o dever moral.
} 
denomina de complexo de Édipo ${ }^{418}$. Esta vivência ocorre no período entre 3 e 4 anos de idade, concomitante à terceira fase da sexualidade infantil, denominada de fálica.

$\mathrm{Na}$ fase fálica, as crianças começam a identificar as diferenças entre os corpos de meninos e meninas. O autor identifica, nos meninos, um orgulho de possuir um pênis, e nas meninas a inveja do pênis (daí o nome da fase, fálica). Essa identificação de meninos e meninas como diferentes é acompanhada por sentimentos de desejo e rivalidade para com o pai e a mãe, ou as figuras que os representem. FREUD utiliza o mito grego de Édipo, que, sem saber, apaixona-se pela própria mãe, Jocasta, e mata seu pai para poder desposála, para ilustrar o processo que se inicia com um desejo sexual inconsciente pela mãe, na identificação do pai como opositor e que se resolve, normalmente, na identificação do menino com o pai e sublimação de seu desejo pela mãe A resolução positiva deste conflito seria determinante para o exercício de uma sexualidade saudável na vida adulta.

O exemplo utilizado pelo pai da psicanálise no ensaio "A Sexualidade Infantil", publicado na obra "Três Ensaios sobre a Teoria da Sexualidade" (1905), é o de uma criança do sexo masculino. No caso das meninas, o processo se daria de forma parecida, sendo a sua resolução saudável a identificação da menina com a mãe e sublimação de seu

\footnotetext{
418 "Em sua forma simplificada, o caso de uma criança do sexo masculino pode ser descrito do seguinte modo. Em idade muito precoce o menininho desenvolve uma catexia objetal pela mãe, originalmente relacionada ao seio materno, e que é o protótipo de uma escolha de objeto segundo o modelo anaclítico; o menino trata o pai identificando-se com este. Durante certo tempo, esses dois relacionamentos avançam lado a lado, até que os desejos sexuais do menino em relação à mãe se tornam mais inten sos e o pai é percebido como um obstáculo a eles; disso se origina o complexo de Édipo. Sua identificação com o pai assume então uma coloração hostil e transforma-se num desejo de livrar-se dele, a fim de ocupar o seu lugar junto à mãe. Daí por diante, a sua relação com o pai é ambivalente; parece como se a ambivalência, inerente à identificação desde o início, se houvesse tornado manifesta. Uma atitude ambivalente para com o pai e uma relação objetal detipo unicamente afetuoso com a mãe constituem o conteúdo do complexo de Édipo positivo simples num menino.

Juntamente com a demolição do complexo de Édipo, a catexia objetal da mãe, por parte do menino, deve ser abandonada. O seu lugar pode ser preenchido por uma de duas coisas: uma identificação com a mãe ou uma intensificação de sua identificação com o pai. Estamos acostumados a encarar o último resultado como o mais normal; ele permite que a relação afetuosa com a mãe seja, em certa medida, mantida. Dessa maneira, a dissolução do complexo de Édipo consolidaria a masculinidade no caráter de um menino. De maneira precisamente análoga, o desfecho da atitude edipiana numa menininha pode ser uma intensificação de sua identificação com a mãe (ou a instalação de tal identificação pela primeira vez) - resultado que fixará o caráter feminino da criança.

Se considerarmos mais uma vez a origem do superego, tal como a descrevemos, reconheceremos que ele é o resultado de dois fatores altamente importantes, um de natureza biológica e outro de natureza histórica, a saber: a duração prolongada, no homem, do desamparo e dependência de sua infância, e o fato de seu complexo de Édipo, cuja repressão demonstramos achar-se vinculada à interrupção do desenvolvimento libidinal pelo período de latência, e, assim ao início bifásico da vida sexual do homem". FREUD, S. O Ego e o Id In Obras psicológicas completas de Sigmund Freud: edição standard brasileira, Volume XIX. Rio de Janeiro: IMAGO, 2006; p 44-45.
} 
desejo pelo pai (Complexo de Elektra, conceito desenvolvido, posteriormente, por Carl Gustav Jung).

A resolução do complexo de Édipo traz em si um elemento importante de interdição moral, que é a proibição do incesto ${ }^{419}$. A partir da resolução do complexo de Édipo, o desenvolvimento sexual permanece latente até a puberdade, que será abordada adiante.

A partir da teoria freudiana, é possível identificar que o desenvolvimento da moral $^{420}$ não é possível sem a presença da instância psíquica denominada de Superego. O Superego é a sede da censura interna ${ }^{421}$, mas o conteúdo da moral é socialmente determinado $^{422}$. E o primeiro local de aprendizagem desses deveres morais é junto à família. É no seio da família, em especial a partir da figura do poder representada pelo pai, que a criança aprenderá, inicialmente, as noções de certo e errado, ao mesmo tempo em que se acostuma com as frustrações que advêm do princípio da realidade.

Todas essas mudanças são acompanhadas por crescente desenvolvimento neurológico e cognitivo. E, segundo PIAGET, o desenvolvimento cognitivo é fundamental

\footnotetext{
${ }^{419}$ Esta é uma das tantas razões pela qual se critica a teoria freudiana, pois o incesto é algo socialmente definido, e estudos antropológicos em sociedades não ocidentais indicam que nem sempre esta interdição ocorre da mesma maneira e com o mesmo significado que ocorria na sociedade europeia do final do século XIX e início do século XX, que foi observada por FREUD e cujo comportamento foi a base da sua teoria.

${ }^{420}$ Yves de LA TAILLE anota, contudo, que ao contrário da teoria piagetiana, a teoria freudiana não é considerada uma teoria do desenvolvimento moral, por prever somente dois momentos: um momento prémoral (fase pré-edípica), em que a criança não obedece porque teme a autoridade, mas sim por medo de perder a proteção e por medo do castigo (heteronomia ligada ao poder, e não à autoridade) e um momento em que se constitui a moral, a partir do qual a criança se identifica com a figura do poder (superação do complexo de Édipo e do medo da castração). FREUD não desenvolveu estudos que identificassem como se dá, eventualmente, uma 'evolução' em termos de comportamento moral pelo indivíduo, mas, em obras como "O Mal Estar na Civilização", busca explicar por mecanismos como sentimento de culpa, sublimação, renúncia ao instinto e outros como é possível, psiquicamente, sobreviver na sociedade civilizada, agindo de maneira moral (ao menos, perante aos olhos dos demais).

Outra diferença marcante entre a teorização sobre a moral de FREUD e de PIAGET é que, enquanto FREUD enfatiza a dimensão afetiva do comportamento moral (e não define o seu conteúdo, que é socialmente adquirido), PIAGET enfatiza sua dimensão racional e assimila a moral a princípios de igualdade, reciprocidade e justiça (LA TAILLE, Yves de. Moral e ética...p. 12).

${ }^{421}$ Note-se que o Superego pode exercer sobre o sujeito uma censura muito maior do que a socialmente necessária. Portanto, se a falta do Superego pode, pela teoria Freudiana, implicar em um sujeito incapaz de conviver segundo as regras morais sociais, um Superego 'mais desenvolvido' não significa necessariamente uma pessoa mais apta ao convívio social ou com sentimentos morais mais elevados (por exemplo, um sentimento de profunda compreensão pela humanidade ao invés de mesquinho). Significa, tão somente, que a instância censora interna é muito rígida - o que pode levar o indivíduo até ao isolamento social.

${ }^{422}$ Aí reside uma das consequências da crítica ao complexo de Édipo como processo necessário ao desenvolvimento do Superego e do senso moral. Imaginando-se uma sociedade em que o incesto não fosse proibido socialmente, por exemplo, o modelo do complexo de Édipo pode não fazer sentido. Não se poderia, porém, concluir que, por não passarem por este processo, seus habitantes não desenvolvem senso moral.
} 
para o desenvolvimento moral. Em seus estudos, este pesquisador observou essencialmente a construção da cognição por meio das respostas e atitudes de crianças em situações concretas de jogos e experiências. Concentrou-se, portanto, no estudo das estruturas lógicas, ou seja, na racionalidade.

Piaget divide o desenvolvimento cognitivo em etapas, que vão se construindo umas sobre as outras, formando uma estrutura. Isso significa que, para passar de um aprendizado para outro, é preciso tempo e conservação das estruturas anteriormente desenvolvidas. "Para que um novo instrumento lógico se construa, é preciso sempre instrumentos lógicos preliminares; quer dizer que a construção de uma nova noção suporá sempre substratos, subestruturas anteriores." ${ }^{423}$

Quatro etapas foram identificadas no desenvolvimento: a primeira etapa precede a linguagem e é chamada de inteligência sensório-motora, e se estende até os 18 meses (1 ano e meio).

A etapa que começa com a linguagem e vai até os 7 ou 8 anos é denominada de representação (etapa pré-operatória). Entre 7 e 12 anos, dá-se o período denominado de operatório concreto. Por fim, após os 12 anos, as operações proporcionais ou formais.

As idades em que essas etapas podem acontecer podem variar um pouco, mas é certo que, para atingir um certo estágio, “é necessário ter construído as pré-estruturas, as subestruturas preliminares que permitem progredirmos mais" ${ }^{\prime 424}$.

Durante o primeiro ano e meio de vida, a criança constrói todas as subestruturas que irão possibilitar o desenvolvimento da linguagem: "a noção do objeto, a do espaço, a de tempo, sob a forma das sequências temporais, a noção de causalidade, em suma as grandes noções das quais o pensamento se servirá ulteriormente, e que são elaboradas, empregadas pela ação material, desde o nível sensório-motor. ${ }^{" 425}$

Alguns exemplos fornecidos pelo autor são a incapacidade da criança, por exemplo, de identificar que um objeto, inicialmente visível, permanece onde estava após

\footnotetext{
${ }^{423}$ PIAGET, Jean. Problemas de Psicologia Genética. In: Piaget. Traduções de Nathanael C. Caixeiro, Zilda A. Daeir, Celia E.A. Di Pietro. São Paulo: Abril Cultural, 1978. (Os Pensadores); p. 215.

${ }^{424}$ Idem, ibidem.

${ }^{425}$ Idem, ibidem, p. 217.
} 
ser escondido: a criança perde o interesse pelo objeto ou encoleriza-se, caso aquele objeto seja importante pra ela.

PIAGET também descreve o desenvolvimento da noção de espaço na criança, que é gradual, e sempre centrado no próprio corpo (espaços egocêntricos), embora inicialmente a criança não consiga perceber o seu próprio corpo como um elemento que está contido em um espaço maior.

O primeiro ano e meio de vida "é talvez o período da infância em que as aquisições são mais numerosas e mais rápidas". Por volta de um ano e meio até 2 anos de idade, a criança passa para a fase denominada de pré-operatória. Podemos identificar o início desta fase com a fase do desenvolvimento sexual infantil que FREUD denomina de 'anal'. A partir deste período, a criança desenvolve a função simbólica, que se manifesta na sua capacidade de fantasiar e de representar simbolicamente os acontecimentos do mundo real. Junto com esse desenvolvimento vêm a capacidade de verbalizar e a consciência de si própria como separada do mundo. As competências de linguagem se desenvolvem ao mesmo tempo em que as competências físicas ${ }^{426}$.

A socialização da criança se inicia também nesta fase, denominada de préoperatória. Até o final desta fase e o início da fase operatório-concreta, a interação da criança com o mundo se dá principalmente por meio de ações. Na tenra infância ainda não há pensamento, pois ele só começa a se construir a partir da linguagem - e a criança só começa a falar as primeiras palavras, como se sabe, a partir de um ano de idade. ${ }^{427}$

O brincar é atividade que se inicia na fase operatório-concreta, sendo de fundamental importância para o desenvolvimento, seja quando é realizado pela criança sozinha, seja como atividade realizada em interação com seus pares. Considerado por WINNICOTT como atividade de possibilidades infinitas, baseado na aceitação de símbolos, o brincar "torna a criança capaz de experimentar tudo o que se encontra em sua

\footnotetext{
${ }^{426}$ Idem, ibidem, p. 218.

${ }^{427}$ A inteligência sensório-motora se inicia antes da linguagem, e segundo o autor, não existe pensamento sem linguagem. "A inteligência é a solução de um problema novo para o indivíduo, é a coordenação dos meios para atingir um certo fim (...); o pensamento é inteligência interiorizada e se apoiando não mais sobre a ação direta, mas sobre (...) a evocação simbólica pela linguagem (...) que permitem representar o que a inteligência sensório-motora, pelo contrário, vai apreender diretamente”. Idem, Ibidem, p. 216.
} 
íntima realidade psíquica pessoal, que é a base do sentimento de identidade em desenvolvimento" ${ }^{\prime 428}$.

Para WINNICOTT, um dos mais importantes sinais de saúde na criança é o surgimento e a manutenção do brincar construtivo (brincadeiras em que a criança, por exemplo, contribui para as atividades da casa e da família). Sem o brincar construtivo não surge o envolvimento, que se refere "ao fato de o indivíduo preocupar-se ou importar-se, e tanto sentir como aceitar responsabilidade" ${ }^{429}$. Para o desenvolvimento da capacidade de envolvimento, por sua vez, é necessário que a criança esteja inserida em um ambiente [familiar] suficientemente bom. O envolvimento emerge no começo de desenvolvimento emocional da criança, num período anterior ao do complexo de Édipo, processo que continua sendo fortalecido pelo crescimento nos anos subsequentes da infância.

Esse ambiente suficientemente bom implica na relação de confiança que se estabelece entre a criança e seus pais. A criança põe à prova esta confiabilidade, testando os pais, buscando se impor. Ela precisa sentir que, não obstante todas as suas tentativas de desestabilizar o lar, é amada. Ao mesmo tempo, precisa perceber que há uma autoridade no lar (em geral, exercida pelo pai). "Se o lar consegue suportar tudo o que a criança pode fazer para desorganizá-lo, ela sossega e vai brincar. ${ }^{430 " ~ S o m e n t e ~ a i ́ ~ a ~ c r i a n c ̧ a ~ p o d e ~ s e n t i r-s e ~}$ livre para ser irresponsável.

A fase operatório-concreta, última que podemos relacionar com a infância, se inicia por volta dos 7 anos. Na teoria psicanalítica, em termos do desenvolvimento sexual infantil, este momento se identifica com a fase de latência. FREUD identifica esta fase como um momento em que as crianças não expressam particular interesse pelo sexo oposto. Por outro lado, esta fase é caracterizada por PIAGET como um intenso período de socialização que é essencial para o desenvolvimento moral.

Não por acaso, PIAGET identifica o período até 4 anos de idade como uma fase de anomia, período no qual a “criança ainda não adentrou o universo moral. É verdade que,

\footnotetext{
${ }^{428}$ WINNICOTT, Donald W. Privação e Delinquência. Tradução Álvaro Cabral. $3^{\mathrm{a}}$ ed. São Paulo: Martins Fontes, 1999, p.109. Apesar do nome da obra, que é referência em para estudos de criminologia clínica, Winnicott não aborda somente as questões da relação entre privação e delinquência, debruçando-se, em diversos artigos e palestras (muitas delas proferidas para leigos e transmitidas por rádio), a respeito de diversas questões do desenvolvimento infantil.

${ }^{429}$ WINNICOTT, op cit, p. 111. Itálico no original.

${ }^{430}$ Idem, ibidem, p. 129.
} 
desde o nascimento, a criança é colocada em um universo de regras sociais. (...) Todavia, antes dos 4 anos, em média, as regras derivadas da moral ainda não estão associadas, para a criança, a valores como o bem e o mal, o certo e o errado. Seria melhor dizer que se trata de hábitos de conduta (...). Por volta dos 4 anos, a criança começa a conceber que há ações que devem ou não devem ser realizadas (...) [,] ações que são boas ou más, certas ou erradas. ${ }^{{ }^{431}}$ A partir deste momento, a criança entra no universo da moral, e da anomia, passa para a heteronomia ${ }^{432}$.

O período operatório-concreto se estende até os 11 ou 12 anos. O fato de o ensino formal (escolar) se iniciar mais ou menos no começo deste período (assim como o fato de a puberdade se iniciar ao final deste período, por volta dos 11-12 anos), não é coincidência, portanto. É preciso que a criança já tenha desenvolvido determinadas estruturas neurológicas e psíquicas, a capacidade de realizar certas operações lógicas, para que possa apreender certos conteúdos. É que as noções mais elaboradas de conservação de substância, peso, a capacidade de classificar elementos (flores x rosas, por exemplo) e de ordená-los de forma seriada e outras operações lógicas mais complexas só são adquiridas a partir dos 7 anos de idade, segundo PIAGET ${ }^{433}$.

No desenvolvimento moral, a cooperação se apresenta como um conceito central na teoria de PIAGET, sendo essencial para o caminhar da heteronomia para a autonomia. A heteronomia moral é regida por relações de coação, cujas regras são postas de antemão. São relações assimétricas, sendo que não é facultado aos participantes modificar as regras. Não existe reciprocidade. No caso das crianças, a relação de coação reforça o egocentrismo e não lhes possibilita a construção das estruturas mentais operatórias necessárias à conquista das relações de reciprocidade.

As relações de cooperação, por outro lado, são

\footnotetext{
${ }^{431}$ LA TAILLE, Yves de. Moral e ética..., p. 97.

${ }^{432}$ Heteronomia e autonomia são dois conceitos centrais para as teorias do desenvolvimento. A heteronomia é a condição de quem age de acordo com as regras impostas ou determinadas por outrem. Toda criança é heterônoma, e esse é o estágio de desenvolvimento inicial inescapável, já que, sem alguém que ensine quais são as regras e que estabeleça que elas devem ser cumpridas, não é possível chegar, depois, à autonomia. A autonomia será a condição do sujeito moral que é capaz de avaliar as normas já existentes, propondo outras e, especialmente, agindo a partir de seu próprio conjunto de regras morais. Para Piaget, o ponto final natural do desenvolvimento moral é a autonomia, apesar de a heteronomia ser um ponto de partida inescapável. Idem, ibidem, p. 97.

${ }^{433}$ PIAGET, op. cit., p. 220.
} 
"simétricas, portanto, regidas pela reciprocidade. São relações constituintes, que pedem, pois, mútuos acordos entre os participantes, uma vez que as regras não são dadas de antemão. Somente com a cooperação o desenvolvimento intelectual e moral pode ocorrer, pois ele exige que os sujeitos se descentrem para poder compreender o ponto de vista alheio. No que tange à moral, da cooperação derivam o respeito mútuo e a autonomia. Para Piaget, as relações entre as crianças promovem a cooperação, justamente por se configurarem como relações a serem constituídas entre seres iguais." ${ }^{434}$

Nesse percurso, o desenvolvimento intelectual - e, portanto, a racionalidade - se dá em paralelo ao desenvolvimento moral. "Sem operações lógicas, o ideal moral da reciprocidade (típico da autonomia) não seria possível, uma vez que a criança pequena, por falta de pensamento reversível, ainda não concebe operatoriamente a reciprocidade." Por esta razão, somente a partir dos 07 anos, quando a criança atinge o estágio operatórioconcreto, e passa compreender a noção de reversibilidade, é que ela será capaz de compreender a reciprocidade, necessária para a construção de uma moral autônoma ${ }^{435}$.

Será determinante o tipo de relação ao qual a criança é exposta, para a construção de uma moral autônoma ou heterônoma:

\footnotetext{
"se as relações sociais forem essencialmente assimétricas, nas quais mandam uns e outros obedecem, a moral heterônoma prevalece. Em compensação, se as relações forem simétricas, baseadas na reciprocidade, e na cooperação, a moral autônoma pode nascer e desabrochar. É por esta razão que Piaget sempre deu muita importância às relações sociais entre as crianças: o fato de elas serem iguais entre si favorece a construção da moral autônoma (...). Para Piaget, cooperação é condição imprescindivel para o desenvolvimento cognitivo e moral".
}

$\mathrm{Na}$ base de todo este processo estão intensas transformações cerebrais, que incluem o estabelecimento de conexões funcionais entre os neurônios, eliminação de conexões formadas em excesso que não tenham utilidade e a formação da capa de mielina nas fibras

434 . Desenvolvimento do juízo moral. In Viver Mente\&Cérebro. Coleção Memória da Pedagogia. Vol 1 Jean Piaget. p. 76-88; p. 83.

435 LA TAILLE, Yves de. Moral e ética..., p. 17; p99. 
que conectam os neurônios, o que "torna a transmissão de sinais mais rápida e confiável. As experiências vividas - desde a simples estimulação sensorial até as regras de convivência social aprendidas de pais e educadores - dão direção às alterações no sistema nervoso e moldam o cérebro e, com ele, o comportamento, ao longo de toda a primeira década de vida" ${ }^{436}$.

Refletindo sobre resultados de pesquisa sobre valores realizada com adolescentes, já mencionada na Parte I deste trabalho, TOGNETTA e VINHA asseveram que "o desenvolvimento da moralidade está relacionado à qualidade das interações que se apresentam nos ambientes sociais nos quais o indivíduo interage, se cooperativos ou autoritários" ${ }^{437}$. E a escola, que seria um importante ambiente a promover esta interação, ao contrário, requer que os alunos sejam "bem comportados", tranquilos, submissos, passivos e obedientes.

Fica clara, espero, a partir desta breve (e, aos olhos tanto de um estudioso da psicanálise quanto da psicologia do desenvolvimento, certamente muito incompleta) explicação sobre o desenvolvimento infantil, o quanto a participação é fator crucial nesse processo. Tanto para o desenvolvimento da sexualidade, quanto para o desenvolvimento cognitivo e moral, participar é fundamental, seja em casa, relacionando-se com os familiares, seja na escola, brincando, aprendendo, jogando com os seus pares. Este processo tem como meta final um sujeito autônomo, capaz de compreender, analisar, e, eventualmente, contestar as regras sociais vigentes, e a partir desse cotejo, tomar decisões e agir com base nestas decisões.

Espera-se, ainda, que até aqui esteja claro o que significa, em parte, considerar-se a criança (e, como veremos a seguir, o adolescente), um sujeito de direitos que se encontra em condição peculiar de desenvolvimento.

\subsubsection{Desenvolvimento biopsicossocial do adolescente}

O início da adolescência é identificado com o início aproximado da puberdade. A puberdade pode se iniciar antes ou depois dos 12 anos de idade, que é a data legalmente

\footnotetext{
${ }^{436}$ HOUZEL, Suzana Herculano. Novas Equações Cerebrais. In Revista Viver Mente \& Cérebro, O Olhar Adolescente, Vol. 1 - Corpos em Transição. Ed. Especial. São Paulo: Duetto; p. 27-35.

${ }^{437}$ TOGNETTA e VINHA, op cit. p. 39.
} 
atribuída, pelo ECA, como sendo o início da adolescência (artigo $2^{\circ}$ ). Em termos jurídicos, a mudança de status de criança para adolescente implica em uma série de consequências. Talvez a mais conhecida delas seja o fato de que, a partir dos 12 anos, no Brasil, uma pessoa passa a ser passível de responsabilização cível e criminal, por danos causados a outrem, podendo, por exemplo, cumprir medida socioeducativa judicialmente imposta no caso da prática de fatos tipificados como crime pelo direito penal (arts. 103 a 105 do ECA). Do mesmo modo, passa a usufruir de maior liberdade, podendo viajar por todo o território nacional, sem a necessidade de companhia ou autorização formal dos responsáveis (art. 83 do ECA).

No ECA, esta mudança de status, portanto, se dá em um contexto de autonomia progressiva $^{438}$, ou seja, quanto mais autonomia se dá ao sujeito em desenvolvimento (para decidir sobre assuntos de seu interesse, como é o caso da já mencionada adoção), mais responsabilidade ele passa a assumir perante terceiros por suas ações e omissões.

Todavia, se, por um lado, já tem capacidade para formular opiniões e assumir responsabilidades, por outro lado, o adolescente levará, ainda, muitos anos para completar seu desenvolvimento, razão que justifica, entre outros dispositivos, a manutenção da responsabilidade penal juvenil aos 18 anos de idade.

A opção legislativa pelos termos inicial e final da adolescência entre os 12 e 18 anos parece ser baseada nas descobertas científicas a respeito do desenvolvimento. Vejamos.

O processo de passagem da infância para a adolescência, em realidade, se inicia entre 6 e 8 anos de idade; bem antes da idade juridicamente estabelecida, pois. Esta parece ser a razão pela qual Piaget estabelece a idade de 7 anos como uma idade de 'corte' para o desenvolvimento cognitivo, como visto acima.

A transformação no corpo do adolescente se inicia com mudanças neurológicas ${ }^{439}$, dentre elas no hipotálamo, estrutura "responsável por promover ajustes fisiológicos de

\footnotetext{
${ }^{438}$ MACHADO, Martha de Toledo. Proibições de excesso e proteção insuficiente no direito penal: as hipóteses dos crimes sexuais contra criança e adolescentes. São Paulo: Editora Verbatim, 2008, P. 170-175.

${ }^{439}$ Uma descrição detalhada deste processo pode ser lida em MANNA, Thais dela. "Hormônios em ação" In Revista Viver Mente \& Cérebro, O Olhar Adolescente... Vol I, p. 18-25 e em HOUZEL, Suzana Herculano; op cit.
} 
vários tipos pelo corpo afora - entre eles os hormonais" ${ }^{\text {"40 }}$. É a partir de um 'disparo' do hipotálamo que a glândula hipófise terá um aumento na produção e secreção de hormônios sexuais. As transformações no corpo, que passa a ganhar contornos e relevos diferentes (crescimento dos seios nas meninas, dos órgãos genitais nos meninos e aparecimento de pelos pubianos em ambos), são acompanhadas por crescimento acelerado dos ossos, ganho de massa muscular e de gordura, em um ritmo que só é superado pelo desenvolvimento da criança no período neonatal ${ }^{441}$.

Porém, a 'culpa' por toda a gama de comportamentos que os adolescentes passam a exibir durante o período não pode ser atribuída somente aos hormônios sexuais. Para que isso aconteça, inúmeras outras mudanças neurológicas foram necessárias para preparar o corpo, e muitas outras acompanharão este processo intenso.

Estas intensas mudanças implicam na necessidade de adaptação: a um novo corpo e a um novo papel na sociedade, na família, na escola. "Enquanto espicham, os adolescentes adquirem duas características da idade: tornam-se estabanados e começam a passar horas na frente do espelho. A razão mais provável para ambas as coisas é que o cérebro se vê subitamente obrigado a ajustar seus mapas sensório-motores à nova realidade corporal, com muitos centímetros a mais de altura e novas proporções." ${ }^{442}$

HOUZEL sugere que olhar-se tanto no espelho pode ser justamente uma maneira de oferecer ao cérebro uma oportunidade de "avaliar visualmente as novas proporções corporais e fazê-las casar com a realidade somestésica". Essas alterações físicas ocorrem na mesma época em que ocorre uma 'limpeza sináptica' no córtex parietal, parte do cérebro que contém estruturas responsáveis pelo alinhamento entre as várias percepções corporais, o que leva a supor que o processo de adaptação ao novo corpo é acompanhado por limpeza das conexões que representavam o esquema do corpo infantil. ${ }^{443}$

\footnotetext{
${ }^{440}$ HOUZEL, op cit., p. 32.

${ }^{441} \mathrm{O}$ "estirão", crescimento acelerado característico da fase se inicia no sexo feminino mesmo por volta dos 9,5 anos de idade e, nos meninos, a partir dos 10 anos e meio. Em média, 20\% da estatura final e 50\% do peso adulto são ganhos na adolescência.

${ }_{442}^{4}$ HOUZEL, op cit.; p. 33

${ }^{443}$ Idem, ibidem.
} 
Em termos psicanalíticos, esse processo se identifica com um período de elaboração de luto pela perda do corpo infantil, ao mesmo tempo em que se dá a elaboração do "luto pelo sexo oposto perdido neste processo evolutivo"

FREUD identifica a puberdade como o momento em que o sujeito atinge a maturidade sexual. No desenvolvimento da sexualidade, esta fase, chamada de genital, acontece na adolescência, após o período de latência.

Enquanto na fase fálica há uma relação de "oposição" entre meninos e meninas, seguida por uma fase em que há, aparentemente, certo desinteresse por crianças do sexo oposto e canalização da energia sexual para atividades intelectuais, e esportivas, o companheirismo e a amizade (fase de latência), a fase genital marcará o momento em que os adolescentes passarão a buscar o parceiro do sexo oposto, aceitando a sua genitalidade.

KNOBEL indica que as atividades de cunho sexual que se iniciam com a puberdade têm caráter exploratório e preparatório, diferindo do que se poderia chamar de uma relação genital madura e voltada à procriação. Os primeiros exercícios da sexualidade se iniciam aos 12 ou 13 anos - ou até mesmo logo antes disso. Apesar de, atualmente, serem considerados precoces, correspondem ao momento de amadurecimento que já está acontecendo em nível neuronal, hormonal, corporal etc.

Este exercício de sexualidade evolui do autoerotismo (expresso pelas primeiras práticas de masturbação) para atividades lúdicas que levam à exploração e à aprendizagem, também lúdica, do outro sexo, por meio de jogos, brincadeiras, toques, atividades sociais ${ }^{445}$. Nem sempre há um direcionamento claro com relação à escolha do objeto sexual, o que leva, muitas vezes, a práticas que podem assustar os adultos. Exemplifico: na década de 1980, eram populares os 'bailinhos', momentos de exercício das primeiras experimentações de aproximação sexual entre adolescentes, que se reuniam para dançar, normalmente em festinhas de aniversário. Brincadeiras e jogos (comuns ainda hoje) em que a 'punição' para a resposta errada é ganhar um beijo ou um abraço de um

\footnotetext{
${ }^{444}$ KNOBEL, Maurício, A Síndrome da Adolescência Normal In ABERASTURY, Arminda; KNOBEL, Mauricio. Adolescência Normal: Um enfoque psicanalítico. São Paulo: Artmed, 1981. 96 p; p. 45.

${ }^{445}$ KNOBEL, op. cit., p. 46. Sobre a prática de beijos entre meninas: BERGAMO, Giuliana. Meninas que beijam meninas. Revista Veja, ed 1844, 10 de março de 2004. Disponível em http://veja.abril.com.br/100304/p_088.html, consulta em 10/12/2011.
} 
colega - em geral do sexo oposto - também eram parte da diversão nas festinhas de adolescentes. Aparentemente, nada muito assustador para um pai ou uma mãe zelosos.

A partir dos anos 2000, notadamente nas grandes cidades, adolescentes do sexo feminino têm incluído nestas experimentações práticas como beijos e carinhos em outras meninas. A revista "Veja" publicou, em sua edição 1844, uma reportagem a respeito. Segundo a reportagem, tornaram-se comuns nas saídas de escola, na praia e nas portas de discotecas cenas de meninas de 13 a 17 anos andando de mãos dadas, e trocando "selinhos". "Em ambientes menos públicos, algumas delas podem ir mais além e se beijar na boca - beijo de verdade. É natural que muitos pais se perguntem o que, afinal de contas, está ocorrendo. A resposta é simples: nada. Para a esmagadora maioria das meninas que beijam meninas, essas atitudes não passam de curtição. Uma enquete realizada pelo site da revista Capricho, uma publicação destinada a mocinhas na faixa que vai dos 15 aos 17 anos, revela que 30\% das garotas já beijaram outra garota na boca. E quem beija, beija, principalmente, por farra e curiosidade. Elas não se consideram bi nem homossexuais. Não costumam fazer carinhos em alguém que acabaram de conhecer. É amiga com amiga e raramente as duas fazem mais do que beijar na boca."

Essas práticas podem parecer chocantes aos pais, que também têm dificuldades em lidar com a própria sexualidade, o que pode fazer com que a questão do desenvolvimento sexual e suas práticas tornem-se um importante ponto de conflito entre adolescentes e suas famílias. Também nas escolas há uma notória dificuldade em lidar com essas questões. Em ambas as instituições, as soluções adotadas podem ser, simplesmente, proibir os filhos ou alunos de namorar, o que, além de não solucionar a questão, pode acabar por estimular práticas arriscadas ou precipitadas, além de contribuir para a manutenção do ainda existente tabu a respeito da sexualidade.

Não é à toa que a sexualidade e suas expressões acabam sendo, quase sempre, encaradas como um problema, como expressa KNOBEL: "Temos aqui também o problema da curiosidade sexual, expressa no interesse pelas revistas pornográficas, tão frequente entre os adolescentes. ${ }^{, 46}$. Se, na década de 80 , em que a obra foi publicada pela

\footnotetext{
${ }^{446}$ KNOBEL, Maurício, op. cit., p. 46. Chamo a atenção para o fato de o autor se referir à curiosidade por revistas pornográficas como um 'problema'. Trata-se, em minha opinião, de natural manifestação da curiosidade a respeito do corpo do sexo oposto. Vale notar ainda que a obra, editada pela primeira vez em 1981, ainda se referia à revista como o meio de 'informação' a respeito do corpo feminino (a maioria
} 
primeira vez, a prática de adolescentes olharem juntos revistas "de mulher pelada" compradas com a cumplicidade do jornaleiro ou surrupiadas/emprestadas de pais ou irmãos mais velhos, assim como, a partir da introdução do aparelho de videocassete nas casas de alguns privilegiados, assistirem juntos, escondidos dos pais e mães, filmes eróticos ou pornográficos alugados na locadora do bairro, poderia se constituir em um 'problema', ele parece irrisório ante ao amplo e irrestrito acesso a cenas de práticas de sexo explícito de todos os tipos que a internet, hoje, proporciona.

Enquanto na televisão busca-se limitar o acesso a esses filmes com as regras de classificação indicativa ${ }^{447}$, na internet, exceto pelos filtros que bloqueiam o acesso a sites com conteúdo sexual, o acesso é simples, rápido e abundante, sem qualquer tipo de limitação. Basta clicar "sim" como resposta à pergunta "você tem mais de 18 anos?" ou digitar uma data de nascimento fictícia - qualquer adolescente sabe fazer esta conta - para acessar diversos sites com esses conteúdos.

Desse modo, os contatos com as imagens e representações da sexualidade na mídia, hoje, muitas vezes se dão em um "vôo sem escalas dos desenhos animados infantis às apimentadas cenas eróticas do filme pornô. Sem outras referências, sem um acervo de leitura de romances com os quais diluir e relativizar esta imagem da sexualidade, muitos acreditam que $\mathrm{o}$ ato sexual entre duas pessoas comuns se reveste das mesmas características que veem na telinha do computador." ${ }^{448}$

A mesma autora faz um alerta, referindo-se ao início das práticas de sexualidade nos adolescentes da geração digital: "O universo da sexualidade é o universo da ética, pois é a área da relação com o outro. Só se deveria entrar nesse universo depois de estabelecido

esmagadora das revistas pornográficas é voltada ao público masculino); atualmente, a internet oferece milhares de sites facilmente acessíveis por qualquer adolescente, onde é possível não só ver fotografias, mas também assistir a imagens de sexo de qualquer tipo, a qualquer momento e em qualquer lugar.

${ }^{447}$ A Classificação indicativa é “a indicação à família sobre a faixa etária para a qual obras audiovisuais (programação de TV, filmes, DVD, jogos eletrônicos e de interpretação - RPG) não se recomendam. A Classificação vincula a faixa horária à etária na televisão." Tem embasamento legal "na Constituição Federal, no Estatuto da Criança e do Adolescente, nas Portarias MJ n 1.100/2006 e n ${ }^{\circ} 1.220 / 2007$ e no Manual da Nova Classificação Indicativa (Portaria SNJ n ${ }^{\circ}$ 8/2006). A Portaria MJ no 1.100/2006 regulamenta a Classificação Indicativa de diversões públicas, especialmente obras audiovisuais destinadas a cinema, vídeo, DVD, jogos eletrônicos e de interpretação (RPG) e as Portarias MJ n ${ }^{\circ} 1.220 / 2007$ e SNJ n $^{\circ}$ 14/2009 regulamentam as obras audiovisuais destinadas à televisão". Fonte: http://pfdc.pgr.mpf.gov.br/atuacao-e-conteudos-de-apoio/publicacoes/comunicacao/guia-pratico-daclassificacao-indicativa

${ }^{448}$ ARATANGY, Lidia Rosenberg. Adolescentes Na Era Digital. São Paulo: Benvirá, 2011; p. 42. 
e internalizado um código de ética - o que não acontece antes da conquista do pensamento abstrato (...). A questão não está na idade cronológica, mas na intenção com que são feitos esses contatos e a atitude dos envolvidos. Fatos assustadores podem acontecer quando jovens adentram esse universo usando o poder da internet, sem antes estabelecer um compromisso com a ética" ${ }^{449}$.

A autora se refere, é evidente, às já mencionadas práticas de sexting e cyberbullying que podem acontecer no âmbito do processo de socialização de adolescentes que se dá simultaneamente on e off-line. Também se sabe que a reação e os efeitos potenciais dessas situações de conflito variam conforme a estrutura psíquica de cada adolescente, e dependerá, também do apoio, da orientação e do encaminhamento que pais e educadores deram a cada situação concreta. Não se pode desprezar, também o apoio dos próprios pares, a troca de experiências e de estratégias para enfrentar as situações de conflito (participação).

Para ilustrar as intensas mudanças pelas quais passam adolescentes em busca de sua identidade, inclusive no tocante à sexualidade, utilizarei a história de Patrícia ${ }^{450}$, adolescente do sexo feminino cujo desenvolvimento pude acompanhar a uma certa distância.

Na pré-adolescência, Patrícia era uma menina que não se destacava das demais: tinha cabelos, roupas, atitudes e interesses parecidos com os de dezenas de outras meninas de sua idade, da mesma escola ou do mesmo prédio. Quando ingressou na adolescência, não sei precisar ao certo a idade, cortou um pouco os cabelos e passou a usar roupas e acessórios bastante femininos, mas ainda com um toque infantil, como saias curtas e blusas com motivos de desenhos japoneses (mangás), além de maquiagem. Nesse momento, ela já se destacava das demais adolescentes de sua idade.

Um dia, perguntei a que "tribo" eu sou Emo ${ }^{452}$, mas não sou". Ela me contou, ainda, que frequentava a Galeria do Rock,

\footnotetext{
449 ARATANGY, op cit, p. 58.

${ }^{450}$ Nome fictício. A história é baseada puramente em observações não clínicas ou científicas, resultantes de relação de vizinhança, e tem cunho ilustrativo.

${ }^{451}$ Apropriado no uso cotidiano, atribui-se a expressão "tribos urbanas" a Michel MAFFESOLI, sociólogo francês que passou a usá-lo a partir de 1985 para designar novas formas de associação entre os indivíduos nas sociedades urbanas pós-modernas.
} 
tradicional ponto de encontro de diversas tribos urbanas da cidade de São Paulo. Mais adiante, ela pintou parte de seu cabelo de cor-de-rosa. Alguns meses mais, raspou a parte lateral dos cabelos e a nuca, mas ainda deixou o restante com um corte feminino.

Gradativamente, a adolescente começou a mudar o seu estilo de se vestir e a usar maquiagem mais forte nos olhos, oscilando entre um visual "dark" e "fofo". Um dia, depois de alguns meses sem encontrá-la, levei um choque: ao vê-la de costas, achei que era um menino. Demorei a identificá-la nas calças largas e camiseta. Tinha o cabelo curto, como a maior parte dos meninos usa. Fez tatuagens, começou a fumar. Patrícia era a personificação da "adolescente rebelde em busca de sua identidade".

Tempos depois, voltou a se vestir como menina. Em conversas de elevador, disseme que estava fazendo curso de modelo, e publicava muitas fotos com as amigas em redes sociais on-line (na época, faziam sucesso os fotologs ${ }^{453}$, blogs onde se publicavam, primordialmente, fotos, e a rede social Orkut). Deixou novamente o cabelo crescer. Já no final da adolescência, me pareceu que ficou mais à vontade em algum grupo urbano que identifiquei como "da moda" ou "descolados". Disse que ia estudar moda e passou a adotar um visual moderno ao se vestir e a usar cortes de cabelo assimétricos característicos dos "descolados".

Ao longo de todo este processo de busca de sua identidade e de sua 'tribo', que se estendeu praticamente por toda a sua adolescência, também observei que Patrícia experimentava sua sexualidade, pois eu a via, com frequência, nas imediações do condomínio, em situações que denotavam intimidade com outras meninas. Parecia, portanto, estar experimentando uma relação homossexual ${ }^{454}$ - o que faz sentido, considerando que durante certo período ela se vestia como um menino. Talvez, durante o processo, ela tenha percebido que não é preciso se vestir como um homem para vivenciar uma relação afetiva com outra mulher, ou pode não ter se sentido confortável na

\footnotetext{
${ }^{452}$ Emo é uma "tribo urbana" usualmente integrada por adolescentes e pré-adolescentes, cujo nome vem de "Emocore" (emotional hardcore ou hardcore melódica, um tipo de música derivada do punk hardcore). Os Emos são conhecidos, entre outras características, por sua sensibilidade e emotividade, experimentação da sexualidade; são identificáveis pelo uso de cabelo liso, com franja caindo sobre os olhos, muitas vezes colorido (azul, rosa, verde), maquiagem (mesmo os membros do sexo masculino usam lápis preto nos olhos) e roupas (tênis coloridos e roupas pretas).

${ }^{453}$ Cf. Glossário.

${ }^{454}$ Apesar de desejável, não será abordada aqui a questão específica do processo de desenvolvimento de adolescentes cuja orientação sexual seja a homossexualidade. Trata-se de importante problematização que, todavia, escapa ao âmbito deste trabalho.
} 
experiência de troca de gênero. Segundo KNOBEL, "é normal que, na adolescência, apareçam períodos de predomínio de aspectos femininos no rapaz e masculinos na moça. É preciso ter sempre presente o conceito de bissexualidade e aceitar que a posição heterossexual adulta exige um processo de flutuações e aprendizagem em ambos os papéis" ${ }^{455}$.

Não posso dizer quais os conflitos interiores acompanharam as mudanças exteriores de Patrícia; não a conheci o suficiente para saber. As transformações externas, porém, que em alguns momentos foram radicais, indicavam que havia intensas mudanças acontecendo em seu íntimo. Não podemos nos esquecer, também, que a maneira como nos apresentamos para o mundo determina, em grande parte, a maneira como seremos olhados e tratados ${ }^{456}$; mudanças na aparência, desse modo, podem indicar o desejo de provocar uma mudança no olhar do outro sobre si (e, como consequência, a mudança do próprio olhar sobre si mesmo).

A história de Patrícia é uma observação que ilustra esse momento de passagem, mas Patrícia não é só uma adolescente em busca de uma forma de expressar sua sexualidade. Como todos os adolescentes, ao mesmo tempo em que experimentava a sexualidade, Patrícia experimentava novos aprendizados, novos desafios sociais, enfrentava as próprias expectativas e frustrações e as de seus pais, sonhava com seu presente e seu futuro, e buscava os caminhos para chegar lá. Ela é um ser humano complexo e completo, em processo de desenvolvimento integral ${ }^{457}$.

Voltemos a atenção, agora, para outros aspectos do desenvolvimento do adolescente, ainda não abordados.

Em termos de desenvolvimento cognitivo, como já dito, o adolescente se encontra na fase que PIAGET denominou de operatório formal, que se inicia por volta dos 11 ou 12 anos, coincidindo, portanto, com a idade que fixa, legalmente, o início da adolescência.

\footnotetext{
${ }^{455}$ KNOBEL, Maurício, A Síndrome da Adolescência Normal In ABERASTURY, Arminda; KNOBEL, Mauricio. Adolescência Normal: Um enfoque psicanalítico. São Paulo: Artmed, 1981. 96 p; p. 48.

${ }^{456}$ A teoria da reação social, que na Criminologia é representada, entre outros, por Howard BECKER (“Outsiders") e Erving GOFFMAN ("Estigma"), identificou, por exemplo, que a atribuição social do caráter de desviante a um sujeito decorre, em parte, de sua aparência.

${ }^{457}$ Lembrando, sempre, que as diferenças entre as histórias de vida de cada adolescente serão determinadas por inúmeros fatores: sociais, psicológicos, econômicos, geográficos, de raça, de gênero etc.
} 
Progressivamente, o adolescente passa a desenvolver as operações de raciocínio abstrato. Isso significa a possibilidade passar a raciocinar a respeito de situações hipotéticas, por exemplo. De ponderar riscos e benefícios, e de tomar decisões com base nesta avaliação, inferindo as consequências. Esta é uma importante e necessária mudança rumo a um ser humano autônomo e responsável.

O pensamento abstrato, portanto, é o que caracterizará a maior conquista desta etapa: “a lógica do adolescente - e nossa lógica - é essencialmente uma lógica do discurso. Quer dizer que somos capazes - e o adolescente se torna capaz desde os 12 ou 15 anos - de raciocinar sobre enunciados verbais, proposicionais; somos capazes de manipular hipóteses, de raciocinar a partir do ponto de vista de um outro (...). Somos capazes de manipulá-las de uma maneira formal e hipotético-dedutiva" ${ }^{458}$.

É evidente que esta mudança é uma das principais razões que levou o legislador brasileiro a optar pela idade de 12 anos como a idade mínima para a responsabilização de seres humanos pela causação de danos a outrem. Como, porém, o desenvolvimento aos 12 anos não está completo, nada mais natural que estabelecer um sistema à parte para que respondam, chamado por alguns, atualmente, de Direito Penal Juvenil.

Alguns dos conceitos mais comuns a respeito dos adolescentes dizem respeito exatamente a estas questões: "adolescentes sabem exatamente o que estão fazendo" (bastante utilizados pelos defensores da redução da maioridade penal) ou "eles não têm controle de seus impulsos" e/ou "não são capazes de tomar decisões e fazer escolhas" (bastante utilizado em concepções vitimizadoras a respeito de adolescentes, especialmente por alguns defensores dos direitos de vítimas de abuso/exploração sexual).

Utilizadas em um discurso dicotômico quase esquizofrênico, essas definições são levadas ao extremo dependendo do que se deseja defender: punição para adolescentes infratores? Mas é claro, eles sabem exatamente o que estão fazendo! Devem, portanto, ser punidos como adultos. Proteção para vítimas de abuso sexual? Mas é claro, são puros e inocentes, não sabem o que estão fazendo, precisam ser protegidos! Punição máxima para os abusadores! 
Estas visões desconsideram a imensa gama de nuances que compõem o que é ser adolescente. Elas fazem parte de discursos prontos recheados de preconceitos e que são amplamente utilizados para justificar a elaboração de normas penais cada vez mais repressoras. Como todo discurso conservador, desconsideram toda e qualquer complexidade. E complexidade é uma palavra bastante adequada para caracterizar a vivência do adolescente, em especial na sociedade de hoje.

Vale a pena, ainda, pontuar algumas das características tradicionalmente atribuídas à adolescência, nos discursos do senso comum, características estas que, quase sempre, vêm acompanhadas de uma avaliação negativa. Segundo ARATANGY, é possível notar na sociedade um "preconceito contra o adolescente, alimentado pelos meios de comunicação e endossado por muitas escolas e até por especialistas (...). Há má vontade em ouvi-los e atribuem-lhe características (impulsividade, egoísmo, alienação) que em geral são falsas - ou, quando verdadeiras, não são prerrogativas exclusivas dos adolescentes. ${ }^{259}$

Assim, além do processo da descoberta da sexualidade, já abordado, destacam-se a rebeldia (práticas de contestação que podem ir do mero debate de ideias à prática de atos transgressores da moralidade e também da lei), a busca de identidade (que, comumente, leva à busca de identificação com um grupo), e a ânsia por novidades, que pode se traduzir em comportamento de risco, (impulsividade), comportamento este ligado, por sua vez, a uma suposta sensação de onipotência/invulnerabilidade (ligada, por sua vez, ao narcisismo) e incapacidade de avaliar o risco. Estes conceitos costumam ser utilizados, por exemplo, para explicar a prática de infrações da lei (civil ou penal) por adolescentes, prática esta que pode se dar tanto individualmente quando em grupo. A falta de limites também costuma ser agregada a esta explicação dos atos de delinquência juvenil.

Cumpre, portanto, explorar brevemente estas características nesta parte final do capítulo, já que terão importância na discussão a respeito dos riscos de violência sexual apresentados pela TIC e na formulação de diretrizes mínimas para políticas/programas/projetos/ações de prevenção. 
O comportamento de risco: Segundo HOUZEL, a razão da busca de novidades e do comportamento de risco comumente presentes na adolescência esta na "remodelagem do sistema de recompensa do cérebro, o conjunto de estruturas que nos premiam com uma sensação de prazer e nos fazem querer mais tudo aquilo que é bom ou dá certo". No início da adolescência, uma perda transitória de função deste sistema, causada por uma mudança neuronal ${ }^{460}$, leva às comuns sensações de tédio relatadas como características da adolescência. $\mathrm{O}$ adolescente passa a buscar novos prazeres, já que as antigas atividades infantis não the proporcionam mais a satisfação. O sistema de recompensa passa por um momento de 'embotamento', segundo a autora, e o adolescente passa a buscar novos prazeres. Talvez por isso, explica a autora, "o gosto por riscos seja norma na adolescência, e há quem julgue que riscos modestos constituam 'experimentação apropriada para a idade'. A evidência disso é que adolescentes que se engajam em riscos modestos são mais competentes socialmente (...) na idade adulta, do que aqueles que correm riscos demais ou nenhum" ${ }^{461}$.

Ainda segundo a autora, "o córtex pré-frontal dorsolateral, por exemplo, responsável pelo controle de impulsos, só atinge dimensões adultas após os 20 anos".

Assim, explica HOUZEL, “atos impulsivos, irresponsáveis e por vezes delituosos podem até ser 'instrumentos de provocação' - no entanto, na maioria das vezes nada mais são do que a decisão intempestiva de um cérebro que precisa de fortes estímulos para satisfazer um sistema de recompensa embotado, mas ainda sofre de imaturidade do córtex pré-frontal, por enquanto incapaz de controlar impulsos e de antecipar sozinho resultados indesejados que sirvam de freio ao comportamento" 462

Note-se, todavia, que o fato de adolescentes terem menor controle dos impulsos não significa que adolescentes não sejam capazes de controlá-los ou de ponderar riscos e vantagens e, com base nisso, tomar decisões. Porém, ao tomar decisões, "adolescentes costumam levar em conta mais os benefícios do que os riscos. Depois de pesar com

\footnotetext{
${ }^{460}$ Trata-se da redução dos receptores dopaminérgicos, essenciais à ativação do sistema de recompensas e, portanto, à sensação de prazer. É esta mesma mudança no sistema de recompensas torna o adolescente mais vulnerável à aquisição de vícios como o cigarro, o álcool ou as drogas ilícitas. Estas drogas levam a mudanças neuronais ainda mais intensas (redução ainda maior de receptores dopaminérgicos), de modo que se torna necessário consumir cada vez mais droga para sentir a sensação de prazer. Por isso, é muito mais difícil parar de fumar quando se inicia o hábito na adolescência.

${ }^{461}$ HOUZEL, op. cit., p. 34.

${ }^{462}$ Idem, p. 35.
} 
cautela os prós e os contras de uma situação, o cérebro adolescente tende com muita frequência a ficar do lado dos benefícios... e a escolher uma ação arriscada" ${ }^{463}$.

Ocorre que o adulto, ao ponderar esses fatores, coloca na balança situações que o adolescente, por não ter maturidade, ainda não é capaz de avaliar. A experiência faz com que a decisão adulta leve em conta não somente fatores racionais, mas outros riscos não triviais, além de contar com a intuição ${ }^{464}$.

$O$ narcisismo é também apontado como uma característica que está ligada à experiência de passagem da vida infantil para a adolescência. Para a psicanálise, na infância prevalece um 'narcisismo primário', ligado à já mencionada sensação de que a criança é 'tudo' na vida de seus pais. Ao longo da infância, a criança passa a perceber que a mãe não lhe pertence, que ele tem um rival (o pai) e, um pouco mais adiante, sabe que há outras pessoas, além dela (criança) que são importantes para seus pais. Todo esse processo vai levando a um "estilhaçamento" da sensação de ser amado com plenitude.

$\mathrm{Na}$ adolescência, é hora de "relativizar as exigências do narcisismo primário (querer ser tudo para alguém e para si mesmo, o que é impossível), restaurá-lo como narcisismo secundário (querer ser alguma coisa, o que é viável) ${ }^{465}$ ".

O narcisismo secundário se traduzirá, então, na adolescência, no desejo de ser alguém significativo, de criar, e ao mesmo tempo de sentir-se reconhecido e admirado por alguém, na busca de restaurar parte das experiências de amor vivenciadas na infância. "É preciso criar um estado de êxtase e de empolgação em alguém, transitar em duas vias, sendo objeto e sujeito de mais paixão" ${ }^{" 466}$.

A busca por esse lugar e por esse reconhecimento não se dão, portanto, somente na esfera da sexualidade, mas também na esfera da sociabilidade e no âmbito de instituições como a família e a escola. Pode haver intensos embates psíquicos internos no adolescente, que envolverão múltiplas exigências: as apresentadas pelos colegas, pela mídia (ser

\footnotetext{
${ }^{463}$ REYNA, Valerie F.; FALEY, Frank. Flerte com o perigo. In Revista Viver Mente \& Cérebro, O Olhar Adolescente, Tempo de Paixões. vol. 2.; São Paulo: Duetto. p. 65.

${ }^{464}$ REYNA, FALEY. Op cit. p. 69.

${ }^{465}$ CINTRA, Elisa Maria de Ulhôa. O despertar da sexualidade. In Revista Viver Mente \& Cérebro, O Olhar Adolescente, Vol. 1 - corpos em transição, p.36-45.

${ }^{466}$ CINTRA, op cit., p. 44.
} 
bonito, independente, popular), as exigências auto-impingidas, as expectativas de pais e mães, os próprios desejos; junte-se a isso um sentimento de inadequação, comparações com os amigos, frustrações, um SuperEgo muito repressor, e o resultado pode ser um adolescente cheio de conflitos.

Buscar a identificação com um grupo pode ajudar na passagem por este momento, que também se caracteriza por um gradual afastamento das figuras parentais e dos educadores. Esse movimento demanda que "o adolescente encontre na sociedade outros modelos e valores sólidos nos quais possa se apoiar até a consolidação da identidade" ${ }^{467}$.

Na busca do seu novo papel no mundo, é necessário experimentar, e nas interações em grupo surge a oportunidade desse ensaio. Em busca de sua individualidade e autonomia, os adolescentes encontram no grupo o locus para expressar seus sentimentos e visões de mundo sem precisar negociá-las (como teriam que fazer junto aos adultos), já que, desde que não sejam violadas as normas internas do grupo (que são, por sua vez, bastante flexíveis), seus pares costumam ser mais tolerantes que as instituições tradicionais (família, escola), que muitas vezes rejeitam valores e visões de mundo diferentes ${ }^{468}$.

OLIVEIRA utiliza o conceito de "tribos urbanas" de MAFFESOLI para apresentar a relação sujeito-grupo na adolescência contemporânea. $O$ sociólogo define as tribos urbanas como "agrupamentos semi-estruturados, com estrutura normativa frouxa, marcada pela lógica hedonista do prazer momentâneo e não compromissado: apenas o aqui e o agora são valorizados" ${ }^{469}$. São organizados em torno de gostos e formas de lazer, com vínculos frouxos que perduram enquanto se mantém o interesse comum. No contexto desses grupos, os adolescentes interpretam papéis, apresentando sua subjetividade de forma parcial, conforme cada situação requer.

Três são os 'eixos imaginários' que estruturam esses grupos: a conduta e imagem visual (roupa, corte de cabelo, cores, acessórios); demarcação de território (ocupação de determinados recortes do espaço urbano); comportamento social de risco (não é regra em

\footnotetext{
${ }^{467}$ OLIVEIRA, Maria Claudia Santos Lopes. Vínculos imaginários. In O Olhar Adolescente: tempo de paixões. vol. 2, p20-29. Duetto Editorial. p. 21.

468 OLIVEIRA, op. cit., p. 22

${ }^{469}$ Idem, ibidem, p. 28.
} 
todos os grupos, embora seja característica de alguns, motivados pela sedução do desafio e do desconhecido $)^{470}$.

A participação no grupo leva a uma sensação de pertencimento, conferindo aos seus membros uma identidade que OLIVEIRA qualifica como ilusória, já que não há tensões ou diferenciações dentro dos grupos (somente entre grupos, o que permite diferenciar seus membros dos demais). Ironicamente, apesar de a busca do grupo se dar no âmbito de um processo de busca construção da identidade, a participação dentro desses específicos grupos, a partir desta interpretação teórica, não contribui para a diferenciação, da qual depende a formação das identidades singulares ${ }^{471}$.

Se esta conclusão a respeito das tribos urbanas for verdadeira, parece que elas pouco estimulam os processos de participação que, do mesmo modo que são importantes na infância, o serão na adolescência, para o desenvolvimento cognitivo, moral, social. O desafio, o estímulo à curiosidade, se podem ser feitos pelas autoridades (pais, escola), podem e deve ser enfrentados de modo individual, mas ganham mais riqueza se enfrentados e compartilhados também entre pares. A cooperação, como já salientado anteriormente, é essencial porque as relações de coação pouco fazem para estimular o processo de amadurecimento psicológico. Não é preciso esforço intelectual para obedecer, não é preciso refletir a respeito. E por isso mesmo, não conduzem à autonomia: o sujeito se contenta em ser aprovado ou reprovado, e, como não tomou decisões, por elas também não se torna responsável ${ }^{472}$.

Para o desenvolvimento da autonomia, é necessária a relação de cooperação. É preciso exercitar a argumentação, pensar, analisar os argumentos alheios, entender diferentes pontos de vista. E a capacidade de assumir responsabilidades - que faz parte da autonomia - acompanha a cooperação, já que as decisões são tomadas em conjunto.

A descoberta da própria identidade, e o desenvolvimento do autorrespeito fazem parte desse processo e serão essenciais para a obtenção da autonomia futura.

\footnotetext{
${ }^{470}$ Esta descrição lembra, novamente, a história de Patrícia, que parece ter passado por mais de uma "tribo urbana" durante o seu processo de transformação.

${ }^{471}$ Idem, ibidem, p. 29.

${ }^{472}$ LA TAILLE, Yves de. Formação ética..., p. 150.
} 
As figuras parentais têm papel determinante no desenvolvimento adolescente, participando de um jogo delicado em que é preciso decidir, a cada dia, o quanto se pode ceder e qual o "limite para o limite". Para além do natural conflito de gerações que provocará as contestações e transgressões, entram em cena outras questões não tão claras, como as fantasias e sonhos idealizados pelos pais para seus filhos, a projeção de suas angústias e medos, e a tentativa de imposição de valores morais que nem sempre estão em sintonia com os "novos tempos" em que vive o adolescente.

Esses "novos tempos" são "tempos confusos", mesmo (talvez, principalmente) para os pais e avós desses adolescentes, que vivenciam as já mencionadas mudanças econômicas, sociais e culturais que se refletem no cotidiano do mercado de trabalho, da família e da escola. E se, dos adultos, sempre se esperou orientação e supervisão no processo de desenvolvimento infantojuvenil, os "novos tempos" exigem preparo extra para orientar crianças e adolescentes com relação a instrumentos e tecnologias que poucos adultos dominam, como as TIC.

Neste ponto, questiona-se até que ponto a questão do (i)letramento digital dos pais é determinante ou relevante. Conforme se viu anteriormente, crianças e adolescentes relatam a falta de confiabilidade em seus pais quando acontecem situações de conflito ou insegurança; relatam, ainda, que as respostas, muitas vezes, são repressoras (proibição do uso da internet ou punição). Sabe-se também que, quando se trata de queixas ligadas à sexualidade, as reações de familiares tendem a ser díspares, mas há extensa literatura sobre violência sexual que aponta a frequente reação de descrença diante de relatos de $\operatorname{abusos}^{473}$; assim como a minimização do bullying (e do cyberbullying) e de seus efeitos negativos pode ser, muitas vezes, decorrente de ignorância a respeito.

Seria suficiente o letramento digital para instrumentalizar esses pais para guiar os seus filhos nos meandros do mundo virtual? A resposta parece ser negativa, embora o conhecimento seja, sim, componente importante. Pode ser difícil orientar uma criança ou um adolescente no uso de um equipamento que não se conhece, e a falta dessa orientação pode ser interpretada pela criança como sinal de fraqueza dos pais, educadores ou

\footnotetext{
${ }^{473}$ Mormente quando o abuso sexual é praticado por familiar (abuso sexual intrafamiliar). As razões para esta descrença ou descaso são inúmeras, sendo algumas delas o receio de desestruturação da família e os já mencionados preconceitos a respeito palavra das crianças (mentirosas, imaginativas etc).
} 
responsáveis. Conforme aponta ARATANGY, o fato de, em uma família, as crianças dominarem a linguagem das tecnologias de informação pode fazer com que adquiram poder desproporcional à sua competência, o que é evidentemente prejudicial a todos os envolvidos.

Além disso, a ignorância a respeito das "novidades" que os jovens trazem para dentro de casa sempre gerou conflitos entre pais e filhos. A expressão "no meu tempo tudo era diferente" vem sendo repetida por gerações e gerações de pais, que outrora foram filhos (e ouviram exatamente o mesmo de seus pais). Este parece, portanto, ser mais um componente dentro de um conflito de gerações que se expressa em uma série de outras instâncias familiares. Não seria diferente com relação à tecnologia.

Porém, prossegue a psicanalista, "a autoridade dos pais não se baseia na posse de informações acumuladas, e sim na responsabilidade de criar e proteger os filhos (...). As informações são úteis para o exercício da tarefa, mas não basta ser bem informado para criar bem os filhos. A experiência e a sensibilidade, guiadas pelo afeto, são os instrumentos mais importantes desse processo" ${ }^{474}$.

Não basta proibir ou permitir, portanto. Para além de guiar os filhos no uso da tecnologia, a participação parental no processo de desenvolvimento precisa contemplar os questionamentos naturais desta fase, guiando os filhos no processo de descoberta de si mesmo e das respostas às perguntas éticas e morais que naturalmente surgem: que vida quero viver? O que é viver uma vida significativa ${ }^{975}$ Como quero viver com os outros? Em que mundo quero viver?

${ }^{474}$ ARATANGY, op. cit, p. 20.

${ }^{475}$ LA TAILLE, op. cit., p 154-155. 


\section{PARTE III - Vitimologia, Ciências Criminais Integradas e prevenção vitimal da violência sexual contra crianças e adolescentes mediada pela TIC}

Até o momento, apresentaram-se elementos interdisciplinares considerados relevantes para a elaboração de estratégias de prevenção vitimal da violência sexual contra crianças e adolescentes mediada pela TIC.

Buscou-se apresentar um panorama amplo da sociedade em rede onde essas crianças e adolescentes estão inseridos, as novas formas de sociabilidade e as transformações sociais que acompanham a revolução tecnológica e econômica pela qual passa o mundo hoje; e situar as vivências de crianças e adolescentes brasileiras na sociedade em rede, refletindo sobre suas realidades, sobre o uso que fazem da TIC no seu cotidiano e as condições desse uso.

A violência sexual contra crianças e adolescentes em sentido amplo e em suas acepções específicas foi caracterizada a partir de aportes teóricos interdisciplinares, e de modo mais específico, identificou-se o que é, como se dá e quais os impactos que a violência sexual mediada pela TIC pode ter sobre crianças e adolescentes, tanto a partir da legislação, quanto utilizando dados de pesquisas de vitimização e de revisão de literatura a respeito da questão. Também foram discutidas as concepções a respeito dos atores envolvidos na (com a) violência sexual contra crianças e adolescentes.

O estudo dos direitos à participação e ao desenvolvimento (Capítulos 3 e 4) foi enfatizado com o intuito de servir como ponto de partida para o pensar da prevenção a partir do que é ser criança e do que é ser adolescente; buscou-se caracterizar esses sujeitos como atores capazes de compreender o mundo à sua volta e de, conforme a idade e o estágio de seu desenvolvimento, participar ativamente da construção de sua realidade.

Também o estudo da participação e do desenvolvimento também busca dar mais subsídios para a compreensão de quem são os demais atores presentes na vida da criança/adolescente, e qual a importância desses atores (em especial sua família e seu pares) nos processo de desenvolvimento. Também se espera que tenha ficado clara a compreensão do quão complexo é o processo de desenvolvimento, o que indica que 
impactos significativos neste processo podem ter repercussões de vários níveis, atuais e futuras, na vida de crianças e adolescentes.

Assim, apesar de as reflexões sobre Vitimologia e a apresentação de um modelo possível para a prevenção vitimal serem apresentadas ao final, o foco na vítima, objeto de estudo da Vitimologia foi o guia dos demais elementos interdisciplinares até o momento apresentados. A partir das crianças e adolescentes, de suas vivências e de suas vozes, agregadas à experiência e saberes teórico-práticos de adultos, é possível pensar elementos de prevenção vitimal que tenham significado e que possam impactar positivamente em suas vidas.

Além disso, por ser um estudo interdisciplinar, era necessário identificar os elementos que pudessem ser integrados à perspectiva vitimológica adotada, que vem aqui apoiada nos Direitos Humanos, nos Direitos de Crianças e Adolescentes e em uma Criminologia que busca um diálogo entre os paradigmas do fato social bruto e da reação social, integrando perspectivas que, até o momento, eram vistas como antagônicas.

Assim, ao invés de alinhada com uma Vitimologia "punitiva", que coloca a vítima como sujeito passivo e cobra medidas de proteção para vítimas em detrimento dos direitos dos "delinquentes" ("Direitos Humanos para Humanos Direitos"), busca-se uma aproximação de prevenção vitimal que enxergue todos os participantes como sujeitos participantes do conflito.

Adiante, também se apresenta o modelo ecológico de desenvolvimento, tradicionalmente utilizado em intervenções nas áreas de saúde e social, em uma abordagem (modelo da ecologia social dos direitos da criança e do adolescente) que coloca crianças e adolescentes no centro e parte de suas realidades vividas para o pensar de estratégias de prevenção. Por fim, problematiza-se o modelo inserindo-se a discussão do medo do crime, presente no meio social e propagandeado pela mídia, que se encontra também presente nos movimentos de direitos de crianças e adolescentes, e que deve ser tematizado ao se pensar em estratégias de prevenção. 


\section{Capítulo 5 -Vitimologia, Criminologia, Política Criminal e Direitos Humanos: prevenção vitimal centrada na criança e no adolescente}

\subsection{A Vitimologia e a vítima criança/adolescente}

A análise da escassa literatura de vitimologia disponível no Brasil aponta algumas questões que precisam ser analisadas ao se pensar em medidas de prevenção de violência sexual facilitada pela TIC.

A primeira destas questões é a concepção a respeito da vítima criança/adolescente. Refletindo uma ideologia concepção positivista, as concepções vitimológicas sobre as crianças vinham, até pouco tempo, carregadas de preconceitos e de senso comum. Enquanto o "criminoso nato" (categoria da Criminologia de cunho biológico em que facilmente se pode enquadrar, hoje, segundo o senso comum, o "pedófilo", como visto no Capítulo 2) era visto como alguém irrecuperável, a vítima é vista como indefesa e incapaz.

Na visão positivista do início do século $X X$, as crianças merecem o mesmo tipo de avaliação que as mulheres, sendo que estas são consideradas inferiores, ardilosas, sugestionáveis, fracas: “A mentira, geral na humanidade, atinge na mulher, como na criança, um máximo de intensidade. Nela, a mentira é fisiológica e estimulada por uma infinidade de causas $(. . .)^{476} \%$. Este é um trecho da obra La Donna Delinquente, de Lombroso e Ferrero, publicada em 1917, mas expressa uma visão que, até recentemente, se verificava em obras e artigos tratamento do testemunho infantil, inclusive (e, talvez, principalmente) nos casos de violência sexual.

Em diversas obras examinadas expressam-se ideias contraditórias a respeito das crianças vítimas. Consideradas inocentes, vulneráveis e indefesas, poderíamos, então, acreditar que, por esta razão, mereceriam mais proteção. Ironicamente, o outro lado desta moeda é a frequente consideração de que o testemunho das crianças não merece valor por serem esses sujeitos extremamente suscetíveis a mentiras e influenciáveis (o que, paradoxalmente, acaba por levá-las a uma situação de desproteção).

\footnotetext{
${ }^{476}$ DARMON, Pierre. Médicos e assassinos na Belle Époque. Trad. Regina Grisse de Agostino. São Paulo: Paz e Terra, 1991, p. 63 apud SHECAIRA, Sérgio Salomão. Criminologia. São Paulo: Editora Revista dos Tribunais, 2009; p. 111.
} 
A equiparação entre crianças, loucos e mulheres também perdurou até muito recentemente nas escassas obras de vitimologia publicadas no Brasil:

\begin{abstract}
"Quanto à palavra da vítima infantil (...) os problemas de fantasias, traumas, e recalques emocionais, sugestionabilidade, imaginação, alcançam patamares incomuns, raramente atingidos na vítima mulher adulta, salvo em casos extremos de histeria ou neurose histérica. É extremamente volátil o depoimento infantil em tema de crimes sexuais, porque as pequenas vítimas, quasevítimas ou pretensas vítimas tendem a fantasiar, jogam excessivamente com a imaginação, são altamente sugestionáveis e tornam-se extremamente susceptíveis à influência de médicos, psicólogos e psiquiatras [principalmente se esses profissionais forem do sexo feminino]; trabalham desordenadamente com parâmetros de tempo e lugar (...)."477
\end{abstract}

"A idade da vítima é outro fator a ser levado em consideração, sobretudo quando se trata de depoimentos de crianças, que só podem ser recebidos com extremas cautelas" ${ }^{\prime 478}$.

“(...) Particularmente, na questão, o que se deve atender é a grande possibilidade de acusações falsas por diversos motivos (fantasia, imaginação fértil, vingança, chantagem ou extorsão) por supostas vítimas - principalmente em se tratando de crianças e mulheres histéricas" ${ }^{\$ 79}$.

E até hoje, as visões de muitos doutrinadores e operadores do direito ainda refletem estas mesmas concepções:

${ }^{477}$ GUILHERME DE SOUZA, José. Vitimologia e Violência nos Crimes Sexuais. Sergio A. Fabris Editor, 1998. p.121

${ }^{478}$ BITTENCOURT, Edgard de Moura. Vítima. $3^{\circ}$ Edição. São Paulo: Universitária de Direito, 1987, p. $146 \mathrm{O}$ autor segue comparando a criança aos "debéis mentais", que devem, igualmente, ter suas declarações como sujeitos passivos do crime apreciadas com cautela.

${ }^{479}$ ALVES, Roque de Brito. A vítima de crime sexual. In KOSOVSKI, Ester. Vitimologia. Enfoque Interdisciplinar. Socied. Bras. de Vitimologia, 1993, p. 368 
"Quando se afirma que não se deferirá o compromisso aos doentes mentais ou aos menores de 14 anos, não é porque eles estejam desobrigados de dizer a verdade, mas porque eles não têm maturidade e discernimento, quando não a capacidade mental, para compreenderem o significado de uma promessa, sob palavra de honra, de dizer a verdade" ${ }^{480}$. [itálicos no original]

TOURINHO FILHO ${ }^{481}$, conhecido processualista brasileiro, inicia um tópico sobre o testemunho infantil do seguinte modo:

\begin{abstract}
"doutrina Bernard Perez: quando ela [criança] tem grande interesse em mentir, procede com arte... se o seu papel de comediante não é longo, consegue tornar-se acreditada" (...). E Le Bon, por sua vez, proclamava que escutar a voz de uma criança equivale a proferir a condenação do acusado por cara ou coroa..."
\end{abstract}

Logo após, busca matizar esses dizeres, asseverando que:
"o certo é que o depoimento de uma criança não pode ter total desvalia (...) Não se pode exigir de uma criança a maturidade de um adulto. Pode inventar, pode criar, pode querer transformar- se no centro das atenções, pode fantasiar. Se mentir, não o faz por perversidade, por maldade (...)" [destaquei]

Cita, em seguida um julgado: "Inúmeros julgados têm lembrado o perigo consistente em condenar alguém com base unicamente em depoimento infantil, pela insinceridade de que por vezes é cercado, pela sugestionabilidade e confusões oriundas de fantasias, ou mesmo como reprodução de fatos pretéritos e que ficam gravados na memória do infante (RT 604/333)”. [destaquei]

\footnotetext{
${ }^{480}$ PACELLI, Eugenio, Curso de Processo Penal. 16 edição São Paulo: Atlas, 2012, p. 410.

${ }^{481}$ TOURINHO FILHO, Fernando da Costa. Processo Penal. 32 edição. São Paulo: Saraiva, 2010; p. 337 338
} 
O tópico sobre testemunho infantil é fechado com "chave de ouro" com a seguinte observação a respeito do testemunho feminino: "A respeito do testemunho da mulher, conforme ensina Ayarragaray, pode ser perturbado por sua sensibilidade especial ou por disposições psicofisiológicas próprias de seu ser, aliadas à circunstância de serem as mulheres relativamente sugestionáveis". [destaquei]

Os autores acima citados são conhecidos do público universitário e seus manuais amplamente utilizados em cursos jurídicos. Mais de 50 anos após a "revolução feminina", mais de 20 anos depois da CIDC e da CF 88, mulheres, loucos e crianças continuam sendo equiparados e considerados indignos de crédito pelos respeitados doutrinadores brasileiros.

As concepções acima claramente dialogam com a visão tutelar da Doutrina da Situação Irregular do Direito do Menor, que perdurou desde a criação dos primeiros Tribunais de Menores (nos EUA, em 1899) e que no Brasil se institucionaliza com o Código Mello Mattos, de 1927, e se consagra definitivamente em 1979, com o Código de Menores. Do mesmo modo, se identificam com a já mencionada invisibilidade de crianças e adolescentes e com os estereótipos a elas associados, discutidos nos Capítulos 3 e 4.

Em levantamento de literatura de juristas a respeito do testemunho das crianças, realizado no escopo de um estudo sobre os significados do envolvimento das crianças em procedimentos judiciais nos casos de abuso sexual, RIBEIRO e MANITA chamam atenção para o fato de que, "frequentemente, o sistema jurídico classifica as crianças como testemunhas incompetentes (...) ou pouco credíveis devido ao facto de seu relato factual parecer contraditório, inconsistente ou confuso. (...) Os estudos realizados incidem preferencialmente nas capacidades mnésicas, na sugestionabilidade, na capacidade de discernimento, na veracidade, na credibilidade dos testemunhos da criança e nos obstáculos ou potenciais dificuldades na interpretação do testemunho da criança" ${ }^{482}$.

\footnotetext{
${ }^{482}$ RIBEIRO, Catarina; MANITA, Celina. Crianças vítimas de abuso sexual intra-familiar: significados do envolvimento no processo judicial e do papel dos magistrados. Revista do Ministério Público, Lisboa, v. 28, n. 110, p.47-86, jun. 2007. p. 58-59. É bom salientar que a concepção a respeito da credibilidade da palavra da criança não é uma exclusividade do Sistema de Justiça ou de uma específica Vitimologia. Como já salientado no estudo do direito à participação (cf. Capítulo 3), a concepção da criança como incapaz de entender o mundo e/ou de se expressar, manifestar sua vontade, fazer escolhas, está presente no senso comum.
} 
Não é em toda a situação que o depoimento da criança representa um problema, todavia. Segundo as autoras, em situação de negligência e maus-tratos, o testemunho da criança não parece posto em causa. "A questão da credibilidade do relato curiosamente apenas se coloca para a criminalidade sexual. (...) Paradoxalmente, os casos de abuso sexual parecem ser os que mais suscitam a participação da criança no cenário judicial".

As autoras prosseguem indicando que é central, no debate a respeito do testemunho infantil a capacidade de distinguir verdade e mentira, que seria fundamental para apurar a verdade dos fatos - mormente nos casos de abuso sexual, em que, muitas vezes, o depoimento da vítima não pode ser corroborado por depoimentos de outras testemunhas e, dependendo do tipo de abuso sofrido ou mesmo do tempo decorrido entre o abuso e a sua revelação, pode ser que não haja provas materiais como lesões corporais ${ }^{483}$.

Advertem, porém, que a questão da "verdade" pode ser até mesmo classificada como uma falsa questão, já que mesmo tendo capacidade de discernimento, adultos frequentemente mentem em tribunais ${ }^{484}$.

Não é possível dizer que crianças tenham mais tendência a mentir que adultos. Aliás, "os dados das investigações científicas têm vindo a demonstrar que as crianças revelam elevadas competências testemunhais e comunicacionais, bem como uma capacidade de discernimento superior à que frequentemente lhes é atribuída. No entanto, as capacidades de retenção de informação, de organização do pensamento e de produção narrativa são mais limitadas nas crianças de idade pré-escolar, comparativamente com as competências apresentadas por crianças das faixas etárias seguintes" ${ }^{\text {485. }}$.

Esta última passagem faz o alerta para a necessária diferenciação entre esta concepção preconceituosa a respeito das crianças e adolescentes e de sua capacidade de

\footnotetext{
${ }^{483}$ A respeito, cf COHEN, Claudio; GOBBETTI, Gisele J. Abuso sexual infrafamiliar. Revista Brasileira de Ciências Criminais, São Paulo, v. 6, n. 24, p.235-243, out./dez. 1998. Segundo os autores, "a maioria destas relações [de abuso sexual intrafamiliar incestuosas], quando denunciadas, dificilmente obterão provas objetivas da ocorrência através de um exame de corpo de delito (...). A maioria destes relacionamentos são efetivados através de carícias e toques, não culminando em uma relação sexual completa, sendo que isto não diminui necessariamente a gravidade das consequências a seus participantes, pois não é a agressão física que define o abuso e sim a violência emocional que pode estar por trás do fato". p. 240

${ }^{484}$ A psicologia do testemunho, aliás, já identificou o quanto a percepção e a memória, mesmo de adultos, podem ser falhas e incompletas, havendo, ainda, uma série de mecanismos psíquicos inconscientes que podem resultar em testemunhos que não correspondem ao que a pessoa vivenciou, por conta de distorções nos processos de fixação, conservação e até mesmo no momento de evocação da memória.

${ }^{485}$ RIBEIRO,; MANITA. op cit, p. 59-60.
} 
testemunhar, e a consideração de uma série de fatores concretos que têm relevância, por exemplo, no exame do testemunho infantil, fatores estes ligados ou não à especificidade das relações de abuso sexual, em especial quando acontecem em âmbito intrafamiliar.

Alguns desses aspectos são apontados por COHEN e GOBBETTI, como a dificuldade em "discriminar o que é abusivo e o sentimento de culpa provocado pela participação, muitas vezes consentida, destas crianças e adolescentes na relação incestuosa", fatores que podem influenciar na omissão ou imprecisão dos dados, entre outros.

Não se pretende, portanto, negar que haja, sim, especificidades com relação à vítima criança/adolescente que devam ser consideradas, seja no estabelecimento de medidas de prevenção (como é o caso da presente pesquisa), seja quanto ao seu depoimento e à valoração que a ele se dá, seja com relação à medidas de proteção.

Ao contrário, e esta é uma das razões pelas quais se discute, neste trabalho a participação e o desenvolvimento de crianças e adolescentes, é preciso, exatamente, levar em consideração a complexidade desses sujeitos em suas diferentes etapas de desenvolvimento, para escapar do senso comum que continua considerando crianças (e, como se viu acima, ainda que de modo velado, e por vezes abertamente, mulheres, e loucos), como sujeitos completamente indefesos, vítimas incapazes de se defender e, sendo efetivamente vitimizadas, incapazes também de dar um testemunho confiável.

Diante disso, é preciso, neste ponto, estabelecer os princípios da Vitimologia e da Política Criminal a partir dos quais serão organizados os elementos de prevenção vitimal até o momento apresentados.

\subsection{Vitimologia, Criminologia, Política Criminal e Direitos Humanos: paradigmas para a prevenção vitimal.}

A perspectiva vitimológica que ilumina o presente trabalho é, em primeiro lugar, uma perspectiva intrinsecamente relacionada com a Criminologia. Não faz parte do escopo do presente trabalho discutir a autonomia ou não da Vitimologia com relação à 
Criminologia; parte-se do pressuposto de que não há Vitimologia sem Criminologia, e vice-versa ${ }^{486}$.

Neste sentido, ao comentar a questão da autonomia da Vitimologia como ciência autônoma, CÂMARA afirma que "existe uma imbricação e uma complementaridade inarredável entre criminologia e vitimologia e ainda que possuam pronunciados aspectos particulares e específicos, não podem ser compreendidas nem estudadas de modo unilateral: são mutuamente dependentes, mas o objeto da criminologia, por ser mais amplo, abrange o da vitimologia" ${ }^{487}$.

Parte-se, portanto, de uma Vitimologia que tem como objeto as vítimas de crimes. Poderia se objetar que o foco do presente trabalho são vítimas potenciais (também chamadas de virtuais), e que portanto, não são, ainda, vítimas de crimes. Argumento, com OLIVEIRA, que a "vitimologia não trata, afinal, de uma vítima específica de um crime específico, [de modo que] restringir seu objeto à vítima de crime não significa excluir a análise das vítimas potenciais, nos estudos preventivos (...)"488.

Esta Vitimologia tampouco se divorcia da Política Criminal e da Dogmática Jurídica. Como salienta CÂMARA, aliás, a prevenção voltada para vítimas virtuais (potenciais), pertence mais ao campo da Política Criminal do que ao campo do Direito Penal, não sendo possível, porém, divorciarem-se as perspectivas.

Se antes a finalidade da Política Criminal era controlar a criminalidade, "com o desenvolvimento da vitimologia e, em particular, através da preocupação com as necessidades da vítima, do seu ambiente social e da sociedade, o campo de ação da

\footnotetext{
${ }^{486}$ Não se desconhece a discussão a respeito relação dos "crimes sem vítima" ou sobre a amplitude da Vitimologia, que poderia abordar o estudo de vítimas de desastres, dos problemas sociais e econômicos, etc ("vítimas sem crime"). A respeito, cf. OLIVEIRA, Ana Sofia Schmidt de. A Vítima e o Direito Penal. São Paulo: RT, 1999, p76-87; CÂMARA, Guilherme Costa. Programa de política criminal: orientado para a vítima de crime. São Paulo: Revista dos Tribunais / Coimbra Ed., 2008. 393 p. 63-80; PIEDADE JR, Heitor. Vitimologia. São Paulo: Freitas Bastos, 1993; p.119-130; BITTENCOURT, Edgard de MOURA. Vítima. $3^{\circ}$ Edição. São Paulo: Universitária de Direito, 1987; p 41-51.

${ }^{487}$ CÂMARA, op cit, p. 73-74.

${ }^{488}$ OLIVEIRA, op. cit., p. 86.
} 
política criminal se estende (...) também ao controle das consequências do crime ${ }^{489 "}$ e da sua prevenção.

Com isso quer se dizer que, se não cabe tanto ao Direito Penal orientar-se exacerbadamente para a proteção das vítimas (o que ocorre, com frequência, no Brasil, resultando em recrudescimento de penas e em novas criminalizações), cabe à Política Criminal, orientada por um olhar vitimológico, desempenhar este papel, sem perder de vista, contudo, os direitos dos demais protagonistas da dinâmica do desvio (autores de crime/acusados etc), sob o risco de nos direcionarmos a uma Política Criminal reacionária ${ }^{490}$.

Incumbe à Vitimologia, no contexto de uma Criminologia dinâmica, empírica, extensiva e interdisciplinar, portanto, "cobrir espaços teórico-empíricos implicados com a descrição delinquente ${ }^{491}$-vítima e suas cambiantes projeções, com o conjunto de atitudes e reações determinantes da vítima, sua vulnerabilidade, seleção, aumento dos riscos, bem como, com o fenômeno da vitimização difusa e indiscriminada, com especial ênfase na prevenção de todas as formas de vitimização criminal e na reparação dos danos. ${ }^{492 »}$

LARRAURI $^{493}$ identifica que a Vitimologia que se desenvolve a partir dos anos 1980, em especial nos EUA, apesar de adotar uma perspectiva de não contrapor os direitos da vítima aos do delinquente, surge a partir da necessidade de justificação de uma política de lei e ordem; da necessidade de estabelecer um contrapeso à criminologia crítica, em resposta ao ímpeto do movimento feminista e face ao surgimento e ao impacto das pesquisas de vitimização, que escancaravam as cifras negras de delito.

\footnotetext{
${ }^{489}$ BARATTA, Alessandro. Defesa dos direitos humanos e política criminal. Discursos Sediciosos: crime, direito e sociedade, Rio de Janeiro, v. 2, n. 3, p.57-69, 1997; p. 57.

${ }^{490}$ CÂMARA, op cit. p, 150.

${ }^{491}$ Considero que seria mais adequada a expressão "vitimário" ao invés de delinquente; apesar disso, como já dito anteriormente, qualquer forma de definição a partir do crime e do desvio, mesmo no caso da vítima, tem um componente em si estigmatizante, de modo que escapar de tais rotulações torna-se constante desafio quando é necessário formular definiçõos.

${ }^{492}$ CÂMARA, op cit, p. 75.

${ }^{493}$ LARRAURI PIJOAN, Elena. Victimología. In: MAIER, Julio B. J. De los delitos y de las víctimas. Buenos Aires: Ad-Hoc, 2001. 316 p. ISBN 950-9606-44-8. p.281-316.
} 
É claro, também, para ALVAREZ ${ }^{494}$, o desenvolvimento de uma "política criminal de matriz neoconservadora" que, no Brasil, se evidencia, por exemplo, na Lei dos Crimes Hediondos e no recrudescimento, em geral, da legislação penal. Contudo, analisando a política criminal brasileira com relação à inclusão da vítima no processo penal, ALVAREZ identifica dois outros movimentos: o primeiro, buscando "combater a despersonalização do conflito e os efeitos vitimizadores da abordagem clássica jurídicopunitiva", se refletiu na criação dos Juizados Especiais Criminais e na já mencionada justiça restaurativa (cf. Capítulo 3), embora, na avaliação do autor, a vítima não tenha exatamente sido alçada à condição de protagonista; o outro, ligado aos movimentos de mulheres e que culminou na promulgação da Lei Maria da Penha (Lei 11.340/2006) ${ }^{495}$ e que buscou reconfigurar o papel da vítima no sistema de justiça criminal brasileiro, embora, também neste caso, não tenham as vítimas atingido, na avaliação do autor, uma real posição de protagonismo ou tenham tido seus anseios atendidos.

Apesar das falhas na implementação das duas leis, contudo, para o autor fica claro o espaço, identificado nos discursos das vítimas e dos posicionamentos assumidos por atores do Sistema de Justiça Criminal entrevistados na pesquisa realizada, que têm sido abertas "perspectivas de maior protagonismo para as vítimas no âmbito da justiça criminal que não resvalem para a deriva do populismo penal, ou seja, da instrumentalização da vítima em prol de uma política criminal de matriz neoconservadora" ${ }^{496}$

Identificam-se similares movimentos na política criminal focada nas vítimas crianças e adolescentes.

É possível, observando os grupos de defesa de Direitos da Criança e do Adolescente, pois, identificar dois movimentos, na mesma linha do que ALVAREZ constata com relação à Vitimologia. Desde a constituição do Conselho Nacional de Direitos da Criança e do Adolescente (Conanda) em 1991, as políticas públicas relacionadas aos direitos de crianças e adolescentes no Brasil, têm sido traçadas por este órgão. Criado pela Lei Federal n ${ }^{\circ}$ 8.242, de 12 de outubro de 1991, o Conanda é um órgão

\footnotetext{
${ }^{494}$ ALVAREZ, Marcos César et al. A vítima no processo penal brasileiro: um novo protagonismo no cenário contemporâneo? Revista Brasileira de Ciências Criminais, São Paulo, v. 18, n. 86, p.247-288, set./out. 2010. ${ }^{495}$ A Lei Maria da Penha criou mecanismos, determinou a implementação de políticas de prevenção e de proteção às vítimas e aumentou penas para o crime de violência doméstica e familiar contra a mulher. ${ }^{496}$ ALVAREZ, op cit, p. 287.
} 
deliberativo nacional federal, encarregado da formulação, monitoramento e avaliação das políticas de promoção, proteção e defesa dos direitos da criança e do adolescente no Brasil $^{497}$.

As decisões do Conanda têm força vinculante, ou seja, a diretriz para a política pública em nível nacional, que depois se irradiará para Estados e Municípios, é dada pelo Conselho. O processo de elaboração da política, que até 2010 vinha sendo consubstanciada em planos temáticos, e que, recentemente, se estruturou em um Plano Decenal global, se dá com intensa participação da sociedade civil e governo em todos os níveis, de modo ascendente ${ }^{498}$.

${ }^{497}$ Conforme o $\operatorname{artigo} 2^{\circ}$ da Lei, compete ao Conanda I. elaborar as normas gerais da política nacional de atendimento dos direitos da criança e do adolescente, fiscalizando as ações de execução, observadas as linhas de ação e as diretrizes estabelecidas nos arts. 87 e 88 da Lei no 8.069, de 13 de julho de 1990 Estatuto da Criança e do Adolescente;

II. Zelar pela aplicação da política nacional de atendimento dos direitos da criança e do adolescente;

III. dar apoio aos Conselhos Estaduais e Municipais dos Direitos da Criança e do Adolescente, aos órgãos estaduais, municipais, e entidades não-governamentais para tornar efetivos os princípios, as diretrizes e os direitos estabelecidos na Lei $n^{\circ} 8.069$, de 13 de julho de 1990;

IV. avaliar a política estadual e municipal e a atuação dos Conselhos Estaduais e Municipais da Criança e do Adolescente;

V. (vetado)

VI. (vetado)

VII. acompanhar o reordenamento institucional propondo, sempre que necessário, modificações nas estruturas públicas e privadas destinadas ao atendimento da criança e do adolescente;

VIII. apoiar a promoção de campanhas educativas sobre os direitos da criança e do adolescente, com a indicação das medidas a serem adotadas nos casos de atentados ou violação dos mesmos;

IX. acompanhar a elaboração e a execução da proposta orçamentária da União, indicando modificações necessárias à consecução da política formulada para a promoção dos direitos da criança e do adolescente;

$X$. gerir o fundo de que trata o art. $6^{\circ}$ da lei e fixar os critérios para sua utilização, nos termos do art. 260 da Lei ${ }^{\circ} 8.069$, de 13 de julho de 1990 ;

XI. elaborar o seu regimento interno, aprovando-o pelo prazo de, no mínimo, dois terços de seus membros, nele definindo a forma de indicação do seu Presidente.

${ }^{498}$ O processo de estruturação da Política Nacional começa com a definição, pelo Conanda, de diretrizes e eixos orientadores das conferências, que são realizadas a cada dois anos pelos Conselhos Municipais e Estaduais de Direitos da Criança e do Adolescente (CMDCAs e CONDECAs). Municípios maiores costumam, antes da Conferência Municipal, realizar, também, Conferências Regionais. Desde 1999, inicialmente na cidade de São Paulo, também são realizadas Conferências Lúdicas (específicas para crianças e adolescentes).

As discussões são realizadas em tornos das diretrizes e eixos propostos, e das Conferências Municipais saem, eleitos, delegados para as Conferências Estaduais e, das Estaduais, para a Conferência Nacional.

Este se caracteriza como um processo ascendente de elaboração de política pública, pois parte da realidade dos cidadãos que, norteados pelos eixos propostos, identificam os pontos que precisam de atenção e levam seus pleitos ao plenário em nível nacional.

A deliberação final sobre a política é realizada na Conferência Nacional. Esta decisão é vinculante, significando que os Governos Federal, Estaduais e Municipais devem executá-la fielmente, com a participação dos Conselhos em todo o processo, já que são responsáveis pela fiscalização de sua execução, entre outras funções. Vale lembrar que a composição dos Conselhos em níveis Estadual e Municipal também é paritária (embora, em muitos municípios, haja notícia de que a participação da sociedade civil é meramente formal). 
No que toca à execução da política, o processo se dá de forma descendente. A partir do sucesso ou não da implementação da política, nas três esferas de governo, novas diretrizes e eixos serão definidas para orientar as Conferências, cujos resultados serão determinantes para a reelaboração da política nacional. Assim, ao menos em teoria, o processo de elaboração e execução da política pública de Direitos da Criança e do Adolescente, no Brasil, se dá de forma ascendente e descendente, havendo permanente retroalimentação, configurando-se como um fluxo contínuo e circular.

Como expressões deste movimento, temos, com relação à questão da violência sexual contra crianças e adolescentes, a elaboração do como o Plano Nacional de Enfrentamento da Violência Sexual Infanto-Juvenil (2002), que foi revisado em 2010, o financiamento de projetos de prevenção e proteção de crianças e adolescentes em situação de exploração sexual por todo o país, a criação de uma comissão intersetorial em nível federal para o enfrentamento da exploração sexual de crianças e adolescentes, o apoio a projetos inovadores como o depoimento especial etc.

Mas a defesa dos direitos da criança se dá também por outro movimento, de cunho moralista e repressor, que defende medidas de recrudescimento do direito penal como solução para os problemas da criminalidade e adota bandeiras populares, e, aparentemente, contraditórias, como a diminuição da maioridade penal, a alienação parental, e, mais recentemente, a "luta contra a pedofilia".

O exemplo mais recente - e que diz respeito ao objeto deste trabalho, é o da promulgação da Lei 11829/08, que modificou os artigos 240 e 241 do ECA, discutidos no Capítulo 2, criminalizando novas condutas, especificando outras e aumentando penas .

Orientado por uma perspectiva de direitos das vítimas fortemente influenciada pelo movimento de caráter repressor, o processo de elaboração e aprovação da lei prescindiu do debate público e, principalmente, acadêmico a respeito do Projeto de Lei n.250/08, que deu origem à Lei 11.829, de 2008.

No Capítulo 2, ao discutir o conceito de pedofilia, transcreveram-se trechos de emails trocados entre os membros do Grupo de Trabalho da CPI da Pedofilia. Ao ler as 
mensagens, nota-se a ausência de advogados no debate ${ }^{499}$ (com exceção do Presidente da ONG Safernet Brasil que, como se verá abaixo, foi, em grande medida, o responsável pela elaboração do texto legal final ${ }^{500}$. Tampouco havia representantes dos movimentos e de ONGs de proteção de direitos das crianças e adolescentes ${ }^{501}$, dos Centros de Defesa de Crianças e adolescentes (ou de sua associação nacional, a ANCED), ou algum dos respeitados especialistas na temática da violência sexual contra crianças e adolescentes, alguns reconhecidos internacionalmente, ou representantes de institutos de caráter científico, como é o caso do IBCCrim.

Não se trata, de modo algum, de desmerecer os profissionais que compuseram o Grupo de Trabalho da CPI, ou de questionar sua seriedade e competência. Alguns, inclusive, têm formação acadêmica, e todos são respeitados como experts em suas áreas de atuação. Identifica-se, porém, a falta de uma promoção ativa do debate acadêmico e social amplo a respeito.

O que se nota, ao contrário, é uma lei promulgada a "toque de caixa", pois a intenção era que fosse um dos resultados da $\mathrm{CPI}^{502}$ :

\begin{abstract}
"O presidente da República, Luiz Inácio Lula da Silva, sancionou, no último dia 25 (...) lei que atualiza o Estatuto da Criança e do Adolescente (ECA). A lei é fruto do PL 250/08 proposto pela Comissão Parlamentar de Inquérito (CPI) da Pedofilia, que criminaliza, por exemplo, aquisição e posse de pornografia infantil na Internet.
\end{abstract}

O PL tinha sido aprovado no Senado em 10 de julho deste ano e na Câmara dos Deputados no último dia 11. A proposta de lei foi resultado de grande esforço de autoridades e especialistas

\footnotetext{
${ }^{499}$ A longo da CPI, os únicos advogados ouvidos foram os procuradores de provedores de serviço de internet (Tim, Oi, Vivo, Google, etc). Estiveram presentes, ainda, advogados de acusados de crimes diversos, ouvidos pela CPI. Não se localizou no texto do Relatório a oitiva de advogados de Centros de Defesa de Crianças e adolescentes (ou de sua associação nacional, a ANCED).

${ }^{500} \mathrm{O}$ que é, inicialmente, uma impressão, se confirma pela leitura da lista de participantes do Grupo de Trabalho constante do Relatório da CPI da Pedofilia.op. cit, p. 46-58.

${ }^{501}$ Lembrando que há, no Congresso Nacional, uma Frente Parlamentar de Defesa dos Direitos da Criança e do Adolescente, que não foi chamada a participar das discussões.

502 ECA: Nova Lei pune pornografia infantil pela Internet. Disponível em http://www.safernet.org.br/site/jornalistas/pauta/eca-nova-lei-pune-pornografia-infantil-pela-internet, consulta em 02 de março de 2012.
} 
que se debraçaram (sic) sobre as lacunas do ECA e propuseram soluções.

A participação da SaferNet na elaboração do projeto foi decisiva. Do estudo apresentado pela ONG no dia 2 de abril deste ano, durante audiência pública no Senado Federal, foi seguida rigorosamente na lei aprovada a estrutura para sistematização das condutas (divididas em produção, armazenamento, distribuição e fomento da demanda, além de outras propostas)."

[destaquei]

A edição da Lei 11.829/08 simboliza, claramente, esse segundo movimento, e encarna o que DOS SANTOS denomina de "paradigma da vitimização" ou "paradigma da tragédia", que é, no mais das vezes, importado da literatura internacional ${ }^{503} \mathrm{com}$ pouca ou nenhuma crítica (o que ocorreu claramente na CPI). Esta concepção denomina crianças e adolescentes vítimas deste tipo de violência como "sobreviventes da violência sexual" e concebe o fato vivido por elas como uma "tragédia". Os ofensores, evidentemente, são elevados à categoria de monstros ${ }^{504}$.

Foi, claramente, esta, a orientação que conduziu os trabalhos da CPI da Pedofilia e que resultou na mencionada lei. A orientação dos trabalhos foi encarada pelos Senadores como verdadeira cruzada ("Em nome de Deus eu recebo esta missão com temor e tremor" (...) "Eu tenho certeza que Deus vai nos ajudar nessa cruzada, porque essa cruzada é da sociedade" - Senador Magno Malta, p.10), que prestaria o "serviço educativo de limpar a sociedade brasileira desse tipo de desvio (...) prender esses monstrengos que deturpam e corrompem nossas crianças e nossos adolescentes" (Senador Demóstenes Torres ${ }^{505}$, p. 17), e eliminar esta "chaga que infesta a sociedade" (Senador Sérgio Zambiasi, p. 21).

\footnotetext{
${ }^{503}$ Notadamente a literatura dos países anglo-saxões.

${ }^{504}$ DOS SANTOS, Benedito Rodrigues. O enfrentamento da exploração sexual infanto-juvenil: uma análise de situação. Goiânia: Cânone Editorial, 2007; p.122.

${ }^{505}$ Não por acaso, esses mesmos parlamentares defendem projetos de lei para rebaixar a idade de imputação penal, baseados no fato de que os adolescentes "sabem exatamente o que estão fazendo".
} 
Trata-se de uma concepção que atribui a crianças e adolescentes vítimas de violência sexual características absolutamente passivas, ao mesmo tempo em que caracteriza os autores de violência sexual como doentes e perigosos, conforme já se mencionou no Capítulo 2, o que representa uma volta aos conceitos da Criminologia Positivista e da Doutrina da Situação irregular da Infância e Juventude.

Seria confortável contentar-se com esta dualidade de movimentos, aparentemente opostos. É preciso, porém, ter em conta que o tema da violência sexual contra crianças e adolescentes movimenta paixões que não distinguem orientações políticas de esquerda, direita ou centro.

Isso se revela, por exemplo, na análise que $\operatorname{CAMPOS}^{506}$ faz da legislação criminal e de segurança pública aprovada pelo Congresso Nacional entre 1989 e 2006. O autor afirma não ser possível identificar tendências específicas nas propostas dos partidos de esquerda conforme as categorias "leis que ampliam direitos, leis que criminalizam novas condutas ou leis mais punitivas e recrudescedoras". Fica evidente, contudo, pelo exame das leis analisadas pelo pesquisador, que as leis propostas pelos partidos de esquerda no período estudado são majoritariamente voltadas para a proteção de minorias.

Assim, forma de iniciativa dos partidos de esquerda leis protetivas às mulheres (Leis 10.778/03 - notificação de violência contra a mulher; 9046/95 - estabelecimentos prisionais; 9520/97 - direito de queixa; 10.224/01 - assédio sexual; 10.866/04 - violência doméstica; e 11.106/05 - exclusão do termo mulher honesta do CP); aos negros ( 7716/89 - crimes de preconceito e 9.459/97, que alterou o seu conteúdo); aos presos (8653/93 transporte de presos); aos vulneráveis (9777/98 - trabalho escravo e 11.106/05 - tráfico internacional e nacional de pessoas) e, finalmente, às crianças e adolescentes.

As duas leis protetivas de crianças e adolescentes de iniciativa dos partidos de esquerda no período estudado por CAMPOS tipificam condutas ligadas à violência sexual contra crianças e adolescentes: manter casa de exploração sexual infanto-juvenil (Lei 9975/00) e aumenta as penas para os crimes de pedofilia no ECA (Lei 10.764/03).

${ }^{506}$ CAMPOS, Marcelo da Silveira. Crime e Congresso Nacional: uma análise da política criminal aprovada de 1989 a 2006. São Paulo: IBCCRIM, 2010. p. (Monografias, 57).. 
KARAM $^{507}$ denominou os movimentos de interesse da esquerda pela repressão à criminalidade de esquerda punitiva: "reivindicações de extensão da reação punitiva a condutas tradicionalmente imunes à intervenção do sistema penal, surgindo fundamentalmente com a atuação de movimentos populares, portadores de aspirações de grupos sociais específicos, como os movimentos feministas que, notadamente a partir dos anos 70 , incluíram em suas plataformas de luta a busca de punições exemplares para autores de atos violentos contra as mulheres".

Embora o foco da autora sejam os brados pela repressão aos crimes de colarinho branco, ao crime organizado e à violência policial, suas observações podem ser aplicáveis às demandas por criminalização de movimentos sociais como os de defesa de crianças e adolescentes, o movimento negro etc. A esquerda punitiva, no entender da autora, parece se esquecer de todas as reflexões dos criminólogos críticos e penalistas progressistas, que identificaram o "sistema penal como um dos mais poderosos instrumentos de manutenção e reprodução da dominação e da exclusão, características da formação social capitalista".

Desse modo, ao invés de investir na busca das transformações sociais para o enfrentamento dos problemas, aderem a uma crença em um mítico "bom magistrado", juiz implacável e rigoroso, esquecendo-se que, no sistema capitalista, a punição dos membros das classes dominantes é tão somente um sacrifício excepcional realizado para "legitimar o sistema penal e melhor ocultar seu papel de instrumento de manutenção e reprodução dos mecanismos de dominação".

Em hipótese que dialoga com as ideias de KARAM, LANDINI ${ }^{508}$ identifica, primeiramente, que houve uma "descoberta do fenômeno da violência sexual" pelo setores da sociedade civil, e que a violência contra a criança passa a ser tematizada à partir da reação à violência contra a mulher, sendo fortemente impulsionado, portanto, pelo movimento feminista, que passa a focar a atenção na vitimização da mulher, ao invés de combater o machismo e o patriarcalismo (bandeiras anteriores do movimento feminista).

\footnotetext{
${ }^{507}$ KARAM, Maria Lúcia. A esquerda punitiva. Discursos Sediciosos: crime, direito e sociedade, Rio de Janeiro, v. 1, n. 1, p.79-92, 1996; p.79.

${ }^{508}$ LANDINI, Tatiana Savoia. Horror, Honra e Direitos: violência sexual contra crianças e adolescentes no século XX. Tese (Doutorado em Sociologia). São Paulo: Universidade de São Paulo, 2005.
} 
O que parece ficar claro, neste contexto um tanto nebuloso, é que a temática da violência sexual contra crianças e adolescentes tem um poder mobilizador que ultrapassa convicções políticas, já que tem forte apelo popular. A temática da proteção da criança mobiliza, igualmente, direita e esquerda, ricos e pobres; brancos, negros, mulheres e homossexuais; quem terá a coragem de a ela se opor $?^{509}$.

Ademais, esta temática mobiliza sentimentos psíquicos de cisão e projeção, por meio dos quais o indivíduo "divide" internamente as suas "coisas", suas vivências e tornaas como que independentes, divide o que é "bom" e o que é "mau" [cisão] (...) e "joga" para fora de si, "joga" no ambiente, nos outros (principalmente naqueles que mais se mostrarem apropriados para tal) o que existe de "mau" e inaceitável dentro de si [projeção]. O criminoso passa a ser então um concentrado de todos os males da humanidade, e a sociedade tem necessidade urgente de puni-lo severamente, prendê-lo, segregá-lo, pois assim estará punindo o que existe de ruim dentro dela (...) e estará expulsando e mantendo longe de si, "sob ferros", todas as suas coisas ruins". ${ }^{510}$ Desse modo, crianças e adolescentes (quando vítimas!) passam a representar o bem, e a pureza, e o "pedófilo", o mal encarnado.

No caso da violência sexual mediada pela TIC e condutas relacionadas, como a pornografia infantil, mais um elemento se agrega: a perplexidade diante do poder das novas tecnologias e o sentimento de insegurança que vem a ela aliado, alimentado e reforçado, também, pela mídia.

Não se pode afirmar, por outro lado, que essa perplexidade seja descabida. Como apontado por CASTELLS, são tempos confusos, os atuais, em que a humanidade experimenta um desenvolvimento tecnológico de proporções jamais vistas, que vem acompanhado por transformações sociais igualmente perturbadoras, tudo isso em curtíssimo período de tempo. A busca por soluções de curto prazo, que apaziguem a insegurança, como leis penais de caráter, muitas vezes, simbólico, acaba sendo a tônica de uma sociedade que vive num "tempo atemporal".

\footnotetext{
${ }^{509}$ Embora, como já dito, ela seja somente parcialmente adotada por alguns setores, que não hesitam em defender a redução da maioridade penal ao mesmo tempo em que pretendem proteger crianças da violência sexual.

${ }^{510}$ SÁ, Alvino Augusto de. Algumas Ponderações Acerca da Reintegração Social dos Condenados à Pena Privativa de Liberdade in Criminologia clínica e psicologia criminal. São Paulo: Editora Revista dos Tribunais, 2007. p.141-171.
} 
É por crer mais na solução preventiva do que na solução punitiva que a presente proposta se apresenta, buscando identificar elementos para compor medidas de prevenção que, atreladas a uma perspectiva vitimológica, possam navegar por entre esses movimentos, tentando encontrar o tênue equilíbrio entre a proteção dos direitos da criança e do adolescente e uma perspectiva de minimalista para o direito penal e a política criminal; buscando, a partir das palavras de BARATTA, uma proposta política que dependa menos da finalidade ou da função, mas sim da intenção subjetiva dos atores nela envolvidos ${ }^{511}$.

No contexto acima descrito, faz sentido a formulação do autor, ao qualificar como falsa a alternativa "segurança x política social", porque parte do conceito de segurança de direitos, que diz respeito a todos os sujeitos, e não somente àqueles detentores de direitos em detrimento dos seus infratores potenciais.

Posto que se parte de uma concepção de Vitimologia, Criminologia e Política Criminal "como parte de uma só disciplina, necessariamente articulada, e interessantemente abrangida pelo conceito dos direitos humanos" ${ }^{512}$, é intrínseca a esta proposta, como se estabeleceu desde o início, a interdisciplinaridade ${ }^{513}$, com todos os desafios que ela encerra. E se o objetivo é promover segurança ou política integral de defesa de direitos, conforme BARATTA, a interdisciplinaridade deve, obrigatoriamente, ir além do contexto das Ciências Criminais, incluindo, também, os Direitos Humanos.

A tarefa não é fácil, e envolve ainda um último e importante aspecto: as concepç̃es clínica e sociológica de Criminologia, ou os paradigmas do "fato social bruto x crime enquanto construção jurídico-social".

\footnotetext{
${ }^{511}$ BARATTA, op cit, p.58.

512 ANIYAR DE CASTRO, Lola. Direitos humanos: delinqüentes e vítimas, todos vítimas. Discursos Sediciosos: crime, direito e sociedade, Rio de Janeiro, 15 e 16, p.187-202, anual. 2007; p.189.

${ }^{513}$ Neste sentido, BARATTA, op. cit.,p. 63: o autor diferencia duas interdisciplinardades; no âmbito da definição, "o discurso integrado da ciência jurídico-penal (...) possu[i](em) um objeto que justifica epistemologicamente sua autonomia e sua competência para selecionar e organizar, dentro do próprio discurso, elementos de distintos saberes específicos ("interdisciplinariedade interna"); quando a criminologia e o discurso integrado da ciência jurídico-penal se dirigem às situações problemáticas [dimensão comportamental], cumprindo a função de controle externo do sistema, a referida autonomia e competência deixam de existir. Neste caso, cada uma das áreas problemáticas (...) necessita, sobretudo, da contribuição convergente de disciplinas acadêmicas e de conhecimentos especializados distintos para cada área, sem que nenhum deles possa por princípio exercer uma função hegemônica ou uma competência sobre a competência dos outros (...) [interdisciplinaridade externa]”.
} 
Como já se viu, em se tratando da violência sexual contra crianças e adolescentes, é fácil pender para o perigosismo e para a patologização do crime e, mais ainda, do criminoso ("o pedófilo").

A questão, porém, é complexa, pois, ao contrário de delitos cujas origens/existências são mais facilmente identificáveis como produto de atribuição de definição jurídico-penal (como, podemos pensar, o já abolido crime de adultério, no Brasil), há situações, especialmente aquelas em que ocorre violência, em que o fato social bruto está, inegavelmente, presente, por mais que seja possível compreender o poder da definição jurídica em sua criminalização e relativizar a ideia do bem-jurídico como universal. É o caso da violência sexual.

Ao mesmo tempo em que a violência sexual contra a criança existe (objetivamente, há o ator que, usando a definição de MACHADO, pratica ato sexual de relevo com (contra) a criança de modo precoce, deixando como resultado uma lesão atual ou potencial, que é verificável, sabe-se, também, que, conforme LANDINI e LOWENKRON, a "violência sexual contra crianças foi constituída, ao longo do século XX, enquanto um “problema" com contornos próprios e marcado por uma dramaticidade específica." 514.

Desta construção específica, todos participam: mídia, Estado, sociedade civil, individual e coletivamente. E a ideia de atribuição de status jurídico-penal a um fato social bruto vai além e se complexifica ainda mais quando entra em cena a TIC, a comunicação instantânea e sem fronteiras, a possibilidade do anonimato e outras características já discutidas, que tornam a atual sociedade em rede tão singular.

Tomando por base, talvez, somente o paradigma da atribuição do status jurídicopenal a uma conduta (que, na Criminologia, é inaugurado pelas teorias da reação social), seria possível entender (como discutido no Capítulo 2) que o abuso sexual on-line e o aliciamento on-line são condutas desprovidas de lesividade, não constituindo, portanto, fato social bruto digno de nota a ponto de merecer consideração no âmbito jurídico-penal.

\footnotetext{
${ }^{514}$ LOWENKRON, op cit.
} 
No entanto, os efeitos do abuso sexual on-line e do aliciamento on-line são reais e identificáveis, e podem atingir vítimas determinadas ${ }^{515}$. É imperativo, sim, considerar o fato de que a violência sexual contra crianças e adolescentes tenha sido, nos últimos anos, conceituada e reconceitualizada pelos movimentos sociais, e que o conceito do "pedófilo" e da "pedofilia" venham sendo construídos pela mídia ${ }^{516}$, o que se reflete claramente ao examinar a urgência e o contexto em que foi redigida, votada e promulgada Lei 11829/08.

Não se pode, porém, ignorar o fato de que crianças e adolescentes são reais vítimas de abuso sexual on-line, de aliciamento on-line, e que são violentadas, objetificadas e fetichizadas para a produção de imagens de pornografia infantil, e que, portanto, precisam ser protegidas. Este é um fato real, ainda que ele tenha sido estimulado por uma construção social coletiva da imagem do "pedófilo", ainda que se possa argumentar que se trata de uma "epidemia de pedofilia" construída pela mídia e estimulada pelo fácil acesso à tecnologia e às imagens de pornografia, num círculo vicioso. Ainda assim, o abuso existe, e suas vítimas são reais.

A ideia de garantia de segurança de direitos, proposta por BARATTA, dialoga com a proposta de ÁLVARO PIRES ${ }^{517}$, que vem sendo, no Brasil, articulada por $\mathrm{SÁ}^{518}$, de uma Criminologia das (inter-)relações sociais. A ousada proposta busca construir uma integração "entre dois projetos de conhecimento: a genealogia dos comportamentos e a constituição das práticas sociais institucionalizadas" ${ }^{519}$, levando-se, portanto, em conta, o comportamento concreto e a reação social diante desse comportamento.

\footnotetext{
${ }^{515}$ Poder-se-ia também, então, argumentar que a interpretação dos efeitos também passa por uma atribuição de sentido e, portanto, não se pode considerar, de modo algum, o abuso sexual on-line como fato social bruto. De fato, a interpretação dos efeitos passa SEMPRE por uma atribuição de sentido. Esta, porém, é uma característica da existência humana, sendo o que diferencia o ser humano, na essência, dos outros animais. Assim, toda lesão física é um fato social bruto (houve rompimento da pele e sangue derramado), mas atribuise a essa lesão sentidos diferentes, conforme o contexto em que foi produzida (ao furar a orelha ou o nariz para colocar um adorno, ao passar por um rito de iniciação ou realizar um pacto, ao fazer uma tatuagem, ao se automutilar, ao participar de uma relação sexual sadomasoquista, ao levar um soco ou uma facada, ao se forçada a praticar contra a própria vontade, ato sexual).

${ }^{516}$ LANDINI, op cit; LOWENKRON, op cit.

517 Alvaro PIRES é professor do Departamento de Criminologia da Faculdade de Ciências Sociais da Universidade de Ottawa/Canadá.

${ }^{518}$ SÁ, Alvino Augusto de. Criminologia Clínica e Execução Penal. Proposta de um modelo de Terceira Geração. Revista dos Tribunais. 2011.

${ }^{519}$ PIRES, Alvaro P. La criminologie et ses objets paradoxaux: réflexions épistémologiques sur un nouveau paradigme. Déviance et Société, v. 17, n. 2, p. 129-161, 1993; apud SÁ, op cit, p. 257.
} 
Como visto acima, diante do estranho, do diferente, identificamo-lo como uma ameaça (o que leva ao acionamento dos mecanismos psíquicos de cisão e projeção). Aciona-se no ser humano o instinto de defesa, que "nos impede de ter uma visão mais profunda e mais integral do outro, de suas qualidades que vão além da vontade e da responsabilidade. Aliás, quanto maior é a sensação de insegurança (percepção de riscos), mais ela reativa nosso instinto de defesa (...) graças à qual a sociedade é dividida em dois grupos: o dos que têm qualidades e o dos que têm defeitos. (...) Ora, se a sociedade reage diante do comportamento problemático levada por seu instinto de defesa, interpretando-o como hostil e tendendo a reduzir e aniquilar o seu autor, não se pode deixar de considerar esta atitude como elemento constituinte do cenário do crime. ${ }^{, 520}$.

No contexto de uma política integral de defesa de direitos, proposta pelo criminólogo italiano, no contexto de uma Criminologia (e, portanto, de uma Vitimologia e de uma Política Criminal, visto que são saberes que não se divorciam) das (inter)-relações sociais, é preciso ter em conta não só as situações problemáticas de violações de direitos fundamentais dependentes de comportamentos de pessoas físicas, mas também os processos de criminalização e as consequências individuais e sociais das violações de direito e dos processos de criminalização.

Desse modo, num contexto de prevenção vitimal, torna-se relevante considerar, por exemplo, as definições e conteúdos referentes não só à violência sexual contra crianças e adolescentes, mas também o tratamento em nível de definição que se dá aos atores envolvidos com a (na) violência sexual contra crianças e adolescentes.

Ao mesmo tempo, com estes pressupostos em mente, ao eleger como sujeitos de uma reflexão a respeito de prevenção vitimal as crianças e os adolescentes, é preciso tomá-los em consideração em sua complexidade, o que implica em uma reconfiguração da tradicional visão (acima apresentada) que as Ciências Criminais Integradas têm a respeito delas.

${ }^{520}$ SÁ, op cit, p. 261-263. 


\subsection{Crianças e adolescentes vítimas no paradigma das (inter)-relações sociais.}

Quando se toma como ponto de partida uma proposta vitimológica/criminológica/político-criminal integrada com os Direitos Humanos, não é mais possível conceber crianças e adolescentes como incapazes e completamente indefesos.

Não se trata de negar, como já dito anteriormente, que necessitem de atenção, orientação e cuidado (razões de ser da presente pesquisa). Trata-se, porém, de considerar, na reflexão, na proposta e, principalmente, na ação, que são sujeitos de direitos complexos, sendo necessário ter em conta sua realidade social, a interação com seus pares e com o uso da TIC e dos fatores biopsicossociológicos de seu desenvolvimento (além da dinâmica de sua interação com o ator envolvido com a (na) violência sexual).

É preciso despir-se da ótica da moralidade, que "ainda dita muito os termos das interpretações jurídicas sobre práticas sexuais" ${ }^{" 521}$, em especial quando se trata da relação de crianças e adolescentes com a sexualidade. "A partir da afirmação da afirmação da subjetividade jurídica de crianças e adolescentes e da reflexão sobre os novos espaços sociais abertos à infância e à adolescência, abre-se ao desafio de pensar, no campo da sexualidade, os termos da cidadania de crianças e adolescentes pela afirmação de seu direito ao desenvolvimento sob o marco dos direitos humanos, numa renovada tentativa de fundamentação da justiça".

Para MELO, o grande desafio é superando-se, o paternalista paradigma das necessidades (e da proteção), já referido aqui sob o nome de tutelar ou de Paradigma da Situação Irregular, compreender crianças e adolescentes a partir de seus próprios interesses, o que implica no reconhecimento de seu protagonismo (ou, nos termos aqui propostos, de sua capacidade de participação), empoderando-as no contexto de sua própria proteção. Para isso, é preciso tomar esses sujeitos como ponto de referência primário, repensando-se as dimensões jurídicas e políticas de afirmação de direitos humanos de crianças e adolescentes para afirmação de novos espaços sociais a elas e superando os “estereótipos do que seja a capacidade para exercício de direitos por crianças e

\footnotetext{
${ }^{521}$ MELO, Eduardo Rezende. Direito e Norma no campo da sexualidade na infância e na adolescência. In UNGARETTI, Maria America (org.). Criança e adolescente: direitos, sexualidades e reprodução. São Paulo; ABMP; 2010; p. 43-59; p. 44-45.
} 
adolescentes em certas faixas etárias, tanto no estabelecimento de limites coletivos em comparação com adultos como também das próprias crianças e adolescentes entre si, que devem ter sua singularidade individual e social respeitada",522.

A perspectiva adotada por MELO advoga por uma mudança na abordagem das questões ligadas à sexualidade de crianças e adolescentes, que não se foque apenas no controle e na repressão da violação de direitos, mas que condicione o exercício desses direitos pela educação sexual, pelo direito à diversidade e à privacidade, não ignorandose, contudo, a existência de riscos ao se reconhecer as competências e a possibilidade de exercício de direitos por parte de crianças e adolescentes.

Para o autor, "melhora-se a capacidade de exercício de competências aumentando ativos pessoais de crianças e adolescentes para lidar com o sistema ou fazendo com que as escolhas dentro do sistema se tornem menos irreversíveis. Isso se faz pela diminuição de riscos com as escolhas, pelo controle do ambiente a nível coletivo, aumentando-se a competência individual para decidir",523.

O desenvolvimento de competências passa, necessariamente, pela promoção do direito à participação, conforme examinado no Capítulo 3, participação esta que deve contemplar as singularidades das crianças e adolescentes: relação com o desenvolvimento (idade), gênero (meninas são mais vulneráveis, especialmente em situações ligadas à sexualidade), classes sociais (crianças/adolescentes em situação de pobreza tendem a ser mais vulneráveis), geografia (há locais onde as condições de vulnerabilidade são maiores que outros).

Para tanto, é necessário ouvir, verdadeira e atentamente, crianças e adolescentes, pois somente esta escuta proporciona aos adultos, responsáveis pela promoção de seu desenvolvimento, o acesso às suas vivências e realidades. Os estereótipos que compõem determinadas concepções sobre o que é ser criança e o que é ser adolescente e sobre as vivências desses sujeitos em situações específicas (como o trabalho sexual) somente podem ser confirmados ou refutados a partir da disposição de ouvi-los.

${ }^{522}$ MELO, op cit, p. 49.

${ }^{523}$ MELO, op cit, p. 54. 
Na garantia do direito à participação está, ainda, abrangido, o direito à informação. Empoderar crianças e adolescentes para sua autoproteção, possibilitando-se, conforme MELO, o exercício de competências, implica em informá-los a respeito de benefícios e riscos; de canais de cuidado e atenção; e em estimulá-los a fazer uso dos recursos disponíveis sempre que sentirem necessidade.

A compreensão do processo de seu desenvolvimento e do significado da participação enquanto direito e enquanto parte essencial desse processo deixa claro que as ideias de crianças e adolescentes como seres humanos incapazes de entender o que acontece à sua volta e de fazer escolhas; fantasiosos, irresponsáveis e impulsivos; incapazes de avaliar riscos, de tomar decisões e de se responsabilizar pelos seus atos não podem mais persistir em uma Vitimologia integrada aos Direitos Humanos, no paradigma das (inter)-relações sociais.

Ao mesmo tempo, há inúmeras e complexas nuances nesse processo, sendo que elas serão afetadas por questões que incluem o desenvolvimento neurológico individual, as condições socioeconômicas que vivenciam crianças e adolescentes, as demandas e acontecimentos da vida, as oportunidades e desafios que lhes são apresentados.

Ao se considerar crianças e adolescentes no contexto de seu desenvolvimento sexual, é preciso ter em conta que a sexualidade é parte integrante e necessária do desenvolvimento humano. A visão psicanalítica, aliás, a coloca como central para a formação de um indivíduo capaz de conviver socialmente, e identifica o seu início desde a infância. A neurologia demonstra o quanto este é um processo absolutamente natural e universal. E a psicologia, a sociologia e antropologia e outras ciências indicam que estas e outras experimentações fazem parte do processo de autodescoberta do adolescente no mundo, processo este que se dá no âmbito individual e coletivo.

Enquanto a introdução da dimensão ética e do (auto-)respeito são imprescindíveis no desenvolvimento de competências de crianças e adolescentes, deve-se evitar, por outro lado, o julgamento moral, sob pena de reforçar estigmas e preconceitos a respeito da sexualidade, ao invés de promover a liberdade e a confiança.

Uma Vitimologia integrada à Criminologia, à Política Criminal, aos Direitos Humanos de Crianças e Adolescentes, num paradigma das (inter)-relações sociais deve, 
portanto, considerar crianças e adolescentes como sujeitos de direitos capazes de compreender as questões que lhes dizem respeito e delas serem partes informadas, consideradas as especificidades de seu momento de vida e de sua realidade social, econômica e cultural.

\subsection{Vitimização enquanto processo: coparticipação de crianças e adolescentes na dinâmica da violência sexual mediada pela TIC}

O exame da dinâmica da violência sexual mediada pela TIC, conforme apresentada no Capítulo 2, permite identificar claramente a sua natureza de processo que se desenrola entre vítima e vitimário (ou autor do fato). Especificamente, entre criança/adolescente e adulto envolvido com a (na) violência sexual.

Conforme SÁ, há um processo, identificável, pelo qual alguém se torna ou é eleito a tornar-se alvo da violência por parte de outrem. Como processo que é, a vitimização implica uma "rede de ações/omissões, interligadas entre si, dotadas de um caráter de historicidade e dinamizadas por interesses, ideologias e motivações conscientes ou inconscientes. ${ }^{524,}$

Longe de ser mero objeto de ação por parte do autor, a visão da vitimização enquanto processo coloca a vítima como copartícipe da dinâmica, ao longo da qual se pode desenvolver uma cumplicidade entre as partes.

No caso da violência sexual mediada pela TIC, a visão de crianças e adolescentes a partir de uma ótica tutelar e/ou a partir de uma Vitimologia baseada no positivismo, já mencionada, as torna ao mesmo tempo, completamente indefesas diante de um possível abusador, já que ignora o papel ativo que desempenham na dinâmica do abuso ou do aliciamento on-line. É a visão que claramente orienta falas como as acima transcritas, dos participantes da CPI da Pedofilia, em que se expressa uma visão dicotômica da infância e da adolescência: ora são anjos, ora perturbadores da ordem social, necessitando ou de tutela ou de punição ${ }^{525}$.

524 SÁ, Alvino Augusto de. Algumas considerações psicológicas sobre a vítima e a vitimização. In Vitimologia no terceiro milênio. Elida Séguin (coord). Rio de Janeiro: Forense, 2004; p. 11-24; p. 12.

${ }^{525}$ Essas concepções oscilam entre as teorias de caráter tutelar, discricionárias e subjetivistas (que permitem todo e qualquer tipo de intervenção "em favor e para o bem do menor") - que remetem à Doutrina da 
Admitir a participação da vítima criança e adolescente na dinâmica do abuso sexual e do aliciamento on-line não significa desresponsabilizar o adulto envolvido com a (na) violência sexual e, menos ainda, culpabilizar a criança/adolescente pelo abuso sexual sofrido, mas sim reconhecer que há um espaço para o empoderamento da vítima, com vistas à tomada de consciência de sua situação, levando à sua autodefesa. Reconhece-se, assim, a posição de crianças e adolescentes como sujeitos de direitos, em processo de desenvolvimento, capazes, conforme suas circunstâncias individuais e sociais, de entender e interpretar o mundo, avaliar riscos e tomar decisões (sempre orientadas e supervisionadas por adultos, é bom não esquecer).

Esta é a razão pela qual interpretações como a de $\mathrm{SYDOW}^{526}$, ao pretender corresponsabilizar os pais de crianças e adolescentes pelo aliciamento e abuso sexual online, desresponsabilizando o adulto envolvido na violência sexual, e ignorando a participação de crianças e adolescentes na dinâmica, ao contrário de se filiar a uma perspectiva integradora, reforça os estereótipos a respeito da vítima e do "pedófilo", assumindo implicitamente que este seria quase incapaz de se controlar e que caberia aos pais tutelar os seus filhos, mantendo-os em segurança, já que "há notoriedade acerca do fato de que conteúdos pornográficos de todos os estilos permeiam a rede". O argumento lembra o velho dito popular em que o pai de um "varão" recomendava aos pais de mocinhas solteiras (e, evidentemente, indefesas), que "guardem suas cabras, que meu bode está solto".

A ideia de vitimização enquanto processo faz lembrar, ainda, da clássica denominação vitimológica denominada de "dupla penal" ${ }^{27}$, que admite que possa haver

Situação Irregular - e as teorias retribucionistas, que encontram na juventude delinqüente a causa do aumento da criminalidade nas grandes cidades brasileiras e propõem, como panacéia para acabar de uma vez por todas com a criminalidade crescente, a redução da idade penal e o encarceramento precoce de jovens. GARCÍA MÉNDEZ, Emilio. Adolescentes e responsabilidade penal: um debate latino americano. Porto Alegre: AJURIS, ESMP, FESDEP, 2000. Disponível em www.abmp.org.br. Acesso em 11/jun/06).

${ }^{526}$ Cf. Capítulo 2, item 2.2.4.

${ }^{527}$ Seria possível também apresentar, neste momento, a posição de crianças e adolescentes vítimas de violência sexual a partir das tradicionais tipologias de vítimas, comuns em obras de Vitimologia. Por exemplo, MENDELSOHN apresenta uma categorização das vítimas conforme uma "gradação de culpa", em "vítimas inocente ou ideal", "vítima provocadora, imprudente, voluntária e ignorante", "vítima agressora, simuladora e imaginária"; outras tipologias comumente referidas são as formuladas por HENTIG, JIMÉNEZ DE ASÚA, e ANIYAR DE CASTRO. Opto aqui, por não apresentar tal tipologia por três razões: a uma, porque as considero redutoras de dinâmicas complexas; se servem bem para fins didáticos, são limitadas na análise de situações reais; a duas, porque pesquisadores bem mais versados em Vitimologia do que autora, como o próprio BITTENCOURT, cuja obra Vítima foi consultada para citar tais tipologias, não só se limita a dedicar três páginas de sua obra que versa exclusivamente sobre Vitimologia às tipologias, considera que 
coadjuvação inconsciente, por parte da vítima, na dinâmica do fato. "Esta concepção traz como consequência que a vítima adquire relevante preponderância no estudo do delito e que se elimine o critério que a reduziria à condição de passiva receptora da ação delituosa. E assim igualmente se destrói a insuficiente afirmação de que só o delinquente pode decifrar o problema do crime, sem considerar que sua existência como tal só é possível com a correlata existência da vítima e que toda ação dirigida única e exclusivamente ao delinquente fundar-se-á sobre bases falsas." 528

A admissão da vitimização enquanto processo leva, naturalmente, à reflexão a respeito do consentimento da vítima que, no âmbito jurídico, pode levar a uma diminuição na culpabilidade do autor. Esta questão está abarcada no campo de estudos denominado de Vitimodogmática que, embora não integre o objeto do presente trabalho, merece menção, ainda que breve.

Com efeito, o artigo 59 do Código Penal, somente para citar um exemplo, estabelece que, no momento da fixação da pena, o juiz deverá atender à "culpabilidade, aos antecedentes, à conduta social, à personalidade do agente, aos motivos, às circunstâncias e consequências do crime, bem como ao comportamento da vítima, estabelecerá, conforme seja necessário e suficiente para reprovação e prevenção do crime." [destaquei]

Além disso, a teoria da imputação objetiva, desenvolvida por penalistas alemães e que tem influenciado fortemente a doutrina brasileira, tem enfatizado a relevância do comportamento da vítima para a tipicidade. Antes que se chegue, porém, à conclusão de que é possível desresponsabilizar o ator envolvido com a (na) violência sexual contra criança e adolescente mediada pela TIC, com base na participação da vítima na dinâmica delituosa, é bom notar que "não haverá exclusão da imputação caso a vítima seja irresponsável, havendo acalorada controvérsia a respeito de se aqui os critérios devem ser

\footnotetext{
"na classificação da vítima, não há omitir a que concerne à idade; a tal respeito, reporto-me ao n. 6_B, sobre a vitimização da criança", indicando, portanto, que o só fato de a vítima ser criança já consistiria em uma "categoria" de vítima separada das demais (BITTENCOURT, Edgard de MOURA. Vítima. $3^{\circ}$ Edição. São Paulo: Universitária de Direito, 1987, p. 91); a três, porque além de as vítimas aqui estudadas já serem, portanto, "categorizáveis" a partir da idade, a abordagem principal se foca na "potencialidade" ou "virtualidade" de sua vitimização, o que já as inseriria em uma segunda categoria, conforme CÂMARA, qual seja, a de vítimas "virtuais" (no sentido de potenciais). CÂMARA, op cit., p. 111 e ss.

${ }^{528}$ BITTENCOURT. op cit,; p.39.
} 
os da capacidade para consentir ou os da culpabilidade (exemplo incontroverso, porque comum a ambas as opiniões: a vítima é uma criança) (...) ${ }^{\text {,529. }}$.

Em se tratando de criança (sujeito menor de 12 anos de idade, conforme definição do ECA), a posição parece ser pacífica na doutrina que trata de crimes sexuais contra a criança/adolescente. Há divergências, porém, quando a vítima é adolescente.

Conforme já mencionado no Capítulo 2, a questão da validade do consentimento se confunde com a presunção de violência, objeto de divergência no tocante a adolescentes. Estudando detalhadamente a temática, MACHADO, em primeiro lugar, propõe a substituição da imprecisa categoria da presunção de violência pela da presunção de lesividade: "a lesividade de um ataque sexual concreto contra crianças e adolescentes há de ser analisada essencial, ou quase que exclusivamente, à luz dos direitos fundamentais da vítima (...) [já que] é de baixa significância, para o adulto, o dever de abstenção da prática de ato sexual de relevo contra (ou com) crianças e adolescentes, porque pode exercitar livremente sua sexualidade em relação aos demais adultos; são de altíssima significância para a integridade da vítima, as consequências do abuso, da violência ou da exploração sexual" ${ }^{\prime 30}$.

E com relação à questão do consentimento, pondera, corretamente:

\begin{abstract}
"veja-se que, em outros crimes graves contra a pessoa, mesmo quando a vítima é adulta (e, portanto, a validade jurídica da vontade é presumida pela lei), também é inadmissível redução desse tipo de questão ao ponto validade da vontade ou do consentimento: no Estado Democrático de Direito, não se quebra a presunção legal de lesividade (ínsita na proibição penal ou no tipo, se se quiser), quando o adulto "consente" com a escravidão ou com a privação da liberdade penalmente típica ou, quando o adulto "consente" em ser submetido à lesão corporal grave ou gravíssima, ou "consente" na própria morte.
\end{abstract}

E também se faz necessário ressaltar que a lesividade específica dos crimes sexuais contra crianças e adolescentes retira qualquer relevância jurídica de fatores como "corrupção da vítima" ou "innocentia consilii" ${ }^{\text {"31. }}$ [itálicos no original]

\footnotetext{
${ }^{529}$ GRECO, Luís. Um Panorama da Teoria da Imputação Objetiva. Rio de Janeiro: Lumen Juris, 2005; p. 70.

${ }^{530}$ MACHADO, op. cit, p.204-205; 194

${ }^{531}$ MACHADO, op. cit., p. 194.
} 
Com isso, a autora evidencia, em meu entender, o quanto juízos de valor e preconceitos estão inseridos na discussão da questão da violência sexual (contra adultos e, principalmente) contra crianças e adolescentes.

Assim, apesar de ser clara a necessidade de participação da vítima criança e adolescentes na dinâmica da violência sexual mediada pela TIC para que o abuso sexual ou o aliciamento on-line se consumem, esta constatação não pode justificar, a priori (e, jamais, nos casos em que a lei estabelece a proibição etária - abaixo de 14 anos), uma interpretação vitimodogmática que signifique a automática exclusão da responsabilidade do adulto, pois há uma presunção de lesividade na conduta do adulto que pratica ato sexual de relevo com (contra) criança/adolescente ${ }^{532}$.

A constatação da participação necessária de crianças e adolescentes na dinâmica da violência sexual mediada pela TIC somente pode justificar, pois, a adoção de medidas positivas de empoderamento de crianças e adolescentes para sua autoproteção, reconhecendo-se, assim, a sua posição como sujeitos de direitos, em processo de desenvolvimento, capazes, conforme suas circunstâncias individuais e sociais, de entender e interpretar o mundo, avaliar riscos e tomar decisões.

\subsection{Prevenção Vitimal no âmbito da Vitimologia integrada aos Direitos Humanos e no paradigma das (inter)-relações sociais.}

Estabelecidas estas premissas, o próximo passo é identificar quais aspectos devem ser levados em conta no estabelecimento de medidas de prevenção vitimal, e em que níveis se estruturam tais medidas.

O exame de literatura específica sobre prevenção indica que são componentes essenciais de qualquer programa a identificação de fatores de risco (ou de vulnerabilidade) e fatores de proteção.

\footnotetext{
532 Para mais detalhes, remeto ao Capítulo 2, item 2.1. e à obra de MACHADO, Martha de Toledo, Proibições de excesso e proteção insuficiente no direito penal: as hipóteses dos crimes sexuais contra criança e adolescentes. São Paulo: Editora Verbatim, 2008.
} 
A multissetorialidade é outra característica de programas de prevenção vitimal bem sucedidos, em especial em se tratando de crianças e adolescentes.

A literatura vitimológica aponta para a necessidade de problematizar a questão da promoção do medo do crime $x$ consciência do risco.

Por fim, a atuação em três níveis: primária, secundária e terciária.

Cabe examinar, portanto, cada um desses aspectos, iniciando-se pelo modelo da ecologia social (ou modelo ecológico do desenvolvimento), que propõe uma abordagem teórico-prática multissetorial e engloba os conceitos de fatores de risco/vulnerabilidade e fatores de proteção.

\subsubsection{Multissetorialidade: Modelo da Ecologia Social dos Direitos da Criança e do Adolescente e Sistema de Garantia de Direitos (SGD)}

O modelo da ecologia social é referenciado na literatura como um referencial importante para o desenvolvimento de medidas de prevenção. Também chamado de modelo ecológico do desenvolvimento ${ }^{533}$, é utilizado para a compreensão do fenômeno com o qual se está lidando, a partir da identificação dos sistemas nos quais o sujeito - no caso, crianças e adolescentes, estão inseridos, do nível micro ao macro. ${ }^{534}$

Compreender a ecologia social da criança e do adolescente significa, conforme o modelo da ecologia social, identificar:

- "Os micro-sistemas - família e escola, sistemas nos quais a criança está diretamente envolvida.

- Os exo-sistemas - o trabalho dos pais, por exemplo, que afetam o bem-estar das crianças.

\footnotetext{
${ }^{533}$ O nome em inglês é Ecology Model, de modo que a tradução acaba variando, sem que haja grande perda de significado.

${ }^{534} \mathrm{O}$ modelo da ecologia social dialoga com outras propostas metodológicas para intervenção social, como modelos de redes sociais que, similarmente, buscam identificar as redes individuais e organizacionais em que a criança/adolescente está inserida para, a partir da identificação desses atores e de seus papéis de proteção e risco, propor intervenções para a mudança social. $\mathrm{Cf}$, a respeito do modelo de redes sociais, SANICOLA, Lia. O trabalho com redes sociais. Trad. Durval Cordas. São Paulo: Veras Editora, 2008.
} 
- Os macro-sistemas - a cultura, o contexto e a sociedade em que a criança vive" ${ }^{353}$.

No cerne da ecologia social está a ideia de que não há um único fator determinante para a ocorrência, por exemplo, de uma situação de abuso sexual. Se o desenvolvimento é um processo complexo (como visto no Capítulo 4 deste trabalho), e se pretende adotar medidas para a prevenção de situações que impactem de modo significativo ${ }^{536}$ este processo, essas medidas precisam levar em conta a complexidade dos atores, instituições, sistemas, que fazem parte das vivências de crianças e adolescentes.

A abordagem da autora parte de uma perspectiva da saúde, em nível individual e coletivo, e tem como foco específico as intervenções após a ocorrência de dano significativo ao desenvolvimento da criança/adolescente, em virtude de abuso.

Também partindo do modelo de BROFENBRENNER ${ }^{537}$ (1979), o IICRD propõe uma aproximação ao modelo da ecologia social com ênfase na participação, adicionando

${ }^{535}$ LIDCHI, Victoria Gabrielle. Fatores de Risco e de Proteção: modelo ecológico do abuso de crianças e adolescentes. In WILLIAMS, L. C. A. (Org.); PADOVANI, Ricardo da Costa (Org.); ARAUJO, Eliane A C (Org.); STELKO-PEREIRA, A. C. (Org.); ORMEÑO, Gabriela Isabel Reyes (Org.); EINSTEIN, E. (Org.). Fortalecendo a Rede de Proteção da Criança e do adolescente. São Carlos: Pedro e João Editores, 2010; p. 47-54; p. 47. A autora referencia as seguintes obras como fontes de consulta: BROFENBRENNER, U (1979). The Ecology of Human Development. Cambridge, MA: Harvard University Press; BELSKY, J. (1980). Child Maltreatment: An Ecological Integration. American Psychologist, 35,320-335. ; BELSKY J. (1993). Aetiology of Child Maltreatment: A Developmental-Ecological analysis. Psychological Bulletin, 114: 413-434; GABARINO, J., STOTT, F.M. and the Faculty of the Erickson Institute. (eds).1989. What children can tell us. Jossey Bass: New York.

${ }^{536}$ Friso a questão do impacto significativo porque, evidentemente, em virtualmente todo processo de desenvolvimento, haverá situações e vivências que impactarão, de modo mais ou menos intenso, o que se poderia considerar com um processo de desenvolvimento "perfeitamente saudável". O modelo da ecologia social poderia servir para mapear o desenvolvimento em qualquer momento da vida de uma pessoa, inclusive para identificar fatores que levam ao "sucesso"; porém a sua aplicação costuma se dar para a prevenir ou interferir quando um impacto significativo negativo, que possa interferir de modo relevante no desenvolvimento, pode ocorrer ou já ocorreu.

${ }^{537}$ Urie Bronfenbrenner, pesquisador de origem russa radicado nos EUA e que foi professor da Universidade de Cornell desde 1948 até sua morte, em 2005, é referenciado como um dos mais renomados estudiosos da psicologia do desenvolvimento, e da ecologia humana, e considerado um dos poucos autores capazes de construir propostas compreensivas que interrelacionassem pesquisa e política de desenvolvimento da criança. Antes dele, "psicólogos estudavam a criança, sociólogos examinaram a família, os antropólogos, a sociedade, os economistas o contexto econômico e os cientistas políticos, a estrutura". O conceito inovador de Bronfenbrenner da ecologia do desenvolvimento humano, integra esses ambientes - desde a família até estruturas econômicas e políticas. "Esse modelo teórico transformou a abordagem de muitos cientistas sociais e comportamentais a respeito do estudo dos seres humanos e seus ambientes", o que "levou a novos rumos para a pesquisa básica e aplicações na concepção de programas e políticas que afetam o bem-estar das crianças e famílias". LANG, Susan S. Urie Bronfenbrenner, father of Head Start program and pre-eminent 'human ecologist,' dies at age 88. Cornell University News Service, Sept. 26, 2005. Disponivel em http://www.news.cornell.edu/stories/Sept05/Bronfenbrenner.ssl.html, consulta em 15.03.2012. 
"uma lente de desenvolvimento centrada em direitos e pontos fortes, e baseada na cultura".

O modelo desenvolvido pelo IICRD é fortemente centrado na criança/adolescente, e inclui:

- "o mundo interior da criança/adolescente (cognitivo, emocional e espiritual);

- os mundos externos da criança e do adolescente (físico, social, comportamental);

- seus pares/outras crianças e adolescentes;

- famílias;

- comunidades e ambientes naturais e construídos;

- sociedade civil, governo e organizações nãogovernamentais;

- fatores culturais, sociais, econômicos, cívicos e políticos" ${ }^{338}$.

Em qualquer abordagem que se adote, tendo como ponto de partida a ecologia social, identifica-se que indivíduos ou sistemas com os quais a criança/adolescente se relaciona influenciam o seu desenvolvimento; além disso, a maior ou menor interação entre esses sistemas também terá impacto sobre o desenvolvimento.

Segundo LIDCHI, o modelo ecológico "agrupa e permite a investigação da interação entre várias variáveis de influência, como as dos níveis individuais, genéticos, biológicos, psicológicos e do sistema familiar (...) [variáveis que podem] agir como fatores capacitantes (protetoras) ou como fatores limitantes (riscos) do desenvolvimento humano." 539

Em seu modelo, o IICRD enfatiza a "identificação de riscos e lacunas específicos relacionados aos direitos, e enfatiza oportunidades de fortalecer ainda mais os sistemas de proteção e apoio às crianças, adolescentes e jovens" ${ }^{540}$, partindo das realidades vividas por

\footnotetext{
${ }^{538}$ CURRIE, Vanessa. Série de Manuais do Círculo dos Direitos da CPP: Planejamento Reflexivo para Mudança Social. Tradução: Viviane Fontoura; Coordenação e Revisão Técnica da edição brasileira: Maria Emilia Accioli Nobre Bretan. Victoria/BC: International Institute for Child Rights and Development, 2011 (no prelo); p. 16.

${ }^{539}$ LIDCHI, op cit, $\mathrm{p} 47$.

${ }^{540}$ CURRIE, op cit, $\mathrm{p} 16$.
} 
crianças e adolescentes para propor intervenções do nível micro ao nível macro, enfatizando as relações entre os sistemas.

Ao partir da realidade da criança e do adolescente, o IICRD busca construir um modelo da ecologia social capaz de influenciar políticas públicas, enfatizando a conexão entre sistemas, com o objetivo de promover mudança sistêmica.

Com a identificação de fatores de proteção e de risco, em cada sistema, a partir da realidade de crianças e adolescentes, atividade realizada em grupo, é possível mapear a ecologia social de grupos de crianças/adolescentes, que são, posteriormente, compartilhadas com os atores da ecologia social, em um nível micro (família, amigos, escola), incluindo-se, em seguida, a comunidade, o setor privado, e o governo (instituições de proteção em nível comunitário, local, estadual e federal), em um movimento ascendente.

A cada passo do processo, "camadas" mais complexas de ação e interação sistêmica vão sendo acrescentadas, buscando-se, como resultado final, sistemas integrados de proteção à criança e adolescente que possam, efetivamente, promover seus direitos, sendo que a articulação entre os sistemas é feita em cada nível.

Desse modo, ao se atingirem os níveis mais altos, é possível influenciar órgãos governamentais formuladores e executores de políticas públicas, em um movimento descendente, medidas de proteção concebidas com base nas realidades de crianças e adolescentes são estabelecidas e aplicadas, tanto em nível preventivo quanto em nível de intervenção após a prática de ato prejudicial ao desenvolvimento, em um movimento permanente de retroalimentação.

Apesar de mais focada na intervenção e partindo de uma perspectiva do sistema de saúde, LIDCHI também identifica a possibilidade de utilização do modelo ecológico de desenvolvimento com objetivos preventivos, com enfoque na comunidade e multissetorial (abordagem de saúde pública). A ênfase está no empoderamento das famílias para cuidar de seus filhos, tanto em nível da intervenção individual após eventual dano significativo ao desenvolvimento, quando em nível coletivo, em programas de prevenção. Segundo a 
autora, "prioridade deve ser dada aos programas que são orientados a desenvolver as capacidades dos pais para cuidar das crianças ou os adolescentes dentro da família." 541

A abordagem do IICRD, por seu turno, embora reconhecendo o papel central da família na promoção do desenvolvimento de crianças e adolescentes, coloca crianças e adolescentes no centro do processo, promovendo o direito à participação, conforme estabelecido na CIDC. Apesar de o modelo ser compatível também com a intervenção após o dano, apresenta uma proposta metodológica, denominada Círculo dos Direitos, focada especialmente na prevenção como ponto de partida para a formulação de políticas que, posteriormente, incluirão também ações de intervenção.

Ambas as abordagens dialogam não só com o ECA (lembremos dos Princípios da Prioridade Absoluta e da Proteção Integral ${ }^{542}$, que marcam o novo paradigma) e com o Sistema de Garantia Direitos da Criança e do Adolescente (SGD), assim definido a partir da Resolução no 113/2006 do Conanda ${ }^{543}$ : “a articulação e integração das instâncias públicas governamentais e da sociedade civil, na aplicação de instrumentos normativos e no funcionamento dos mecanismos de promoção, defesa e controle para a efetivação dos direitos humanos da criança e do adolescente, nos níveis Federal, Estadual, Distrital e Municipal."

${ }^{541}$ LIDCHI, op cit, p 53. A opção se faz porque a autora examinou a aplicação do modelo ecológico para situações de abuso de crianças e adolescentes em sentido amplo e, "na medida em que o foco de avaliação nos casos de abuso ou negligência é sobre a relação entre os pais e a criança e outros relacionamentos familiares, torna-se importante entender as influências destas outras variáveis dos sistemas, para as finalidades de intervenção" (p. 47).

${ }^{542}$ A CIDC, aprovada em 1989, consagrou a Doutrina da Proteção Integral dos direitos da criança na legislação internacional. No Brasil, um marco histórico da mudança de paradigma no Direito da Criança e do Adolescente ocorreu, inicialmente, com a promulgação da Constituição de 1988, que consagrou o capítulo VII (inserido no Título VIII - Da ordem social) à proteção "da família, da criança, do adolescente e do idoso", e assumidamente adotou a Doutrina da Proteção Integral no artigo 227, que estabelece direitos e garantias das crianças e adolescentes. Logo após, em 1990, o Brasil se torna referência mundial por ser um dos primeiros países a incorporar a Doutrina da Proteção Integral na lei - o ECA. O ECA considera as crianças e os adolescentes como sujeitos de direitos (e, no caso dos adolescentes, também de responsabilidades) e garante a eles todos os direitos da pessoa humana e o direito à proteção integral por estarem em desenvolvimento, assegurando, por Lei, todas as oportunidades e facilidades para que eles possam desenvolver-se física, mental, moral, espiritual e socialmente, com liberdade e dignidade (artigo $3^{\circ}$ da Lei 8069/90). Estabelece a prioridade absoluta às crianças e aos adolescentes na garantia e no atendimento de todos os direitos, bem como a co-responsabilidade, solidária, entre família, Estado e sociedade na garantia desses direitos.

${ }^{543}$ BRASIL. Presidência da República. Secretaria de Direitos Humanos. Conselho Nacional dos Direitos da Criança e do Adolescente. Resolução 113, 19 de abril de 2006: Dispõe sobre os parâmetros para a institucionalização e fortalecimento do Sistema de Garantia dos Direitos da Criança e do Adolescente. Disponível http://www.fundocrianca.org.br/forum/arquivos/RESOLUÇÃO\%20N%20113\%20CONANDA.pdf Consulta 06.08.2010. 
Conforme a mesma Resolução, o SGD "articular-se-á com todos os sistemas nacionais de operacionalização de políticas públicas, especialmente nas áreas da saúde, educação, assistência social, trabalho, segurança pública, planejamento, orçamentária, relações exteriores e promoção da igualdade e valorização da diversidade. (art. $\left.1^{\circ}, \S^{\circ}\right)$."

Inspirado mais pelos termos da CIDC do que, propriamente, pelo ECA, que não estabeleceu de maneira clara um sistema de garantia de direitos, segundo NOGUEIRA NETO, "o SGD se operacionaliza mais como um "sistema estratégico" do que propriamente um "sistema de atendimento direto". Essa natureza "estratégica" é própria, aliás, do sistema de promoção e proteção dos direitos humanos em geral, do qual ele é parte. (...) As ações das instâncias públicas governamentais e não-governamentais, que integram esse sistema, precisam ser alavancadoras e facilitadoras, visando uma inclusão privilegiada e monitorada desse público [crianças e adolescentes] (...) nos serviços e programas dos órgãos da administração pública" ${ }^{\text {"44 }}$.

A partir da formulação de NOGUEIRA NETO, identifica-se que o SGD opera não só a partir de uma abordagem "ascendente e descendente", mas também de forma horizontal, interna e externamente. Articulado em três eixos principais (funções estratégicas de promoção, defesa e controle), os atores do SGD desempenham primordialmente funções de uma linha estratégica (podendo desempenhar, subsidiariamente, funções de outra), ao mesmo tempo em que se articulam, horizontalmente e verticalmente, com os demais atores. E o próprio SGD somente pode atingir seus objetivos a partir da articulação com outros sistemas que promovem atendimento direto, tais como o SUS (Sistema Único de Saúde) e o SUAS (Sistema Único de assistência social).

Especificamente no que toca à abordagem ascendente que informa o SGD, ela se verifica, na prática, em diversas oportunidades de participação da sociedade civil, incluindo crianças e adolescentes, na formulação de programas e planos de trabalho.

Algumas dessas formas de participação foram mencionadas no Capítulo 3, item 3.3. tais como: as Conferências de Direitos da Criança e do Adolescente, convocadas pelo

\footnotetext{
${ }^{544}$ NOGUEIRA NETO, Wanderlino. Por um sistema de promoção e proteção dos direitos humanos de crianças e adolescentes. Revista Serviço Social e Sociedade, ano XXVI, n. 83, Edição Especial Criança e Adolescente, p.5-29. São Paulo: Cortez, 2005
} 
Conanda e organizadas pelos Conselhos de Direitos em nível municipal, estadual e federal, com a participação, de crianças e adolescentes, por meio das chamadas Conferências Lúdicas, a partir de 1999, primeiro como observadores, a partir de 2003, como delegados, e, a partir de 2011-2012, como organizadores, são exemplos da aproximação "ascendente e descendente" adotada pelo SGD. Outros exemplos são a participação de adolescentes no chamado "Orçamento Criança e Adolescente - OCA", e, mais recentemente, a Política Nacional dos Direitos Humanos de Crianças e Adolescentes $^{545}$ proposta pelo Conanda para o próximo decênio (Plano Decenal).

O modelo de ecologia social (IICRD) ou modelo ecológico de desenvolvimento (LIDCHI), portanto, é um parâmetro internacionalmente utilizado para a promoção de desenvolvimento humano que, conforme as formulações acima apresentadas, é plenamente compatível com o sistema brasileiro.

A figura ${ }^{546}$ abaixo sintetiza o Modelo da Ecologia Social dos Direitos da Criança do IICRD e permite visualizar os atores que compõem o que, no Brasil, é chamado de Sistema de Garantia de Direitos:

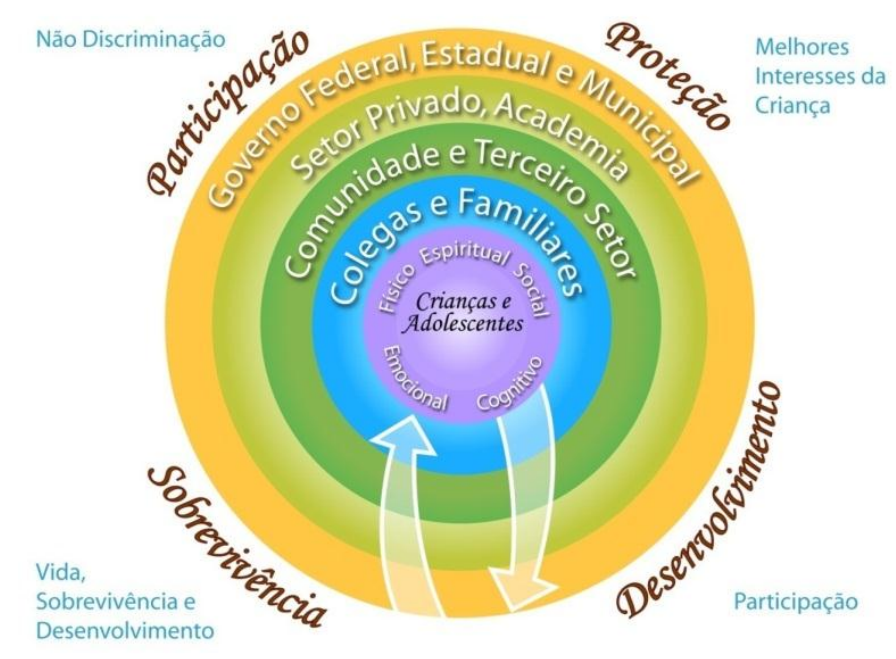

Conforme o documento "Série de Manuais do Círculo dos Direitos", "o uso da Ecologia Social dos Direitos da Criança e do Adolescente (...) ajuda a identificar os bens,

\footnotetext{
${ }^{545}$ BRASIL. Presidência da República. Secretaria de Direitos Humanos. Secretaria Nacional de Promoção dos Direitos da Criança e do Adolescente. Conselho Nacional dos Direitos da Criança e do Adolescente. Construindo a Política Nacional dos Direitos Humanos de Crianças e Adolescentes e o Plano Decenal dos Direitos Humanos de Crianças e Adolescentes 2011 - 2020...

${ }^{546}$ CURRIE, op cit. $\mathrm{p}, 17$.
} 
capacidades e oportunidades para a criança e o adolescente, em seus sistemas de apoio e no contexto social e cultural que as apoia e protege (...). O modelo da Ecologia Social dos Direitos da Criança e do Adolescente leva em consideração a CRC [CIDC] e os pontos fortes e as lacunas no sistema de proteção, e nos ajuda a informar o contexto da criança e do adolescente, identificando os pontos fortes e os desafios em suas vidas" ${ }^{\text {547 }}$.

O Modelo da Ecologia Social dos Direitos da Criança e do Adolescente do IICRD afina-se com os termos desenvolvidos na presente pesquisa, uma vez que enfatiza a participação de crianças e adolescentes na identificação de fatores de risco e fatores de proteção, e na criação de estratégias para a promoção da superação dos desafios para sua proteção. Ademais, apesar de estar sendo desenvolvido desde 1994, com base na ferramenta "Triplo A" do Unicef (Avaliação, Análise e Ação), a primeira publicação que sistematizou a metodologia incorporando um foco mais forte na mudança sistêmica baseada em direitos de modo "ascendente", em quatro fases, foi a Série de Manuais do Círculo dos Direitos do Programa $\mathrm{CPP}^{548}$ (programa este que tem como foco, exatamente, o enfrentamento da violência sexual contra crianças e adolescentes facilitada pela TIC).

É importante deixar claro que, de modo algum, o modelo participativo proposto pelo IICRD coloca nas mãos de crianças e adolescentes a responsabilidade exclusiva pela própria proteção. Embora já tenha sido enfatizado ao longo deste trabalho repetidas vezes, não é demais lembrar que o reconhecimento de crianças e adolescentes como sujeitos de direitos e, portanto, como capazes de se manifestar, identificar riscos e (re)agir para sua própria proteção não significa e nem autoriza a desresponsabilização de adultos, ou seja, de todos os demais atores do SGD, de seu papel fundamental na promoção, defesa e controle $^{549}$ de direitos de crianças e adolescentes.

\footnotetext{
${ }^{547}$ CURRIE, op cit., p. 17.

${ }^{548}$ O Círculo dos Direitos é um processo de pesquisa-ação e de planejamento intencional, centrado na criança e no adolescente, que apoia a inovação social e uma responsabilidade maior para crianças, adolescentes, jovens e suas famílias. Esta metodologia reflexiva e dirigida a ações, que parte das perspectivas das próprias crianças, ajuda atores sociais comunitários, agências governamentais e responsáveis pela elaboração de políticas a desenvolver políticas, programas e sistemas de monitoramento integrados, construindo a partir dos pontos fortes locais para enfrentar os desafios enfrentados pelas crianças e adolescentes, seus pares, suas famílias e comunidades. O processo do Círculo dos Direitos parte, de forma singular, das realidades vividas pelas crianças e adolescentes, buscando mudança sistêmica e sustentável para a promoção de uma maior dignidade, senso de pertencimento e justiça para crianças, adolescentes e jovens e para o nosso mundo" CURRIE, op cit. p. 18.

${ }^{549}$ A formulação do SGD a partir dos eixos estratégicos Promoção, Defesa e Controle da Efetivação se deve, salvo melhor juízo, a Wanderlino NOGUEIRA NETO (Cf., para mais detalhes, NOGUEIRA NETO, op cit.)
} 
A metodologia Círculo dos Direitos constrói a partir do Modelo da Ecologia Social propondo um trabalho em quatro fases ${ }^{550}$, que resultam em planos de ação construídos a partir das realidades de vida de crianças e adolescentes mas que não serão, necessariamente, executados por elas.

Podem-se identificar, como resultados, planos de ação em, pelo menos, três níveis:

- planos elaborados e executados pelas crianças e adolescentes e que necessitam apoio e supervisão de adultos (exemplo: ações de conscientização dos amigos e colegas a respeito de medidas de prevenção durante a navegação na internet; conversas com familiares a respeito de medidas de prevenção durante a navegação na internet);

- planos de ação identificados a partir das realidades das crianças e adolescentes e executados por adultos mas incluindo a participação de crianças e adolescentes ao longo de todo o processo (exemplos: desenvolvimento de um jogo on-line para prevenção, cuja ideia partiu de conversas entre adultos e crianças e adolescentes sobre formatos educativos amigáveis para prevenção; o jogo foi desenvolvido por adultos e "pilotado" - testado - com crianças e adolescentes que já participavam do programa CPP e com grupos de controle de crianças não

Na formulação da Política Nacional dos Direitos Humanos de Crianças e Adolescentes proposta pelo Conanda para o próximo decênio (Plano Decenal), esses eixos foram reformulados, e dois novos acrescentados: 1. Promoção dos Direitos; 2. Proteção e Defesa dos Direitos; 3. Participação de Crianças e Adolescentes; 4. Controle Social da Efetivação dos Direitos; 5. Gestão da Política. (BRASIL. Presidência da República. Secretaria de Direitos Humanos. Secretaria Nacional de Promoção dos Direitos da Criança e do Adolescente. Conselho Nacional dos Direitos da Criança e do Adolescente. Construindo a Política Nacional dos Direitos Humanos de Crianças e Adolescentes e o Plano Decenal dos Direitos Humanos de Crianças e Adolescentes 2011 - 2020...; p 21-230.Cf. item 3.3. deste trabalho.

550 "Fase 1: Mapeamento: Mapeia o contexto de direitos e de proteção das crianças e adolescentes no nível de mandato (leis e políticas) e de mecanismo (programas, parceiros e serviços), desde o nível nacional ao comunitário ; Mapeia os atores sociais envolvidos nas vidas das populações-alvo e nas dos seus parceiros.

Fase 2: Engajamento: Desenvolve compreensão básica (ponto de partida) sobre as experiências vividas pelas crianças e adolescentes; Desenvolve compreensão aprofundada dos pontos fortes, desafios, fatores de risco e mecanismos de proteção centrados na criança e no adolescente, para apoiá-los e protegê-los a partir de suas próprias perspectivas, de suas famílias e comunidades.

Fase 3: Planejamento: Analisa coletivamente os pontos fortes, riscos, lacunas e oportunidades; Identifica as raízes dos problemas e as estratégias para enfrentar os desafios e as lacunas; Desenvolve planos de ação e de políticas comunitárias centrados na criança e no adolescente, culturalmente embasados e centrados em direitos.

Fase 4: Criação: Realiza análise intersetorial do Círculo dos Direitos; Cria planos de ação intersetoriais integrados, focados em estratégias centradas na criança e no adolescente, na parceria, na capacitação, em programas e em reformas das leis e das políticas; Cria modelos de monitoramento e avaliação, e estratégias de sustentabilidade e responsabilidade, incluindo mudanças organizacionais, reforma de direitos e engajamento comunitário." CURRIE, op cit, p. 19. 
participantes, oriundas de diferentes realidades culturais, sociais e econômicas; realização de reuniões comunitárias a respeito da prevenção de violência sexual mediada pela TIC no centro comunitário local, organizado por atores sociais locais, como pais, professores, donos de lanhouse e com a participação das crianças e adolescentes);

- planos de ação de "alto nível", identificados a partir das realidades de crianças e adolescentes e executados por adultos em nível institucional elou de política pública, preferencialmente de forma intersetorial, que podem ou não incluir a participação de crianças e adolescentes em uma ou mais fases do processo (exemplo: após identificar, com crianças e adolescentes da periferia de São Paulo e Santo André, e de cidades do Maranhão, que não sentiam confiabilidade na Polícia pra reportar situações de violência ou ameaça de violência on-line - e mesmo de situações de violência reais -, a Polícia Militar do Estado de São Paulo, que tem entre suas atribuições o policiamento comunitário e policiamento escolar, incluiu no currículo da formação de soldados um conteúdo a respeito da violência sexual mediada pela TIC, com o intuito de preparar futuros policiais militares para orientação de crianças e adolescentes a respeito da prevenção) ${ }^{551}$.

A metodologia, portanto, propõe o engajamento de atores do SGD em todos os momentos do processo, fomentando trocas e diálogos ativos para alcançar objetivos de modo sistemático e progressivo ${ }^{552}$.

${ }^{551}$ Exemplos retirados de CURRIE, Vanessa. Relatório do Círculo dos Direitos - CPP Brasil: Exploração Sexual Infantojuvenil facilitada pela TIC: uma Análise a Partir das Realidades Vividas de Crianças e Adolescentes. Tradução: Viviane Fontoura; Coordenação e Revisão Técnica da edição brasileira: Maria Emilia Accioli Nobre Bretan. Victoria/BC: International Institute for Child Rights and Development, 2011 (no prelo; versão $\quad$ em $\quad$ inglês $\quad$ disponível http://childprotectionpartnership.org/resources/recommended/child-led-solutions/exploring-ict-enabledchild-sexual-exploitation-through-li); p. 15-16; p.54-59.

552 “Os resultados específicos do Círculo dos Direitos incluem (...): Um grupo de crianças, adolescentes, jovens e membros de comunidades engajado e informado, trabalhando em conjunto para alcançar mudanças positivas.

Fatores de risco e mecanismos de proteção são identificados, apoiando planejamento, elaboração de orçamentos e programação eficientes, para a sobrevivência, desenvolvimento, proteção e participação de crianças e adolescentes.

Criação e implementação de planos de ação local sustentáveis; sociedade civil e governo trabalham juntos para resolver os problemas identificados por eles.

Parcerias estratégicas são fortalecidas e focadas em preencher as lacunas existentes nos direitos. 
Outra vantagem de trabalhar junto com/a partir das realidades de crianças e adolescentes é poder desenvolver estratégias adequadas para cada faixa etária e realidade social/econômica/cultural.

No exemplo do jogo on-line, acima referido, ao questionarem-se as crianças e adolescentes a respeito de como deveria ser, foram categóricas ao indicar que os jogos deveriam ser diferentes para crianças e adolescentes, tendo apontado, até mesmo, as faixas etárias para cada tipo de jogo. Indicaram, por exemplo, que para atrair a atração de adolescentes, o jogo deveria ser em 3D. Essas sugestões foram determinantes para as decisões tomadas no momento do design instrucional do jogo, das temáticas que seriam abordadas e da maneira como seriam abordadas.

Por ter sido "pilotado" com crianças de diferentes realidades culturais, sociais e econômicas, também foi possível identificar questões importantes. Um exemplo: tematizado como "Galáxia da Internet" avatares (personagens) para os jogadores escolherem: dois avatares sem sexo ("ETs") e dois humanos (um homem e uma mulher), que podiam ser customizados. Durante a pilotagem do jogo no Maranhão, uma criança, de cor negra, reclamou da falta de opção de avatares negros no jogo. Ela não se identificava com a pequena astronauta branca, tampouco com os "ETs".

Por fim, engajar ativamente crianças e adolescentes na identificação de desafios e na busca de soluções parece ser uma estratégia eficaz para obter mudança de comportamento - que é o desejado quando se pretende realizar prevenção. Campanhas publicitárias de prevenção conseguem atingir uma parcela do público; cartilhas de conscientização ${ }^{554}$,

Sistemas de fornecimento de serviços são desenvolvidos com estruturas de responsabilidade baseadas nas comunidades, para garantir o sucesso contínuo e a sustentabilidade.

As realidades comunitária e cultural são integradas na programação, nos serviços e nas políticas para crianças e adolescentes.

Processos colaborativos de planejamento, monitoramento e avaliação multissetoriais são desenvolvidos". CURRIE, V. Série de Manuais...,p. 20.

Grupos de diferentes setores colaboram para implementar e monitorar os direitos de crianças e adolescentes.

${ }^{553} \mathrm{O}$ jogo pode ser visualizado em http://www.galaxiainternet.org.br/2011/. As informações aqui fornecidas a respeito do processo de design do jogo constam de relatórios internos do Programa CPP; os documentos são de uso interno, porém não confidencial.

${ }^{554}$ Alguns exemplos de materiais de prevenção são as cartilhas da Safernet e da Childhood Brasil, ambas disponíveis on-line. SaferNet Brasil. Cartilha Saferdic@as. Disponível em http://www.safernet.org.br/site/sites/default/files/cartilha-site.pdf. Download em 23/12/2010; VASCONCELOS, Ana Maria Pinheiro (redação); IACOCCA, Michele (ilustração). Navegar com 
mesmo quando em linguagem mais "jovem”, não atraem o público adolescente. Isso não significa que esses materiais não devam ser utilizados, mas sim que não "falam" a linguagem de todos os públicos - crianças e adolescentes.

Lembrando que a participação é característica fundamental do desenvolvimento de crianças e adolescentes, envolvê-las no processo parece ser a melhor forma de obter engajamento e mudança de comportamento.

\subsubsection{Fatores de risco (vulnerabilidade) e fatores de proteção}

A abordagem preventiva baseada no modelo da ecologia social, em ambas as formulações acima apresentadas, busca identificar fatores de risco/vulnerabilidade e fatores de proteção que aumentam ou diminuem o risco de violação de direitos de crianças e adolescentes.

A identificação de pontos fortes/fatores de proteção e de pontos fracos/fatores de risco/vulnerabilidade é feita, usando a abordagem ecológica, em cada um dos sistemas que envolvem a criança/adolescente e, ainda, em nível individual.

LIDCH identifica quatro níveis de análise: individual, das relações, da comunidade e da sociedade. Alguns exemplos de fatores de risco e proteção relacionados a abuso e negligência de crianças e adolescentes identificados nesses quatro níveis são ${ }^{555}$ :

\begin{tabular}{|c|l|l|l|}
\hline Nível & \multicolumn{2}{|c|}{ Fatores de Risco } & \multicolumn{2}{c|}{ Fatores de Proteção } \\
\hline \multirow{5}{*}{ Individual } & Fatores de vulnerabilidade dos & Apego seguro do bebê com o \\
& pais (doença física ou mental; uso & adulto que o cuida; boas auto- \\
& de drogas ou abuso de álcool; & dificuldade de apego emocional & estima e capacidade intelectual \\
& na família); fatores de & cuidador; habilidade de \\
& vulnerabilidade para a criança & avaliar situações de risco para a \\
& criança/adolescente e de protegê- \\
& (ser um bebê não desejado; ter & los em situação de violência. \\
\hline
\end{tabular}

segurança: protegendo seus filhos da pedofilia e da pornografia infanto-juvenil na Internet. São Paulo: CENPEC, 2006. Disponível em: http://www.childhood.org.br/wp-content/uploads/2008/11/Navegar-comSegurança-2008-1.pdf. Estas duas instituições já realizaram campanhas de prevenção na internet (usando "virais" - cf Glossário, viral) e na televisão (Cf site http://www.safernet.org.br/site/prevencao).

${ }^{555}$ A tabela é exemplificativa, e seu conteúdo foi baseado no artigo de LIDCHI, referenciado. 


\begin{tabular}{|c|c|c|}
\hline & $\begin{array}{l}\text { necessidades } \\
\text { temperamento percebido como } \\
\text { "difícil"). }\end{array}$ & \\
\hline Relações & $\begin{array}{l}\text { Condições de moradia } \\
\text { inadequadas; violência entre pais } \\
\text { e filhos, discriminação } \\
\text { étnica/cultural; ausência de rede } \\
\text { de apoio em situações difíceis. }\end{array}$ & $\begin{array}{l}\text { Apoio entre membros da família; } \\
\text { limites claros; rotinas pré- } \\
\text { estabelecidas e de fácil } \\
\text { compreensão; habilidade em } \\
\text { resolver problemas de forma } \\
\text { amigável. }\end{array}$ \\
\hline Comunidade & $\begin{array}{l}\text { Tolerância de violência e } \\
\text { desigualdade sociais; alto índice } \\
\text { de desemprego; pobreza; tráfico } \\
\text { de drogas; falta de políticas } \\
\text { públicas. }\end{array}$ & $\begin{array}{l}\text { Acesso a serviços de apoio } \\
\text { comunitário; } \\
\text { orientados a famílias vulneráveis; } \\
\text { iniciativas locais contra maus- } \\
\text { tratos a crianças; família } \\
\text { estendida morando perto. }\end{array}$ \\
\hline Sociedade & $\begin{array}{l}\text { Falta de políticas } \\
\text { socioeconômicas, de saúde e } \\
\text { educação; norma social e cultural } \\
\text { que glorifica a violência; falta de } \\
\text { colaboração entre setores para um } \\
\text { sistema de prevenção. }\end{array}$ & $\begin{array}{l}\text { Legislação eficaz de proteção à } \\
\text { criança; capacitação e criação de } \\
\text { empregos; campanhas sobre os } \\
\text { direitos humanos e de divulgação } \\
\text { do ECA. }\end{array}$ \\
\hline
\end{tabular}

Tabela elaborada a partir do conteúdo de LIDCH, op. cit., p. 48-50.

A metodologia do Círculo dos Direitos, do mesmo modo, apresenta uma série de atividades que buscam identificar pontos fortes e desafios desde o nível macro (identificação de pontos fortes e lacunas referentes a leis, políticas, programas, parceiros e serviços, desde o nível nacional ao comunitário); passando pelo mapeamento dos atores sociais comunitários diretamente envolvidos nas vidas das crianças/adolescentes; investiga as condições de vida de crianças e adolescentes envolvidas no processo (mundo interior e mundo exterior) a partir do ponto de vista delas e, no caso específico da CPP, identifica suas práticas no uso da TIC e fatores de risco e proteção on-line e off-line.

Com isso, é possível ter uma "compreensão aprofundada dos pontos fortes, desafios, fatores de risco e mecanismos de proteção centrados na criança e no adolescente, 
para apoiá-los e protegê-los a partir de suas próprias perspectivas, de suas famílias e comunidades" ${ }^{, 556}$.

Aplicando a abordagem da ecologia social para programas de prevenção, em outro artigo, LIDCHI também aponta a necessidade de ouvir crianças e adolescentes na elaboração de programas eficientes e eficazes. A autora refere ter acompanhando um programa de prevenção na Inglaterra para ensinar autoproteção que não funcionava porque "os autores não tinham experiências com crianças, nunca tinham falado com crianças e não conheciam os conceitos da criança sobre perigo. Estavam então utilizando conceitos adultos sobre o perigo para informar crianças e, assim sendo, o programa de prevenção, no final, não funcionou ${ }^{557 \%}$.

Nota-se, contudo, que a identificação de fatores de risco/vulnerabilidade e fatores de proteção para o desenvolvimento de estratégias de prevenção eficazes, seja qual for a abordagem de ecologia social utilizada, nunca é feito somente a partir da perspectiva das crianças e adolescentes; ao contrário, sempre inclui a participação de outros atores do SGD, como as famílias e, na perspectiva adotada pelo IICRD, incluindo também outros atores do SGD até o nível nacional.

Na pesquisa-ação piloto do Círculo dos Direitos, realizada em São Paulo, Santo André e Maranhão, por exemplo, foram identificados por crianças, adolescentes e adultos, diversos fatores de risco(vulnerabilidade)/proteção, especificamente relacionados à violência sexual contra crianças e adolescentes facilitada pela $\mathrm{TIC}^{558}$. Alguns deles são:

\begin{tabular}{|c|c|c|}
\hline Nível & $\begin{array}{c}\text { Fatores de } \\
\text { Risco/vulnerabilidades }\end{array}$ & Fatores de Proteção \\
\hline Mundo & - $\quad$ Dificuldade de ser ouvido & - $\quad$ Sentimento $\mathrm{de}$ \\
\hline
\end{tabular}

${ }^{556}$ CURRIE, Série de Manuais..., p. 19.

${ }^{557}$ LIDCHI, Victoria. Panorama Internacional e a posição do Brasil no enfrentamento e prevenção do abuso sexual infantil. In WILLIAMS, Lúcia Cavalcanti de Albuquerque. (Org.); ARAUJO, Eliane A C (Org.) Prevenção do abuso sexual infantil: um enfoque interdisciplinar. Curitiba: Juruá, 2009; p. 41-56; p. 46.

${ }^{558}$ A tabela apresentada é exemplificativa e inclui resultados de oficinas desenvolvidas em três locais diferentes (São Paulo, Santo André e São Luís e outros municípios do Maranhão); ao ser implementado com outros grupos, os fatores de risco/proteção variarão com o local e os participantes envolvidos. Anoto que o escopo do Programa CPP era maior do que o objeto de estudo desta pesquisa, pois teve como um de seus focos a discussão da responsabilização de atores envolvidos na (com a ) violência sexual facilitada pela TIC, incluindo o fortalecimento de polícias para a investigação de crimes on-line. No mesmo sentido, o próprio conceito de violência sexual facilitada pela TIC adotado no projeto tem o escopo maior, abrangendo a pornografia infantil, o turismo sexual etc. 


\begin{tabular}{|c|c|c|}
\hline $\begin{array}{c}\text { interior/exterior da } \\
\text { criança }\end{array}$ & $\begin{array}{l}\text { pela família; } \\
\text { - Violência doméstica; } \\
\text { - } \quad \text { Abuso sexual intrafamiliar; } \\
\text { - Necessidade de trabalhar } \\
\text { para poder ajudar a família }\end{array}$ & $\begin{array}{l}\text { importante para a família; } \\
\text { - Sentimento de autoestima e } \\
\text { de ser corajoso; } \\
\text { - Família como local de } \\
\text { apoio, proteção e cuidado. }\end{array}$ \\
\hline Uso da TIC & $\begin{array}{l}\text { - Acesso da internet na lan } \\
\text { houses com instalações precárias } \\
\text { e inseguras para crianças; } \\
\text { - Iletramento digital e falta de } \\
\text { interesse da família; } \\
\text { - Falta de conversa com os } \\
\text { amigos sobre os riscos da } \\
\text { internet; } \\
\text { - Risco potencial de vício em } \\
\text { jogos; } \\
\text { - Uso de jogos violentos; } \\
\text { - Uso da lanhouse sem } \\
\text { supervisão/ciência dos pais em } \\
\text { horário noturno (Corujão); } \\
\text { - Falta } \\
\text { supervisão/orientação } \\
\text { lanhouse e de bloqueio de sites } \\
\text { inadequados; } \\
\text { - Lanhouse como ponto de } \\
\text { drogas; } \\
\text { - Exposição a conteúdo sexual } \\
\text { on-line e risco de abordagens por } \\
\text { estranhos on e off-line. }\end{array}$ & $\begin{array}{l}\text { - Acesso à internet e oficinas } \\
\text { de TI nas ONGs; } \\
\text { - Lanhouse como local de } \\
\text { socialização importante; } \\
\text { - Redes sociais como } \\
\text { importantes para conectar-se } \\
\text { com os amigos; } \\
\text { - Centralidade da TIC na vida } \\
\text { das crianças e adolescentes; } \\
\text { - Uso da TIC para se } \\
\text { comunicar com familiares e para } \\
\text { pedir ajuda quando necessário; } \\
\text { Uso da internet para } \\
\text { pesquisa e trabalhos da escola, } \\
\text { para ajudar familiares a fazer } \\
\text { currículo; }\end{array}$ \\
\hline Comunidade & $\begin{array}{l}\text { - Precariedade de infra- } \\
\text { estrutura básica (saneamento, } \\
\text { água, luz, urbanismo); } \\
\text { - Falta de serviços sociais; } \\
\text { - Criminalidade (tráfico de } \\
\text { drogas e violência); } \\
\text { - Insegurança; } \\
\text { - Escassez de locais de lazer; } \\
\text { - Escolas mal cuidadas, } \\
\text { inseguras ou distantes dos locais } \\
\text { de moradia; } \\
\text { - Renda mensal baixa; } \\
\text { - Falta de policiamento/pouca } \\
\text { confiança na polícia } \\
\end{array}$ & $\begin{array}{l}\text { - Centros comunitários e e } \\
\text { ONGs de proteção à criança com } \\
\text { serviços e atividades em horário } \\
\text { complementar à escola; } \\
\text { - Desenvolvimento } \\
\text { economia local informal; } \\
\text { - Trabalho de conscientização } \\
\text { e transformação para tratar das } \\
\text { questões relacionadas com a } \\
\text { violência e com a falta de coesão } \\
\text { social na comunidade; } \\
\text { - Escolas e outros locais na } \\
\text { comunidade identificados como } \\
\text { seguros (igreja). }\end{array}$ \\
\hline $\begin{array}{c}\text { Sistema Nacional de } \\
\text { Proteção de } \\
\text { Crianças/adolescentes } \\
\text { em relação à TIC }\end{array}$ & $\begin{array}{l}\text { - Fraca capacidade de } \\
\text { aplicação/cumprimento das leis } \\
\text { (law enforcement); } \\
\text { - Escassez de dados e } \\
\text { estatísticas nacionais sobre os } \\
\text { diversos fenômenos por detrás da } \\
\text { violência sexual; } \\
\text { - Falta de coordenação entre } \\
\text { os serviços de denúncia de abuso } \\
\text { sexual e os provedores de } \\
\text { serviços responsáveis pelas } \\
\text { investigações criminais; } \\
\text { "Sistema de Justiça } \\
\text { "adultocêntrico" e não } \\
\text { necessariamente amigável para } \\
\text { crianças e adolescentes; }\end{array}$ & $\begin{array}{l}\text { - Disposição governamental } \\
\text { para o enfrentamento da } \\
\text { exploração sexual infantojuvenil } \\
\text { e inclusão na agenda política; } \\
\text { - Arcabouço jurídico forte } \\
\text { (ECA, Código Penal e CF88); } \\
\text { - Sociedade civil e governo } \\
\text { organizados de forma } \\
\text { interdisciplinar (Comitês } \\
\text { intersetoriais em nível nacional, } \\
\text { CPIs no Congresso Nacional); } \\
\text { - SGD amplo e complexo; } \\
\text { - Conselhos de Direitos da } \\
\text { Criança em } 3 \text { níveis; } \\
\text { - Planos nacionais e políticas } \\
\text { intersetoriais estabelecidas em }\end{array}$ \\
\hline
\end{tabular}




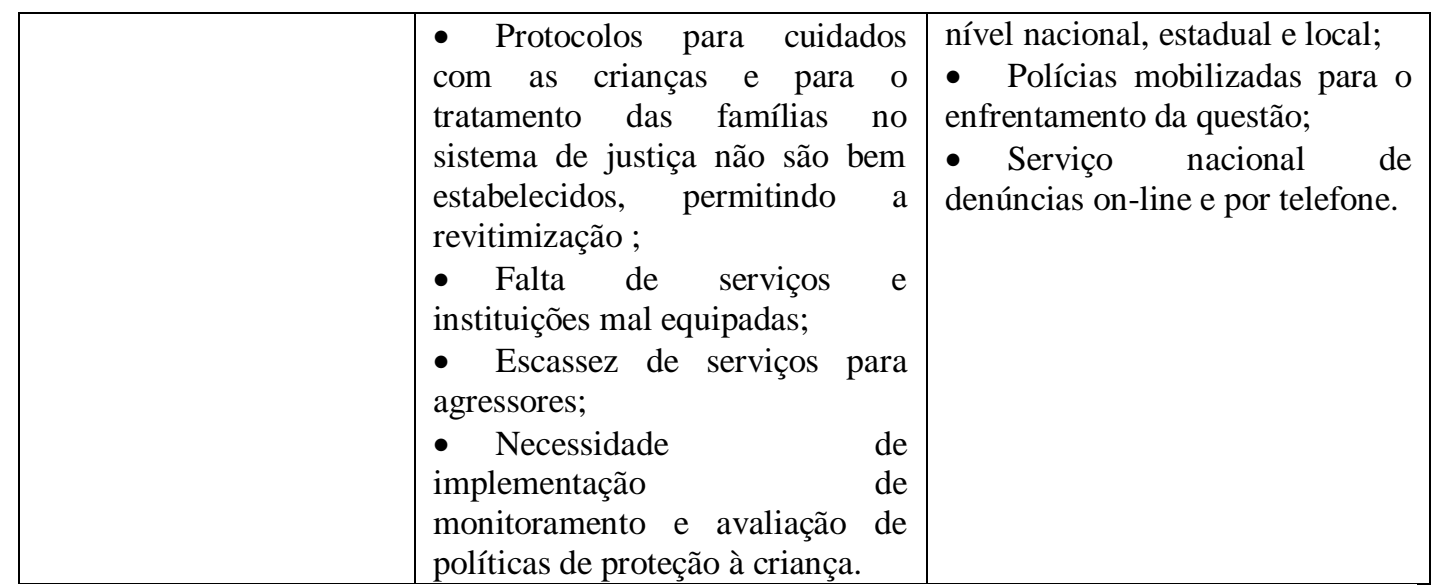

Tabela elaborada a partir do conteúdo de CURRIE, Vanessa. Relatório do Círculo dos Direitos... p. 29-51.

Esclareça-se que, na implementação piloto da metodologia, o item Sistema Nacional de Proteção de Crianças/adolescentes em relação à TIC foi mapeado somente com adultos, atores do SGD em diversos níveis; o item Comunidade foi mapeado por adultos e crianças; já os itens Uso da TIC e Mundo Interior/Exterior da Criança foram mapeados somente por crianças e adolescentes por meio de oficinas e atividades facilitadas por adultos e, posteriormente, sistematizadas.

Isso possibilita que estratégias sejam desenvolvidas tanto em nível micro, lideradas por crianças e adolescentes e executadas por elas; quanto em nível macro, envolvendo atores do SGD em diversos níveis. Um ponto importante, porém, foi a clara verificação de que o ponto de vista das crianças e adolescentes, muitas vezes, era desconhecido pelos $\operatorname{adultos}^{559}$, o que dialoga com a afirmação de LIDCHI, acima, de que programas podem ser executados por adultos sem o conhecimento da realidade da criança mas com alto risco de serem ineficazes.

Ao examinar os conteúdos mapeados, é possível identificar que há fatores que representam, ao mesmo tempo, risco e proteção. Na metodologia do Círculo dos Direitos, estes são pontos críticos escolhidos para a elaboração de planos de ação. Isso explica, por

\footnotetext{
${ }^{559}$ A surpresa com as diferenças entre pontos de vista de crianças e adolescentes e adultos sobre fatores de risco e de proteção foi manifestada diversas vezes durante oficinas do Círculo dos Direitos realizadas em diversos locais, por membros das ONGs participantes. Uma das participantes relatou que se deu conta que, durante uma das atividades de mapeamento comunitário, estava tentando (sem perceber) guiar o olhar das crianças e adolescentes; posteriormente, verificou o quanto havia sido importante se distanciar, pois os resultados realmente haviam sido muito diferentes do que esperava.
} 
exemplo, que crianças e adolescentes tenham elegido a conscientização dos donos de lanhouses como foco de seu plano de ação (as ações foram executadas envolvendo uma rede considerável de parceiros em um município do Maranhão); do mesmo modo, o plano de conscientizar os amigos por meio de jogos surgiu em uma das reuniões feitas em São Paulo e derivou para a criação de um jogo on-line, ideia que foi "abraçada" pelos adultos, e desenvolvida com a participação das crianças e adolescentes.

A escolha de fatores que representam ao mesmo tempo risco e proteção é estratégica e extremamente eficaz. Ao analisar os aspectos do desenvolvimento de crianças e adolescentes, nos capítulos anteriores, especialmente quando se levam em conta, por exemplo, as formas de socialização de crianças e adolescentes e as atividades que são atraentes em cada momento de suas vidas.

Por exemplo, o gosto por estar em grupos, a necessidade de autoafirmação, que são apontados na literatura como característicos da adolescência, e que se manifestam negativamente, por exemplo, na cultura da vaidade e na prática de atos como bullying e cyberbullying, também se manifesta positivamente nas práticas de socialização on-line, na identificação de líderes entre os adolescentes; esses aspectos positivos podem ser aproveitados, também, para a identificação de estratégias que tirem proveito desses pontos positivos (ex: formação de comunidades on-line para tirar dúvidas sobre navegação segura, criação de competições e jogos ligados à prevenção e a outras questões relacionadas, como respeito/autorrespeito).

O resultado do processo-piloto aplicado no Programa CPP foi claramente empoderador para as crianças e adolescentes. Ao se envolverem ativamente na realização de "ações diretas em suas comunidades (...) crianças e adolescentes mostraram-se entusiasmadas quanto à oportunidade de criar soluções para algumas questões que elas haviam levantado em suas comunidades. Elas também expressaram que se sentiram valorizadas e ouvidas, e que estavam ansiosas para trabalhar com parceiros adultos em seus Planos de Ação.

"Meus pais vão ficar orgulhosos de mim!” (Criança, Maranhão)

(...) 
“(...) eu nunca imaginei que um dia eu pudesse ir à Assembléia Legislativa, muito menos conversar com deputados." (Menino, 15 anos, Maranhão) ${ }^{560}$

O Modelo da Ecologia Social, na formulação do IICRD (metodologia do Círculo dos Direitos) dialoga, claramente, com elementos coletados neste trabalho como:

(i) os direitos à participação e ao desenvolvimento (ao promover a participação de crianças de diversas idades participem do processo; ao identificar riscos/vulnerabilidades a partir das vivências das crianças no processo com a participação delas; ao identificar soluções que atendam às suas condições peculiares de pessoas em desenvolvimento desenvolvimento de jogo de prevenção em linguagem amigável etc; Caps. 3 e 4);

(ii) os dados disponíveis a respeito do uso que crianças e adolescentes fazem da TIC (riscos e vulnerabilidades identificados estão retratados nas pesquisas, como o autodidatismo na aprendizagem da tecnologia ou aprendizagem com amigos, uso da internet em lan-houses e/ou uso pouco supervisionado em casa; a centralidade da TIC na vida de crianças e adolescentes etc; Capítulo 2);

(iii) as novas formas de sociabilidade, a centralidade da TIC na vida de crianças e adolescentes (Capítulo 1), que apontam para a necessidade de promover estratégias de prevenção e que indicam que estas estratégias podem e devem fazer uso dos aspectos positivos da própria tecnologia, como o uso de jogos eletrônicos educativos, a criação de canais de orientação on-line, a promoção de fóruns participativos on-line para troca de informações sobre uso seguro de tecnologia etc;

(iv) as pesquisas de vitimização e a dinâmica da violência sexual mediada pela TIC, que a) deixam claro que a violência sexual mediada pela TIC pode ter impacto mediato ou imediato sobre o desenvolvimento infanto-adolescente e b) evidenciam o quanto a participação da vítima é crucial para o sucesso ou não do aliciamento e abuso sexual on-line, de modo que o empoderamento de crianças e adolescentes para agir em sua própria proteção e do envolvimento de atores do SGD torna-se necessário (Cap 2).

\footnotetext{
${ }^{560}$ CURRIE, Vanessa. Relatório do Círculo dos Direitos... p. 54.
} 
O modelo e a metodologia, portanto, apresentam-se como adequados para os fins de prevenção vitimal de violência sexual mediada pela TIC, uma vez que são extremamente úteis como ferramenta de planejamento e ação participativa e integrada.

A utilidade e adequação do modelo/metodologia apresentados, porém, não os tornam imunes a críticas ou impedem propostas de aperfeiçoamento.

Uma das possíveis críticas seria o fato de que a metodologia não permitir um posicionamento crítico do sujeito, pois leva o problema "pronto". Assim, nem sempre a violência sexual mediada pela TIC será importante para um determinado grupo com o qual se trabalha; em algumas realidades, pode haver questões de fundo mais importantes do que o uso da TIC.

Com relação a esta crítica, que é pertinente, identifica-se que o modelo da ecologia social dos direitos da criança e do adolescente (assim como outras abordagens do modelo ecológico de desenvolvimento) permite que o próprio grupo com o qual se trabalha identifique quais as suas prioridades naquele momento.

Outra questão que surge é a promoção do medo do crime, que pode ser facilmente surgir em discussões relacionadas à violência sexual mediada pela TIC. Por ser esta uma questão importante, será discutida em tópico separado, a seguir.

\subsubsection{Medo do crime $x$ consciência do risco}

CÂMARA $^{561}$ identifica a questão do discurso do medo ou da hiperdramatização do crime como relevante nas discussões a respeito de políticas criminais centradas na vítima. O perigo de utilização desse discurso salienta-se sobremaneira quando se fala a respeito de violência sexual contra crianças e adolescentes mediada pela TIC, já que, como já se viu, há verdadeiro pânico ao redor da figura do "pedófilo", pânico este que é estimulado pela mídia.

Para CÂMARA, os tempos atuais são de "democratização da insegurança", sendo o que o medo do crime se deve, em grande parte, à “crescente percepção dos riscos difusos

${ }^{561}$ CÂMARA, op cit. p. 223- 
descendentes das novas formas de manifestação delitiva. (...) Para a comunidade do medo, a ordem do dia encontra-se centrada na necessidade imperiosa de diminuição do sentimento de medo do crime, ou seja, o medo da vítima potencial (virtual) em convolar-se em vítima real". ${ }^{562}$ [itálico no original]

$\mathrm{O}$ autor aponta ainda para a diferenciação possível entre o medo do crime e a percepção do risco, sendo esta uma apreciação cognitiva e aquele uma experiência psicológica com forte carga emocional, havendo, porém, inegáveis conexões entre os dois fenômenos: o medo do crime é fortemente modelado pela percepção do risco; ou seja, não havendo consciência do risco, não há medo do crime; em compensação, acrescento, o "tamanho" do medo do crime não é diretamente proporcional ao risco real de vitimização.

O papel da mídia é um forte componente da equação que transforma o risco real de vitimização em medo do crime. $\mathrm{Na}$ sociedade em rede, as notícias se multiplicam com uma velocidade espantosa, e em poucos minutos uma mesma notícia é "tuitada" e reproduzida centenas de vezes em portais de notícias e redes sociais on-line e na mídia tradicional (TV) a ponto de, no dia seguinte, o grande acontecimento do dia anterior já parecer "notícia velha".

Apesar de citar a existência de pesquisas comprovando "notável sobrestimação do risco de vitimização" em determinados países, comparado ao real risco de vitimização, atribuindo-se tal fato a uma "distorção perceptiva relativamente à realidade delitiva, em muito devedora da intensidade com que a mídia (atráves da Internet, inclusive), veicula o crime" ${ }^{563, " ~ C A ̂ M A R A ~ a d m i t e ~ q u e ~ e ́ ~ c o n t r a d i t o ́ r i a, ~ n a ~ d o u t r i n a ~ e s p e c i a l i z a d a, ~ a ~ d i s c u s s a ̃ o ~ a ~}$ respeito da influência da mídia sobre o despertar do medo do crime.

Sabendo que a questão é complexa e controvertida, e não sendo possível aqui adentrá-la com a profundidade necessária, adoto a posição de LANDINI, que se debruçou sobre a construção da figura do pedófilo na mídia impressa: "existe sim uma relação entre o que é noticiado e o que acontece na realidade, relação essa que, entretanto, não significa uma correspondência direta entre os dois fatores, ou seja, a mídia não é um retrato da realidade, mas, ao noticiar certos fatos e colocar ênfase em alguns aspectos em detrimento

\footnotetext{
${ }^{562}$ Idem, ibidem, p. 226-227.

${ }^{563}$ Idem, ibidem, p. 237-238.
} 
de outros, a mídia estabelece um recorte significativo não apenas porque contém fragmentos dessa realidade, mas também porque ajuda a criar um sentido, atribuir uma importância aos fatos que estão sendo noticiados. (...) Em se tratando de violência sexual, o estudo da mídia é ainda mais importante em se considerando o fato de que, sendo um tipo de violência que ocorre na maioria das vezes em ambientes privados, é conhecida pelo público por meio do que dela se fala“6564

Assim, ao mesmo tempo em que a mídia recorta a realidade, escolhendo os fatos a noticiar, ela também reflete as preocupações sociais e os próprios acontecimentos. E, como dito acima, muito embora o conceito de violência sexual contra crianças e adolescentes tenha sido construído ao longo do tempo, o problema é real, assim como suas vítimas potenciais.

Interesso-me, aqui, por uma questão um pouco mais prática: o cuidado que se deve ter, ao abordar a questão do medo do crime em discussões a respeito de prevenção. A pertinência da preocupação se dá porque, ao mesmo tempo em que programas de prevenção podem alertar para o problema de modo "saudável", podem também ser coadjuvantes em situações de medo do crime, ajudando a aumentá-lo, aumentando o pânico em torno da questão.

É essencial, pois, que as questões referenciadas no Capítulo 2, como os conceitos de violência sexual (gênero e espécies) e, especialmente, os conceitos e preconceitos a respeito de atores envolvidos na (com a) violência sexual contra crianças e adolescentes sejam debatidas ao se falar em prevenção. Evidente que a profundidade do debate deverá ser adequada a cada grupo envolvido, havendo situações em que, aliás, a discussão não caberá.

Uma prevenção vitimal comprometida com um paradigma das (inter-) relações sociais não pode deixar de lado esta dimensão do debate, sob o risco de alinhar-se a uma cultura punitivista, ao invés de promover atitudes positivas e propositivas de solidariedade.

${ }^{564}$ LANDINI, Pedófilo, quem és?... p.S276. 


\subsubsection{Prevenção primária, secundária e terciária.}

Por fim, uma palavra a respeito dos três níveis em que a literatura ${ }^{565}$, tradicionalmente, identifica a prevenção, e o estado da questão no Brasil.

A prevenção vitimal pode se dar em nível comunitário - é disso que trata a presente pesquisa, de modo geral; sendo chamada de prevenção primária. Trata-se de medidas de esclarecimento geral.

O modelo da ecologia social, identificado, porém, propõe uma prevenção primária que vá além da mera informação, engajando atores do SGD, inclusive crianças e adolescentes, na criação de ações para maior proteção desses sujeitos de direitos em desenvolvimento.

Isso não impede que o mesmo modelo seja utilizado, como de fato o é, para intervenções em nível secundário - junto a grupos de risco ou junto a sujeitos que já sofreram algum tipo de abordagem ou dano - e em nível terciário - junto a crianças e adolescentes que já tenham sofrido abuso sexual/danos (significativos ou não).

Se os programas de prevenção primária, no Brasil, parecem ainda tímidos, os esforços de intervenção têm recebido mais atenção. Além de um telefone para denúncias e orientação (o Disque 100, hoje Disque Direitos Humanos), mas que não se configura, ainda, como uma hot/helpline (que seria um canal realmente voltado a orientações sobre o que e como fazer, e não somente a denúncias; investimentos têm sido feitos no atendimento pós-abuso sexual, notadamente a introdução do chamado depoimento sem medo /sem dano, que visa diminuir a revitimização de crianças e adolescentes abusadas sexualmente, propondo atendimento integrado e centrado no bem-estar da criança ${ }^{566}$.

${ }^{565}$ CAPLAN, Gerald. Princípios de Psiquiatria Preventiva. Rio de Janeiro: Zahar, 1980; SIMON, Riad. Psicologia Clínica Preventiva. Novos Fundamentos. São Paulo: EPU, 1989.; WILLIAMS, Lúcia Cavalcanti de Albuquerque. (Org.); ARAUJO, Eliane A C (Org.) Prevenção do abuso sexual infantil: um enfoque interdisciplinar. Curitiba: Juruá, 2009.; WILlIAMS, L. C. A. (Org.); PADOVANI, Ricardo da Costa (Org.); ARAUJO, Eliane A C (Org.); STELKO-PEREIRA, A. C. (Org.); ORMEÑO, Gabriela Isabel Reyes (Org.); EINSTEIN, E. (Org.). Fortalecendo a Rede de Proteção da Criança e do adolescente. São Carlos: Pedro e João Editores, 2010; p. 47-54.

566 CEZAR, José Antônio Daltoé. Depoimento sem Dano: Uma alternativa para inquirir crianças e adolescentes nos processos judiciais. Porto Alegre: Livraria do Advogado Editora, 2007; GONÇALVES, Itamar Batista. Depoimento sem medo(?):culturas e práticas não revitimizantes. ABMP, Childhood-Brasil. 


\section{CONCLUSÕES ${ }^{567}$}

A violência sexual contra crianças e adolescentes mediada pela TIC (aliciamento e abuso sexual on-line) apresenta-se como um problema conectado com outras questões da sociedade em rede.

Pesquisas realizadas com crianças e adolescentes a respeito dos usos que fazem da TIC demonstram que o uso da tecnologia vem se disseminando entre crianças de todas as classes sociais. O uso da TIC por crianças se inicia mesmo antes da alfabetização (em especial ênfase no uso de jogos), e o uso da internet, por volta dos 07 anos, junto com o momento de alfabetização; nativos digitais têm sido introduzidos à tecnologia, porém, desde os primeiros meses de vida.

A internet e os celulares já são TICs sem as quais muitas pessoas não conseguem imaginar suas vidas. Estas tecnologias já foram incorporadas ao cotidiano de milhares de pessoas, adultos, crianças e adolescentes. A virtualidade tornou-se uma dimensão essencial da nossa realidade.

Estas crianças e adolescentes nasceram e vivem na sociedade em rede, em meio a uma revolução tecnológica caracterizada por uma série de transformações sociais, econômicas e culturais que ocorreram a partir da década de 1970, e que vêm ocorrendo numa velocidade jamais experimentada antes pelo homem e se expandindo globalmente.

Dentro deste contexto, crianças e adolescentes vivenciam as intensas mudanças que as caracterizam como sujeitos em desenvolvimento. Estas mudanças são caracterizadas pela medicina, psicanálise, psicologia do desenvolvimento, sociologia, antropologia e outras ciências/saberes como extremamente complexas e interconectadas: desenvolvimento neurológico, psicológico, cognitivo, social, todos estes aspectos são

Secretaria Especial dos Direitos Humanos da Presidência da República (SEDH) e do Conselho Nacional dos Direitos da Criança e do Adolescente (Conanda). Disponível em http://www.cedeps.com.br/wpcontent/uploads/2009/08/Livro_DepoimentoSemMedo_compact.pdf.

$567 \mathrm{O}$ texto conclusivo é apresentado em forma de ensaio. Busquei, com isso, uma forma de integrar os elementos desenvolvidos ao longo do trabalho de forma mais livre, menos presa a categorias, com a intenção de enfatizar o quanto as temáticas desenvolvidas se entrelaçam e dialogam dialeticamente. Para maior clareza, contudo, palavras-chave que podem ser identificadas com as categorias desenvolvidas em cada capítulo são apresentadas em itálico. 
interdependentes. A lesão (física ou psicológica) a algum desses aspectos pode, portanto, provocar danos de curto, médio ou longo prazo (atuais ou potenciais).

Crescer e adolescer na sociedade em rede, portanto, significa vivenciar os aspectos do desenvolvimento em meio à TIC. As redes sociais, comunicadores e outros locais on-line representam novos locus de socialização para crianças e adolescentes. Interagindo na web 2.0, eles criam suas comunidades pessoais, produzem e compartilham conteúdo e experimentam novas formas de relação com a mídia tradicional.

Crescer e adolescer na sociedade em rede significa aprender a dominar os códigos de comunicação ao mesmo tempo em que se desenvolvem os sensos de identidade, privacidade e intimidade, e ao mesmo tempo em que se aprendem regras morais de respeito e autorrespeito e em que se descobre a sexualidade e se desenvolvem habilidades de socialização. A cultura da TIC abre as portas para uma exposição da intimidade para os quais nem todos estão preparados - muitas vezes, nem mesmo os adultos. A cultura da vaidade, disseminada socialmente e estimulada pela mídia, tem como principais protagonistas crianças e, principalmente, adolescentes.

Se a sociabilidade se dá por meio de comunidades interpessoais (cada indivíduo tem a sua rede) quanto mais exposição, mais sucesso na rede. Crianças e adolescentes, por estarem em desenvolvimento, podem subestimar ou não ter clareza a respeito dessas características da rede, expondo informações, dados pessoais e até mesmo (mais especialmente no caso dos adolescentes), o próprio corpo. A dificuldade de gerenciar a exposição na rede, porém, pode ter resultados imprevistos devido às características de "persistência", "buscabilidade”, "replicabilidade” e "audiências invisíveis" da TIC.

Aliadas a algumas tendências que se costuma observar na adolescência, como a necessidade de afirmação, a busca de grupos ("tribos urbanas"), a descoberta da sexualidade, a busca pelo novo e a contestação do status quo, as características da rede podem levar a resultados e práticas que gerem conflitos como o sexting e o cyberbullying.

Se, na maior parte dos casos, esses conflitos não têm relevância jurídico-penal, podendo ser resolvidos fora do Sistema de Justiça formal, e, se resolvidos adequadamente (ou seja, não causarem danos significativos), serão parte do processo natural de desenvolvimento de crianças e adolescentes. 
Por outro lado podem causar impactos significativos na vida (e no desenvolvimento) dos envolvidos, especialmente se a criança/adolescente sofrer humilhações e violências on-line, potencializadas pela persistência e replicabilidade da rede.

As características da rede e da sociabilidade na sociedade em rede, porém, podem abrir as portas para situações de risco mais sérias, que têm sido consideradas como dignas de atenção jurídico-penal, com potencial de danos graves ao desenvolvimento de crianças e adolescentes, aqui caracterizadas como violência sexual mediada pela TIC (compreendendo o aliciamento e abuso sexual on-line).

A violência sexual mediada pela TIC é parte de um fenômeno mais amplo, que é a violência sexual contra crianças e adolescentes, gênero que engloba espécies abuso sexual (intra e extra familiar) e a exploração sexual (que por sua divide-se em quatro modalidades: pornografia infantil, turismo sexual, tráfico para fins sexuais e prostituição).

A violência sexual "deturpa as relações socioafetivas e culturais entre adultos e crianças/adolescentes (...); confunde, nas crianças e adolescentes violentados, os papéis dos adultos, (...) o que implica a perda de legitimidade e de autoridade do adulto e de seus papéis e funções sociais; (iii) inverte a natureza das relações adulto/criança e adolescente definidas socialmente, tornando-as desumanas em lugar de humanas; desprotetoras em lugar de protetoras; agressivas em lugar de afetivas; individualistas e narcisistas em lugar de solidárias: dominadoras em lugar de democráticas; dependentes em lugar de libertadoras; perversas em lugar de amorosas; desestruturadoras em lugar de socializadoras".

A violência sexual transforma crianças e adolescentes em objetos, ferindo não somente a sua liberdade sexual atual ou futura (no caso de adolescentes), mas, principalmente, violando o seu direito ao desenvolvimento saudável, que inclui o desenvolvimento sexual, mas não se limita a ele (já que, como visto, o desenvolvimento de crianças e adolescentes é um processo complexo e integrado), e violando, também, por exemplo, o direito à personalidade (ligado ao desenvolvimento).

A violência sexual, além disso, não precisa ser praticada mediante violência real para se caracterizar como violência, sendo certo que a violência sexual mediada pela TIC, 
ainda que prescinda de contato físico, pode provocar danos significativos ao desenvolvimento de crianças e adolescentes, merecendo atenção jurídico-penal.

A violência sexual mediada pela TIC (aliciamento e abuso on-line) se liga a uma série de outras facetas da violência sexual, como o tráfico para fins de exploração sexual, a pornografia infantil (produção e distribuição), o abuso sexual, a exploração sexual comercial e o turismo sexual.

A dinâmica do aliciamento e do abuso on-line deixam claro que há a necessidade de "cooperação" da vítima desde o início para que haja sucesso no abuso ou no aliciamento. A exposição de dados pessoais na rede e a navegação sem supervisão por responsáveis/educadores pode abrir as portas para a abordagem de um adulto.

A curiosidade de crianças e adolescentes e as características das novas formas de sociabilidade, portanto, pintam o quadro onde pode se desenrolar uma situação favorável ao abuso/aliciamento on-line.

A natural vulnerabilidade que caracteriza o estado de ser criança/ser adolescente se agrava, em muitos casos, pela vulnerabilidade das condições pessoais, sociais, econômicas e culturais de crianças e adolescentes, especialmente daqueles pertencentes às classes sociais mais baixas.

Enquanto os pais de nativos digitais parecem ser capazes de acompanhar mais de perto as atividades de seus filhos na interação com a TIC, utilizando-se de ferramentas como bloqueadores de sites inadequados, além de serem digitalmente letrados, crianças e adolescentes pobres usam as TIC em lanhouses com precária infraestrutura e sem qualquer orientação.

Muitas dessas crianças residem em locais extremamente violentos, sendo que as lanhouses ali localizadas, ao mesmo tempo em que representam locais de socialização centrais em suas vidas, dada a pouca oferta de lazer que é característica das regiões pobres no Brasil, representam também locais onde crianças e adolescentes tornam-se particularmente vulneráveis.

No Brasil (e no mundo), grande parte das respostas que têm sido dadas à violência sexual mediada pela TIC concentram-se, principalmente, na responsabilização de 
ofensores, incentivadas pelos discursos unânimes que unem setores alinhados ao movimento de lei e ordem e à chamada "esquerda punitiva". A luta contra a pedofilia é uma bandeira que não tem partido e mobiliza todos os setores sociais.

Essas respostas reafirmam os estereótipos do crime e do criminoso, igualando todos os atores envolvidos na (com a) violência sexual contra crianças e adolescentes sob a alcunha de "pedófilos", o que não só alimenta o "medo do crime" e as respostas irracionais, como dificulta, inclusive, a adoção de respostas eficazes para os eventuais autores de violência sexual que procurem ajuda médico-psicológica.

Enquanto isso, as características da violência sexual mediada pela TIC demandam, claramente, e urgentemente, respostas preventivas para seu enfrentamento. Mais que isso, demandam estratégias focadas nas vítimas potenciais, chamadas de prevenção vitimal.

Para que a prevenção vitimal seja eficaz, porém, precisa partir da realidade de crianças e adolescentes, já que se relacionam com a TIC de modo diferente dos adultos e vivem momentos de vida também diferentes.

Pensar estratégias de prevenção vitimal focadas em crianças e adolescentes não significa, porém, depositar integralmente em suas mãos a responsabilidade sobre a própria proteção, desresponsabilizando adultos de seu papel. $O$ papel dos adultos no desenvolvimento infanto-adolescente é de extrema importância.

Ao mesmo tempo, ignorar o potencial que crianças e adolescentes têm de participar de modo consciente e responsável é desconsiderar seu status de sujeitos de direitos. Ademais, a centralidade da TIC nas vidas de crianças e adolescentes, e sua condição de sujeitos em desenvolvimento demanda estratégias que sejam adequadas a cada uma das etapas e às suas demais condições de vida (pessoais, econômicas, culturais e sociais).

O modelo da ecologia social dos direitos da criança e do adolescente pode ser uma ferramenta adequada para esta aproximação de prevenção, já que permite identificar todos os atores envolvidos no desenvolvimento da criança e do adolescente, e engajá-los na identificação de fatores de risco e fatores de proteção. 
O modelo é adequado à realidade brasileira e seu Sistema de Garantia de Direitos. Porém, peca por deixar de lado as problematizações a respeito do crime e do criminoso. No trabalho de prevenção vitimal primária, porém, esta questão não pode ser deixada de lado, sob o risco de estar-se patrocinando uma estratégia que desumaniza um dos lados participantes da questão. 


\section{BIBLIOGRAFIA}

ABERASTURY, Arminda; KNOBEL, Mauricio. Adolescência Normal: Um enfoque psicanalítico. São Paulo: Artmed, 1981. 96 p.

ABRAMO, Helena Wendel. Considerações sobre a tematização social da juventude no Brasil. Revista Brasileira de Educação. Rio de Janeiro, n. 5-6, p. 25-36, dez., 1997.

ALMEIDA, Renato Souza de. Juventude e Participação: Novas Formas de atuação juvenil na cidade de São Paulo. Dissertação (Mestrado em Ciências Sociais). São Paulo: Pontifícia Universidade Católica de São Paulo, 2009.

ALVAREZ, Marcos César et al. A vítima no processo penal brasileiro: um novo protagonismo no cenário contemporâneo? Revista Brasileira de Ciências Criminais, São Paulo, v. 18, n. 86, p.247-288, set./out. 2010.

AMIN, Andrea Rodrigues. "Dos Direitos Fundamentais", In MACIEL, Kátia Regina Ferreira Lobo Andrade. Curso de Direito da Criança e do Adolescente - Aspectos Teóricos e Práticos - $4^{\text {a }}$ Ed. 2009. Porto Alegre, Lumen Juris; p. 31-65.

Anais do III Congresso Mundial de Enfrentamento da Exploração Sexual de Crianças e Adolescentes. Rio de Janeiro, 2008. Disponível em http://portal.mj.gov.br/sedh/AnaisIIICM.pdf, download em 20/12/2012.

ANCED (Associação Nacional dos Centros de Defesa da Criança e do Adolescente); Fórum DCA (Fórum Nacional Permanente das Entidades Não Governamentais de Defesa dos Direitos da Criança e do Adolescente). Relatório sobre a situação dos direitos da criança e do adolescente no Brasil, 2004. Disponível em http://www.anced.org.br/cyberteca/publicacoes/relatorio-alternativo-cdc2004/Relatorio-Alternativo-2004-e-Recomendacoes.pdf/view.

Análise sobre os direitos da criança e do adolescente no Brasil: relatório preliminar da ANCED. Subsídios para a construção do relatório alternativo da 
sociedade civil ao Comitê dos Direitos da Criança das Nações Unidas. Seção DCI Brasil, 2009.

ANDRADE, Vera Regina Pereira de. Horizonte de projeção da política criminal e crise do sistema penal: utopia abolicionista e medotologia minimalista-garantista. In: FAYET JÚNIOR, Ney; MAYA, André Machado (Org.). Ciências penais: perspectivas e tendências da contemporaneidade. Curitiba: Juruá, 2011. 400 p., 21 cm. ISBN 978-85362-3249-2. p.363-389.

ANIYAR DE CASTRO, Lola. Direitos humanos: delinqüentes e vítimas, todos vítimas. Discursos Sediciosos: crime, direito e sociedade, Rio de Janeiro, 15 e 16, p.187-202, anual. 2007.

ARATANGY, Lidia Rosenberg. Adolescentes Na Era Digital. São Paulo: Benvirá, 2011.

AZEVEDO, Maria Amélia. Consequências psicológicas da vitimização de crianças e adolescentes. In: AZEVEDO, Maria Amélia; GUERRA, Viviane Nogueira de Azevedo. Crianças vitimizadas: a síndrome do pequeno poder. São Paulo: Iglu, 2000. 211 p. ISBN 85-85631-81-3. p.143-167.

BARATTA, Alessandro. Criminologia crítica e crítica do direito penal: introdução à sociologia do direito penal. Trad. Juarez Cirino dos Santos. 3. ed. Rio de Janeiro: Editora Revan: Instituto Carioca de Criminologia, 2002. (Coleção Pensamento Criminológico, 1).

. Defesa dos direitos humanos e política criminal. Discursos Sediciosos: crime, direito e sociedade, Rio de Janeiro, v. 2, n. 3, p.57-69, 1997.

BARBOSA, Gabriella Ferrarese. Formas de prevenir a violência sexual contra a criança na escola - um olhar da psicanálise e da saúde pública. Dissertação (Mestrado em Saúde Pública) - Universidade Veiga de Almeida. Rio de Janeiro, 2008.

BENEDETTI, Juliana Cardoso. A Justiça Restaurativa em face da Criminologia da Reação Social. In: SLAKMON, Catherine; MACHADO, Maíra Rocha; BOTTINI, Pierpaolo Cruz. (Org.). Novas Direções na Governança da Justiça e da Segurança. Brasília: Ministério da Justiça - Secretaria da Reforma do Judiciário, 2006. 
BERGAMO, Giuliana. Meninas que beijam meninas. Revista Veja, ed 1844, 10 de março de 2004. Disponível em http://veja.abril.com.br/100304/p_088.html, consulta em 10/12/2011.

BERISTAIN IPIÑA, Antonio. A vitimologia criadora de novos direitos humanos. Fascículos de Ciências Penais, Porto Alegre, v. 5, n. 4, p.3-24, out./dez. 1992.

. Desde la victimología hacia la reforma del Código Penal. Cuadernos de Política Criminal, Madrid, n. 54, p.901-913, 1994.

. Los grupos vulnerables: su dignidad preeminente, victimal. In: ANDRADE, Manuel da Costa; ANTUNES, Maria João; SOUSA, Susana Aires de (Org.). Estudos em homenagem ao Prof. Doutor Jorge Dias de Figueiredo Dias. Coimbra: Coimbra Editora, 2009. 1.376 p., 22 cm. (Studia Iuridica; v. 100. Ad Honorem; 5). ISBN 978972-32-1793-3. p.1223-1272.

BITENCOURT, Cezar Roberto. Tratado de Direito Penal. Vol 3. Parte especial. 7. ed. São Paulo: Saraiva, 2011.

BITTENCOURT, Edgard de MOURA. Vítima. $3^{\circ}$ Edição. São Paulo: Universitária de Direito, 1987.

BOYD, Danah. Why Youth love Social Network Sites: The Role of Networked Publics in Teenage Social Life. Youth, Identity, and Digital Media. Edited by David Buckingham. The John D. and Catherine T. MacArthur Foundation Series on Digital Media and Learning. Cambridge, MA: The MIT Press, 2008. 119-142. doi: 10.1162/dmal.9780262524834.119.

BOITEUX, Luciana. Crimes informáticos: reflexões sobre política criminal inseridas no contexto internacional atual. Revista Brasileira de Ciências Criminais, São Paulo, v. 12, n. 47, p.146-187, mar./abr. 2004.

BRASIL. Lei no 8069 de 13/jul/1990. Dispõe sobre o Estatuto da Criança e do Adolescente, e dá outras providências. Disponível em http://www.planalto.gov.br/ccivil/LEIS/L8069.htm 
Presidência da República. Secretaria de Direitos Humanos. PLANO Nacional de Enfrentamento da Violência Sexual Infanto- Juvenil. 3 ed. Brasília: SEDH/DCA, 2002. 59 p. (Série Subsídios, 5).

- Presidência da República. Secretaria de Direitos Humanos. Conselho Nacional dos Direitos da Criança e do Adolescente. Resolução no- 149, de 26 de maio de 2011. Dispõe sobre a participação de crianças e adolescentes nas comissões organizadoras da IX Conferência Nacional dos Direitos da Criança e do Adolescente, nas Conferências Estaduais, Distrital e Municipais. Disponível em http://www.direitosdacrianca.org.br/destaques/9a-conferencia/resolucao-no-149-de26-de-maio-de-2011, Consulta em 19.01.2012.

Presidência da República. Secretaria de Direitos Humanos. Conselho Nacional dos Direitos da Criança e do Adolescente. Resolução ${ }^{\circ}{ }^{\circ}$ 119, de 11 de dezembro de 2006. Dispõe sobre o Sistema Nacional de Atendimento Socioeducativo e dá outras providências.

Disponível

em

http://www.direitoshumanos.gov.br/clientes/sedh/sedh/.arquivos/.spdca/.arqcon/119res ol.pdf, Consulta em 19.01.2012.

Presidência da República. Secretaria de Direitos Humanos. Conselho Nacional dos Direitos da Criança e do Adolescente. Resolução 113, 19 de abril de 2006: Dispõe sobre os parâmetros para a institucionalização e fortalecimento do Sistema de Garantia dos Direitos da Criança e do Adolescente. Disponível em http://www.direitoshumanos.gov.br/clientes/sedh/sedh/.arquivos/.spdca/.arqcon/113res ol.pdf; Consulta 19.01.2012.

Presidência da República. Secretaria de Direitos Humanos. Conselho Nacional dos Direitos da Criança e do Adolescente. Construindo a Política Nacional dos Direitos Humanos de Crianças e Adolescentes e o Plano Decenal dos Direitos Humanos de Crianças e Adolescentes 2011 - 2020: Documento Preliminar para Consulta Pública. $\quad$ Brasília, 2010. Disponível em http://portal.mj.gov.br/sedh/conanda/Politica\%20e\%20Plano\%20Decenal\%20consulta \%20publica\%2013\%20de\%20outubro.pdf. 
Presidência da República. Secretaria de Direitos Humanos. Conselho Nacional dos Direitos da Criança e do Adolescente. Plano Decenal dos Direitos Humanos de Crianças e Adolescentes. Aprovado em 19 de abril de 2011. Disponível em http://www.direitosdacrianca.org.br/midiateca/publicacoes/plano-decenal-dos-direitoshumanos-de-criancas-e-adolescentes/at downloadfile/arquivo.

BRASIL. SENADO FEDERAL. CPI da Pedofilia na Internet. Relatório final. Brasília, $\begin{array}{llll}\text { Senado } & \text { Federal, } & 2010 . & \text { Disponível em }\end{array}$ http://www.senado.gov.br/atividade/materia/getPDF.asp?t=85380\&tp=1. Download em 17/12/2010.

BRASIL. CONGRESSO NACIONAL. CPMI da Exploração Sexual. Relatório Final. Brasília, Congresso Nacional, 2004.

BUENO ARÚS, Francisco. Victimología infantil: tipología : formas de maltrato: ñinos víctimas de agresión sexual. Eguzkilore: Cuaderno del Instituto Vasco de Criminología, San Sebastian, n. 13, p.41-51, dez. 1999.

CALIL STAMATO, Maria Izabel. Protagonismo Juvenil: uma práxis sócio-histórica de ressignificação da juventude. Tese (Doutorado em Psicologia Social). São Paulo, Pontifícia Universidade Católica de São Paulo: 2008.

CÂMARA, Guilherme Costa. Programa de política criminal: orientado para a vítima de crime. São Paulo: Revista dos Tribunais / Coimbra Ed., 2008. 393 p.

CAMPANHA Nacional de Prevenção à Pedofilia na Internet. Disponível em: http://www.censura.com.br/index.php?option=com_weblinks\&catid=2\&Itemid=23

CAMPOS, Marcelo da Silveira. Crime e Congresso Nacional: uma análise da política criminal aprovada de 1989 a 2006. São Paulo: IBCCRIM, 2010. (Monografias, 57).

CANHONI, Vera. Uma questão de imagem. Revista Viver Mente \& Cérebro, O Olhar Adolescente, Vol. 4 - Espelhos da Sociedade. São Paulo: Duetto, p.39-47.

CAPLAN, Gerald. Princípios de Psiquiatria Preventiva. Rio de Janeiro: Zahar, 1980. 
CARTILHA Tirando as vendas. Disponível em: http://www.mscontraapedofilia.ufms.br/index.php?url=ShowPicture.php\%3Fid\%3D53 $9 \&$ target $=1$

CASTELLS, Manuel. A Era da Informação: economia, sociedade e cultura, vol. 1 (A Sociedade em rede). 14ạ reimpressão. São Paulo: Paz e Terra, 1999.

- A Era da Informação: economia, sociedade e cultura, vol. 2 (O Poder da Identidade), São Paulo: Paz e Terra, 1999.

A Era da Informação: economia, sociedade e cultura, vol. 3 (Fim de Milênio), São Paulo: Paz e Terra, 1999.

. A galáxia da Internet: reflexões sobre a Internet, os negócios e a sociedade. Trad. Maria Luiza X. de A. Borges. Rio de Janeiro: Jorge Zahar, 2003. 244 p.

CASTRO, Dagmar Pinto de; ZUQUIM, Judith; NASCIMENTO, Anderson Rafael (Coord). Projeto Grande ABC integrado: crianças e adolescentes em situação de rua: tecendo uma rede de proteção integral do direito à convivência familiar $e$ comunitária. São Bernardo do Campo: Fundação Projeto Travessia: Universidade Metodista de São Paulo, 2009.

CEZAR, José Antônio Daltoé. Depoimento sem Dano: Uma alternativa para inquirir crianças e adolescentes nos processos judiciais. Porto Alegre: Livraria do Advogado Editora, 2007.

CHAUÍ, Marilena. Uma ideologia perversa. Folha de São Paulo, São Paulo, 1999. Disponível em http://www1.folha.uol.com.br/fsp/mais/fs14039904.htm, acesso em 29/12/2011 (disponível somente para assinantes).

CHOO, Kim-Kwang Raymond. Online child grooming: a literature review on the misuse of social networking sites for grooming children for sexual offences Australian Institute of Criminology, 2009. Disponível em http://aic.gov.au/crime_types/cybercrime/prevention.aspx. Consulta em 23/12/2010. 
CINTRA, Elisa Maria de Ulhôa. O despertar da sexualidade. In Revista Viver Mente \& Cérebro, O Olhar Adolescente, Vol. 1 - corpos em transição, p.36-45.

COHEN, Claudio; GOBBETTI, Gisele J. Abuso sexual intrafamiliar. Revista Brasileira de Ciências Criminais, São Paulo, v. 6, n. 24, p.235-243, out./dez. 1998.

COMITÊ Nacional de Enfrentamento à Violência Sexual contra Crianças e Adolescentes. Plano Nacional de Enfrentamento da Violência Sexual Infanto-Juvenil: Uma Política em Movimento. Relatório do Monitoramento 2003-2004.

Centro de Defesa da Criança e do Adolescente da Bahia - Yves de ROUSSAN. Construindo uma história: tecnologia social de enfrentamento à violência sexual contra crianças e adolescentes / Centro de Defesa da Criança e do Adolescente da Bahia - Salvador: CEDECA-BA, 2003. 340p.

COSTA, Antonio Carlos Gomes da. Protagonismo Juvenil: - O que é e como praticá-lo. Disponível em http://escola2000.net/aprendizagem/ac-protagonismo.htm, consulta em $04 / 11 / 11$.

COUNCIL OF EUROPE. Convention on Cybercrime. European Treaty Series - No. 185. Council of Europe. Budapest, 23.XI.2001. Disponível no site: http://www.conventions.coe.int/Treaty/Commun/QueVoulezVous.asp?NT=185\&CM $=8 \& D F=1 / 19 / 2007 \& C L=E N G$ Data do download: 04/01/2011.

Declaration of the Committee of Ministers on protecting the dignity, security and privacy of children on the Internet. The Committee of Ministers of the Council of Europe. 2008.2 Disponível no site: https://wcd.coe.int/wcd/ViewDoc.jsp?id=1252427\&Site=CM\&BackColorInternet=C3 C3C3\&BackColorIntranet=EDB021\&BackColorLogged=F5D383. (Data do download 04/01/2011).

- Guidelines for the cooperation between law enforcement and internet service providers against cybercrimes. Economic Crime Division Directorate General of Human Rights and Legal Affairs. Strasbourg, France. 2 April 2008. Disponível no site: www.coe.int/cybercrime. 
CURRIE, Vanessa. Relatório do Círculo dos Direitos - CPP Brasil: Exploração Sexual Infantojuvenil facilitada pela TIC: uma Análise a Partir das Realidades Vividas de Crianças e Adolescentes. Tradução: Viviane Fontoura; Coordenação e Revisão Técnica da edição brasileira: Maria Emilia Accioli Nobre Bretan. Victoria/BC: International Institute for Child Rights and Development, 2011 (no prelo; versão em inglês disponível em http://childprotectionpartnership.org/resources/recommended/child-ledsolutions/exploring-ict-enabled-child-sexual-exploitation-through-li). Série de Manuais do Círculo dos Direitos da CPP: Planejamento Reflexivo para Mudança Social. Tradução: Viviane Fontoura; Coordenação e Revisão Técnica da edição brasileira: Maria Emilia Accioli Nobre Bretan. Victoria/BC: International Institute for Child Rights and Development, 2011. (no prelo).

CURY, Munir (coord.). Estatuto da Criança e do Adolescente Comentado: Comentários

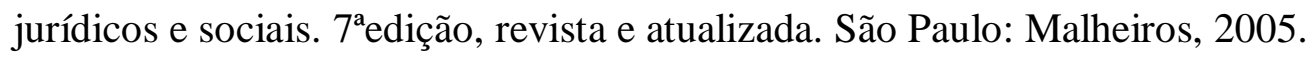

Declaration and Agenda for Action; 1st World Congress against Commercial Sexual Exploitation of Children. Stockholm, Sweden, 27 - 31 August. Disponível em http://www.csecworldcongress.org/PDF/en/Stockholm/Outome_documents/Stockholm \%20Declaration\%201996_EN.pdf, consulta em 05/01/2012.

DEL PRIORE, Mary. (org.). História das Crianças no Brasil. São Paulo: Contexto, 2006.

DIAS, Jorge de Figueiredo, ANDRADE, Manuel da Costa. Criminologia: o homem delinqüente e a sociedade criminógena. $2^{\mathrm{a}}$ reimpressão. Coimbra: Coimbra Editora, 1997.

DIAS, Maria Clarice. $O$ ECA no Brasil; Região Centro-Oeste, Disponível em http://www.promenino.org.br/Ferramentas/Conteudo/tabid/77/ConteudoId/e7df9015f52b-4b33-aec4-b9fc5e0a7dae/Default.aspx

DOS SANTOS, Benedito Rodrigues. Entrevista para Rede Andi Brasil. Disponível em http://10anos.redeandibrasil.org.br/o-livro/bibliografia/entrevista_benedito-dossantos/at_download/file, consulta em 10/11/2011. 
O enfrentamento da exploração sexual infanto-juvenil: uma análise de situação. Goiânia: Cânone Editorial, 2007.

; ARAÚJO, Rogério. O enfrentamento da exploração sexual infantojuvenil: metodologia de trabalho e intervenção. Goiânia: Cânone Editorial, 2009.

; ESBER, Karen Michel; SANTOS, Izabela Barbosa C. Autores de Violência Sexual contra Crianças e Adolescentes: Responsabilização e Atendimento Psicoterapêutico. Goiânia, Cânone Editorial, 2009.

; GONÇALVES, Itamar Batista. Depoimento sem medo(?):culturas e práticas não revitimizantes. ABMP, Childhood-Brasil. Secretaria Especial dos Direitos Humanos da Presidência da República (SEDH) e do Conselho Nacional dos Direitos da Criança e do Adolescente (Conanda). Disponível em http://www.cedeps.com.br/wpcontent/uploads/2009/08/Livro_DepoimentoSemMedo_compact.pdf

; IPPOLITO, Rita; NEUMANN, Marcelo (orgs). Guia Escolar: métodos para identificação de sinais de abuso e exploração sexual de crianças e adolescentes. Brasília: Presidência da República, Secretaria Especial dos Direitos Humanos, 2004.

EDUCAREDE - Dicas de Uso Seguro das Telas Digitais. Livreto disponível em: www.educarede.org.br/educa/img conteudo/livreto.pdf

The Yokohama Global Commitment, disponível em http://www.unicef.org/events/yokohama/outcome.html, consulta em 05/01/2012.

ENDO, Paulo. Criação e Destruição. In Revista Viver Mente \& Cérebro, O Olhar Adolescente, Vol. 4 - Espelhos da Sociedade. São Paulo: Duetto. p. 62-69.

Enhancing Child Safety \& Online Technologies: Final Report of the Internet Safety Technical Task Force to the Multi-State Working Group on Social Networking of State Attorneys General of the United States. the Berkman Center for Internet \& Society at Harvard University, December 31, 2008

ESBER, Karen Michel. Autores de Violência Sexual Contra Crianças e Adolescentes. Goiânia, Cânone Editorial, 2009. 
Escola da Ponte. Projeto Educativo. Disponível em http://www.escoladaponte.com.pt/documen/concursos/projecto.pdf.

ESTEFAM, André. Crimes Sexuais: Comentários à Lei n. 12.015/2009. São Paulo: Saraiva, 2009.

FALEIROS, Eva T. Silveira; RADICCHI, Lis Celia Arantes. Pedofilia: Adoecimento e crime. Revista Juridica Consulex. Brasilia, v.14, n.315, p.35-37, fev. 2010.

FAlEIROS, V. P. e FALEIROS, E. T. S.(coords.). Circuito e Curto- Circuitos: atendimento, defesa e responsabilização do abuso sexual contra crianças e adolescentes no Distrito Federal. CECRIA, São Paulo, Veras Editora, 2006.

FERRETTI, Celso J.; ZIBAS, Dagmar M. L.; TARTUCE, Gisela Lobo B. P. Protagonismo juvenil na literatura especializada e na reforma do ensino médio. Cadernos de Pesquisa, v. 34, n. 122, p. 411-423, maio/ago. 2004, disponível em http://www.scielo.br/pdf/cp/v34n122/22511.pdf, consulta 06/11/2011.

FIGUEIREDO, Elizabeth. Globalização e vitimologia. In: KOSOVSKI, Ester; SÉGUIN, Elida (Coords.). Temas de vitimologia. Rio de Janeiro: Lumen Juris, 2000. 171 p. ISBN 85-7387-133-4. p.27-33.

FONSECA, Magna de Carvalho. Letramento Digital: uma possibilidade de inclusão social através da utilização de software livre e da educação à a distância. Monografia (curso de Pós Graduação "Lato Sensu" da Fundação de Apoio ao Ensino, Pesquisa e Extensão - FAEPE da Universidade Federal de Lavras). Lavras, 2005. Disponível em: http://www.ginux.ufla.br/files/mono-MagnaFonseca.pdf. Download em 17 Abr 2011.

FREUD, Sigmund. A Sexualidade Infantil In Obras psicológicas completas de Sigmund Freud: edição standard brasileira, Volume VII. Rio de Janeiro: IMAGO, 2006.

O Ego e o Id In Obras psicológicas completas de Sigmund Freud: edição standard brasileira, Volume XIX. Rio de Janeiro: IMAGO, 2006.

O Mal estar na civilização. Trad de José Otávio de Aguiar Abreu. Rio de Janeiro: Imago, 1997. 
GARCÍA MÉNDEZ, Emilio. Adolescentes e responsabilidade penal: um debate latino americano. Porto Alegre: AJURIS, ESMP, FESDEP, 2000. Disponível em www.abmp.org.br. Acesso em 11/jun/06.

GARCIA PABLOS DE MOLINA, Antônio, GOMES, Luiz Flávio. Criminologia: introdução a seus fundamentos teóricos. Introdução às bases criminológicas da lei 9099/95 - lei dos Juizados Especiais Criminais. Trad. e notas da primeira parte Luiz Flávio Gomes. 2. ed. revista, atualizada e ampliada. São Paulo: Editora Revista dos Tribunais, 1997.

GRECO, Alessandra Orcesi Pedro; RASSI, João Daniel. Crimes contra a dignidade sexual. 2. Ed. São Paulo: Atlas, 2001.

GRECO, Luís. Um Panorama da Teoria da Imputação Objetiva. Rio de Janeiro: Lumen Juris, 2005.

GRINSPUN, Mirian Paura S. Zippin. A razão dos afetos. Revista Viver Mente \& Cérebro, O Olhar Adolescente, Vol. 4 - Espelhos da Sociedade. São Paulo: Duetto, p. 30-37.

GUILHERME DE SOUZA, José. Vitimologia e Violência nos Crimes Sexuais. Sergio A. Fabris Editor, 1998.

GVT - Uso responsável da Internet. Disponível em: http://www.internetresponsavel.com.br/pdf/educandogvt/cartilha gvt criancas.pdf

HERNÁN GUTIÉRREZ, Mariano. La urgencia (y los horizontes) de una política criminal humanista. Revista Brasileira de Ciências Criminais, São Paulo, v. 19, n. 92, p.175215, set./out. 2011.

HERRERA MORENO, Myriam. El niño ante la agresión doméstica: malos tratos y abuso sexual. Cuadernos de Política Criminal, Madrid, n. 54, p.1113-1141, 1994.

HODGKIN, Rachel; NEWELL, Peter. Manual de Aplicación de la Convención sobre Los Derechos del Niño. Edición española enteramente revisada. UNICEF, 2004. Disponível em http://www.unicef.org/spanish/publications/index_5598.html. 
HOUZEL, Suzana Herculano. Novas Equações Cerebrais. In Revista Viver Mente \& Cérebro, O Olhar Adolescente, Vol. 1 - Corpos em transição. São Paulo: Duetto. p. 27-35.

IKEDA, Ana. Autodidatas da tecnologia, crianças ignoram bê-á-bá da segurança online. UOL Tecnologia. 202/08/2010. Disponível em http://tecnologia.uol.com.br/seguranca/ultimas-noticias/2010/08/02/autodidatas-datecnologia-criancas-ignoram-be-a-ba-da-seguranca-online.jhtm, consulta em 04/10/2011.

KARAM, Maria Lúcia. A esquerda punitiva. Discursos Sediciosos: crime, direito e sociedade, Rio de Janeiro, v. 1, n. 1, p.79-92, 1996.

KNOBEL, Maurício, A Síndrome da Adolescência Normal In ABERASTURY, Arminda; KNOBEL, Mauricio. Adolescência Normal: Um enfoque psicanalítico. São Paulo: Artmed, $1981.96 \mathrm{p}$.

KOSOVSKI, Ester. Vitimologia e direitos humanos. In: ZAFFARONI, Eugenio Raúl; KOSOVSKI, Ester (Org.). Estudos em homenagem ao prof. João Marcello de Araujo Junior. Rio de Janeiro: Lumen Juris, 2001. 474 p. ISBN 85-7387-215-2. p.173-186.

Vitimologia e direitos humanos. Revista Brasileira de Ciências Criminais, São Paulo, v. 10, n. 37, p.235-239, jan./mar. 2002.

(Org). Vitimologia: enfoque interdisciplinar. Sociedade Brasileira de Vitimologia - World Society of Victimology - Universidade Federal do Rio de Janeiro: Reproart, 1993.

; MAYR, Eduardo; PIEDADE JR, Heitor. Vitimologia em Debate. Rio de Janeiro: Forense, 1990.

LA TAILlE, Yves de. Formação Ética: do tédio ao respeito de si. Porto Alegre: Artmed, 2009. 
As virtudes segundo os jovens. In LA TAILLE, Yves de; DE STEFANO, Maria Suzana; SHIMIZU, Alessandra de Morais (orgs). Crise de valores ou valores em crise? Porto Alegre: Artmed, 2009, p. 46-69.

. Desenvolvimento do juízo moral. In Viver Mente\&Cérebro. Coleção Memória da Pedagogia. Vol 1 Jean Piaget. p. 76-88.

. Moral e ética: dimensões intelectuais e afetivas. Porto Alegre: Artmed, 2006.

LANCMAN, Valeria A. La pornografía infantil en internet. Ciencias Penales Contemporáneas: Revista de Derecho Penal, Procesal Penal y Criminología, Mendoza, v. 3, 5/6, p.291-319, 2003.

LANDINI, Tatiana Savoia. A pornografia infantil na Internet- uma perspectiva sociológica. In: Renata Maria Coimbra Libório; Sônia Margarida Gomes Souza. (Org.). A exploração sexual de crianças e adolescentes no Brasil. São Paulo: Casa do Psicólogo, 2004, v., p. 165-182.

- Horror, Honra e Direitos: violência sexual contra crianças e adolescentes no século XX. Tese (Doutorado em Sociologia). São Paulo: Universidade de São Paulo, 2005.

Pedófilo, quem és? A pedofilia na mídia impressa. Cadernos de Saúde Pública (FIOCRUZ), Rio de Janeiro, v. 19, n. supl. 2, p. S273-S282, 2003. Disponível em http://www.scielo.br/pdf/csp/v19s2/a09v19s2.pdf

Pornografia infantil na Internet: violência sexual ou pornografia? Plural (USP), Sao Paulo, v. 7, p. 39-60, 2000. Disponível em http://www.fflch.usp.br/ds/plural/edicoes/07/artigo 3 Plural 7.pdf

LANG, Susan S. Urie Bronfenbrenner, father of Head Start program and pre-eminent 'human ecologist,' dies at age 88. Cornell University News Service, Sept. 26, 2005. Disponivel em http://www.news.cornell.edu/stories/Sept05/Bronfenbrenner.ssl.html, consulta em 15.03.2012. 
LANSDOWN, Gerison. Promoting Children's Participation In Democratic DecisionMaking. UNICEF/Innocenti Research Centre: Florence, 2001.

LARRAURI PIJOAN, Elena. Victimología. In: MAIER, Julio B. J. De los delitos y de las víctimas. Buenos Aires: Ad-Hoc, 2001. 316 p. ISBN 950-9606-44-8. p.281-316.

. Victimología: quienes son las victimas?, cuales sus derechos?, cuales sus necesidades? In: BUSTOS RAMÍREZ, Juan; LARRAURI PIJOAN, Elena. Victimología: presente y futuro : hacia un sistema penal de alternativas. 1. ed. Barcelona: PPU, 1993. 128 p. (IURA). ISBN 84-477-0200-6. p.77-123.

LENHART, Amanda. Teens and Sexting. Washington DC: Research Center, 2009. Disponível em http://www.pewinternet.org/Reports/2009/Teens-and-Sexting.aspx, consulta em 07/02/2012.

LEVICK, Marsha; MOON, Kristina. Prosecuting Sexting as Child Pornography, 44 Val. U. L. Rev. 1035 (2010). Disponível em http://scholar.valpo.edu/vulr/vol44/iss4/2, consulta em 07/02/2012.

LIBÓRIO, Renata Maria Coimbra \& CASTRO, Bernardo Monteiro de. Abuso, exploração sexual e pedofilia: as intrincadas relações entre os conceitos e o enfrentamento da violência sexual contra crianças e adolescentes. In UNGARETTI, Maria America (org.) Criança e Adolescente: Direitos, Sexualidades e Reprodução. São Paulo: Associação Brasileira de Magistrados, Promotores de Justiça e Defensores Públicos da Infância e da Juventude - ABMP, 2010; p 19-41.

\& SOUSA, Sônia M. Gomes (orgs). A Exploração Sexual de Crianças e de Adolescentes no Brasil. Reflexões teóricas, relatos de pesquisas e intervenções psicossociais. São Paulo: Casa do Psicólogo. Goiânia: Universidade Católica de Goiás, 2004.

LIDCHI, Victoria Gabrielle. Fatores de Risco e de Proteção: modelo ecológico do abuso de crianças e adolescentes. In WILLIAMS, L. C. A. (Org.); PADOVANI, Ricardo da Costa (Org.); ARAUJO, Eliane A C (Org.); STELKO-PEREIRA, A. C. (Org.); ORMEÑO, Gabriela Isabel Reyes (Org.); EINSTEIN, E. (Org.). Fortalecendo a Rede 
de Proteção da Criança e do adolescente. São Carlos: Pedro e João Editores, 2010; p. 47-54.

Panorama Internacional e a posição do Brasil no enfrentamento e prevenção do abuso sexual infantil. In WILLIAMS, Lúcia Cavalcanti de Albuquerque. (Org.); ARAUJO, Eliane A C (Org.) Prevenção do abuso sexual infantil: um enfoque interdisciplinar. Curitiba: Juruá, 2009; p. 41-56.

LONGO, Isis. Entrevista ao De Olho no Plano, 19 de julho de 2011. Disponível: http://www.acaoeducativa.org.br/deolhonoplano/not0045.html

LOWENKRON, Laura. Abuso sexual infantil, exploração sexual de crianças, pedofilia: diferentes nomes, diferentes problemas? Sexualidad, Salud y Sociedad Revista Latinoamericana n.5 - 2010 - pp.9-29 / ISSN 1984-6487. Disponível em http://www.epublicacoes.uerj.br/index.php/SexualidadSaludySociedad/article/viewArticle/394/804; consulta em 04.12.2010.

MACHADO, Carla; DA AGRA, Cândido. Insegurança e medo do crime: da ruptura da sociabilidade á reprodução da ordem social. Revista Portuguesa de Ciência Criminal, Coimbra, v. 12, n. 1, p.79-101, jan./mar. 2002.

MACHADO, Martha de Toledo. A proteção constitucional de crianças e adolescentes $e$ os direitos humanos. Barueri: Manole, 2003.

. Proibições de excesso e proteção insuficiente no direito penal: a hipótese dos crimes sexuais contra criança e adolescentes. São Paulo: Editora Verbatim, 2008.

MACIEL, Kátia Regina Ferreira Lobo Andrade. Curso de Direito da Criança e do Adolescente- Aspectos Teóricos e Práticos - $4^{\text {a }}$ Ed. 2009. Porto Alegre, Lumen Juris.

MANNA, Thais Dela. "Hormônios em ação" In Revista Viver Mente \& Cérebro, O Olhar Adolescente, Vol. 1 - corpos em transição, p. 18-25.

MARAFIOTI, Luca. El menor abusado: víctima y testigo vulnerable. Revista de Derecho Penal y Procesal Penal, Buenos Aires, n. 11, p.1863-1870, nov. 2010. 
MELO, Eduardo Rezende. Direito e Norma no campo da sexualidade na infância e na adolescência. In UNGARETTI, Maria America (org.). Criança e adolescente: direitos, sexualidades e reprodução. São Paulo; ABMP; 2010; p. 43-59.

MENTE \& CÉREBRO. O encanto e o desafio dos primeiros anos. In Mente \& Cérebro. Edição Especial: O mundo da infância. São Paulo: Duetto, p. 8.

MIGUEL QUEREJETA, Luis. Estructura de la personalidad del menor víctima de maltrato: daños psicológicos y lesiones físicas. Eguzkilore: Cuaderno del Instituto Vasco de Criminología, San Sebastian, n. 13, p.53-65, dez. 1999.

MORALES GARCÍA, Óscar. Apuntes de política criminal en el contexto tecnológico: una aproximación a la Convención del Consejo de Europa sobre cyber-crime. In: MORALES GARCÍA, Óscar (Dir.). Delincuencia informática: problemas de responsabilidad. Madrid: Consejo General del Poder Judicial, 2002. 347 p. ISBN 8496228-06-1. p.11-33.

NOGUEIRA NETO, Wanderlino. Por um sistema de promoção e proteção dos direitos humanos de crianças e adolescentes. Revista Serviço Social e Sociedade, ano XXVI, n. 83, Edição Especial Criança e Adolescente, p.5-29. São Paulo: Cortez, 2005.

Por uma Política Nacional de Garantia, Promoção e Proteção dos Direitos Humanos da Criança e do Adolescente In Democracia, direitos humanos e mediação de conflitos: do local ao internacional/Organização Valdênia Brito Monteiro.- Recife: Gajop, 2011, p. 22-75, p. 29.

NUCCI, Guilherme de Souza; MARQUES, Ivan Luís. Os contornos normativos da proteção do vulnerável prescrita pelo Código Penal (arts. 218-A e 218-B, introduzidos pela Lei 12.015/2009). Revista Brasileira de Ciências Criminais, São Paulo, v. 18, n. 86, p.9-35, set./out. 2010.

O processo de revisão do Plano Nacional: Relatório de Acompanhamento 2007-2008. Brasília, 2008.

OLIVEIRA, Ana Sofia Schmidt de. A Vítima e o Direito Penal. São Paulo: RT, 1999. 
OLIVEIRA, Maria Claudia Santos Lopes. Vínculos imaginários. In In Revista Viver Mente \& Cérebro, O Olhar Adolescente, Tempo de Paixões. vol. 2., p20-29; São Paulo: Duetto.

ORGANIZAÇÃO DAS NAÇÕES UNIDAS. Protocolo Facultativo à Convenção sobre os Direitos da Criança relativo à venda de crianças, prostituição e pornografia infantis. Disponível em http://www.unicef.pt/docs/pdf/protocolo_facultativo_venda_de_criancas.pdf, consulta em 14.11.2011.

OZZELLA, Sérgio; AGUIAR, Wanda Maria Junqueira de. "Desmistificando a Concepção de Adolescência". Cadernos de Pesquisa, v. 38, n. 133, p. 97-125, jan./abr. 2008, disponível em http://www.scielo.br/pdf/cp/v38n133/a05v38n133.pdf

PACELLI, Eugenio. Curso de Processo Penal. 16ª edição. São Paulo: Atlas, 2012.

PAULA, Paulo Afonso Garrido de. Direito da criança e do adolescente e tutela jurisdicional diferenciada. São Paulo: RT, 2002.

Pesquisa sobre o uso das tecnologias da informação e da comunicação no Brasil : TIC Crianças $2009=$ Survey on the use of information and communication technologies in Brazil : ICT Kids 2009 / [coordenação executiva e editorial/executive and editorial coordination, Alexandre F. Barbosa ; tradução/translation Karen Brito]. -- São Paulo : Comitê Gestor da Internet no Brasil, 2010. Edição bilíngue: português/inglês. ISBN 978-85-60062-30-0.

Pesquisa sobre o uso de tecnologias de informação e comunicação no Brasil : TIC Crianças 2010 - ICT Kids 2010 : Survey on the use of information and communication technologies in Brazil / [coordenação executiva e editorial/executive and editorial coordination Alexandre F. ; tradução para o inglês / translation into English Karen Brito-Sexton]. - São Paulo : Comitê Gestor da Internet no Brasil, 2012. Disponível em http://www.cetic.br/tic/criancas/2010/index.htm, download em $16 / 01 / 2012$.

Pesquisa sobre o uso das tecnologias de informação e comunicação no Brasil : TIC Domicílios e TIC Empresas $2010=$ Survey on the use of information and 
communication technologies in Brazil : ICT Households and ICT Enterprises 2010 / [coordenação executiva e editorial/ executive and editorial coordination, Alexandre F. Barbosa ; tradução/ translation Karen Brito Sexton]. -- São Paulo : Comitê Gestor da Internet no Brasil, 2011.Edição bilíngue: português/inglês. ISBN 978-85-60062-41-6; download em 04/10/2011.

PIAGET, Jean. O juízo moral na criança. $3^{\text {a }}$ Ed. São Paulo: Summus, 1994.

Problemas de Psicologia Genética. In: Piaget. Traduções de Nathanael C. Caixeiro, Zilda A. Daeir, Celia E.A. Di Pietro. São Paulo: Abril Cultural, 1978. 426p. (Os Pensadores).

PIEDADE JR, Heitor. Vitimologia. São Paulo: Freitas Bastos, 1993, 250p.

PLAN INTERNATIONAL. Because I Am A Girl: the State of the World's Girls 2010. Digital and Urban Frontiers: Girls in a Changing Landscape. London: Plan International, 2010, (tradutor nd), disponível em http://www.plan.org.br/publicacoes/download/adolescentes_brasileiras_mundo_digital .pdf; p. 133.

PUEBLA, María Daniela. Criminología, derechos humanos y trabajo social. Capítulo Criminológico: Revista de las Disciplinas del Control Social, Maracaibo, v. 37, n. 3, p.5-29, jul./set. 2009.

Relatório anual 2009 do 123 alô! A voz da criança e do adolescente. Instituto de Pesquisas Sistêmicas e Desenvolvimento de Redes Sociais - Instituto Noos. Rio de Janeiro, 2010.

Relatório desenvolvido pela Save the Children em nome da Comissão para a Participação de Crianças e Adolescentes (CAPC), Terceiro Congresso Mundial de Enfrentamento da Exploração Sexual de Crianças e Adolescentes, 2008.

REYNA, Valerie F.; FALEY, Frank. Flerte com o perigo. In Revista Viver Mente \& Cérebro, O Olhar Adolescente, Tempo de Paixões. vol. 2.; São Paulo: Duetto. 
RIBEIRO, Catarina; MANITA, Celina. Crianças vítimas de abuso sexual intra-familiar: significados do envolvimento no processo judicial e do papel dos magistrados. Revista do Ministério Público. Lisboa, v. 28, n. 110, p.47-86, jun. 2007.

RICHARD, Bernard. There Ought to be a Law: protecting children's online privacy in the 21st century. A Discussion paper for Canadians by the Working Group of Canadian Privacy Commissioners and Child and Youth Advocates. 2009. Disponível em: http://www.ombudsman.yk.ca/pdf/Children'sOnlinePrivacy-e.pdf

RODRIGUES, José Augusto de Souza. A economia política do medo. Discursos Sediciosos: crime, direito e sociedade, Rio de Janeiro, v. 1, n. 2, p.269-276, 1996.

RODRIGUES, Matheus. Discurso midiático e violência. Boletim IBCCRIM. São Paulo: IBCCRIM, ano 18, n. 217, p. 11-12, dez., 2010.

ROJO GARCÍA, Juan Carlos. La realidad de la pornografía infantil en internet. Revista de Derecho Penal y Criminología, Madrid, n. 9, p.211-251, jan. 2002.

ROTMAN, Edgardo; PEREIRA, André Gonçalo Dias (trad.). O conceito de prevenção do crime. Revista Portuguesa de Ciência Criminal, Coimbra, v. 8, n. 3, p.319-371, jul./set. 1998.

SÁ, Alvino Augusto de. Criminologia Clínica e Execução Penal. Proposta de um modelo de Terceira Geração. Revista dos Tribunais. 2011.

Algumas considerações psicológicas sobre a vítima e a vitimização. In Vitimologia no terceiro milênio. Elida Séguin (coord). Rio de Janeiro: Forense, 2004; p. 11-24.

Algumas Ponderações Acerca da Reintegração Social dos Condenados à Pena Privativa de Liberdade in Criminologia clínica e psicologia criminal. São Paulo: Editora Revista dos Tribunais, 2007. p.141-171.

SABADELL, Ana Lúcia. A problemática dos delitos sexuais numa perspectiva de direito comparado. Revista Brasileira de Ciências Criminais, São Paulo, v. 7, n. 27, p.80-102, jul./set. 1999. 
; DIMOULIS, Dimitrios. Constitucionalidade, moralidade e tratamento penal do aborto com o consentimento da gestante. In: Ingo Wolfgang Sarlet; George Salomão Leite. (Org.). Direitos fundamentais e biotecnologia. São Paulo: Método, 2007, p. 325-349.

SaferNet Brasil. Relatório da Pesquisa Online - Brasil: "Hábitos de Navegação na Internet: será que nossos alunos e educadores navegam com segurança na Internet?". Safernet, $2009 . \quad$ Disponível em http://www.safernet.org.br/site/sites/default/files/RELATORIO\%20PESQUISA\%20E DUCA\%20BR\%202009.pdf. Download em 23/12/2010.

r Cartilha $\quad$ Saferdic@as. em http://www.safernet.org.br/site/sites/default/files/cartilha-site.pdf. Download em $23 / 12 / 2010$

SANICOLA, Lia. O trabalho com redes sociais. Trad. Durval Cordas. São Paulo: Veras Editora, 2008.

SANTOS, Juarez Cirino dos. Política criminal: realidades e ilusões do discurso penal. Discursos Sediciosos: crime, direito e sociedade, Rio de Janeiro, v. 7, n. 12, p.53-57, 2002.

SANZ MULAS, Nieves. Pornografia en internet. Revista Penal, Barcelona, n. 23, p.181202, jan. 2009.

SHECAIRA, Sérgio Salomão. Criminologia. São Paulo: Editora Revista dos Tribunais, 2009.

- Mídia e crime. In: SHECAIRA, Sérgio Salomão. Estudos criminais em homenagem a Evandro Lins e Silva: criminalista do século. São Paulo: Método, 2001. 367 p.. p.353-367.

. Sistema de garantias e o direito penal juvenil. São Paulo: Revista dos Tribunais, 2008. 238 p. . 
SILVA PEREIRA, Tânia da. Direito da Criança e do Adolescente: uma proposta interdisciplinar. Rio de Janeiro: Renovar, 1996.

SILVA SÁNCHEZ, Jesús María. A expansão do direito penal: aspectos da política criminal nas sociedades pós-industriais. São Paulo: Revista dos Tribunais, 2002. 151 p. (As ciências criminais no século XXI; v. 11). ISBN 85-203-2287-5.

SILVA, Célia Nunes et al. Efeitos psicossociais e jurídicos nas vítimas de crimes sexuais. In: Seminário Núcleo de Atendimento a Vítimas de Crimes Violento, NAVCV,5-6º Construção da cidadania: desdobramento dos atendimentos às vítimas de violência; violência, vítima e direitos humanos. São Paulo: NAVCV, 2005-2006.

SIMON, Riad. Psicologia Clínica Preventiva. Novos Fundamentos. São Paulo: EPU, 1989.

SOUSA, Sônia Margarida Gomes e SANTOS, Joseleno Vieira dos. Exploração sexual de crianças e adolescentes: pesquisas com documentos de domínio público, Goiânia, Cânone, 2008.

SPOSITO, Marília Pontes. CARRANO, Paulo César Rodrigues. Juventude e Políticas Públicas no Brasil. Revista Brasileira de Educação, São Paulo, no. 24, p. 16-39, setdez. 2003.

STRASBURGER, Victor C.; WILSON, Barbara J.; JORDAN, Amy B. Crianças, adolescentes e a mídia. $2^{\mathrm{a}}$ ed. Porto Alegre: Penso, 2011.

SUBIJANA ZUNZUNEGUI, Ignacio José. La victimización infantil: menores víctimas de agresión sexual y sistema judicial. Actualidad Penal, Madrid, v. 1, n. 14, p.331$350,2000$.

. La victimología infantil: niños víctimas de agresión sexual y sistema judicial. Eguzkilore: Cuaderno del Instituto Vasco de Criminología, San Sebastian, n. 13, p.6784, dez. 1999.

SYDOW, Spencer Toth. "Pedofilia virtual” e considerações críticas sobre a lei 11.829/08. Revista Liberdades IBCCrim, n 1 - maio - agosto de 2009. 
TAGLE LÓPEZ, Erick Gómez. Los actores sociales en el comercio sexual infantil. Iter Criminis: Revista de ciencias penales, México, n. 7, p.113-134, jul./set. 2003.

THE ONLINE SAFETY AND TECHNOLOGY WORKING GROUP. Youth Safety on a Living Internet. $2010 . \quad$ Deport. Disponível http://www.ntia.doc.gov/reports/2010/OSTWG_Final_Report_060410.pdf

TOGNETTA, Luciene Regina Paulino; VINHA, Telma Pileggi. Valores em crise: o que nos causa indignação? In LA TAILLE, Yves de; DE STEFANO, Maria Suzana; SHIMIZU, Alessandra de Morais (orgs). Crise de valores ou valores em crise? Porto Alegre: Artmed, 2009, p. 15-45.

TOURINHO FILHO, Fernando da Costa. Processo Penal. 32a edição. São Paulo: Saraiva, 2010

UNESCO. Educação: um tesouro a descobrir. Relatório para a UNESCO da Comissão Internacional sobre Educação para o século XXI (destaques). Brasília: UNESCO, 2010. Título original: Learning: the treasure within; report to UNESCO of the International Commission on Education for the Twentyfirst Century (highlights). Paris: $\quad$ UNESCO, $1996 . \quad$ Disponível em http://unesdoc.unesco.org/images/0010/001095/109590por.pdf, consulta em 06/11/11.

UNICEF. A Convenção sobre os Direitos da Criança: Adoptada pela Assembleia Geral nas Nações Unidas em 20 de Novembro de 1989 e ratificada por Portugal em 21 de $\begin{array}{lllll}\text { Setembro } & \text { de } & \text { Disponível em }\end{array}$ http://www.unicef.pt/docs/pdf_publicacoes/convencao_direitos_crianca2004.pdf.

. O direito de ser adolescente: Oportunidade para reduzir vulnerabilidades e superar desigualdades. Brasília: UNICEF, 2011.

UNITED NATIONS. Committee on the Rights of the Child. Convention on the Rights of the Child. General Comment no. 12: The right of the child to be heard. Fifty-first session; Geneva, 25 may-12 june, 2009. Disponível em http://www2.ohchr.org/english/bodies/crc/comments.htm, consulta em 18.01.2012. 
. Committee on the Rights of the Child. Convention on the Rights of the Child. General Comment no. 7: Implementing child rights in early childhood. Fortieth Session; Geneva, 12-30 September 2005. disponível em http://www2.ohchr.org/english/bodies/crc/comments.htm, consulta em 25/11/2011.

Committee on the Rights of the Child. Convention on the Rights of the Child. General Comment no 10. Children's Rights in Juvenile Justice. Forty-fourth session. Geneva, 15 January-2 February 2007, disponível em http://www2.ohchr.org/english/bodies/crc/comments.htm, consulta em 25/11/2011.

URRA, Javier. En el umbral del silencio: abusos sexuales a niños y niñas. Boletín del Ilustre Colegio de Abogados de Madrid, Madrid, n. 19, p.61-88, set. 2001.

VASCONCELOS, Ana Maria Pinheiro (redação); IACOCCA, Michele (ilustração). Navegar com segurança: protegendo seus filhos da pedofilia e da pornografia infantojuvenil na Internet. São Paulo: CENPEC, 2006. Disponível em: http://www.childhood.org.br/wp-content/uploads/2008/11/Navegar-com-Segurança2008-1.pdf

VÁZQUEZ, Marcelo Pablo. La explotación sexual comercial de la niñez y su relación con la red internet. Cuadernos de Doctrina y Jurisprudencia Penal, Buenos Aires, v. 10, 18/19, p.643-692, nov. 2005.

VIANO, Emilio C. The "online" world and cybercrime: a new reality for criminal law and criminology. Direito e Cidadania, Praia, Cabo Verde, v. 9, n. 27, p.29-41, 2008.

VICENTIN, Maria Cristina. A vida em rebelião: historias de jovens em conflito com a lei. Tese (Doutorado em Psicologia Clínica). São Paulo: Pontifícia Universidade Católica de São Paulo, 2002.

Infância e adolescência: uma clínica necessariamente ampliada. Rev. Ter. Ocup. Univ. São Paulo, v. 17, n. 1, p. 10-17, jan./abr. 2006.

WILlIAMS, Lúcia Cavalcanti de Albuquerque. (Org.); ARAUJO, Eliane A C (Org.) Prevenção do abuso sexual infantil: um enfoque interdisciplinar. Curitiba: Juruá, 2009. 
; PADOVANI, Ricardo da Costa (Org.); ARAUJO, Eliane A C (Org.); STELKO-PEREIRA, A. C. (Org.); ORMEÑO, Gabriela Isabel Reyes (Org.); EINSTEIN, E. (Org.). Fortalecendo a Rede de Proteção da Criança e do adolescente. São Carlos: Pedro e João Editores, 2010. 68 p.

WINNICOTT, Donald W. Privação e Delinqüência. Tradução Álvaro Cabral. $3^{\mathrm{a}}$ ed. São Paulo: Martins Fontes, 1999.

ZAFFARONI, Eugenio Raul. Criminologia: aproximación desde um margen. Santa Fe de Bogotá: Editorial Temis, 1998.

_ La globalización y las actuales orientaciones de la política criminal. Direito $e$ Cidadania, Praia, Cabo Verde, v. 3, n. 8, p.71-94, nov./fev. 1999/2000. 


\section{ANEXO - GLOSSÁRIO ${ }^{58}$}

3G - Abreviatura da terceira geração de padrões e tecnologias de telefonia móvel.

Aplicativo - Programa de computador cuja finalidade é facilitar a realização de um trabalho específico.

\section{Baixar software - Ver Download.}

Banda larga - Conexão à Internet com capacidade acima daquela usualmente conseguida em conexão discada via sistema telefônico. Não há uma definição de métrica de banda larga aceita por todos, mas é comum que conexões em banda larga sejam permanentes - e não comutadas, como as conexões discadas. Mede-se a banda em bps (bits por segundo) ou seus múltiplos, Kbps e Mbps. Banda larga, usualmente, compreende conexões com mais de 256 kbps. Porém esse limite é muito variável de país para país e de serviço para serviço. No caso das pesquisas TIC, banda larga refere-se a todas as conexões diferentes da conexão discada. Ver Conexão discada.

Blog - É uma contração da palavra "weblog", usada para descrever uma forma de "diário" na Internet. A maior parte dos blogs é mantida por indivíduos (como os diários no papel) que ali escrevem suas ideias sobre os acontecimentos diários ou outros assuntos de interesse.

Bluetooth - Tecnologia de comunicação sem fio que se utiliza de radiofrequência e permite a intercomunicação de dispositivos próximos, com baixo custo de energia. Bom desempenho em situações em que não há necessidade de alta taxa de transferência.

\section{Browser - ver Navegador}

CD (Compact Disc) - Disco compacto. É um disco óptico com grande capacidade de armazenamento de dados. É amplamente utilizado pela indústria fonográfica para a gravação de músicas.

CGI.br - Comitê Gestor da Internet no Brasil. Criado pela Portaria Interministerial $\mathrm{n}^{\mathrm{o}}$ 147, de 31 de maio de 1995, alterada pelo Decreto Presidencial no 4.829, de 3 de setembro de 2003, para coordenar e integrar todas as iniciativas de serviços Internet no país,

\footnotetext{
${ }^{568}$ Os termos deste glossário foram extraídos da Pesquisa sobre o uso das tecnologias de informação e comunicação no Brasil e modificados, quando necessário, para melhor adequação ao presente trabalho. TIC Domicílios e TIC Empresas $2010=$ Survey on the use of information and communication technologies in Brazil : ICT Households and ICT Enterprises 2010 / [coordenação executiva e editorial/ executive and editorial coordination, Alexandre F. Barbosa ; tradução/ translation Karen Brito Sexton]. -- São Paulo : Comitê Gestor da Internet no Brasil, 2011. p. 553-564
} 
promovendo a qualidade técnica, a inovação e a disseminação dos serviços ofertados (http://www.cgi.br).

Chat - Palavra inglesa que significa "bate-papo" e que se refere aos bate-papos realizados por meio da Internet. Quem está conectado manda mensagens para uma página que é atualizada a cada segundo, sendo possível dialogar pela Internet por meio de texto. Quando se dialoga com outras pessoas dessa maneira, diz-se que se está em um chat ou bate-papo.

Chip - Circuito eletrônico em miniatura que processa informações. Em um computador, o chip do processador realiza cálculos, e o chip da memória armazena dados.

Computador de mesa (desktop, PC) - A grande maioria dos computadores em uso é de mesa. "Desktop" literalmente significa "sobre a mesa", e é o termo usado em inglês para designar o computador pessoal. Geralmente, o computador de mesa é composto por um monitor, que lembra um televisor, com um teclado à frente, um mouse para movimentar o ponteiro na tela e uma caixa metálica onde ficam seus principais componentes eletrônicos.

Computador portátil (laptop, notebook, netbook, tablet) - É um computador compacto e fácil de transportar. Laptop, notebook, netbook e tablet são os tipos mais comuns de computador portátil.

Comunicador instantâneo/instant messenger - Programa de computador que permite o envio e o recebimento de mensagens de texto imediatamente. Normalmente, esses programas incorporam diversos outros recursos, como envio de figuras ou imagens animadas, conversação por áudio e vídeo. Ver Google Talk, MSN e Skype.

Conexão discada - Conexão comutada à Internet realizada por meio de um modem analógico e de uma linha da rede de telefonia fixa, que requer que o modem disque um número telefônico para realizar o acesso.

Conexão via celular - Acesso à Internet sem fio, de longo alcance, que utiliza a transmissão sem fio das redes de telefonia móvel, tais como HSCSD, GPRS, CDMA, GSM, entre outras.

Desktop / PC - Ver Computador de mesa.

Dial-up, conexão - Ver Conexão discada.

Download - É a transferência de arquivos de um computador remoto / site para o computador "local" do usuário. No Brasil, é comum usar o termo "baixar" arquivos com o mesmo sentido que "fazer download". 
DVD (Digital Video Disc) - Disco óptico utilizado para armazenamento de dados, com alta capacidade de armazenamento, muito superior às do $\mathrm{CD}$ e do disquete.

E-learning - Ensino a distância. Cursos de nível técnico, de graduação e de especialização que podem ser realizados por meio da Internet.

Email - É o equivalente a "correio eletrônico". Refere-se a um endereço eletrônico, ou seja, a uma caixa postal para trocar mensagens pela Internet. Normalmente, a fórmula de um endereço de e-mail é "nome" + @ + "nome do domínio". Para enviar mensagens a um determinado usuário, é necessário escrever seu endereço eletrônico.

Facebook - ver Rede social

Filtro - Configuração na conta de e-mail que bloqueia mensagens indesejadas ou não solicitadas. Ver Software anti-spam.

Firewall - Software ou programa utilizado para proteger um computador de acessos não autorizados vindos da Internet.

Fóruns - Ver Listas de discussão / Fóruns.

Fotolog - Forma de diário na Internet em que se divulgam imagens, fotografias e desenhos.

Google Talk - Serviço de mensagens instantâneas desenvolvido pela empresa Google.

Hardware - A parte física, material, do computador. O computador se divide em duas partes: a parte física e palpável, como o mouse, o teclado e o monitor (hardware), e a parte não física, os programas, que são as instruções para qualquer computador funcionar, como os aplicativos do pacote Office (software).

Internet café - Ver Lanhouse.

Lanhouse - Estabelecimento comercial em que é possível pagar para utilizar um computador com acesso à Internet. É comum que esse estabelecimento ofereça também uma série de serviços, como impressão, xerox, digitação, entre outros. No Brasil, a denominação lanhouse é a mais corrente, mas também podem ser chamados de cyber café, ou Internet café.

Laptop - Ver Computador portátil.

LinkedIn - Rede social na Internet, com o objetivo de estimular seus membros a criar novos contatos profissionais.

Listas de discussão / Fóruns - Listas em que grupos de usuários trocam opiniões, comentam e discutem diversos assuntos pertinentes a temas em comum. 
Mecanismo de busca - Ferramenta na Internet que serve para a procura de informações em sites. O mais conhecido atualmente é o Google.

Meme - ideia que se propaga rapidamente pela internet sob a forma de gíria, imagem, vídeo, link, hashtag, palavra ou frase. Ex: quando alguém quer dizer que está solitário, pode utilizar tanto a hashtag \#foreveralone (sozinhoparasempre) quanto uma imagem de um homem chorando, toscamente desenhada (um meme linguístico traduzido em imagem). Normalmente, a origem de um meme na internet é difícil de identificar, pois se espalha muito rapidamente. $\mathrm{O}$ meme é rapidamente incorporado principalmente por meio das redes sociais, e pode ser modificado e adaptado pelos usuários. O termo foi criado em 1976 por Richard Dawkins; é considerado como uma unidade de informação que se multiplica de cérebro em cérebro, ou entre locais onde a informação é armazenada (como livros). O meme é considerado uma unidade de evolução cultural que pode de alguma forma autopropagar-se. (fonte parcial: Wikipedia: http://pt.wikipedia.org/wiki/Meme)

Mensagem de texto - Mensagem enviada e recebida por telefone móvel. Ver SMS.

Microblog - blog com capacidade de publicação de conteúdo limitada a poucos caracteres. Ver Twitter.

Modem - Equipamento que converte sinais digitais derivados de um computador ou de outro aparelho digital em sinais analógicos para transmiti-los por uma linha tradicional de telefone (fios de cobre trançados), de forma a serem lidos por um computador ou outro aparelho. Seu nome vem da justaposição de mo (modulador) a dem (demodulador).

Mouse - Equipamento para mover o ponteiro na tela do computador, permitindo que o usuário interaja de modo amigável com os programas instalados.

\section{Mozilla Firefox - Ver Navegador.}

MSN (Microsoft Network). Ver Comunicador instantâneo

Navegador/ Browser - Programa que permite ao usuário navegar por páginas na Internet (como portais de notícias, de entretenimento, redes sociais, sites de empresas/governo/pessoais, blogs, lojas on-line etc.

\section{Notebook - Ver Computador portátil.}

On-line - "Em linha". O termo significa que alguém está eletronicamente "disponível” no momento, ou seja, conectado à Internet.

Orkut - Ver Rede social - muito popular entre adolescentes, atualmente, no Brasil.

Página web (webpage/website/site) - Uma página web corresponde a um endereço na web no qual se pode visualizar e navegar por meio de um browser (programas para 
navegação na Internet). É na página web que se encontram as informações, as imagens e os objetos referentes aos conteúdos disponíveis na internet.

\section{PC (Personal Computer) - Ver Computador de mesa.}

Peer-to-peer (P2P) - Tecnologia para criar uma rede virtual de computadores, em que cada máquina pode ser utilizada como servidor para outra máquina, ou como cliente de outra máquina. A tecnologia é utilizada na Internet para troca de arquivos entre usuários, muitas vezes arquivos de música ou vídeo.

Realidade virtual - Técnica avançada de interface em que o usuário pode realizar imersão, navegação e interação em um ambiente sintético gerado por computador, utilizando canais multissensoriais, com o objetivo de criar de forma fidedigna a sensação de realidade.

Rede social - Site que permite a seus membros criar novas amizades e manter relacionamentos; compartilhando conteúdos como músicas, notícias, imagens etc.

Ringtone - Música ou som utilizado como toque de telefone celular.

Second Life - Software desenvolvido pela empresa Linden Labs que simula alguns aspectos da vida real e social do ser humano em um ambiente virtual e tridimensional. Os usuários do software criam personagens para poder interagir com o ambiente virtual, como se ele fosse um ambiente real, com pessoas, casas, carros, etc.

Site/Website - Literalmente, significa "local na rede". Pode-se dizer que é um conjunto de páginas na Internet sobre determinado tema, identificado por um endereço web.

Smartphone - Telefone celular que oferece como uma de suas funcionalidades a possibilidade de acesso à Internet. Por meio desses aparelhos, é possível ler e-mails, navegar por páginas da Internet, tirar fotos, fazer vídeos, subir e baixar músicas, vídeos e fotos, enviar para os amigos, fazer compras e acessar informações de forma geral.

Skype - Software que permite gratuitamente comunicação de voz e imagem pela Internet por meio de conexões on-line.

SMS (Short Message Service) - Serviço de mensagens curtas. É um serviço disponível em telefones celulares que permite o envio de mensagens de texto não muito longas (até 255 caracteres) entre os equipamentos compatíveis com esse serviço.

Software - Qualquer programa de computador. O computador se divide em duas partes: a parte física e palpável (hardware) e a parte não física, os programas, que são as instruções para qualquer computador funcionar (software).

Tablet - Ver Computador portátil. 
TIC (Tecnologia da informação e comunicação) - "expressão geral que inclui qualquer aparelho de comunicação ou sua utilização, abrangendo rádio, televisão, telefones celulares, computadores, equipamentos (hardware) e programas (software) de rede e sistemas de satélite, bem como os diversos serviços e aplicações nos quais são utilizados, como videoconferências, bate-papo on-line, educação à distância etc" ${ }^{, 569}$.

Timeline - linha do tempo. É um recurso de organização de páginas em redes sociais que disponibiliza os conteúdos postados por cada usuário conforme a data/horário/ano em que foram publicados. A sua utilização com maior sucesso foi no Twitter, tendo sido posteriormente adotada por outras redes sociais, como o Facebook.

TV a cabo - Canais de televisão que chegam ao aparelho por meio de um cabo coaxial.

TV digital - Sinal de televisão que chega ao aparelho de forma digital e, portanto, é menos sujeito a degradação por ruído.

Twitter - Rede social de microblogs, onde os usuários podem escrever mensagens de até 140 caracteres. Os usuários são identificados por @ nome_do_usuário e os assuntos podem ser categorizados por hashtags (\#). (www.twitter.com)

Upload - É a transferência de arquivos de um computador "local" do usuário para uma máquina remota / site. No Brasil, é comum usar o termo "subir" arquivos com o mesmo sentido de "fazer upload".

Videoconferência - Comunicação de imagem (vídeo) e voz via Internet.

Viral - Neologismo utilizado para designar uma técnica de marketing, normalmente veiculada em vídeos de curta duração, que se propaga rapidamente pela web, se espalhando na velocidade de um vírus por meio de redes sociais já existentes.

Vírus - Programa malicioso de computador, ou somente parte desse programa de computador, que se propaga infectando, isto é, inserindo cópias de si mesmo e se tornando parte de outros programas e arquivos de um computador. O vírus depende da execução do programa ou arquivo hospedeiro para que possa se tornar ativo e dar continuidade ao processo de infecção.

VoIP (Voice over IP) - Tecnologia que permite a transmissão de sinais de voz por meio da Internet ou de uma rede privada.

Webcam - Câmera de vídeo de baixo custo, muitas vezes integrada ao computador, que capta e transfere imagens de modo quase instantâneo para o computador. É utilizada em

${ }^{569}$ CURRIE, Vanessa. Série de Manuais...; p.154. 
videoconferências, chats on-line via comunicadores instantâneos como Skype, Google Talk e MSN; pode ser utilizada também para gravar vídeos amadores.

Website - Ver Site/Página na Internet.

WiFi (Wireless Fidelity) - Marca licenciada originalmente pela Wi-Fi Alliance para descrever a tecnologia de redes sem fio (WLAN).

WWW (World Wide Web) - É a rede mundial de computadores.

YouTube - Site que permite aos usuários subir, assistir e compartilhar vídeos em formato digital na Internet. (www.youtube.com) 